\title{
Public Water Policies: The Ultimate Weapons of Social Control
}

\author{
By
}

Charles Ray Porter, Jr.

\section{DISSERTATION}

Submitted in Partial Fulfillment of the

Requirements for the Degree of

Doctor of Philosophy in Business and Economics

Universtat Jaume I

Castelló de la Plana, Spain

Supervisors Maria Jesus Muñoz-Torres, Ph.D. and R. Gary Pletcher, Ph.D. 


\section{Table of Contents}

Chapter 1 Introduction 3

Chapter 2 Review of the Literature 34

Chapter 3 The Study's Methodology 39

Chapter 4 "Diplomatic" and "Due Process" Social 55 Control: "Supra-Legal" Authority in Water and Limitations on Sovereignty

Chapter 5 "Due Process" Social Control: Timeliness 94 in Adjudication and Fair Market Valuation in Water

Chapter 6 "Deceptive" and "Destructive" Social 185 Control: Water Policy Used as the Ultimate Weapon

$\begin{array}{ll}\text { Chapter } 7 \text { Conclusion } & 231\end{array}$

Bibliography 233

$\begin{array}{ll}\text { Appendices } & 284\end{array}$ 


\section{Chapter One}

\section{Introduction}

The question is how to manage a resource that is fleeting, crosses national boundaries, and evaporates into the air.

Professor Elli Loukal

Water is the common denominator of all life on Earth. As such, the sustainability of the human-water interface ${ }^{2}$ depends upon fair, transparent, and accepted public water policies in every society today, as well as throughout history. No matter how simple or complex, public water polices are in their basic essence human-envisioned, human-enacted, and humanenforced methods of social control. The three pillars of any society are the environment, the economy, and human relationships. Human relationships are multi-faceted. Water is the common foundation to all three pillars of society; without water none could exist. Human relationships create

\footnotetext{
${ }^{1}$ Elli Louka. Water Law and Policy. (New York, Oxford University Press, 2008) 23.

${ }^{2}$ The "human-water interface" is the place at which humans and water meet and affect each other.
} 
the public water policies that determine how anyone living in community shares the most important and precious natural resource, water. Humans relate to each other, their government, their environment, and their economy. The three pillars of society relate to each other just as the geological containers of water relate to each other conjunctively, or joined together, combined so that changes in one directly results in changes to the other. No public water policy of any kind will be accepted by the people until realizing and respecting the complex conjunctive relationship of the three pillars of society. However, finding an acceptable public water policy among diverse and competing human interests is a formidable challenge. This owes largely to the natural state of water, which is an essentiality of everyday life. As such, the accomplishment of a widely accepted public water policy becomes a difficult task. In addition, setting a public water policy that has a political and regulatory life of some predictability and continuity is difficult because water is a rapidly moving "target." Water is constantly in motion moving through the one hydrological cycle ${ }^{3}$ seeking a way to reach sea

\footnotetext{
${ }^{3}$ According to the United States Geological Survey, the hydrological cycle is defined as: "Earth's water is always in movement, and the natural water cycle, also known as the hydrologic cycle, describes the continuous movement of water on, above, and below the surface of the Earth. Water is always changing states between liquid, vapor, and ice, with these processes happening in the blink of an eye and over millions of years." The USGS offers this definition also in Spanish: "Qué es el ciclo del agua? Fácilmente puedo contestar que...soy
} 
level at all times. Water freely moving about in nature is fugitive, quick to disappear, and is best described as fleeting. Public water policies that allow society to exist in a state of benefit and equilibrium are thus only effective if both environmentally and economically sustainable.

Environmentally sustainable water policies are unique in the sense that they do not manage and allocate water through methods similar to the "mining" of gold or oil. Rather, they do so by balancing use based upon availability and accessibility, which due to the unpredictability of rainfall, is always changing. Water policies must be financially sustainable as well so as to not only pay for or amortize the cost of public water projects but also to adapt to the cycles of the dynamic economy of any region.

Human beings tend to design public policy based upon politically based boundaries but water ignores political boundaries. Professor Elli Louka, author of the highlighted quote beginning this chapter, indicates concern for this by posing a question, "Can a natural resource, like water, that knows no national borders, be managed based on such borders?"4

\footnotetext{
"yo"! El ciclo del agua describe la presencia y el movimiento del agua en la Tierra y sobre ella. El agua de la Tierra esta siempre en movimiento y constantemente cambiando de estado, desde líquido, a vapor, a hielo, y viceversa. El ciclo del agua ha estado ocurriendo por billones de años, y la vida sobre la Tierra depende de él; la Tierra sería un sitio inhóspito si el ciclo del agua no tuviese lugar." http://water.usgs.gov/edu/watercycle.html accessed many times but specifically on May 29, 2016.

${ }^{4}$ Louka. 1.
} 
The obvious answer is no. Public water policy based on manmade borders ignores the natural properties of water and overlooks typical human nature as well. All widely accepted public water policies must consider the natural characteristics of water along with the natural fickle oddities of human political will. Establishing effective management of water resources based on political boundaries requires continuous willing and consistent cooperation between upstreamers and downsteamers, a level of human collegial relationship that history proves is all but impossible to achieve.

In today's world of warming trends and drought coupled with regional population growth either through increased birth rates, longer life spans, refugees fleeing war torn regions, or people immigrating to regions that offer them more hope, the opportunity for powerful upstreamers to exert control over less powerful downstreamers is tempting. Public water policies offer the opportunity for the more powerful to control the less powerful at all levels of human relationships. Sadly for the less powerful in our world, the late Dr. David Weber's 1972 comment still applies all too well, "Water doesn't flow downhill ... it flows towards money."5

\footnotetext{
${ }^{5}$ Dr. David Weber, a dear friend and mentor, Director of the Clements Center for Southwest Studies \& Dedman Professor of History at Southern Methodist University. Money and power are inextricably linked.
} 
Are public water policies the ultimate weapons of social control? This inquiry forms the central research question of this study. This study reveals and analyzes the ways in which public water policies were used as weapons of social control in the past and the ways in which they are being used now. An example of one extreme that has existed for many years and is likely to continue for the near future is Israeli control over the water of the Palestinians living in the "occupied territories." Another extreme is found in an examination of the United States' use of public water policies as weapons of social control in a much more subtle and indirect way. Both extremes are equally as impactful on their respective societies.

A central theme of the answers to the central research question of this study examines Texas and Spain whose relationship in colonial times $^{6}$ was that of mother and child in the management and promulgation of water rights, property rights, and public water policies.

\footnotetext{
${ }^{6}$ I define Spanish Colonial times in the United States as beginning around 1598 with Oñate's crossing of the Rio Grande and continuing until the Spain lost Mexico with the official establishment of the Republic of Mexico in 1824. Spain owned Texas, in my opinion, since the Papal Bull of Alexander the VI issued in 1493 which gave the Spanish the lands in the New World until 1824. Ownership aside, Spain's actual area of true control in the land that comprises today's Texas was limited to only two regions, the land around El Paso and along the San Antonio River from Villa San Fernando (the headwaters of the San Antonio River) to Mission Espiritu Santo and Presidio La Bahia now known as Goliad, Texas.
} 
Spain and Texas still exist in a rarely recognized distant cousin-like relationship and have done so since the $17^{\text {th }}$ century. In fact, from 1840 at the formation of the Republic of Texas prior to Texas' joining the United states continuing even today, the first and most important proof of a right to use surface water in Texas is the original spanish Colonial appropriation. Almost 300 years after spain's first real effort in Texas by the establishment of the short-lived east Texas missions, in 1967, the Texas legislature passed the Water Rights Adjudication Act to settle over one hundred years of dispute over surface water rights. The Act required anyone who claimed a right to use surface water for any use other than domestic and livestock use to prove that claim in Austin through the courts. For once and for all, each surface water right would be determined by the courts of Texas. 7 This adjudication process of surface water rights took almost 30 years to complete. During the entire process, the most significant proof of an individual surface water right was the original Spanish appropriative grant from the King of Spain, the earliest grants of which in Texas dated to the five missions founded at the source of the San Antonio

\footnotetext{
${ }^{7}$ An example of "due process" social control, a new term I propose that I discuss in detail later in this study.
} 
River. The missions claimed their water right from a royal

decree in 1718 .

Few people know that the first official water law policy

in Texas was issued on December 25, 1731 by Viceroy Juan de

Acuña, 8 Marques de Casafuerte. The policy demonstrated the

fairness and justice-based doctrine that the spanish operated

under during the entire time they held Texas, a doctrine that

is honored and echoes today in Texas water law. 9

The friars in the Catholic missions held the land in

Texas for the King of Spain by attempting to convert the

Native Americans to Spanish Catholics who would then

eventually become Spanish citizens. Like every other group of

Spanish settlers, the missionary friars wanted to control as

much precious water as they could to sustain their missions.

A new settler group from the Canary Islands, called Isleños, 10

came to be regarded as a threat to the missionaries' control

of the water resources so precious to them. The missionaries

told to the Viceroy that there was simply not enough water

\footnotetext{
${ }^{8}$ Francisco A. Eissa-Barroso. Early Bourbon Spanish America: Politics and Society in a Forgotten Era (17001759). Leiden, Netherlands, Brill, 2013. Juan de Acuña y Bejarano was born in Lima, Peru in 1658 and died in Mexico City on March 17, 1734. He had a successful military career and served governor of Messina, Sicily. He served as military commander of the kingdoms of Aragon and Mallorca before he became President of the Audiencia of New Spain and Viceroy.

${ }^{9}$ Charles Porter. Spanish Water/Anglo Water. College Station: Texas A \& M University Press, 2009. 52-53. See also Bexar Archives Translations. The Center for American History, The University of Texas at Austin, Series 1, General Manuscripts 1717-1789, Box 2C14, Vol. 2, December 25, 1731 - June 25, 1733.

${ }^{10}$ Porter. Spanish Water. 52. Also see Marion A Habig,. . The Alamo Chain of Missions. Chicago: Franciscan Herald Press, 1968. 124.
} 
for the expanding settlement and that the missions would suffer greatly.11 On December 25, 1731, Viceroy Casafuerte responded to the missionaries. The King wanted his water (the King owned the water and held it in trust for his people) to be shared and used in common by all settlers. The basics of the King's commitment to fairly allocate water among his settlers were implemented from this first recorded dispute. Casafuerte's letter set the legal foundation upon which the fair administration of water would be built for Spanish times in San Antonio and importantly would "set a precedent for later water law and management concepts in Texas and the United States."12

The Viceroy wrote Fray Vergara:

I am having in mind Your Reverence's letter and the writing presented by before Don Juan Antonio Perez de Almazán, captain of the presidio of San Antonio in the province of Texas, of which relate to the resistance and the opposition introduced against the sharing of the waters of the Arroyo and the San Antonio River with the families of the Canary Islands who by order of His Majesty have gone to settle in that. The reasons for this action were set forth by Your Reverence, the principal being that the supply of water scarcely meets the needs of the five missions in making their lands productive.

In view of I must say to Your Reverence that at this time I am sending a dispatch to the said Captain in order that in conformity with its provisions, he shall

divide and distribute the water [emphasis added], giving

\footnotetext{
${ }^{11}$ Ibid. See also Thomas F. Glick,. Southwestern Studies, Monograph No. 35, The Old World Background of The Irrigation System of San Antonio Texas. El Paso: Texas Western Press, 1972. 32.

12 Porter. Spanish Water. 52.
} 
both the missions and the Islander families a share of it; for although it might seem that the legal provisions stated by Your Reverence should be understood and applied solely in favor of the missions, would be of no profit if the cause were lacking around which the difficulty centers, namely that of the water. Moreover, there is a royal law more decisive than all and applicable to the case [emphasis added]. Therefore, since the [water] is sufficient for the use and benefit of all, it is just that its usefulness should be in common [emphasis added], especially when prudent management of its benefits will obviate the injury which Your Reverence points out. By rotating the apportionment of, every interested party being assigned his days [emphasis added], the cause and the dispute shall cease without my giving consideration to the privileges of the reductions should enjoy, since they are not harmed by this measure. It would be a lamentable thing, that after His Majesty has spent a vast sum from His Royal Hacienda in bringing these families here from the Canaries, they should be abandoned and should be left without water which would be the same as having brought them to perish; besides the King appointed them to settle that place.

Thus, harmony and agreement can overcome any difficulty that may be regarded as serious, and when the use of the water has been arranged, as ordered in this dispatch, there will be cooperation and conservation [emphasis added]; and Your Reverence and your missions will not fail to experience many advantageous results from the proximity of the settlement to. I am confidently expecting all to take the most orderly steps so that may take advantage of the water at the proper time and in the proper manner, the families not being excluded. That God may guard Your Reverence, many years is my desire. ${ }^{13}$

This early decree followed the ancient concept in spanish law that water is to be divided and shared among everyone fairly

\footnotetext{
${ }^{13}$ Porter. Spanish Water. 54. See also Bexar Archives Translations. The Center for American History, The University of Texas at Austin, Series 1, General Manuscripts 1717-1789, Box 2C14, Vol. 2, December 25, 1731 - June 25, 1733.
} 
or with justice, derecho.14 Casafuerte decreed that the water was sufficient for the use of all, that it is just (derecho concept appears again), and that the water will be used in common by all the settlers. Diaries written by the early Franciscan visitors to the area in 1709 and 1716 had declared there was ample water for a city. ${ }^{15}$ Casafuerte in the letter carefully supported his ruling in a way in which there can be no doubt his edict was correct and undeniably just.

The key points in this first decree of customary water law in Texas were:

1. The water of the river and the springs was to be divided and distributed and shared;

2. The water was sufficient for all;

3. The water's use shall be in common;

4. The use of the water should be rotated and an assignment of days should be made to the interested parties; and

5. There would be cooperation and conservation of the water.

His ruling on rotation and assignment of days for use of the water and on cooperation with conservation survived into the 20th century in modern Anglo Texas. It delivered the justice and fairness indicative of the Spanish colonial legal system. Today's relationship between Texas and Spain remains cousin-like because Texas continues to legally recognize

\footnotetext{
${ }^{14}$ Later in this study the concept of derecho is explained in great detail.

${ }^{15}$ Ibid. See also Jesús F De la Teja, ed. . Preparing the Way, Preliminary Studies of the Texas Catholic Historical Society, Number 1. Austin: Texas Catholic Historical Society, 1997. 55.
} 


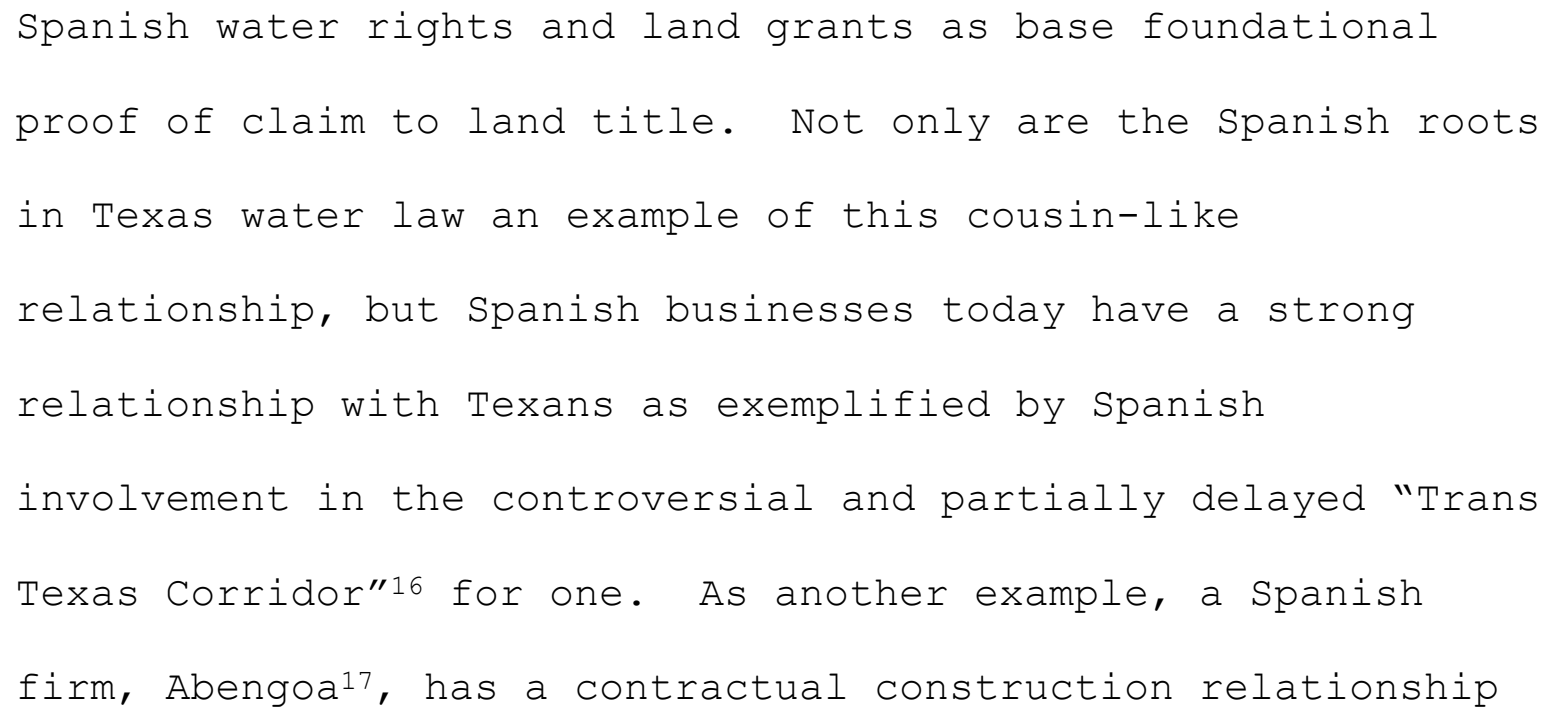

${ }^{16}$ In June 2002 Texas Governor Rick Perry proposed the Trans-Texas Corridor by almost Executive Order to the Chairman of the Texas Department of Transportation. The long term idea was to create wide transportation corridors across Texas by acquiring wide swaths of right of way not only for citizen toll roads, but for commercial and rail transportation as well. A strong outcry of dissent developed across rural Texas in many ways led by author Jerome R. Corsi. According to wnd.com, the self-proclaimed largest Christian website in the world, from a report written on December 29, 2012 by Jerome R. Corsi: "On March 11, 2005, a "Comprehensive Development Agreement" was signed by TxDOT to build the "TTC-35 High Priority Corridor" parallel to Interstate 35 . The contracting party was a limited partnership formed between Cintra Concesiones de Infraestructuras de Transporte, S.A., a publically-listed company headquartered in Spain, majority controlled by the Madrid-based Groupo Ferrovial, and a San Antonio-based construction company, Zachry Construction Corporation. The Cintra deal meant that once the TTC was completed, anyone who wanted to drive on it would have to pay an investment consortium in Spain for the privilege of driving in Texas. Although somewhat incomprehensible to most U.S. citizens, these public-private partnerships involve selling off key U.S. infrastructure projects to foreign entities. Granted, the "ownership" rights of projects like TTC-35 would have remained with the state of Texas, yet selling off the leasing rights amounts in the thinking of most U.S. citizens to selling off the highway to foreign interests for the term of the lease. Under the terms of the TTC agreements with TxDOT, Cintra would have had the rights to operate TTC-35 for 50 years and to collect all tolls on the road in that period of time. The Comprehensive Development Agreement called for Cintra-Zachry to provide private investment of $\$ 6$ billion "to fully design, construct and operate a four-lane, 316-mile toll road between Dallas and San Antonio for up to 50 years as the initial segment of TTC-35. For this, Cintra-Zachry paid the state of Texas $\$ 1.2$ billion for the long-term right to build and operate the initial segment as a toll facility." See http://www.wnd.com/2012/12/its-back-texas-in-super-highway-deal-withspain/\#x0PPFvZJ7ZutLmLC.99. During the 82 ${ }^{\text {nd }}$ Regular Session of the Texas Legislature, House Bill 1201 passed "to repeal of authority for the establishment and operation of the Trans-Texas Corridor." http://www.capitol.state.tx.us/BillLookup/History.aspx?LegSess=82R\&Bill=HB1201. Although I heard many complaints about Spanish companies being involved in Texas projects from students in the continuing education credit courses I authored for the Texas Real Estate Commission, Farm and Ranch for Texas Agents, TREC course \#07-00-084-24796 and Water Rights for Texas Agents, TREC course \#004-00-064-24518, I think the real problem people had with the corridor was not Spain's involvement per se, but the huge amounts of farm and ranch land that the state of Texas would take by condemnation.

${ }^{17}$ Abengoa S.A. is a Spanish multinational corporation, which includes companies in the domains of energy, telecommunications, transportation, and the environment. Founded in 1941, it is headquartered in Sevilla. See http://www.abengoa.com/web/en/compania/nuestra_historia/ for the history of the company. Abengoa recently filed for bankruptcy throwing the Vista Ridge Pipeline project into disarray. 
with the Vista Ridge water pipeline project. They are involved in moving groundwater leased or purchased from 3,400 landowners in Burleson and Lee counties in central Texas to San Antonio, a city that has grown over 300 years since the earliest Spanish settlers arrived to become the $7^{\text {th }}$ largest city in the United States.

Not only do Texas and Spain have long term legal and water management relationships through shared water policy concepts, but their climate and geography is so very similar that my visits to spain confirmed for me the view of the Franciscan missionaries of the 16th, 17th, and $18^{\text {th }}$ centuries Texas felt like home to them. Spain felt like home to me on my visits - Spain seemed like Texas with higher mountains and millions more olive trees but with the same wonderful people and a very similar climate.

Both Spain and Texas share similar problems in public water policy, drought prone climates, agricultural businesses dependent upon irrigation, and vibrant thirsty cities demanding water for survival. Both governments have confusing and fragmented public water policies that the bulk of their citizenry neither understand nor support. Couple this citizen attitude with the expanding and developing claims of the United States federal government and the European Union, and both Texas and Spain are struggling with 


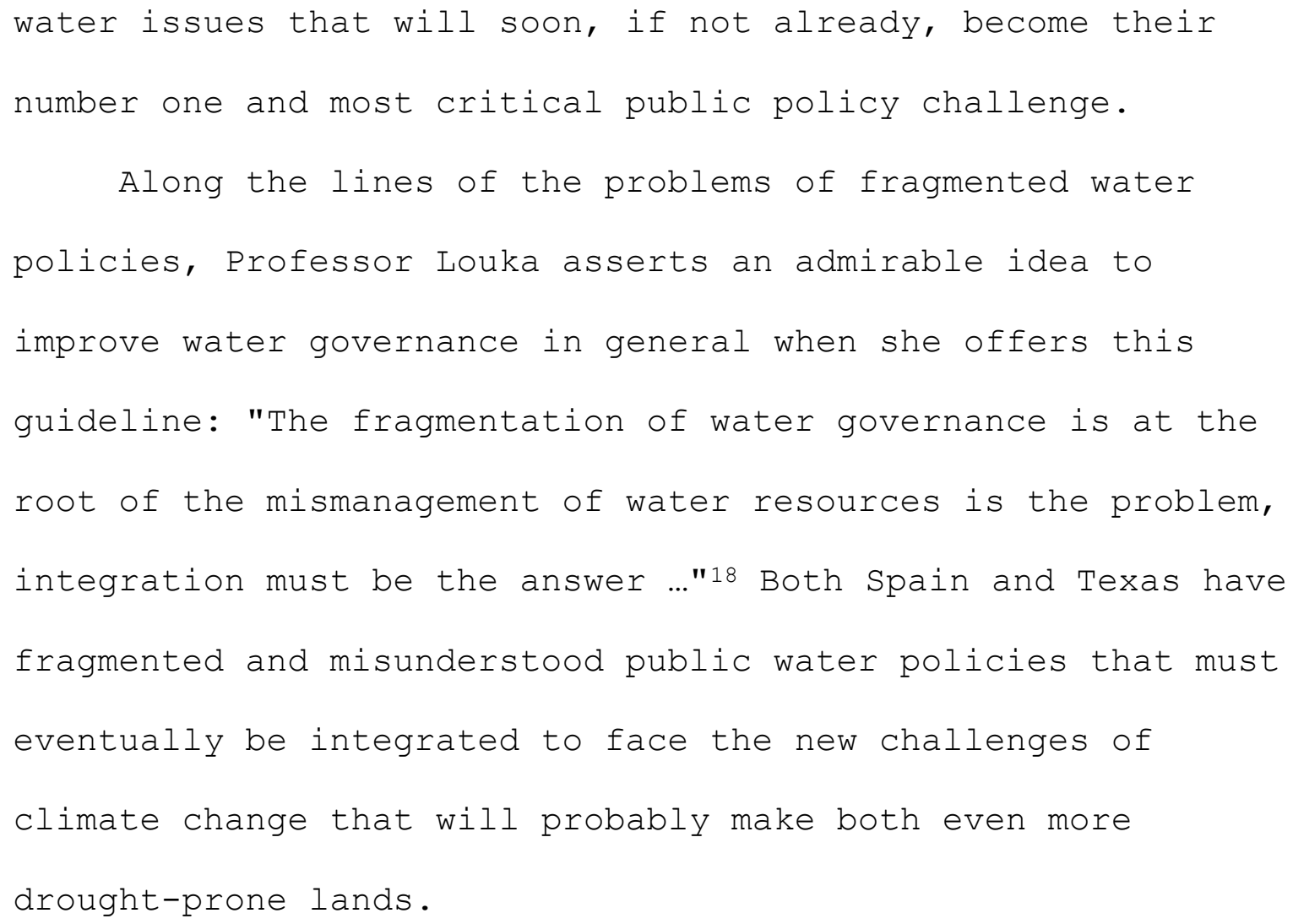

\section{Current Water Policies in Spain}

Spain's leaders in the past decades have struggled to establish a variety of approaches to reform public water policy even to point of the radical decision to take groundwater ownership out of private landowner's hands and place it in the public domain. ${ }^{19}$ The result of such a historically diametric revision ${ }^{20}$ has been received by the

\footnotetext{
${ }^{18}$ Louka. 1.

${ }^{19}$ Juan Maria Fornés, África de la Hera, Ramón Llinas, Pedro Martínez-Santos. "Legal Aspects of Groundwater Ownership In Spain.” Water International. Vol. 32, No. 4, December 2007: 676.

${ }^{20}$ Groundwater was owned by the surface landowner in Spain for centuries. See Charles Porter. Sharing the Common Pool: Water Rights in the Everyday Lives of Texans. College Station: Texas A \& M University Press, 2014. 135. See also Michael C. Meyer. Water in the Hispanic Southwest, 178, 179. Refer to Siete Partidas (Seven-Part Code) Partida 3, Titulo 28, Ley 1 (part 3, title 28, law 1).
} 
Spanish citizenry in what could best be described as general

"civil disobedience."21 According to Spanish water rights

experts Fornés, de la Hera, Llinas, and Martinez-Santos

(hereinafter referred to simply as Fornés):

The 1985 reforms of Spain's Water Law put groundwater under public ownership. While this posed an evident change in groundwater rights, the practical implications of the law have not been so significant. The 1985 Water Law did introduce significant changes for those wells drilled from 1986 onwards. However, these were only a very small share of the total. Therefore, the 1985 Water Law left things more or less as they were with regard to pre-existing wells, which are still the overwhelming majority. This non-committed approach on the part of the legislator is sometimes interpreted as a way of escaping potential social and political unrest. ${ }^{22}$

In response to its citizens concerns, the Spanish government appeared to me to enter into a bidding war against itself for several years.23 After 1985, each new proposal relating to groundwater ownership resulted in a general failure of public acceptance. ${ }^{24}$ Since the people of Spain seem to be generally ignoring the proposed reforms in groundwater ownership, it appears to me that spain's groundwater policy is fragmented and inconsistent. Some Spanish legal experts recently

\footnotetext{
${ }^{21}$ Fornés et al. 682.

${ }^{22}$ Ibid. 677.

${ }^{23}$ Ibid. 676-684. The authors discuss the diligent efforts of legislators to respond to the disobedience with yet another offer of management ideas each rejected and virtually ignored rarely enforced due to lack of funding. The authors declare the situation as "very discouraging" and deem "hydrological insubordination" as the Spanish citizenry's continued response to groundwater management and ownership reforms.

${ }^{24}$ Ibid.
} 
escalated the debate by making constitutional arguments against the water law "reforms."25 In Texas, the water policy is similarly fragmented.

\section{Current Water Policies in Texas}

All surface water is owned by the state of Texas and is managed and regulated by one agency, the Texas Commission on Environmental Quality (TCEQ). ${ }^{26}$ Groundwater on the other hand, is owned by the private surface landowner above it and is partially regulated by 100 locally organized groundwater conservation districts (GCDs), each having its own set of rules and regulations loosely framed by chapter 36 of the Texas Water Code. ${ }^{27}$ There is not any true regulatory relationship or checks and balances between surface and groundwater regulatory agencies in Texas which means Texas water policy is all but fatally fragmented. The current water law in Texas makes the integration of understandable, acceptable, and workable overall water policy all but impossible, even if any citizen-based political will existed (it does not) to develop an integrated water policy. ${ }^{28}$

\footnotetext{
${ }^{25}$ Fornés et al. 680.

${ }^{26}$ Charles Porter. Sharing the Common Pool: Water Rights in the Everyday Lives of Texans. College Station, Texas A \& M University Press, 2014. 24.

${ }^{27}$ Ibid. 40.

${ }^{28}$ Throughout my personal interviews with citizens, stakeholders, and water regulators across the entire state of Texas over the past 16 years, there is one common theme I hear consistently without reservation - the people say "Keep the state out of my/our business."
} 
Looking at social control using public water policies through the lens of current and past experience in Texas and Spain informs this study and is applicable around the globe.

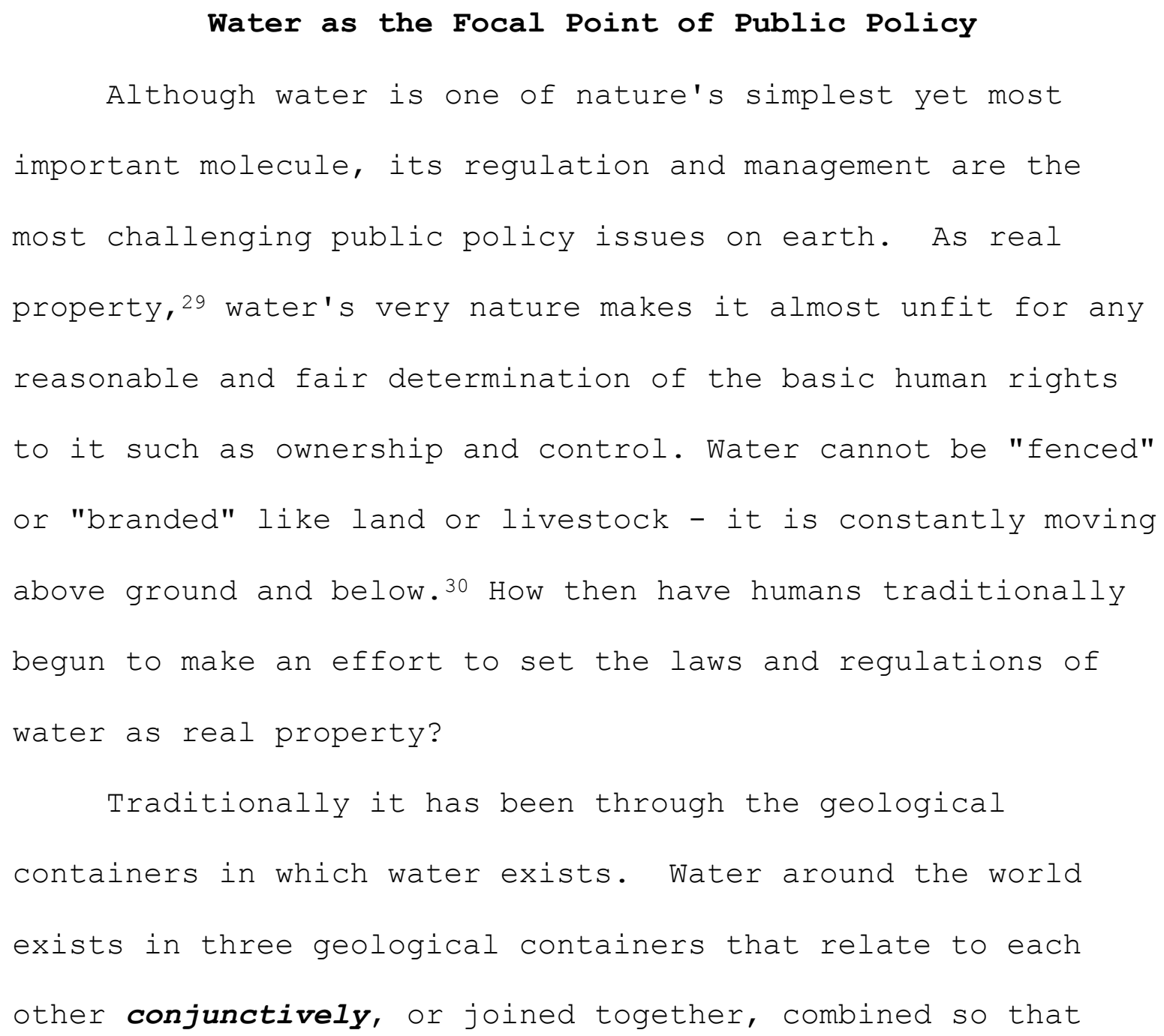

\footnotetext{
29 "Real property" is property consisting of land, buildings, crops, or other resources attached to or within the land including any improvements or fixtures permanently attached to the land or a structure on it. In Texas, water is considered a "real property" that in the case of groundwater which is owned by the surface land owner. The surface landowner's groundwater ownership interest is considered to be "vested" that requires the government to protect the private ownership against challenges.

${ }^{30}$ Charles Porter. Unintended Consequences: The History of Groundwater Regulation in Texas. Presentation to the Texas Alliance of Groundwater Districts Quarterly Meeting, Austin, Texas, February, 2007.
} 
changes in one directly results in changes to the other. 31

The conjunctive relationship of the geological containers of water is a consideration that must not be overlooked in making workable public water policies. An example of the conjunctive relationship of the geological containers most have experienced at one time or another is when we have waded in a creek and felt cooler water bubbling up around our feet; a source of groundwater is feeding the creek in which we stand. Further down the creek, we may have seen a small whirlpool. This whirlpool or drain feeds the groundwater or as is the case in many places in Texas, the entire creek or even river disappears underground only to reappear in a spring downstream somewhere. Attempting to manage water without cognizance of the conjunctive relationship between surface water and groundwater is pure folly, yet in official legal Texas water policy today, the conjunctive relationship of the containers of water is ignored.

The first and most obvious geological container is surface water or water that flows on the surface of the land in a watercourse 32 such as a stream or river. Groundwater

\footnotetext{
${ }^{31}$ Porter. Sharing. 8.

32 "Watercourse" in Texas law is not found in the statutes but in the 1925 case Heofs v. Short, 273 S.W. 785 (Tex. 1925). "When it is said that a stream in order to be a natural water course to which water rights attach must have bed, banks, a current of water, and a permanent source of water supply, we have only described in detail such physiographic and meteorological characteristics as make the use of the stream for irrigation practicable. When it is once shown that the waters of a stream are so confined and persistent in their course,
} 


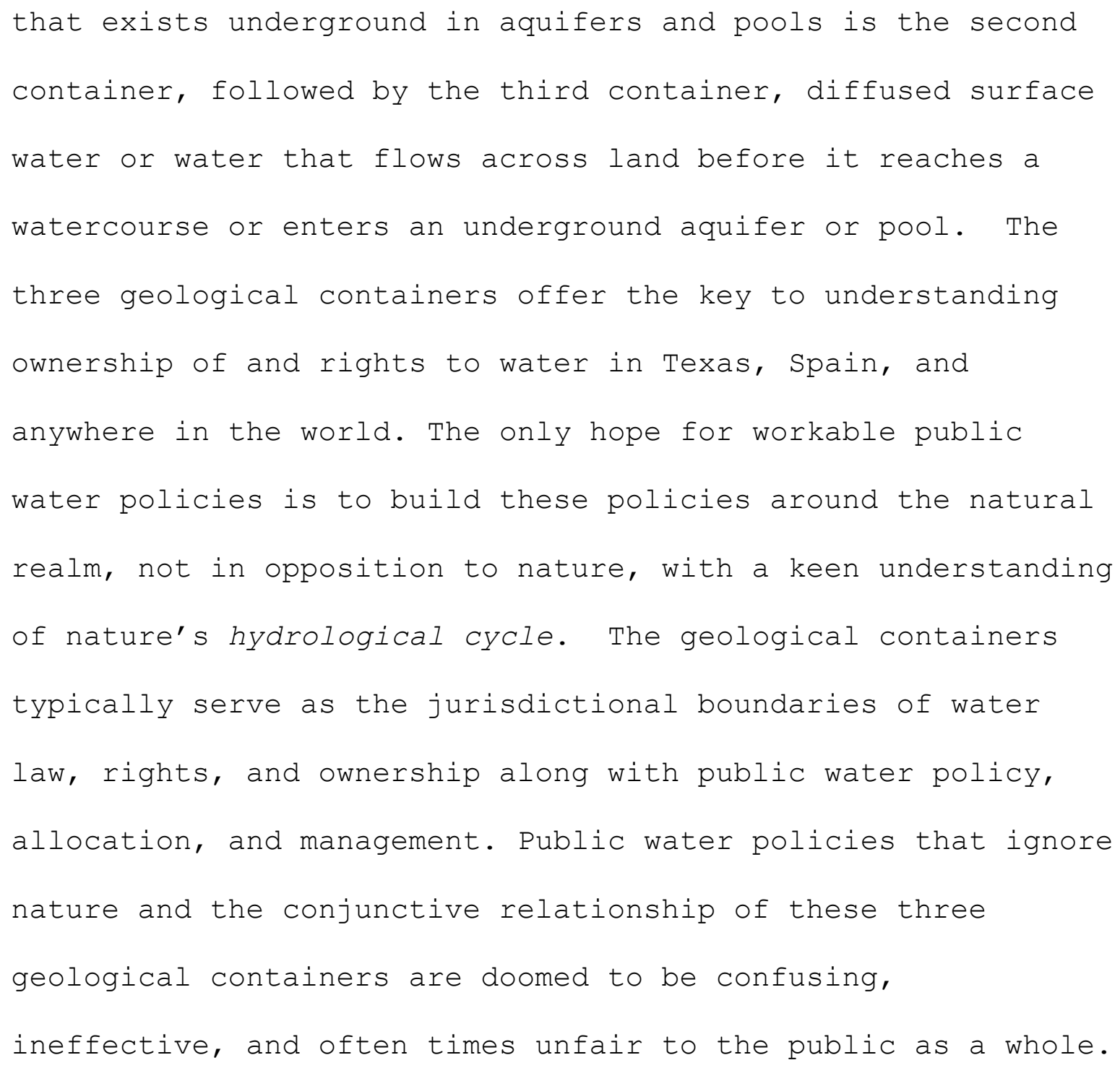

and flow with such frequency and volume that it is both practicable and valuable to irrigate therefrom, it is a stream to which such water rights attach."

With reference to the phrase 'definite and permanent source of supply of water", frequently used by the courts as describing a necessary requisite of an irrigable stream, all that is meant is that there must be sufficient water carried by the stream at such intervals as may make it practicable to irrigate from or use the stream. ... The authorities frequently say that a natural watercourse must have a permanent source of water supply. This however merely means that the stream must be such that similar conditions will produce a flow of water, and that these conditions recur with some degree of regularity, so that they establish and maintain a running stream for considerable periods of time. Farnham on Waters, Vol. 2, § 457; Ruling Case Law, Vol. 27, pp. 1065, 1066; Kinney on Irrigation, Vol. 1, § 306.” 
Since water is the common denominator of all life on earth no matter the culture, legal system, or location, public water policies are the fundamental foundation or cornerstone of community formation. Public water policy formation is the "prelude to community formation" anywhere. Without fair, workable, and transparent public water policy any society is threatened with tyranny and economic destruction, especially in the arid areas now living under severe drought and the continuing threat of long term warming trends worldwide.

Some nations, their states, or other political subdivisions often use public water policy as a weapon of social control. For example, anti-growth advocates in the western United States subtly lobby against development of new water infrastructure which includes not only fresh water supplies but also sanitary sewage water 33 in order to limit population growth. Some city governments regulate growth through their planning and zoning departments by using water infrastructure planning as their most powerful tool of social control. National governments that want to control dissident behavior or force unwanted population away from any given

\footnotetext{
${ }^{33}$ Sanitary sewage is wastewater of all types that has been used by human beings.
} 
geographical area use the periodic denial of water as the ultimate weapon of social control.

\section{Three Hypotheses To Be Explored in This Study}

The idea of public water policies being used as the ultimate weapons of social control is explored in this study's three hypotheses. The hypotheses are:

1. The three pillars of society can be controlled by the supra-legal authority of central governments over member sovereign states' public water policies;

2. The three pillars of society can be controlled by the length of time it takes courts to resolve conflicts in public water policy; and,

3. The three pillars of society can be controlled by promulgating formal and informal water policies as weapons to control dissident behavior or to protest other government policies.

This study concerns the use of water policy as a means of social control by examining in chapter 4 the conflict between central governments and its member states using 


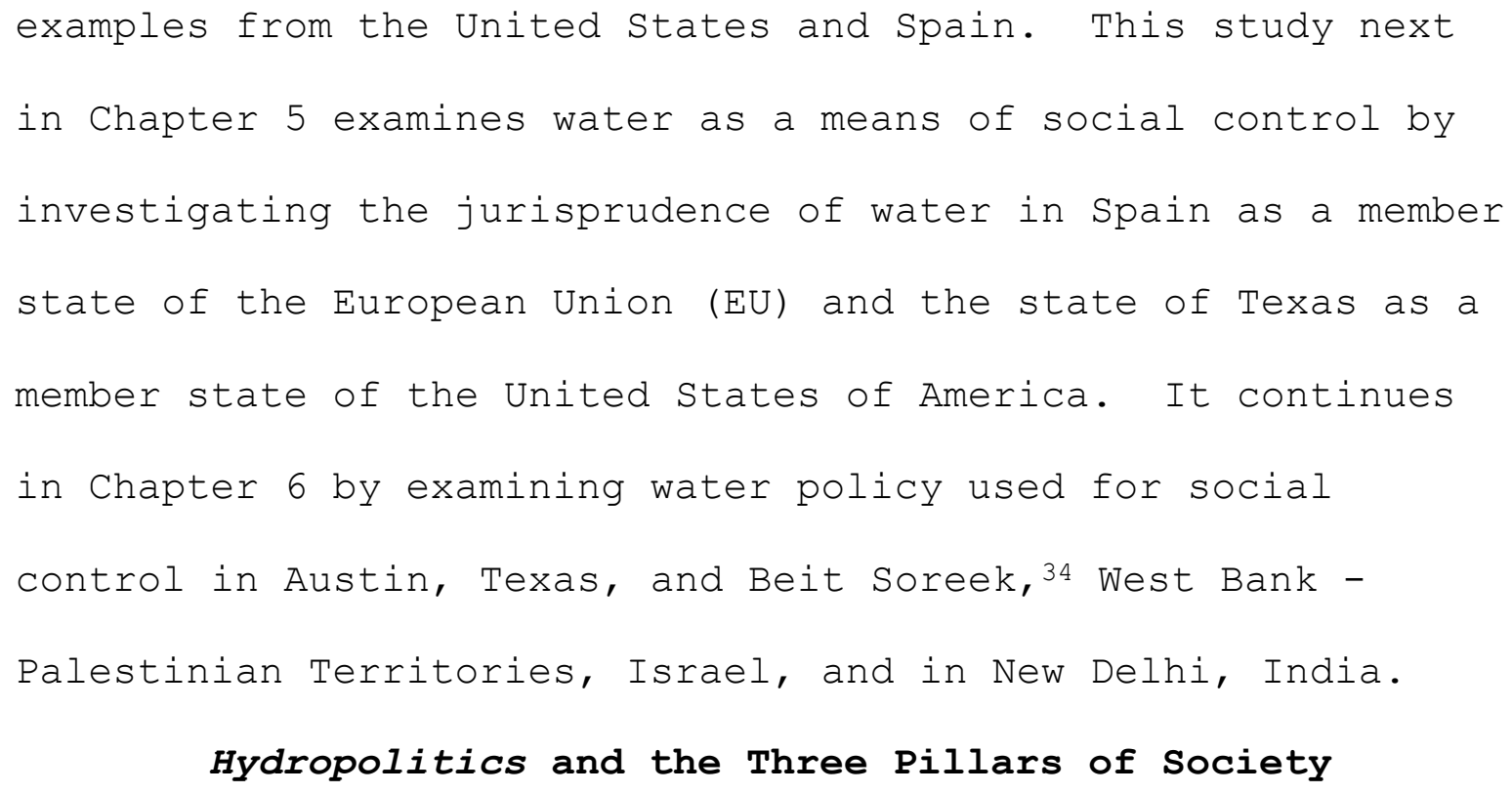

\footnotetext{
${ }^{34}$ Beit Soreek is a village in between Jerusalem and Ramallah in the occupied West Bank territory of Israel.

35 Anthony Turton and Roland Henwood (editors). Hydropolitics in the Development World: A South African Perspective. Pretoria: University of Pretoria, 2002. 16. The authors support the use of Dr. David Easton's 1965 definition of politics which is "the authoritative allocation of values in society" but with a modification by adding water to arrive at their clear and concise definition "the authoritative allocation of values in society with respect to water" which I embrace. Further fundamental considerations are applicable in the process of political analysis, according to Turton and Henwood, "In scrutinizing [sic] his [Easton's] definition, the following becomes apparent:

- Politics is a dynamic and ongoing process.

- Central to this process is the allocation of values via laws and policies.

- This implies decision-making of some kind.

- Decision-making favours [sic] some over others.

- This implies an element of contestation as no universal set of values exists.

- These values are being applied in an authoritative manner.

- This implies contestation over the legitimacy of the authority concerned.

- This also means that some are favoured whereas others are not, so who gets what, when, where and how becomes relevant."
} 
say all three pillars of society are grounded in the "liquid foundation" of water policy. The significance of water policy in the strength and reliability of the three pillars in spain for example are indicated in this astute comment made by Fornés,

While it is true that the role of groundwater in Spain's water policy is better understood today than it was before, improvements take place very slowly, causing significant damage to spain's economy and environment... In turn, these authorities [basin authorities who are ostensibly responsible for groundwater policy management] are unable to manage groundwater resources, often due to the lack of an appropriate mindset or the necessary means and support... Political willingness is essential to success. ${ }^{36}$

Fornés alludes to all three pillars, the economy, the environment, and human relationships, in this case, the human relationship with the government in the very appropriate reference to the "political willingness" of the people.

The answer to the central research question in this study involves an assessment and analysis of public water policies as weapons of social control, therefore the term social control first must be defined and understood.

\section{What is Social Control?}

What is meant in this study by the term social control? According to the Oxford Bibliographies, that it seems to me

\footnotetext{
${ }^{36}$ Fornés et al. 682.
} 
must be amended with the addition of the phrase attempts to

maintain, social control is:

...the study of the mechanisms, in the form of patterns of pressure, through which society [attempts to maintain] maintains social order and cohesion. These mechanisms establish and enforce a standard of behavior for members of a society and include a variety of components, such as shame, coercion, force, restraint, and persuasion. 37

In order to thoroughly analyze the central research question of this study, I propose four new terms to fully describe types of social control that specifically relate to water policy. The first type of social control proposed here is "due process" social control. "Due process" social control is defined as the normal governmental processes which include rules and standards of behavior that originate in constitutions, originate in legislatures or parliaments via the normal law making process, originate in the regulatory agencies appointed by the legislative branches to make rules and enforce implementation of a new law, and originate in court rulings that modify the impact of new rules and standards of behavior. Constitutions set out the due process of government that allows ostensibly for the will of the people to determine rules and standards of behavior.

\footnotetext{
37 Jason Carmichael, McGill University provided this definition to the Oxford Bibliographies found at http://www.oxfordbibliographies.com/view/document/obo-9780199756384/obo-9780199756384-0048.xml .
} 
The second type of social control proposed here is "diplomatic" social control. This type of social control is defined as originating between sovereign nations or states via diplomacy in treaty negotiations. A good example of "diplomatic" social control is in the EU treaties establishing the Court of Justice, other agreed upon EU laws such as environmental laws, or older and less complicated examples in North America such as the 1944 International Treaty between the United States and Mexico and the establishment and joint operation of the International Boundary Commission, the manager of the shared waters of the Rio Grande, the Colorado River, and others.

The third type of social control proposed in this study is "deceptive" social control. This type of social control is defined as originating in government corruption, misrepresentations, coercion, restraint, misdirection, shame, and emotions. Many political groups use water as an emotional issue to meet other social or political agendas, such as limiting growth in a community, that oftentimes veil or hide the real agenda, hence their public positions are "deceptive:" verging on misrepresentations or even fraud. The study includes several examples of deceptive social control and the financial and value consequences that result from this deception. The study discusses in great detail the 
financial and social consequences, both intended and unintended, of deceptive social control.

The fourth type of social control proposed by this study is "destructive" social control. The relationship between Israel and the occupied Palestinian territories and vice versa ${ }^{38}$ are examples of destructive social control. Most recently, an even more blatant and sad example is found in the Jats of India and their decision to block and destroy part of the surface water canal that provides $60 \%$ of the water used by the city of New Delhi, one of the world's most populous cities. ${ }^{39}$ The unintended consequence of the Jats' "destructive" action of social control was an immediate shortage of water for over ten million New Delhi residents. The destructive action by the Jats resulted in rioting and even several deaths. As the results of this study's research are revealed, it demonstrates the use of the proposed types of social control to help the reader better understand how public water policies are used as the ultimate weapons of social control.

\footnotetext{
${ }^{38}$ From my personal interviews and research, both of the extreme positions taken by some Israelis and some Palestinians exhibit "destructive" social control. This discussion is expanded in Chapter 6 of this study.

${ }^{39}$ Different sources attribute New Delhi as being the fifth largest city in the world.
} 


\section{What is a Society?}

Drilling deeper into the definition of social control, another even more basic question arises. What is a society? Traditionally, sociologists define society from the three theoretical perspectives: functionalism, conflict, and symbolic interaction. Functionalists consider society as a machine made of many parts each of which has a function. A functionalist considers society to be "a social system composed of parts that work together to benefit the whole." From a functionalist point of view society functions when all the parts work properly as planned. When a part or parts fail to function, these failures are considered dysfunctions. Functionalists believe that a dysfunction becomes a social problem when some part of the system fails. Sociologist James M. Henslin opines that functionalists generally blame the failure on "rapid social change." Social controls are put in place to ensure society as a whole functions properly. Water policies that are dysfunctional for society can wreak havoc throughout any society by weakening the three pillars, the environment, the economy, and human relationships. Dysfunctional water policies can cause long term damage to the environment, can cause economic breakdowns, and can cause 
human relationships to enter into brutal and violent conflict. ${ }^{40}$

Conflict theorists define society as "groups competing with one another within the same social system." Around the world during drought conditions competition for water is fierce and likely an omnipresent worry just under the cognizant surface of daily life even in wet years because water availability has such profound control of everyone's lives. Conflict theorists, according to Henslin, consider something a social problem when "authority and power are used by the powerful to exploit weaker groups." The most obvious conflict occurring over water occurs in Israel in their relationships to the Palestinians living in the West Bank and the Gaza Strip. Israel has virtually omnipotent power in water issues in their region and use that power to directly control Palestinians' daily lives as you will read later in this study. Conflict theorists feel that social problems are the inevitable outcome of interest groups competing for limited resources. ${ }^{41}$

Sociologists that follow the theory of symbolic interactionism focus on how people in a given society make

\footnotetext{
${ }^{40}$ James M. Henslin. Social Problems: A Down-To-Earth Approach. (Boston: Pearson, 2011) 28-44.

${ }^{41}$ Ibid.
} 
sense out of life by seeing the world through symbols. These theorists feel peoples' patterns of behavior are always changing and when something becomes a social problem it is because one set of definitions are accepted by some and those with competing views are rejected. For example, in Texas, based on ancient Spanish legal concepts and practices, a person's right to surface water is based on an appropriative grant $^{42}$ from the crown or government. For over 300 years in Texas, water rights have followed the spanish example by being prioritized by "first in time, first in right" which allocates water in times of drought or water shortages by giving priority use of the water to senior rights holders to the detriment of junior rights holders. Over the years these definitions have been accepted for the most part in surface water policy. In Texas though symbolism and generally accepted ideas of what is normative, use of groundwater does not include actual transfer of groundwater via private providers from one region to another. Regardless that the water laws of Texas do not allow discrimination against transfers of privately owned groundwater from region to region, the people in the source region simply do not accept the law and completely reject all competing viewpoints.

\footnotetext{
${ }^{42}$ Porter. Sharing. 27.
} 
Symbolic interactionists consider a social problem to exist whenever any group feels a situation is a social problem in their sole discretion. What they determine to be a social problem becomes a social problem for that group without any consideration of other definitions regardless what the law of the land may be. Later in this study this phenomena is explored in detail. ${ }^{43}$

Public water policies are the ideal example of a core social problem under each sociological theory. Hence, public water policies can be used as the ultimate weapons of social control as this study will demonstrate.

Every reasonably thinking human being wants and needs water to be pure, available, accessible, and affordable. ${ }^{44}$ Every reasonably thinking human being supports fair and reasonable regulations to protect water quality and the hydrological environment. However, using peoples' trepidations, fears, and lack of knowledge of public water policies and laws to promote other agendas without considering the entire spectrum of consequences of these policies is unfair and at times, highly deceptive. The

\footnotetext{
${ }^{43}$ Ibid.

${ }^{44}$ The World Health Organization defines a human right to water to include four characteristics; the water must be affordable, acceptable, accessible, and safe. Please see, http://www.who.int/water_sanitation_health/en/righttowater.pdf and for further study, see http://www.who.int/water_sanitation_health/humanrights/en/index2.html .
} 
development of fair and transparent water policy includes an element of base human emotion no doubt, but using the way people feel about water to promote other agendas under the guise of water protection makes poor public policy. Hence, this study also considers the unintended and unrealized consequences when people choose to use water policy to accomplish other social control agendas.

I presented this study at three academic conferences in 2016, the Academic and Business Research Institute Conference in Orlando, Florida on January 7, the World History Association Conference in Austin, Texas on March 5, and as an encore at the invitation of Dr. Russell Baker, Executive Director of the Academic and Business Research Institute Conference in San Antonio, Texas on April 1. I submitted a condensed version of this study for publication in the Academic and Business Research Institutes' Research in Business and Economics Journal and it was accepted officially after peer and editorial review on May 23 (see attached letter from Dr. Barry Thornton, Editor). It is manuscript number 162390 in the journal. One peer reviewer, Lal C. Chugh, Professor of Finance at the University of Massachusetts Boston made this comment about my article:

I liked the MS and it is worthy of publication in the Journal. I recommend it for publication. It is topic worthy of attention by the economists. 
I was especially pleased by his comment - "It is a topic worthy of attention by the economists." One of my goals in making this study is to change policymaking paradigms to include all the permutations of intended and unintended consequences of any public water policy on equally as important cherished social values of any society, both environmentally and financially. It is my sincere hope that this study will assist people in making comprehensive inquiry into how existing and new public water policies impact the three pillars of any society, the environment, the economy, and human relationships. 


\title{
Chapter Two
}

\section{Review of the Literature}

\author{
There are seminal pieces of work in the literature \\ germane to my topic three of which stand out above all the \\ rest. For a current in-depth analysis of Spain's water \\ policy issues internally and in their relationship as a \\ member state of the European Union is the work edited by \\ Lucia De Stefano and M. Ramón Llamas titled Water, \\ Agriculture and the Environment in Spain: can we square the \\ circle?. Published by Taylor \& Francis Group, London, UK in \\ 2013, the Editors gathered together articles on various \\ topics written by more than 20 water experts a group \\ consisting of academics and professionals. It is by far the \\ finest set of non-biased analytical works on the topic of \\ water management in spain. The authors first examine the \\ political framework and institutions, next discuss water uses \\ and resources in spain under the umbrella of the movement \\ towards "Integrated Water Resource Management", followed by \\ detailed critical analysis of water and the environment, \\ water management mechanisms, and rounded up with three case \\ studies. Every article is footnoted in great detail from \\ hundreds of references. If there is a current reliable
}


encyclopedia on water law and policy in spain this seminal work edited by De Stefano and Llamas is it.

Another seminal book directly germane to this study is Professor Elli Louka's Water Law and Policy published by Oxford University Press of New York in 2008. Even though the book was published some 8 years ago it remains a timely, accurate, and reliable resource to understand European water law and policies.

For water policy in Texas, the books I authored, Spanish Water/Anglo Water and Sharing the Common Pool: Water Rights in the Everyday Lives of Texans both published by Texas A \& M University Press in 2009 and 2014 respectively, offer the public the only books written ever whose subject is only Texas water policy from the broad perspective that includes the historical roots of Texas water law from their inception of Spanish Colonial times to today's current water policies and problems.

The work by authors on the water relationships between Israelis and Palestinians are many in both books and journal articles. I find all the work to be highly polarized to the point of almost ineffectiveness. The bulk of the work published in books comes from Israeli or Jewish authors and from the Israeli viewpoint; most are highly biased and prejudicial with subjective opinions that do not necessarily 
reflect the facts. Palestinian authors have published in magazines and online blogs and journals; their viewpoints are skewed in exactly the opposite direction from the Israelis. It is simple to see the difference in views and easy to report. The Israelis authors tout Israel's fairness to and financial support of water projects and availability for the unappreciative Palestinians. The Palestinian authors claim Israel has deliberately and maliciously at times restricted water to the territories and the Palestinian people have been and are continuing to be subjected to serious daily hardships over water. This study comments on and analyzes the works of all the authors and supplements the published works with personal interviews of people "on the ground" in the territories and in Israel so the reader form their own conclusion on whether or not Israel uses water policy as an ultimate weapon of social control over the Palestinians. After my review I feel Israel absolutely does use water for social control of the Palestinians to the point of long-term pressure at such a level as to eventually make life so miserable at the base core, water availability, that the Palestinians will simply leave the territories.

A key work on the Israeli view is written by seth M. Siegel in Israel's Solution for a Water-starved World: Let There Be Water published by St. Marten's Press of New York in 
2015. A key work on the Palestinian point of view is by Elisabeth Koek in "Water for One People Only: Discriminatory Access and 'Water Apartheid' in the OPT' published in Ramallah - West Bank - Palestine: Al-Haq in 2013. Siegel's work has wonderful detail on water projects and the successful development of and enhancement of the limited natural water sources in Israel, but at all times in all sections he praises Israel almost to the level of a heroic tale. The limited space he gives to the Palestinian water situation is simply to share his opinion that the Israeli government has gone far and beyond the norm in providing water for the unappreciative Palestinians. Elizabeth Koek's views seem to me to be more neutral and non-biased; her basic opinion matches the results of my personal interviews with Palestinians.

Mark Zeitoun's Power and Water in the Middle East: The Hidden Politics of the Palestinian-Israel Water Conflict published in London by I.B. Tauris \& Co Ltd. in 2012 has been heavily criticized by Israeli experts. However, I find his work intriguing and his conclusions coincide with my personal interviews of eyewitnesses.

Not surprisingly, the Palestine Liberation Organization Negotiations Affairs Department's publications accuse Israel of violations of international law, of coercion to force 
Palestinian communities to pay exorbitantly high prices for water from the Israeli national water company, and to divert what water there is to "illegal" Israeli settlements. Their publications offer the diametrically opposite view of the water argument in Israel and the Palestinian territories. It is obvious that Israel has all the power over Palestinian water resources in general and that this power is used in a manner in which Israel exerts social control over the daily lives of the Palestinians. Whether or not Israel deserves to hold that power or responsibly and fairly projects that power is a topic for another study.

Overall, the literature today does not directly address my subject of water as the ultimate weapon of social control, but does inform my research. It appears my work will be unique in the overall body of water policy research up to this time. 


\title{
Chapter Three
}

\section{The Study's Methodology}

\author{
In summary, qualitative and quantitative approaches to \\ research allow a different perspective of situations or \\ phenomena. These two main approaches to research are highly \\ informative especially if used in combination. \\ Adar Ben-Eliyahu, Ph.D. ${ }^{45}$
}

This study follows the qualitative method of research. In doing so, one of its more practical uses in Texas will be to inform the Texas Legislature of the need for judicial reform to allow more timely court rulings in water disputes and to offer a fair market valuation for water. Why choose a qualitative study in part based on the author's actual participation as a member of the key stakeholder associations in Texas water policy? Professor Louka offers support to the

\footnotetext{
${ }^{45}$ Dr. Adar Ben-Eliyahu is a MacArthur Foundation Postdoctoral Fellow at the Center for Evidence-Based Monitoring at the University of Massachusetts in Boston. According to Dr. Ben-Eliyahu, "In summary, qualitative and quantitative approaches to research allow a different perspective of situations or phenomena. These two main approaches to research are highly informative especially if used in combination. Each approach has its benefits and detriments, and being aware of the methods used to gather information can help practitioners and policy-makers understand the extent to which research findings can be applied."
} 
decision. Put simply, Louka opines, "A key to effective water governance is the provision of information, consultation with, and participation of stakeholders and the public in water management."46 This study, if it is to be an effective tool of change in water policy in Texas, must include firsthand information from, consultation with, and participation of stakeholders and the public. It does.

The central hypothesis of this study is that public water policies are the ultimate weapons of social control. The central research question is: How are public water policies used as the ultimate weapons of social control in today's societies?

In order to discover, explore, and seek an understanding of how water policies are used as public policy weapons for social control of the three pillars of society - the environment, the economy, and human relationships - the following three hypotheses and research questions are researched and answered:

- Hypothesis Number One - The three pillars of society can be controlled by the supra-legal authority of central governments over sovereign member states' public water policies. The research question for this hypothesis is:

${ }^{46}$ Louka. 3. 
How does the supra-legal authority of central

governments over sovereign member states' public water policies control the three pillars of society?

- Hypothesis Number Two - The three pillars of society can be controlled by the length of time it takes courts to resolve conflicts in public water policies. The research question for this hypothesis is: How does the lack of timely court rulings on public water policy conflicts change and control the three pillars of society?

- Hypothesis Number Three: The three pillars of society can be controlled by promulgating formal and informal water policies as weapons to control dissident behavior or to protest other government policies. Israel's water policies towards the Palestinians in the West Bank village of Beit Soreek, the Jats in India towards the citizens of New Delhi, and the City of Austin, Texas' water policies and actions exert social control over the three pillars of society. The research question for this hypothesis is: How do these governments and people exert social control over the three pillars of society? 


\section{Detail of the Study's Methodology}

This study uses the qualitative research methodology.

According to John W. Cresswell:

Qualitative research is an approach for exploring and understanding the meaning individuals or groups ascribe to a social or human problem. The process of research involves emerging questions and procedures, data typically collected in the participant's setting, data analysis inductively building from particulars to general themes, and the researcher making interpretations of the meaning of the data. ${ }^{47}$

There are five types of data collection in this study:

- In-depth, open-ended interviews;

- Direct observation;

- Written documents; and,

- Focus groups.

Another leading scholar, Adar Ben-Eliyahu, Ph.D., a MacArthur Foundation Postdoctoral Fellow at the Center for Evidence-Based Monitoring at the University of Massachusetts in Boston, offers her opinion of the benefits of the qualitative approach to research, which swayed my choice of research methodologies:

- Identification of new and untouched phenomena;

- A potential to discover a better understanding of mechanisms;

\footnotetext{
${ }^{47}$ John W. Cresswell. Research Design: Qualitative, Quantitative, and Mixed Methods Approaches. (Los Angeles: Sage Publications, 2014) 4.
} 
- One-on-one and anecdotal information;

- Verbal information that may sometimes be converted to numerical form; and,

- Revelation of information that would not be identified through pre-determined survey questions. ${ }^{48}$

Leading research methodology scholar Michael Quinn Patton provides an assessment of the qualitative researcher, "The validity and reliability of qualitative data depend to a great extent on the methodological skill, sensitivity, and integrity of the researcher."49 In response to Patton's assessment, and another reason I chose the qualitative methodology is found in a brief look at my past academic interest in water policies.

I dedicated the past 16 years of my life to educate the public in water rights and how water rights affect their everyday lives, to put water law, rights, and public policies into the overall context of their duties and responsibilities as professionals, citizens, and participants in society as a whole. I began my long term research at the chronological beginning of the Spanish roots in Texas water law. I explored

\footnotetext{
${ }^{48} \mathrm{http}$ ://chronicle.umbmentoring.org/on-methods-whats-the-difference-between-qualitative-and-quantitativeapproaches Accessed many times but specifically last on May 1, 2016.

${ }^{49}$ Patton, 11.
} 
and shared my understanding of the historical and current relationship of the water laws of Texas and Spain in my public and academic books and articles and in my continuing education for professional credit in both the legal profession and real estate brokerage. For a decade I have taught water history and rights at the college level at st. Edward's University. As of May 4, 2016, I completed my 218th water law/water rights speech somewhere in the United States, this list dates only from July 2012, and does not include the hundreds of speeches, lectures, and classes prior to that date. All of these speeches were at the invitation of some group of educators, some group of stakeholders, a committee of the Texas Legislature, or at the request of a member of the Texas House of Representatives.

To take my research from a purely academic approach to cause actual change public water policy, I authored and organized House Bill 1221 in the 84th session of the Texas Legislature, a bill that became law in Texas on June 16, 2015.50 A two year process, I organized ad hoc committees of attorneys and stakeholders, at my sole unreimbursed expense,

\footnotetext{
${ }^{50}$ http://www.capitol.state.tx.us/BillLookup/History.aspx?LegSess=84R\&Bill=HB1221. See also at the same site mention of my sworn testimony at the House Natural Resources Committee hearings and the Senate Business and Commerce Committee hearings http://www.capitol.state.tx.us/tlodocs/84R/witlistbill/pdf/HB01221H.pdf\#navpanes $=0$ and http://www.capitol.state.tx.us/tlodocs/84R/witlistbill/pdf/HB01221S.pdf\#navpanes=0.
} 
to draft the bill, find sponsors in the Texas House and Senate, present and gain the unanimous approval of the Texas Alliance of Groundwater Districts, the Texas Association of Realtors, and the Texas Water Conservation Association among others. I testified under oath at the hearings considering the bill held by the House Natural Resources Committee and the Senate Business and Commerce Committee in support of the bill. The total population of the trade associations and political groups I gained support from for the new bill exceeded 200,000 people.

The bill amended the Texas Property code to include a legally required question asking each seller of any single family home in Texas if the property for sale was in the jurisdiction of a groundwater conservation district, the preferred method of groundwater management and regulation in Texas. The answer to the question became a part of the mandatorily required Sellers Disclosure Notice in Texas, a notice that must be provided to a potential purchaser of any single family home while the potential purchaser is making his or her decision to commit to buy. ${ }^{51}$ It was the first time in the 66 year history of the groundwater conservation

\footnotetext{
${ }^{51}$ See Texas Property Code, 5.008.
} 


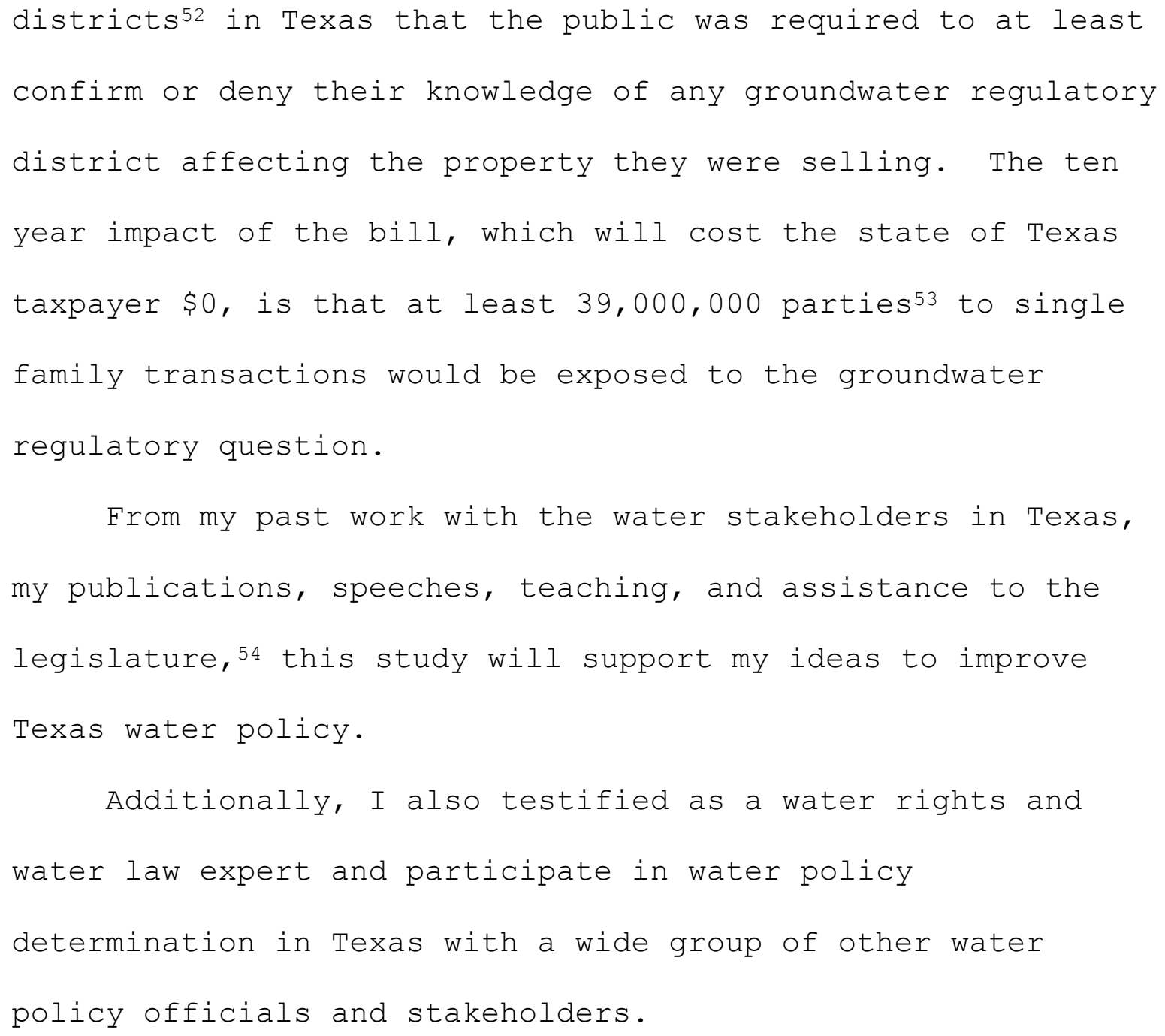

${ }^{52}$ See Charles Porter. "Of Urgent Concern: What Prompted House Bill 162, the Groundwater Conservation Act of 1949." Published in the papers of the Texas Water Law Conference, Austin, Texas 2015. I also presented the paper at the conference on October 6, 2015 as the "Featured Presentation" of the conference.

${ }^{53}$ This figure is based on only the Multiple Listing Service (MLS) single family homes listed in the MLS systems in Texas, not any other potential sale by owner or a listing for sale not placed in the MLS system. MLS listings alone have averaged 1,300,000 per year in Texas. The parties are the seller, the buyer, and at least the listing agent or 3 , hence $3,900,000$ parties per year for 10 years equals $39,000,000$. At least $60 \%$ of the time, there is a buyer's agent adding another $13,000,000$ parties. The law requires sellers to provide the notice regardless of listing the home with a real estate agent. At best $85 \%$ of all home sales in Texas are via MLS systems, so over 10 years, many more Texans will be exposed to the question. A more reasonable estimate would be that the impact could easily exceed 45,000,000 people during the first 10 years.

${ }^{54}$ On February 9, 2016, I testified in Burleson, Texas at the request of the Texas House Natural Resources Committee in a public hearing of the committee on the subject of private property rights and water in Texas. I was asked to discuss the impact on private property rights in water of the proposed (and stayed) Waters of the United States Environmental Protection Agency Rule and groundwater regulations in general in Texas. 
For further detail in understanding my higher education teaching, I developed, authored, and have taught global water policies at St. Edward's University, a class named "Global Water Challenges" also known as CULF 3331. Along with this class, I have been the instructor and designer of three (3) Cultural Foundations (CULF 3330/3331) Water Workshops. These three (3) workshops were accomplished in the fall semester 2009, the spring semester 2011, and the spring semester 2013 . Over the three (3) workshops, 2,000 St. Edward's students studied and mediated moot global water disputes in international transboundary surface waters and international transboundary aquifers. This fall beginning in August 2016, I have designed the fourth set of water workshops. I also am the author of the only Texas Real Estate Commission (TREC) Continuing Education Course on water rights in Texas, "Water Rights for Texas Agents" TREC course \#04-00-030-6748. This course was awarded the Best Ethics Education Course in the state of Texas in 2008. I have the skill, competence, and rigor to prepare a valid and reliable study as my brief bio indicates. 55

\footnotetext{
${ }^{55}$ Charles Porter is an award winning author, speaker, testifying real estate expert, and a full time Visiting Professor in the College of Education at St. Edward's University. He also serves on the Advisory Council of the Briscoe Center for American History at the University of Texas. His newest book Sharing the Common Pool: Water Rights in the Everyday Lives of Texans (Texas A \& M Press, 2014) hit the bookstores on May 15, 2014. He is also the author of Spanish Water/Anglo Water (Texas A \& M Press, 2009) winner of the 2011 San Antonio Conservation Society Publication Award and the 2011 Texas Old Missions and Forts Restoration Association Book Award for outstanding published book contributing to a better understanding of Spanish Colonial Texas. He won The Texas Catholic Historical Society's Catholic Southwest Journal of
} 


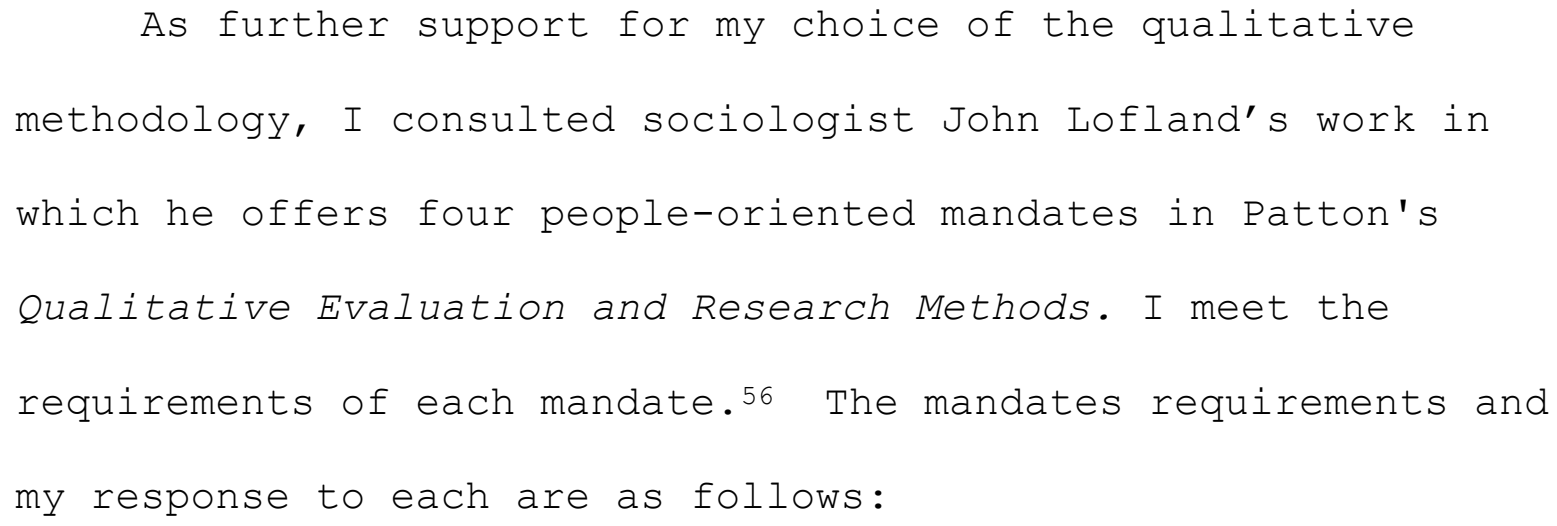

- The qualitative methodologist must get close enough to the people and situation being studied to understand in depth the details of what goes on. (I am deeply involved and have been for almost two decades in "what goes on" in water policymaking.);

- The qualitative methodologist must aim at capturing what actually takes place and what people actually say: the perceived facts. (I have testified live as an invited

History and Culture 2009 Robert S. Weddle Award for the article "Querétaro in Focus: The Franciscan Missionary Colleges and the Texas Missions." He won The East Texas Historical Association's East Texas Historical Journal's 2013 Chamberlain Award for the article "The History of W. A. East v. Houston and Texas Central Railway Company, 1904: Establishment of the Rule of Capture in Texas Water Law or 'He Who Has the Biggest Pump Gets the Water'."

His teaching awards at St. Edward's University include the 2013 Hudspeth Award for Innovative Teaching, the 2011 St. Edward's University Outstanding Adjunct Faculty Award, and the 2011 Best Adjunct Professor of the Schools of Behavioral and Social Sciences and University Programs. Additionally Porter was a 2008 Presidential Award Winner at St. Edward's. His Texas Real Estate Commission Continuing Education Course Water Rights for Texas Agents won the Best Education Course in the state of Texas in 2008; his Mediate, Arbitrate, Litigate TREC Continuing Education Course won the Best Education Course in the state in 2005. He was awarded the Peacemaker Award by the Austin Dispute Resolution Center in 2007. He was elected and served as Chairman of the Board of Directors of the Austin Board of Realtors in 2007. For further information please visit www.charlesporter.com.

${ }^{56}$ Patton. 32. 
expert on Texas water policy making and serve on a variety of committees in stakeholder groups that make water policy in Texas including the Texas Water Conservation Association Surface Water Committee and a subcommittee, the Texas Association of Realtors Public Policy Subcommittee on Utilities and Infrastructure, and in my own ad hoc committees of stakeholders in making Texas water policy.);

- The qualitative data must include a great deal of pure description of people, activities, interactions, and settings. (My data comes from in-person live observance and participation in water policy making in Texas.);

- The qualitative data must include direct quotations from people, both what they speak and what they write down. (My data includes years of my collection of direct quotations from my personal live interviews and participation in water policymaking in Texas and also includes what the people observed have written down.); and,

- Designing and conducting interviews with participants in the making and interpretation of Texas water policy in 
the courts specifically to determine the demand for a special water court in Texas. No one has every proposed a study like this one. I have gained the total support of the Texas Alliance of Groundwater Districts, the Texas Water Conservation Association, and many in the legal profession.

I have been closely committed to another of Patton's key descriptions of what a qualitative researcher strives to accomplish. According to Patton, [qualitative research is the] "study of people in situ ${ }^{57}$... Since a major part of what is happening is provided by people in their own terms, one must find out about those terms rather than impose upon them a preconceived or outsider's scheme of what they are about."58 For almost two decades I have actively participated in the subject of this study.

Patton further offers six (6) data-collection questions to guide qualitative researchers. Please find below my answers as indications of my strategies:

\footnotetext{
${ }^{57}$ Merriam Webster defines in situ as "'in the natural or original position or place."

${ }^{58}$ Patton. 32-33.
} 
1. Who is the information for and who will use the findings? All water policymakers and stakeholders in Texas, Spain, and elsewhere around the world as well, will be users of the information in this study. The information from the study is designed to assist and inform water policymakers in Europe and the United States along with informing the general public of some of the consequences water policy has on the three pillars of society.

2. What kinds of information are needed? The kinds of information needed include but are not limited to live interviews with the attorneys who are actually trying the water policy dispute lawsuits in Texas and Spain, focus group meetings to discuss problems and concerns in water policy making, information from stakeholders as to the current status of water law in the United States via Texas stakeholders and in the European Union via Spanish stakeholders. Court rulings, academic journal articles, personal interviews with everyday citizens as to the affect water policy has on their daily lives, field observations and live testimony, and books germane to the subject are examples of other information needed and considered. 
3. How is the information to be used? For what purposes is evaluation being done? The information will be used in informing the shape of future water policies in Texas, spain and elsewhere. The evaluation is being done to offer all the permutations of water policy and the consequences they could have on the three pillars of society.

4. When is the information needed? The information can be used immediately; I presented my preliminary findings at three academic conferences since January 7, 2016 to great interest. The information for use in Texas specifically is needed as soon as possible and certainly before the 85 th session of the Texas Legislature in January, 2017.

5. What resources are available to conduct the evaluation? The resources available include the leading attorneys and experts in water policy in Texas and Spain, academic and law journal articles, and libraries especially the University of Texas School of Law's Tarleton Law Library.

6. Given the answers to the preceding questions, what methods are appropriate? The methods appropriate are qualitative research methods enhanced by a quantitative study of stakeholders in Texas and in Spain. 
In summary, this study seeks to improve the rationality and justice in recent and historical practices of setting water policy via the civil and administrative law systems in Texas and Spain coupled with the laws, rules, and regulations of the United States and European Union central governments. My methodology additionally uses an interdisciplinary approach that includes gathering qualitative data in order to provide a comprehensive analysis of the research problems. Specifically the working plan included but was not limited to:

- Conducting personal interviews with the disputants in civil and administrative lawsuits in which water is the subject of the dispute, the judges of the various courts in which the trials or hearings to litigate the disputes were held, past and present elected and appointed state officials, and the attorneys representing plaintiffs and defendants in past and current litigation over water issues in Texas;

- Conducting historical document reviews by reviewing the archival court documents beginning with the Bexar Archives in the 18th century through the court 
documents in modern court cases in Texas and as much as is reasonable in spain (the Tribunal keeps no written documentation of the disputant's testimony) - those decided and settled, those pending, and those under appeal;

- Designing and conducting interviews and focus groups of participants in the making and interpretation of Texas water policy in the courts specifically to determine the demand for a special water court in Texas. No one has ever proposed a study like this one. I will have the total support of the State Bar of Texas, the Texas Alliance of Groundwater Districts, the Texas Water Conservation Association, and many judges and attorneys.

- Gathering statistics about civil and administrative water litigation in the United States, Texas, the European Union, and Spain; and,

- Interviews with citizens from Israel, the city of Austin, San Antonio, Spain, and from the West Bank Palestinian Territories. 
Chapter Four

\title{
"Diplomatic" and "Due Process" Social Control: "Supra-Legal" Authority in Water and Iimitations on Sovereignty
}

\author{
Irrigation in the Indus River basin dates back centuries; by \\ the late 1940s the irrigation works along the river were the \\ most extensive in the world. These irrigation projects had \\ been developed over the years under one political authority \\ that of British India, and any water conflict could be \\ resolved by executive order. 59
}

Aaron Wolf and Joshua Newton 60

My first hypothesis is that the three pillars of society can be controlled by the supra-legal authority of central governments over member sovereign states' public water policies. How does the implementation of supra-legal authority by central governments over member sovereign states' public water policies control the three pillars of society in that nation?

${ }^{59}$ Aaron T. Wolf and Joshua T. Newton. Case Study of Transboundary Dispute Resolution: The Indus Water Treaty. http://www.transboundarywaters.orst.edu/research/case studies/Indus_New.htm, accessed March 3, 2016.

${ }^{60}$ Professor Aaron T. Wolf is a Professor at Oregon State University in The Program in Water Conflict Management and Transformation. He is an internationally recognized expert on water conflict resolution and was named a 2015 recipient of the Heinz Award in the category of public policy. 
The phrase supra-legal authority is a phrase I created

several years ago based on the Latin word "supra" meaning

above. ${ }^{61}$ Supra-legal authority is jurisdictional authority

that takes precedence other existing laws in a nation,

region, or state. A similar term is supranational authority

meaning above the authority of a nation. ${ }^{62}$ A continuing

debate in Spain and the United States, a debate that is in no

way unique in the world to these countries, involves the

issue of local control versus national control, or the issue

of sovereignty. The issue of the jurisdictional extent of

water law and policy between state sovereignty and central

government authority is ever present today and for centuries

in many regions of the world, especially in the United States

and more recently in spain. Determining water policy's

involvement in the sovereignty debate hangs like a "sword of

Damocles" over Great Britain today as they contemplate

leaving the EU commonly referred to as "Brexit."63 Quite

${ }^{61}$ I chose to develop the term as a part of my Global Water Challenges class at St. Edward's University in 2008. Since then I have shared the term and used it often in my 219 speeches about water in Texas. I used the term yet again recently in my testimony to the Texas House of Representatives Natural Resource Committee hearings in February, 2016. One of the subjects the committee asked me to comment upon was the U.S. E.P.A.'s proposed Waters of the United States ruling. The term is highly effective when describing the relationship between a state and a federal or central government. A similar term, supranational, is less descriptive and actually confusing when applied to national relationships with member states.

62 https://www.translegal.com/legal-english-lessons/supra-vs-infra, accessed March 3, 2016.

${ }^{63}$ The vote in Britain will be taken on June 23, 2016. Polls vary and lean towards remaining in the EU but the situation is in flux. Today, June 24, 2016, the British people elected to leave the EU 51.8\% to $48.2 \%$. 
similarly, this same issue has been battled for over 175

years between Texas and the United States. Likewise in 1948, this very debate came to life with potentially dire consequences for thousands in one of the world's "cradles of civilization", the Indus River Valley.

\section{Chaos Caused by the Loss of Supra-legal Authority in the Indus River Dispute}

Wolf and Newton's quote at the beginning of this chapter is taken from their analysis of the Indus River treaty that settled a dispute that began after India won its independence from Great Britain in 1948. Almost immediately, the independence, earned at the high cost of human lives, was followed by a partition of India into the new nations of India and Pakistan.

The Indus River travels from its headwaters in the disputed Kashmir Region of India and flows mostly through modern day Pakistan to enter the Indian Ocean. For decades before the partition of India and Pakistan, the regions of Sind and Punjab in British India argued over the common water of the Indus. The heart of the dispute was the overflow of Indus River water for irrigation purposes essential to the survival of millions of people in both provinces. While the area was under British rule, the supra-legal authority of Great Britain provided a single political authority empowered to hear and settle disputes between these regions. The 
partition created two separate nations and any and all supralegal authority ceased to exist, throwing the Indus River management into chaos. As the headwaters of the Indus River mostly are found in India, India's control of the upstream watersheds represented an ultimate weapon of social control over the very lives of tens of millions of citizens of the new nation of Pakistan.

Thanks to the ground-breaking efforts of World Bank President Eugene Black who offered the "good offices" of the World Bank as a mediating facility, a negotiated settlement was made between the two fledgling nations. The treaty negotiations were held from 1948 to 1960 and the agreements made are still in existence today though in a continuing state of revision and renegotiation. Wolf and Newtown summed up conceptual causes of the dispute succinctly, "Shifting political boundaries can turn intra-national disputes into international conflicts exacerbating tensions over existing issues."64 The World Bank was in the unique position with a talented leader as its President, Black. Both new nations were desperately seeking economic stability and without Indus River water for irrigation, literally millions of people in each new nation found their very lives at risk. Black not

\footnotetext{
${ }^{64}$ Wolf and Newton, http://www.transboundarywaters.orst.edu/research/case_studies/Indus_New.htm, accessed March 3, 2016.
} 
only offered an impartial third party's vital and continuous involvement but his institution was in the uniquely powerful position to provide financial incentives to spur a settlement to fruition.

The lessons learned from the Indus River dispute illustrate the immediate and critical consequences of the abrupt withdrawal of all central government supra-legal authority because everyone is aware that water is the common denominator of all life on earth. The relationship between the central government of the European Union and Spain and the United States and Texas fortunately have never reached and likely will not ever reach the level of danger the Indus River dispute did. The Indus River dispute did raise two centrally significant questions that do apply in Texas, Spain, and elsewhere in the United States and the European Union. These questions, really about the limits of sovereignty are:

- How much authority should the United States government have over its individual states' water policies?

- How much authority should the European Union have over Spain's water policies? 
This study does not offer answers to these questions, but uses these questions in part to guide ways in which water policy can be, is being, or is attempting to be used as a weapon of social control by a central government.

Along with jurisdictional authority comes the right and duty of enforcement of laws or regulatory agency rules that stem from that authority. This issue of sovereignty is complicated by the fact that the member state or nation voluntarily agreed to become part of its central government as Texas did in rejoining the United States in 1870 and Spain did when joining the European Union in the 1980s. In 2015, the issue of sovereignty erupted in the United States when a federal agency proposed a new rule involving water.

\section{The Supra-Legal Debate in the United States - The Proposed "Waters of the United States" Rule}

One of the best examples of an attempt by the United States to use public water policy as a weapon of social control at a national level occurred on May 27, 2015. The United States Environmental Protection Agency (EPA) Administrator, Gina McCarthy, proposed a new rule that came to be known as the "Waters of the United States" rule supposedly to "clarify" 1972's Clean Water Act. The EPA considers the proposed rule to be the result of "due process" from the edicts and rights they have in their agency mandate. 
This proposed rule is an example of "due process" social control. Even though it is controversial and has been "stayed"65 by federal courts, the EPA claims their proposed rule was generated properly within their jurisdictional mandate. The extent to which the EPA's behavior exceeded and exceeds their legislative mandate forms the heart of the debate.

The proposed rule was a controversial proposal that many members of Congress, property rights groups, and almost the entire agriculture industry claimed would put all surface and other waters under the full and total control of the federal agency. ${ }^{66}$ According to a press release offered by Philip Ellis, President of the Cattlemen's Beef Association, "Today, the Agency [EPA] finalized its 'Waters of the United States' proposed rule, which unilaterally strips private property rights and adds hundreds of thousands of stream miles and acres of land to federal jurisdiction." ${ }^{67}$ After review of the wording of the proposed rule, it appears to me the language is indeed ambiguous, vague, and confusing in a capricious

\footnotetext{
${ }^{65}$ According to the Legal Information Institute of Cornell University Law School a stay is "A ruling by a court to stop or suspend a proceeding or trial temporarily or indefinitely. A court may later lift the stay and continue the proceeding." https://www.law.cornell.edu/wex/stay_of_proceedings . Accessed May 5, 2016.

${ }^{66}$ Environmental Protection Agency press conference, Washington, D.C., May 27, 2015.

${ }^{67}$ Philip Ellis, President of the National Cattlemen's Beef Association, comments on AgWeb of the Farm Journal, May 27, 2015.
} 
effort by the agency to expand the jurisdiction of the clean Water Act to include potentially every drop of surface water in the United States. ${ }^{68}$

North Dakota Federal Judge Ralph Erickson stayed the proposed rule on August 27, 2015 but his stay was only applicable in 13 states. North Dakota Attorney General Wayne Stenehjem said of Judge Erickson's stay, "I am very pleased by today's ruling, which protects the state and its citizens from the serious harm presented by this unprecedented federal usurpation of the state's authority."69 Shortly thereafter, Judge Erickson's stay was appealed by the EPA and on October 9, 2015, in a 2-1 ruling, the Sixth Federal Court of Appeals delivered a ruling that protected and expanded Judge Erickson's stay to the entire United States. Some background about the EPA and the clean Water Act is necessary for a complete understanding of the context of this effort to use water as a weapon of social control by one of the most powerful agencies in the United States government.

The EPA was established on December 2, 1970; one of the duties of the agency was to protect "water". The Clean Water Act of 1972 was enacted as an attempt to better define the

\footnotetext{
${ }^{68}$ Exceptions in the rule include wastewater treatment ponds, some "ditches" (undefined in the rule), and gullies, rills, and non-wetland swales.

${ }^{69}$ North Dakota State Attorney General's Office News Release, August 27, 2015.
} 
precise jurisdiction over which "waters" the EPA and their colleague agency, the U.S. Army Corps of Engineers would regulate. Shortly after the Clean Water Act was passed in 1972, a variety of lawsuits resulted in several court rulings that along with the opinion of legal scholars decreed that the Clean Water Act's jurisdiction was limited to major navigable rivers only. Agricultural interests claimed then and continue to claim that the jurisdiction of the EPA under the terms of the Clean Water Act does not include tributaries of major navigable streams or creeks and smaller streams and definitely not include farmers' stock tanks or earth moving to create irrigation systems on private land. Throughout 2015, many people and stakeholder groups complained that the EPA illegally used social media to promote the proposed ruling before even offering it for debate in Congress or the public forum. Other complaints against the EPA rule alleged lack of transparency by the agency intentions in the proposed rule. The EPA Administrator was accused of refusing to answer inquiries by media, stakeholders, and even members of Congress.

In answer to formal complaints, on December 14, 2015, the General Accounting Office (GAO) of the United States officially addressed the EPA's use of social media in this matter by ruling that "... [the EPA] engaged in "covert 
propaganda" and violated federal law when it blitzed social media to urge the public to back an obama administration rule intended to better protect the nation's streams and surface water."70 The GAO ruling stirred anger and consternation inside the EPA and is currently under appeal.

While there is no doubt the EPA has some jurisdiction over navigable waters, the now GAO-declared illegal actions coupled with the stays by a federal judge supported and expanded by the Federal Sixth Court of Appeals, are national examples an attempt to use water as a weapon of social control. If the concerns of agricultural interests and the individual states are valid, the impact on individual property owners could very well be never before required stringent federal permit acquisition for the most basic activities, usurpation ${ }^{71}$ of state surface water laws and state and local regulatory agency jurisdictions, and decades of federal lawsuits over property rights. A farmer that is required to obtain a federal permit from the EPA or the US Army Corps of Engineers before moving soil to divert water into livestock ponds and irrigation ditches, would be subject

70 "EPA Broke Law With Social Media Push for Water Rule, Auditor Finds." New York Times, December 15, 2015.

71 "Usurpation" means taking someone's power or property by force. 
to a potentially punitive level of social control by all-butomnipotent federal agencies. ${ }^{72}$

The EPA's behavior fits several elements of our definition of "due process" social control. The 400 meetings they held across the country to promote their proposed new rule along with their social media blitz are examples of mechanisms in the form of patterns of pressure to maintain the agency's internal interpretation of their desired normative social order and cohesion. The GAO officially ruled that the EPA's actions were illegal, meaning that the EPA used coercion as one of their mechanisms of social control. Due process in the United States is overseen by the checks and balances set out in the United States Constitution. However, even "due process" social control by a United States government sanctioned agency can involve coercion, force, and restraint via their authorized enforcement duties. Should the EPA act in the manner in which agricultural stakeholders anticipate, that of obtaining permits prior to moving soil for stock tanks or irrigation purposes, the EPA would likely use force and restraint, an

\footnotetext{
${ }^{72}$ Proposed activities that are subject to the rules of the EPA are regulated through a permit review process. An individual permit may be required for potentially significant impacts. Individual permits are reviewed by the U.S. Army Corps of Engineers which evaluates applications under a public interest review, as well as the environmental criteria set forth in the Clean Water Act Guidelines, regulations promulgated by EPA. In addition to jointly implementing the Clean Water Act Section 404 program, EPA and the U.S. Army Corps of Engineers (Corps) share Section 404 enforcement authority.
} 
obvious mechanism of "due process" social control, to enforce the regulations. In fact, they have enforced by restraint often in their history. Although, the EPA claims in their extensive press releases that no farmer should worry about a permit to move dirt around in his irrigated fields or expand their stock tanks, the EPA's actions overrule their claims in one particular case now pending in the United States federal courts.

The case is known as the United States Army Corps of Engineers . Hawkes Co., Inc., in the United States Court of Appeals for the $8^{\text {th }}$ Circuit, docket number 15-290. According to Miriam Siefter, an Assistant Professor of Law at the University of Wisconsin Law School writing in Scotusblog (the Supreme Court of the United States blog):

In this case, respondent Hawkes Co. wishes to mine peat on a wetland property in Minnesota. (Peat is ultimately used, among other purposes, to construct golf greens.). In 2010, Hawkes applied for a permit from the corps. In 2011, the Corps issued a letter containing a "preliminary determination" that the property contained jurisdictional waters. The nearest traditional navigable water, the Red River of the North, is 120 miles away, but the Corps asserts that the wetlands in question are connected to that river by culverts, unnamed streams, and another river. After a series of further meetings and site visits, in 2012 the Corps issued an "Approved Jurisdictional Determination" (JD) confirming that the property contained waters of the United States. Hawkes's complaint alleges that, during this time, corps employees stated that the permit process would be very lengthy and expensive, and that one corps representative told a Hawkes employee that "he should start looking for another job." Hawkes administratively appealed the JD pursuant to Corps regulations. After oral argument, a 
review officer issued a written decision in Hawkes's favor, concluding that the administrative record did not support the JD. On remand, the Corps revised the JD but again concluded that the property contained jurisdictional waters. The revised JD noted that the wetlands on the property contain significant biodiversity, are of "exceptional quality," and have a significant nexus with the Red River of the North. ${ }^{73}$

Notwithstanding the publicized position taken by the EPA that their intent in promulgating the "Waters of the United States Rule" was not to stop farmers from their daily activities, this case clearly demonstrates the EPA's intent to exert their authority 120 miles away from the farmer's land using the theory of the conjunctive relationship of the geological containers of water. ${ }^{44}$ An amicus curia brief (friend of the courts brief) was filed on March 2, 2016 by the California Farm Bureau Federation, California Cattlemen's Association, and others. Peter Prows, counsel of record wrote in support of Hawkes the defendants:

The Clean Water Act is a penal statute, imposing potentially ruinous criminal sanctions and civil penalties on landowners accused of violating it. Due process requires that penal statutes "define the criminal offense with sufficient definiteness that ordinary people can understand what conduct is

${ }^{73} \mathrm{http://www.scotusblog.com/2016/03/argument-preview-diving-into-finality-issues-under-the-clean-water-}$ act/ March 24, 2016.

${ }^{74}$ The three geological containers of water are surface water (water that exists in a watercourse), groundwater (water underground in pools or aquifers), and diffused surface water (water that runs across land before entering a surface watercourse or into the ground to become groundwater). These geological containers relate to each other conjunctively; surface water feeds groundwater and vice versa; diffused surface water feeds surface watercourses and groundwater. A water molecule traveling through the hydrogeological cycle, is like a chameleon, it changes geological containers at will as it seeks sea level. 
prohibited and in a manner that does not encourage arbitrary and discriminatory enforcement."

But ordinary people have practically no way of understanding in advance whether their activities would violate the Act, or lead to arbitrary or discriminatory enforcement by the Government or other private parties. The Corps' litigation position would make this constitutional problem even worse.

The Corps' regulations prescribe that approved jurisdictional determinations (JDs) are "final agency action", and the corps has explained that the public can "rely on" them. But here, the corps argues that approved JDs are not final agency action, and they should not be relied on. It even takes the position that landowners who rely on an approved JD, and are careful to avoid any property identified as jurisdictional, can still be subject to penal enforcement action if the corps or any member of the public later asserts that additional jurisdictional areas exist on the property. This only adds to the uncertainty that the Act imposes on landowners. To help mitigate the constitutional problem that this uncertainty would present, this court should interpret "final agency action" to include approved JDs. ${ }^{75}$

The dispute is over the jurisdiction of the EPA under the Clean Waters Act. Hawkes rightly applied for a permit to dig the peat in an undisputed wetlands area. The corps of Engineers issued an "Approved Jurisdictional Determination" (JD) which Hawkes disputed successfully in an administrative hearing with a Corps review officer. The JD was revised but

\footnotetext{
${ }^{75}$ UNITED STATES ARMY CORPS OF ENGINEERS, Petitioner, v. HAWKES CO., INC., et al. Respondents. On Writ Of Certiorari To The United States Court Of Appeals For The Eighth Circuit — BRIEF FOR CALIFORNIA FARM BUREAU FEDERATION, CALIFORNIA CATTLEMEN'S ASSOCIATION, CALIFORNIA BUILDING INDUSTRY ASSOCIATION, BUILDING INDUSTRY LEGAL DEFENSE FOUNDATION, \& CALIFORNIA BUSINESS PROPERTIES ASSOCIATION AS AMICI CURIAE IN SUPPORT OF RESPONDENTS — PETER PROWS Counsel of Record BRISCOE IVESTER \& BAZEL LLP 155 Sansome Street Seventh Floor San Francisco, CA 94104 (415) 402-2700 pprows@briscoelaw.net. March 2016.
} 
still concluded the peat bog was under the jurisdiction of the United States Corps of Engineers. Hawkes strongly objected to this JD and sought relief in the federal court. According to their petition written by counsels Mark Mill and M. Reed Hopper:

The Administrative Procedure Act "creates a presumption favoring judicial review of administrative action." Sackett v. Envtl. Prot. Agency, 132 S. Ct. 1367, 1373 (2012). That presumption applies in this case. Like the Sacketts, Hawkes is subject to agency strong-arming under the law. The facts show the wetlands on Hawkes' property are not jurisdictional under the Clean Water Act. But the Corps has erroneously determined otherwise through a final and legally binding Jurisdictional Determination (JD). Hawkes can take no action without incurring exorbitant expense and delay. Seeking a permit will cost hundreds of thousands of dollars and months or years in review. Proceeding with the project without a permit will subject Hawkes and its officers to both civil and criminal liability with potential fines of $\$ 37,500$ per day and the risk of incarceration. Even taking noaction is prohibitive because it means an end to the proposed project and Hawkes' economic viability. ${ }^{76}$

The petition indicates an example of "due process" social control by mentioning the civil and criminal penalties at risk for Hawkes in the incredible amount of $\$ 37,500$ per day plus the risk of incarceration. "Due process" social control, though strongly disputed in this federal case, can include the statutorily sanctioned right of enforcement of an agency rule. Here again the federal courts are a part of the checks

\footnotetext{
${ }^{76}$ UNITED STATES ARMY CORPS OF ENGINEERS, Petitioner, v. HAWKES CO., INC., et al., Respondents. On Petition for Writ of Certiorari to the United States Court of Appeals for the Eighth Circuit. Docket Number 15-290.
} 
and balances contemplated by the United States Constitution and can establish a vital precedent that could have both intended and huge unintended consequences for the agricultural business across the United States.

On Tuesday May 31, 2016 the United States Supreme Court issued a ruling on the Hawkes case. According to Wall street Journal reporter Brent Kendall, "The Supreme Court on Tuesday made it easier for landowners to contest the federal government's ability to regulate their property under the Clean Water Act."77 The limited issue in this Supreme Court's ruling was whether Hawkes could bring suit before exhausting the US Army Corps of Engineers' permitting process. The court ruled in favor of Hawkes to allow the Hawkes suit to proceed without completing the permit process. ${ }^{78}$

The Court's opinion began with an abstract of the prior jurisprudence process of the case. The US Army Corps had rendered a "jurisdictional determination" (JD) that the Hawkes' property was within their regulatory jurisdiction. Had they not issued the JD, it is likely that Hawkes would have been denied their "day in court" until at least this most basic question was answered: Did the Corps have any

\footnotetext{
${ }^{77}$ Brent Kendall. The Wall Street Journal. May 31, 2016.

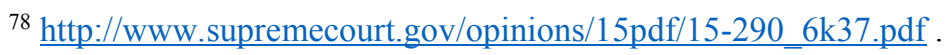


regulatory authority over the Hawkes' activities? Chief

Justice Roberts reported this detail,

Respondents [Hawkes], three companies engaged in mining peat, sought a permit from the Corps to discharge material onto wetlands located on property that respondents own and hope to mine. In connection with the permitting process, respondents obtained an approved JD from the Corps stating that the property contained "waters of the United States" because its wetlands had a "significant nexus" to the Red River of the North, located some 120 miles away. After exhausting administrative remedies, respondents sought review of the approved JD in Federal District Court under the Administrative Procedure Acting that the revised JD was not a "final agency action for which there is no other adequate remedy in a court," 5 U. S. C. \$704. The Eighth Circuit reversed. ${ }^{79}$

The Corps claimed that even though they issued the JD, Hawkes had not fully completed the permit process. Why then should the matter be questioned at this time?

Chief Justice John Roberts, author of the Court's opinion, used the Corps' own previous testimony to support the Court's basic reasoning in the decision, "As Corps officials indicated in their discussions with respondents, the permitting process can be arduous, expensive, and long."80 The reality of Hawkes' precarious position was simple: if they had to go through the entire permit process in order to

\footnotetext{
${ }^{79}$ Opinion. 1.

${ }^{80}$ SUPREME COURT OF THE UNITED STATES. No. 15-290. UNITED STATES ARMY CORPS OF ENGINEERS, PETITIONER $v$. HAWKES CO., INC., ET AL. . ON WRIT OF CERTIORARI TO THE UNITED STATES COURT OF APPEALS FOR THE EIGHTH CIRCUIT. Opinion of the Court, 578 U. S. (May 31, 2016). 9 .
} 
then file suit, the economic burden of such would deny them justice. Six of the Supreme Court justices concurred with the Opinion "with Justice Ruth Bader Ginsberg joining in with "most of it." 81 The message the court sent to the Corps was an all but unanimous ruling offering one highly significant comfort to the citizens of the United States: that being "justice" based on reality, not obscure and confusing legal language, remains, at least in this matter, a cherished social value.

Perhaps the final comment made by Chief Justice Roberts

is the most telling,

Finally, the Corps emphasizes that seeking review in an enforcement action or at the end of the permitting process would be the only available avenues for obtaining review "[i]f the Corps had never adopted its practice of issuing standalone jurisdictional determinations upon request. True enough. But such a "count your blessings" argument is not an adequate rejoinder to the assertion of a right to judicial review under the APA. 82

Clearly it is the EPA's duty to protect our waters under the Clean Water Act and the first question that must be answered is the jurisdictional question, how far does the EPA's jurisdiction go? The EPA has all legal rights to

\footnotetext{
${ }^{81}$ Brent Kendall. The Wall Street Journal. May 31, 2016.

${ }^{82}$ Opinion. 10.
} 
propose their jurisdictional boundaries and the public has an equal right to dispute the proposal in our courts of law. of course all reasonably thinking citizens would applaud any agency or person trying to protect our national water quality. However, using illegal tactics such as the EPA has been declared guilty of by the Government Accounting Office to promulgate any rule without following the due process of law, proves the EPA's intent was much more than mere protection of our water; it was a pronounced effort at "due process" social control using water as a weapon. There are countless other examples of the disputes between the central government and its member states in the United States over water policy. Most scholars of water policy are in general agreement that the US EPA is the agency that most affects state sovereignty over water. Many lawsuits are pending in the United States currently that may someday better define the limits and boundaries of water policy jurisdiction. Unfortunately, it seems to me from decades of scholarly observation that only the courts will offer remedy and relief in this debate as the United States Congress simply fails to exercise their rightful guidance. Congressional hearing after congressional hearing on water issues seem only to offer a forum for complaints, responses to public opinion, and politics, resulting in little if any workable legislative 
guidance. The debate over the boundaries between state and federal government jurisdiction in water issues, arguments over the issue of sovereignty, will continue for years to come. It is clear that at least half of the states in the United States are standing ready to meet the federal government in the courts to "draw the lines on the map" of sovereignty.

Cases completed by judgments in the United States Federal Courts indicate the activity of the US in exerting their supra-legal authority over its member states in the "Environmental" category. Water disputes are placed into the Environmental category. I chose only the civil cases as this study only involves civil policy matters not criminal matters.

US federal cases resulting in judgment (civil) involving federal environmental laws. $\underline{2010} \quad \underline{2011} \underline{2012} \underline{2013} \underline{2014}$ $\begin{array}{llllll}\text { Environment (Total US) } & 277 & 183 & 186 & 151 & 143\end{array}$

$\begin{array}{llllll}\text { Environment (Texas only est.) } & 26 & 15 & 13 & 10 & 7\end{array}$

Figure 1. US Federal Court Judgments Rendered Concerning the Environment 2010-2014

Figure 1 above shows 71 estimated Texas environmental cases over this 5 year period that resulted in a judgment. 83 Texas

\footnotetext{
${ }^{83}$ From “United States Attorneys' Statistical Reports 2010, 2011, 2012, 2013, 2014”. https://www.justice.gov/usao/resources/annual-statistical-reports . Accessed May 5, 2016. The US Attorneys'
} 
is, disproportionally when compared to the 50 states of the United States, either the plaintiff or defendant in civil lawsuits in the federal courts; if the distribution was equal across the United States, Texas' share would only be 2\% per year. However, due to Texas' size, population, and the nature of one of its major businesses, that of oil and gas exploration, refining, and chemical refining along the Gulf Coast, it is somewhat understandable Texas would be more involved in federal environmental judgments. For the purposes of this study, in comparison to spain and its relationship with the EU courts and EU enforcement of its supra-legal authority, it does indicate Texas has almost 2.5 times (71 in the case of Texas, 29 in Spain ${ }^{84}$ ) as many civil judgments stemming from federal lawsuits than spain does from their relationship to the EU Court of Justice. The supralegal authority of the federal government in the United States has been in place since 1788 upon ratification of the U.S. Constitution and in Texas since 1845 when Texas first joined the union. This supra-legal authority was disputed to one degree or another, even to the point of a terrible civil

reports do not separate Environmental judgments by state, only by total nationwide in all federal courts. Therefore, I estimated the amount of Environmental judgments in Texas by taking the percentage of all Texas civil cases that resulted in a judgment of total civil cases that resulted in a judgment nationwide. The percentages calculated for Texas were 2010 9.6\%, 2011 8.1\%, 2012 7.1\%, 2013 6.5\%, 2014 4.9\%.

${ }^{84}$ See Figure 2 in this study. 
war between 1861 and 1865, continuously since 1788 and likely will continue for many years to come. The laws involving these judgments are not "directives" such as in the EU, but laws with huge dollar enforcement penalties and damages. The EU is a much younger central government. It will be interesting to see if over a similar 220 year period to the United States, if the EU will gradually claim increasing supra-legal authority as the United States has.

\section{The Supra-Legal Debate in Spain - Environmental Law and the European Union}

The European Union came into existence from a series of international treaties beginning in 1957 with the Treaty Establishing the European Economic Community that formed the first pillar of the community, that of economic integration. In 1987 the Single European Act was ratified in 1987, the Maastricht Treaty or "Treaty on the European Union" was ratified in 1993 followed by other subsequent treaties and agreements. The Maastricht treaty established the second and third pillars of the community of common foreign and security policy and enforcement and cooperation in criminal matters. ${ }^{85}$ These treaties are examples of "diplomatic" social control through which "due process" social control mechanisms were created.

${ }^{85}$ Louka. 40. 
Legal scholar Molly Hall characterized the European

Union (EU) as "a supranational, treaty-based organization

consisting of four central institutions: the European

Commission, the European Parliament, the European Council of

Ministers, and the ECJ [European Court of Justice]."86 Ms.

Hall opined:

Up until the last eight years [1999-2007], Europeans had issued a great deal of environmental legislation, but had balked at thorough-going enforcement of those laws. Since 1998 however, the EU has taken three significant steps that signal a willingness to enforce EU environmental laws: judicial enforcement with the threat of sanctions; central coordination of inspections and monitoring; and new legislation on public access to environmental information. 87

The Court of Justice of the European Union is the supreme legal body of the EU and has jurisdiction to:

- Review the legality of institutional actions of the EU;

- Ensure that EU member states comply with their obligations under EU law; and,

- Interpret EU law at the request of national courts and tribunals.

According to the Court of Justice of the European Union:

The primary task of the court of Justice as the legal order of the European Union is to examine the legality of European measures and ensure the uniform

\footnotetext{
${ }^{86}$ Molly Elizabeth Hall. "Environmental Law in the European Union: A New Approach to Enforcement". Tulane Environmental Law Journal. Summer, 2007,20 Tul.Envtl.L.J. 278.

${ }^{87}$ Ibid.
} 
interpretation and application of European Union law... The Court of Justice is composed of 28 Judges and 9 Advocates General. The Judges and Advocates General are appointed by common accord by the Governments of the Member states after consultation of a panel responsible for giving an opinion on the suitability of candidates to perform the duties in question. They are appointed for a renewable term of six years. They are chosen from among lawyers whose independence is beyond doubt and who possess the qualifications required for appointment, in their respective countries, to the highest judicial offices, or who are of recognised competence. 88

Over the years, the court of Justice through its case-law has established itself as the supra-legal authority over member states in areas of jurisdiction that the member states have agreed to by treaty ratification. ${ }^{89}$ The Court of Justice puts their relationship with the courts of EU member clearly,

The Court of Justice also works in conjunction with the national courts, which are the ordinary courts applying EU law. Any national court or tribunal which is called upon to decide a dispute involving EU law may, and sometimes must, submit questions to the court of Justice for a preliminary ruling. The court must then give its interpretation or review the legality of a rule of EU law. 90

\footnotetext{
${ }^{88}$ Court of Justice of the European Union. December 2010 edition. http://curia.europa.eu/jcms/upload/docs/application/pdf/2012-05/cjue en.pdf
}

${ }^{89}$ The terms of all the treaties creating the Court of Justice's authority along with the details of all the laws agreed to and ratified by member states is outside of the scope of this study. Spain voted strong support to the treaties in effect now including the treaties giving the EU a strong claim to authority over Spanish water mostly in through the EU environmental laws. The assumption in this study is that there is no debate that Spain agreed to the general terms of the EU environmental laws. However, the extent of the interpretation and enforcement of those EU environmental laws are in question exactly as the extent of the environmental laws promulgated by the United States Congress is debated in the courts by individual states like Texas.

${ }^{90}$ Ibid. 
EU environmental law is binding and "serves as an

overlay to Spanish domestic law."91 Albert C. Lin, providing

the basics of the water relationship between spain and the

EU, emphasizes,

Binding EU law consists primarily of regulations and directives. EU regulations have binding legal force as soon as they are passed. EU directives, in contrast, require a member state to accomplish specified results but allow the state discretion regarding how to do so. Numerous EU directives govern environmental matters.... ${ }^{92}$

In 2014, 622 new cases were introduced in the court of Justice, 719 cases were completed, and 787 cases were pending.93 The category in which the court of Justice's water authority exists is designated as the "Environment." One hundred thirty-six (136) judgments were issued by the court of Justice involving EU environmental laws from 2010 - 2014 as shown in the figure below: ${ }^{94}$

\footnotetext{
${ }^{91}$ Albert C. Lin. "Fracking and Federalism: A Comparative Approach to Reconciling National and Subnational Interests in the United States and Spain." Environmental Law. Fall, 2014. 44 Envtl. L. 1045.

${ }^{92}$ Ibid.

${ }^{93}$ Court of Justice. Luxembourg, January 1, 2015. "COURT OF JUSTICE OF THE EUROPEAN UNION ANNUAL REPORT 2014 Synopsis of the work of the Court of Justice, the General Court and the Civil Service Tribunal". Luxembourg, 2015. www.curia.europa.eu .

${ }^{94}$ Ibid. 101.
} 
Cases completed by judgments, by opinions or by orders involving a judicial determination - Subject matter of the action (2010-14)

\section{$\underline{2010} \underline{2011} \underline{2012} \underline{2013} \quad \underline{2014}$}

$\begin{array}{llllll}\text { Environment } & 9 & 35 & 27 & 35 & 30\end{array}$

\section{Figure 2. Court of Justice Judgments Rendered Concerning the Environment 2010-2014}

From 2010 through 2014, the Court of Justice issued a total

of 29 judgments (net of dismissals) against spain "concerning failure of a Member state to fulfill its obligations." Of the 29 overall judgments against Spain, 12 were in the "Environment" category or $8.82 \%$ of the total. 95 However, the bulk of the environmental judgments against spain involved "minor" issues such as one as minor as excessive emissions from boilers in buildings or others in the form of "warnings."

For example, in Case C-343/10 European Commission v. Kingdom of Spain, the European Commission claimed Spain failed to meet its obligations under this directive: "Failure of a Member State to fulfill obligations - Directive 91/271/EEC-Pollution and nuisances-Treatment of urban waterArticles 3 and 4 (2011/C 179/08)." The Plaintiff claimed Spain failed to "ensure that urban waste water from the

\footnotetext{
${ }^{95}$ InfoCuria - Case-law of the Court of Justice, List of results. http://curia.europa.eu/juris/documents . Number of Environment category cases was determined by the author's own count after examining all the cases listed.
} 
agglomerations with a population equivalent of more than 15,000 is collected in conformity with Article 3 and 4. The complaint listed 48 "municipalities" by name. Judgment was rendered in favor of the European Commission on April 14, 2011. The only orders were "...the Kingdom of Spain to pay the costs" which are the court costs and legal fees. No penalty for damages to the Plaintiff was assessed. There was little detail available publicly and it appears the judgment was a warning acknowledging Spain's need to bring the waste water treatment in these areas in compliance with the European Union laws. ${ }^{96}$

The environmental laws of the EU are relatively young, dynamic, and still being processed through the national courts and the court of Justice in the typical search for the elusive water policy comfort of "consistency and predictability." The judgments against spain are classified as judgments but do not represent any indication of irresponsibility or deliberate disobedience to EU environmental laws, merely matters of legal clarification and expressions of accountability to new laws promulgated by a relatively new central government. Another mitigating factor may be the success rate of the European Court of Justice in

\footnotetext{
${ }^{96}$ Ibld.
} 
litigation against member states. According to New York Times reporter Steven Erlanger on Britain's loss of 75\% of the 131 cases brought against it in the European Court of Justice, True, at least in part. But the European Commission for example, brings only cases it thinks it can win. And 91 of the cases were brought by the commission because of Britain's failure to put in effect European law, as it is obligated to do. ${ }^{97}$

What must be kept in mind in thinking about the supra-legal authority of the EU over its member states is that the member states voluntarily chose to join and comply with the laws and directives.

How then does the implementation of supra-legal authority by central governments over member sovereign states' public water policies control the three pillars of society in that nation? Central governments control the three pillars of society by using "due process" social control. "Due process" social control exists and is enforced by the due process that evolves from debate in constitutions as in the United States, in treaties as in the European Union where it is given birth by agreement between sovereign member states on "diplomatic" social control, in the development of laws enacted by the authorized legislative branches, by

\footnotetext{
${ }^{97}$ Steven Erlanger. "Money, Jobs and Sovereignty: Myth vs. Reality Ahead of 'Brexit' Vote." New York Times, June 7, 2016.
} 
regulatory agencies' promulgation of rules to enforce the laws, and by the courts' interpretations of the laws and rules. Water policy emerges from the constitutions, treaties, laws, regulations, and court decisions and can dramatically impact the three pillars of society. Without reliable water sources and fair and workable water public policies that are accepted and adhered to by the public, any economy cannot grow or frankly, even survive. Without environmentally sustainable and protected water sources no society can thrive or even survive if the extraction, use, or discharge is not at all times cognizant of the consequences to society's environment. Without fair and workable water public policies that are accepted and adhered to by the public voluntarily, human relationships rapidly deteriorate into chaos.

The choices made by sovereign state governments to allow a central government to have supra-legal authority was indeed a free choice in Spain and Texas. Spain overwhelmingly agreed to join the EU; Texas frankly, did the same in 1845 having all but begged to join the United States in 1837 but was rejected because it would enter as a "slave state." But is it possible for central governments to share authority with their member states over water? 


$$
\text { Yes, through "diplomatic" and/or "due process" social }
$$

control. The current debate in Great Britain about leaving the EU commonly known as "Brexit" has produced a significant treatise by University of Cambridge Public Law Professor Mark Elliott. According to Elliott, Parliament [the Parliament of the United Kingdom] can be sovereign yet European Law can also be supreme. Elliott describes the fundamental principle of British constitutional law is that the law of Parliament is sovereign. He opines, "Yet the supremacy of European Union law - meaning it takes priority over conflicting laws enacted by Individual Member States - is a basic principle of the EU's legal system." Elliott refers to section 18 of the European Union Act of 2011 in which it is stipulated that "... EU law has effect in the UK only because Parliament, by enacting the 1972 Act [the European Communities Act of 1972], has allowed it to." 98

It is my opinion that Parliament agreed to "diplomatic" social control by ratifying their relationship with the EU and then set up "due process" social control parameters that are dynamic and "living."

\footnotetext{
${ }^{98}$ Elliott, Mark. "If European Union Law is supreme, can Parliament be sovereign?" Public Law for Everyone blog. http://publiclawforeveryone.com/2016/02/21/1000-words-if-european-union-is-supreme-can-parliamentbe-sovereign/ . Accessed 04/03/2016.
} 
Elliott discusses several key cases in English law that tried to face the issue of sovereignty and arrived at the conclusion that it depends on interpretation by the courts. His ultimate answer is yes, Parliament can maintain sovereignty and still allow certain EU laws to have supralegal authority over some laws in the United Kingdom. The distinction is what I would call a "boundary" issue between domestic law and international law. Jurisdiction must be specific and explicit and worked out following the "due process" of both Parliament and the EU, both of which United Kingdom authorized representatives have the choice of decision. ${ }^{99}$

Similarly in the United States, Texans authorize members of the House of Representatives and two senators to represent their political will in the United States Congress. Elliott sums up astutely the manner in which it can be applied in the United States as well,

The upshot is that, for as long as the UK remains a Member state of the EU, parliamentary sovereignty still exists, but it is unlawful- as a matter of EU and international law- for sovereignty to be exercised in ways that are incompatible with EU law.

As long as Texas is a member of the United States, Texas sovereignty exists but Texas cannot exercise its sovereignty

\footnotetext{
${ }^{99}$ Ibid.
} 
in ways that are incompatible with federal law. That is precisely why we have a system of government in the United States that has "checks and balances" or three branches of government that hold veto or other power over the decisions and actions of the other branches. In fact, this is the key to the long term life of the United States as an ongoing concern. As long as social control is exercised following "due process" then the best possible chance is given to survival of both member states and central governments. Central governments and member states governments then share the duty and responsibility of maintaining, protecting, and respecting the three pillars of society for all because they freely chose to create the governments following "due process" in whatever unique terms chosen. Water as the most basic ingredient of life can be protected by member states and by the central government. Water policies and laws can and do set out jurisdictions for control and the boundaries of these jurisdictions are determined in great tension. It has been accepted in the United States for over two centuries that a dispute between two or more member states only court of jurisdiction is the federal courts with the ultimate jurisdiction being the United States Supreme Court. This is not necessarily so for disputes over local government issues in a state like Texas. Certainly there can be a federal law 
that supersedes local law such as the various United States Civil Rights Acts for example, but the use of these laws in local matters are under constant debate in the courts, again following due process.

My first hypothesis, that the three pillars of society can be controlled by the supra-legal authority of central governments over member sovereign states' public water policies proves true without doubt. Central governments are given authority by the people and in the case of Texas in the United States and Spain in the European Union, free choices were made to honor laws and regulations set by the central governments. There will be a continuing debate over the extent of EU authority over its member states, but "diplomatic" social control as a result of treaty negotiations and ratification set up "due process" social control. Likewise there will be continuing highly controversial debate over the extent of the United States authority over its member states, but the over 200 year old US Constitution sets out through checks and balances the limits of federal authority and offers the US citizenry a path to modify and revise at all times under "due process" social control. 


\section{A Local Central Texas Example of "Due Process" Social Control That Worked}

In 2014, a hotly debated central Texas controversy over groundwater transfer occurred resulting in a fine example of "due process" social control honoring the processes set out in the U.S. Constitution and the Texas Constitution. As heretofore mentioned, groundwater in Texas is owned by the surface landowner and as such is allowed to be sold, leased, or otherwise disposed of outside the transfer of overall title to the land. Water rights can also be permanently severed from the land in a separate transaction in Texas and has been done since the mid-1700s.

A private water marketing company, Electro Purification negotiated a contract to provide water to the city of Buda and other water users sourced from groundwater in the vicinity of the city of Wimberley, Texas located thirty miles or so south of Austin, Texas. The company negotiated leases and sales of water rights from a handful of local ranchers in the area. An odd quirk was discovered and/or claimed by the company in the groundwater regulatory jurisdiction for the aquifer that would become the source for the contracts. The public around Wimberley generally thought that their groundwater, mostly drawn from the Trinity Aquifer, was regulated by either the Edwards Aquifer Authority (EAA) or 


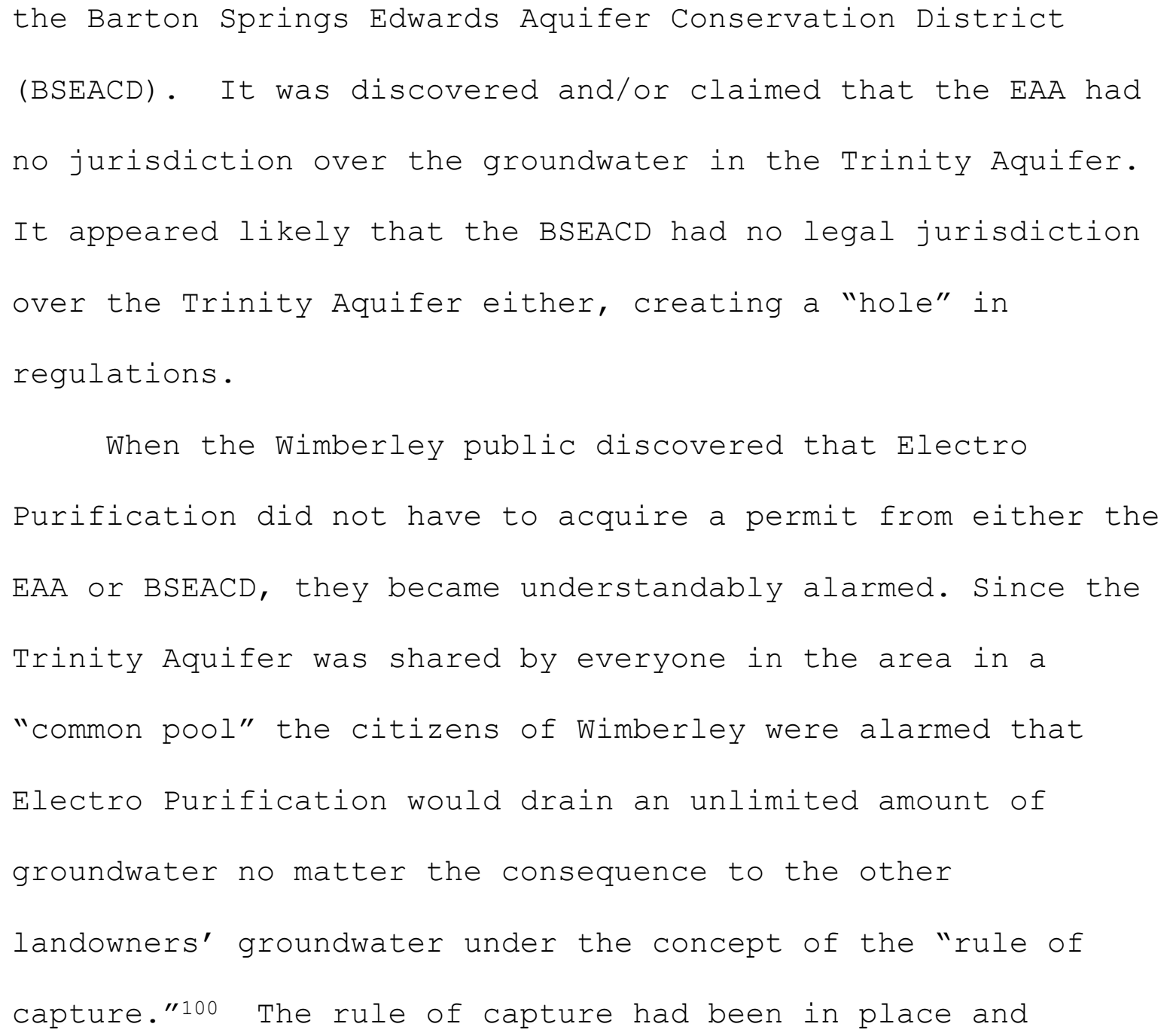

\footnotetext{
${ }^{100}$ The roots of the "rule of capture" are found in the ancient idea that the ownership of wild game could not be claimed until possession was actually taken. "The rule of capture" is one of the most confusing and for some, most reviled concepts in Texas water law today.

The "rule of capture" as it pertains to groundwater states that a land owner who drills water wells on his or her land can pump all the water from underground that can be "captured" without any liability for damage to any neighboring property owner. If the land owner does not waste the water from the well, dig the water well to intentionally harm a neighbor, or cause subsidence, even if the neighbor's water well dries up completely as a result, the neighbor has no claim for compensation or damages against the land owner.
}

The "rule of capture" does not recognize correlative rights between landowners in pumping groundwater, and the Texas courts have consistently upheld this rule for over a hundred years. See W.A. East v. the Houston and Central Texas Railway, 1904. Also see Charles Porter, "The History of W.A. East v. Houston and Texas Central Railway Company, 1904: Establishment of the Rule of Capture in Texas Water Law or 'He Who Has the Biggest Pump Gets the Water"' in the $50^{\text {th }}$ Anniversary Issue of the East Texas Historical Journal, Fall, 2012. This article won the Chamberlain Award for the best journal article of 2012. 
confirmed as legitimate time and again by the courts for over one hundred years in Texas. Commonly known as "he who has the biggest pump gets the water," the rule of capture allowed any landowner to pump all the groundwater they wanted, even if they drained their neighbors' groundwater to the extent that the neighbors' wells dried up. The only restrictions to the rule of capture are:

1. No one can maliciously take groundwater from a neighbor;

2. No one can waste groundwater;

3. No one can cause land subsidence ${ }^{101}$ when taking groundwater; and,

4. If the surface land is within the jurisdictional boundaries of a groundwater conservation district or other authorized groundwater regulatory district, then the districts have the right to regulate the spacing of groundwater wells, the amounts drawn from the groundwater pool, and allocate the amount of groundwater transferred outside the district, all through a public hearing process.

101 "Subsidence" means the lowering in elevation of the land surface caused by withdrawal of groundwater. See Texas WATER CODE, TITLE 2. WATER ADMINISTRATION, SUBTITLE E. GROUNDWATER MANAGEMENT, CHAPTER 36. GROUNDWATER CONSERVATION DISTRICTS, SUBCHAPTER A. GENERAL PROVISIONS, SEC. 36.001. DEFINITIONS. 
If the Trinity Aquifer was truly outside the

jurisdiction of any regulatory agency, then Electro

Purification could take any amount of water and sell it or

lease it to anyone they wanted without liability to any other

landowner sharing the aquifer water.

The people of Wimberley gathered together in "due

process," formed groups, filed a lawsuit, and sponsored a

bill in the $84^{\text {th }}$ Session of the Texas Legislature to correct

the regulatory oversight. Dr. Patrick Cox, a well-known

civic leader and historian, led the group from Wimberley in

the legislative process that resulted in the enactment of

House Bill 3405102, subsequently correcting the oversight in

the regulation of the Trinity Aquifer in the area. ${ }^{103}$ The

bill as passed modified the jurisdiction of the BSEACD to

include the Trinity Aquifer.

The emotions ran strongly on all sides. The citizens of

the Wimberley area had every right to be worried about their

groundwater being shipped elsewhere; their land values and

way of life depended upon the use of the groundwater. Yet

\footnotetext{
${ }^{102}$ See the entire bill's history and final passed language at http://www.capitol.state.tx.us/BillLookup/History.aspx?LegSess=84R\&Bill=HB3405

${ }^{103}$ See the online journal Policy: Water, Government, and the People. https://texaswaterpolicy.org/2015/02/ Patrick Cox, Ph.D. "Our Water and the Threat to the Heart of Our Existence". February 3, 2015. Dr. Cox artfully describes the Wimberley issues over transfer of groundwater.
} 
instead of using "deceptive" or "destructive" social control tactics, they used the constitutional due process to protect their rights. The actions of the Wimberley citizens in the dispute followed due process, not without controversy and angst, but the system worked. Whether or not Electro Purification will gain an adequate permit to transfer the water they leased or bought from other ranchers in the area is still unknown, but the due process system of government worked. The lawsuits were dropped and the permit process has begun. This is the finest and most recent example of "due process" social control in public water policy formation. "Due process" social control takes time however, sometimes so much time that the potential threat or issue dissipates. Water transfers out of district as proposed in the Wimberley area are prime examples of proposed transactions that are known as "time is of the essence."104 The time of due process in the United States and around the globe is a critical factor in workable public water policies. When the process is not "timely" then justice can be denied to all parties involved. Cities usually cannot wait from

\footnotetext{
104 "Time of the essence means that the performance by one party to the contract at a specified location, date and time is required for the performance by the other party to the contract, and a failure to perform by the time specified will be a breach of the contract. This clause requires that all references to specific dates and times of day noted in the contract should be interpreted exactly in the same manner. Generally, the date set forth in a contract for closing of title is an estimated date and may often be delayed by either party without penalty. Time of the essence clauses can work to the advantage as well as disadvantage of both the parties." From http://definitions.uslegal.com/t/time-of-the-essence-clause/.
} 
years of due process to slake their thirst for immediate water, especially in droughty regions such as Texas and Spain. 


\title{
Chapter Five
}

\section{"Due Process" Social Control: Timeliness of Jurisprudence and the Fair Market Valuation in Water}

\author{
The world's water problems are due to bad governance \\ not physical scarcity. \\ M. Ramón Llamas et al.105
}

\begin{abstract}
My second hypothesis is that the three pillars of society can be controlled by the length of time it takes courts to resolve conflicts in public water policy. How does the lack of timely court rulings on public water policy conflicts change and control the three pillars of a society? The two most significant challenges in the jurisprudence process of water policy in both Texas and Spain are the timeliness of the adjudication process and the credible determination of the fair market value of water. An integral part of the bad governance mentioned in the highlighted quote from Llamas is a water jurisprudence system that does not
\end{abstract}

\footnotetext{
${ }^{105}$ Lucia De Stefano and M. Ramón Llamas, ed. Water, Agriculture and the Environment in Spain: can we square the circle? London, Taylor \& Francis Group, 2013. 1.
} 
deliver timely rulings in civil and administrative court cases. Another inextricably linked part of water governance is an acceptable method to determine the market value of the water in dispute. The market value of water is heavily influenced by the adjudication process of regulations and judicial oversight in the courts. For example, the permit regulations and the permitting process for use of water controls much of the end fair market value of water. In much the same manner, the adjudication process and judicial oversight is heavily influenced by the end market value of water. The market value of water influences the legislative process of water laws and the regulatory agency permit processes since the incentive of the citizenry to pursue changes in water policy through administrative or court hearings is based on the financial risk and reward of the outcome of the judicial process. Since one of the three pillars of any society is its economy, that society must agree on a formula to find the fair market value of water in the courts in consideration of damages owed by an offending party, in taxation, and in real property valuation.

"Justice delayed is justice denied." The origin of this well-known phrase is attributed to William Gladstone, a famous British statesman who served as Prime Minister four 


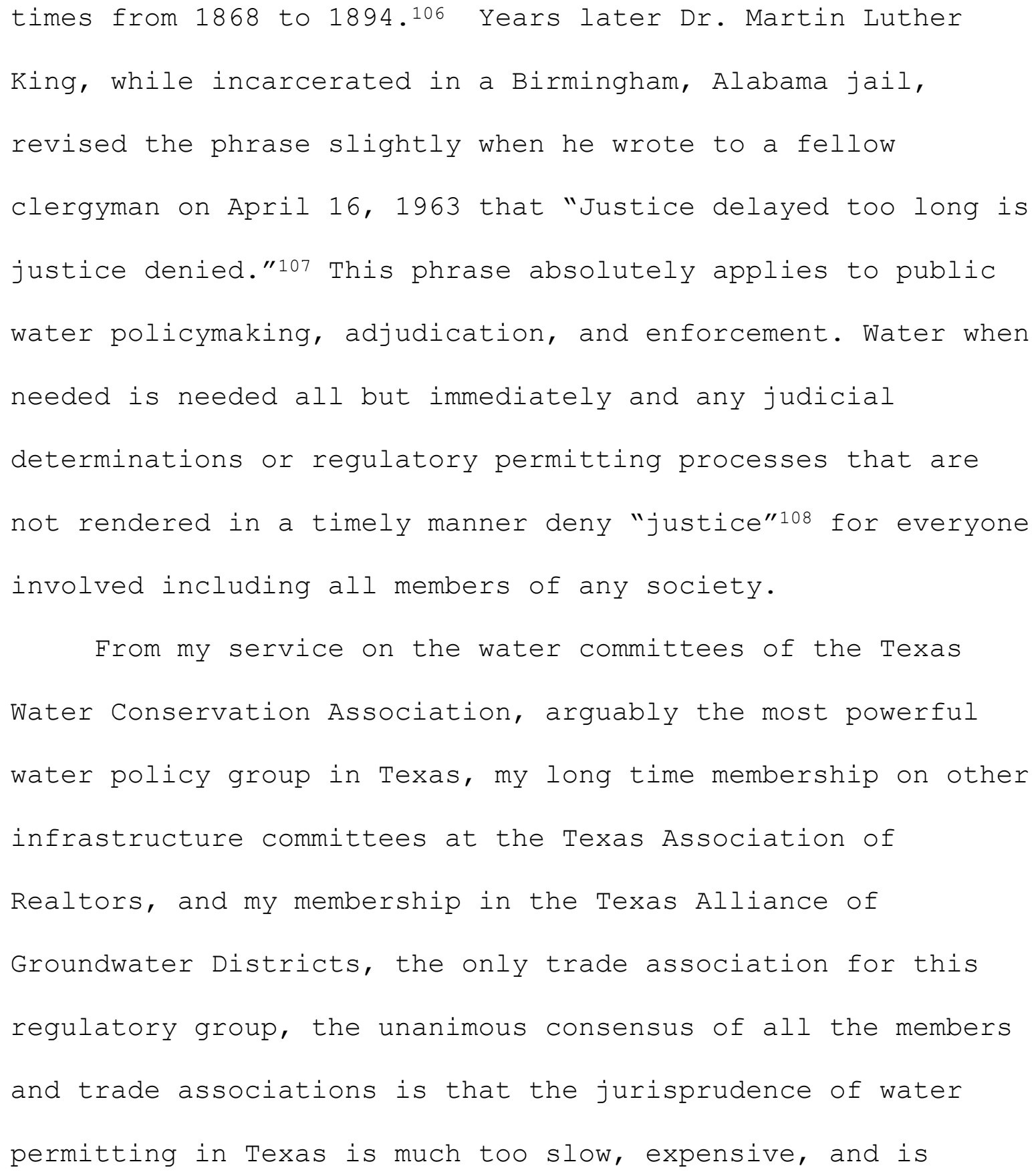

\footnotetext{
${ }^{106}$ For a wonderfully in depth study of Gladstone see Ruth Clayton Windscheffel. Roger Swift. Roland Quinault eds. William Gladstone: New Studies and Perspectives. Farnham, U.K.. Ashgate Publishing, 2012.

${ }^{107}$ For the complete text of the letter posted by the African Studies Center of the University of Pennsylvania, please see http://www.africa.upenn.edu/Articles_Gen/Letter_Birmingham.html .

108 "The quality of being fair and reasonable." Public water policy across the entire spectrum must be above all else fair and reasonable.
} 
detrimental to fair water policy for the state. Spain sets a long time example of timely jurisprudence in water disputes.

The Timeliness of the Jurisprudence of Water in Spain

\author{
Spain has a centuries-long history of recognition of the \\ consequences of "justice delayed" best demonstrated by the \\ Tribunal de las Aquas de las Vega de Valencia, or Water \\ Tribunal of the Valencia Plain109 or Tribunal of Waters at the \\ Gate of the Apostles of the Cathedral of Valenciallo which has \\ been adjudicating irrigation disputes since, some experts \\ say, from the $8^{\text {th }}$ century. ${ }^{111}$ Today the jurisdiction of the \\ Tribunal covers an area of roughly 17,000 hectares ${ }^{112}$ home to \\ 8 acequia madresil3 absolutely critical to the agricultural \\ economy of the traditionally dry region.114 According to \\ Julia Hudson-Richards and Cynthia Gonzales discussing the \\ area, \\ We see a long tradition of agricultural growth, and \\ extended history of market-oriented agriculture, and,
}

${ }^{109}$ Julia A. Hudson-Richards and Cynthia A. Gonzales. "Water as a Collective Responsibility: The Tribunal de las Aguas and the Valencian Community." Bulletin for Spanish and Portuguese Historical Studies, Journal of the Association for the Spanish and Portuguese Historical Studies, 2013. Vol 38: Iss. 1, Article 6. 95.

110 Thomas Glick "Irrigation and Society in Medieval Valencia", Cambridge, Mass. The Belknap Press of Harvard University, 1970. 65.

111 Julia A. Hudson-Richards and Cynthia A. Gonzales. 98.

${ }^{112}$ A "hectare" equals 2.47 acres, hence 17,000 hectares equals approximately 42,000 acres or almost 66 square miles.

${ }^{113}$ An acequia is an irrigation canal; an acequia madre is the main canal or "mother canal" from which many lateral or smaller canals spring.

${ }^{114}$ Julia A. Hudson-Richards and Cynthia A. Gonzales. 100. See also Thomas Glick "Irrigation and Society in Medieval Valencia", Cambridge, Mass. The Belknap Press of Harvard University, 1970. 
perhaps, most importantly, a history of people concerned about and involved with the success of these systems.115

Spain served as a key granary for the Roman Empire making the agricultural tradition of the area one of the longest in history. The irrigation systems may be over 3,000 years old. Glick observes that in Valencia and Castellón water and land were inseparable and water rights could not be severed from the land and sold on the open market, as opposed to Alicante, Elche, and other southern huertas ${ }^{116}$ where water rights could be sold apart after severance from the land much like in early Villa San Fernando (today's San Antonio, Texas). ${ }^{117}$ In the extensive research I conducted for my book Spanish Water/Anglo Water, the earliest original deed trading water rights by severing those rights from the land along the san Antonio River occurred on March 23, 1782 in a transaction between Juan Montes and Juachin Flores; a later transaction was made on August 9, 1800 in which Antonio Armas sold of three hours of his water rights to Francisco Amangual and the land corresponding to that right to José Bustillos.118

115 Julia A. Hudson-Richards and Cynthia A. Gonzales. 100.

${ }^{116}$ Garden, orchard, or produce farm.

117 Glick 1970. 12-13.

118 Porter. Spanish Water/Anglo Water. 64-65. 
The differences between water rights under Spanish law

was as much based upon customary laws (those unique to

certain areas) as they were overall spanish law. In another

treatise written by Glick he suggests,

The stipulations of the Recopilación had little

practical effect; therefore to tediously argue their

meaning is a waste of time. The actual rules and norms

governing the structure of irrigation rights can only be

determined by the systematic study of actual titles and

other documents, such as records of litigation, which

can provide information of how water was apportioned in

reality... Irrigation rights were controlled aby a

constantly evolving process which sought to adjust the

supply of water to demand, both of which could change over time.119

One of the geniuses of the spanish system of law was the trust the Crown placed in competent local officials who are, according to Glick, "...assigned in the promotion of stability within the system."120 Charles R. Cutter, Professor at Purdue University, agreed with Glick in his discussion of derechol21 indiano,

Judicial [Spanish Colonial] administration is still depicted as ponderous, tyrannical, arbitrary, and corrupt. Clearly, many scholars have failed to appreciate the essential qualities of derecho indiano. A

\footnotetext{
119 Thomas Glick. "Irrigation Rights and the Limits of Civil Law in the Spanish Legal Tradition (with Reference to the Southwestern United States". III Conference on water law and administration. December, 1989. 5 .

${ }^{120}$ Ibid.

${ }^{121}$ Charles R. Cutter. "Community and the Law in Northern New Spain". the Americas. Journal of the Academy of American Franciscan History. Vol. 4, April 1994. 467-480. "derecho" according to Cutter has no “... exact English equivalent for the Castilian word, though the word 'justice' might come close." See 468 and fn2 468 .
} 
more careful scrutiny of the historical record reveals an intricate legal system that proved to be adaptable to the peculiar needs of the diverse regions of the empire. Local modification of Hispanic law - derecho vulgar was an important element of this flexibility and constituted a legitimate expression of local selfgovernment. ${ }^{122}$

It is my understanding over the past twenty years of intensive study of the Spanish Colonial system in the New World that the Crown in Madrid recognized the uniqueness of each situation across the sea and not only allowed flexibility in order to "stabilize and defend" his holdings but encouraged such flexibility.

Along these lines, even more interesting and supportive of my opinion of the genius of Spanish Colonial legal

doctrine, which must be remembered to have absolutely been in place in a similar manner in peninsular spain at least since the mid-16 ch century and highly applicable or even possibly influenced by the success of the Tribunal de las Aquas, Cutter goes on to argue,

Known as arbitrio judicial, or judicial will, this feature of the system figures as the key to the flexibility of Spanish Colonial legal administration... Largely misinterpreted as mere whimsy or capriciousness, arbitrio judicial allowed Spanish law to be much more than the mechanical application of judicial prescriptions. Through this device, law became a living, organic entity that the local population might mold to meet situations peculiar to the region. This mechanism, as well as others, empowered spanish subjects to modify

${ }^{122}$ Cutter. 467. 
legislation that they deemed to be unreasonable, unjust, or harmful to the community. Locals often played a significant role in shaping the legal culture of a particular region. ${ }^{123}$

It seems to me that the lessons learned by hundreds of years of exposure to Roman, Moorish, and Iberian water regulations and practices have allowed spain to "set the industry standard" so to speak for water law, management, and policy.

The Tribunal de las Aquas is best described in American terms as an alternate dispute resolution process, has dispensed justice in its region likely for over a thousand years and was designed and operated to be sure, due to the vital nature of the immediate need for water to protect fragile agricultural produce, that its process could never be accused of delaying justice. Justice is the overriding goal of the Spanish legal system now and for over 500 years. Each week on Thursday at 11:00 am, a Tribunal hearing takes place which is "without doubt, the oldest existing justice institution in Europe."124 The proceedings are totally verbal, no documentation is offered by the parties to the dispute or by the Tribunal. The Tribunal's proceeding are not confidential, which is a major distinction between the Tribunal hearings and America's most used form of alternate

${ }^{123}$ Cutter. 470.

${ }^{124} \mathrm{See}$ http://www.tribunaldelasaguas.org/en/ for a fascinating outline of this incredible legal icon. 
dispute resolution, mediation. ${ }^{125}$ In the United States there are generally three forms of alternative dispute resolution, alternatives to normal court litigation. These processes are ombudsmanship, mediation, and arbitration.

Mediation has become a required process for each civil lawsuit in Texas (and is required in most other states in the United States) prior to going to trial. Every filed and served civil law suit must go to mediation at least once with a report given to the court by the mediator. The mediator is certified by training so as to be appointed by the court or agreed upon by the parties. ${ }^{126}$ The mediator's goal is to create a safe and neutral environment for the disputing parties to try to settle their dispute. The mediation process is a "laddered" process beginning with information gathering, followed by problem identification, option generation, bargaining and negotiation, reality testing, and if the parties have come to agreement, settlement writing. Mediation settlements are enforceable by the courts. The mediator is only a facilitator - the parties to the dispute determine with the mediator's assistance and support what the problem is, what the options for settlement are, and the

${ }^{125}$ Charles Porter. "Mediate, Arbitrate, Litigate". Texas Real Estate Commission Continuing Education Course \# 04-00-081-8335, 4 hour Student Manual. 3.

${ }^{126}$ I have been a certified mediator for over 24 years and mediate on a pro bono basis. I also have a special certification in family law. 
final settlement agreement. The mediation process is somewhat similar to the Tribunal process as the sessions are officially only verbal proceedings, while supporting documentation may be brought to the mediation, it is not distributed to the parties beforehand (this is being modified in some cases), and whatever notes or other writings are destroyed after the mediation session ends. Only a very brief report is filed with the court. Of course, the settlement agreement makes mediation quite different than the Tribunal process

The most significant difference between mediation and the Tribunal process is that the parties "own" their decision; any decision is at the parties' sole discretion. The Tribunal makes a judgment and decides the dispute after hearing the testimony of the parties. In that regard, the Tribunal is most similar to the American alternate dispute resolution process of arbitration.

The arbitration process is used quite often in the United States and is a documented proceeding. There can be substantial documentation. I have been an expert witness in many arbitration hearings in the United States over real estate or construction disputes and often there is even more documentation for review than in fully litigated court cases. The parties relinquish another level of their ownership of 
the outcome of the dispute as the arbiter or arbitration panel of arbiters rule and make a final decision on the outcome of the dispute. The parties, usually represented by attorneys, can however, choose from a limited list of special rules of the arbitration association giving some element of choice to the parties.

The American arbitration process is only similar to the Tribunal de las Aquas in the regard that it makes a decision that the parties have to abide by. However, the odd thing about the American arbitration system which greatly differs from the Tribunal de las Aquas is that some are agreed to be "non-binding" on the parties. All rulings by the Tribunal are binding to the parties. The parties in American arbitrations also have, in some cases, the right of appeal, a right not available to Tribunal disputants.

In the Tribunal de las Aquas process there are no records kept and there are no appeals. The parties take part in their own name, neither attorneys nor written documents may "be proposed" but the parties may call witnesses and can request a visual inspection germane to the dispute. From the Tribunal's website,

The President and members of the court can ask the necessary questions for better information on the case and, without more proceeding and in the presence of the interested ones, the court deliberates and sentences... The court only recognizes and sentences if the denounced one is guilty or innocent. In this simple way, so 
effective and respected by all the members of an agricultural community, the laborious Valencian people have solved their water problems from the most remote times. There are no lawyers, there are no documents, no long bureaucratic proceedings that delay what constitutes the most elementary of the human rights: justice [emphasis added]. ${ }^{127}$

Notice I emphasize the word "justice" as the Tribunal's most "elementary" work is of "justice." This goal is absolutely congruent with the time-honored tradition of Spanish law, justice for all. Another internationally respected scholar support my respect for Spanish laws' tradition of justice. As mentioned earlier in this study, surface water was owned by the King of Spain held in trust for the people now and in ancient times. In his analysis of Spanish surface water law, the appropriative system of water right grants based on "first-in-time, first-in-right" priority during water shortage periods, Spanish Colonial water expert, the late Michael C. Meyer long time Director of the Latin American Center at the University of Arizona reasoned, It [surface water law] had a more benevolent social purpose. It recognized that unbridled individual ambition would never produce a harmonious society and viewed justice not as a metaphysical abstraction but as an attainable goal. By enshrining the concept of normative restraint, it was clearly designed to check monopoly, limit the influence of irresponsible officials, protect the disadvantaged, and most importantly to encourage equity [emphasis added]. ${ }^{128}$

\footnotetext{
${ }^{127}$ See http://www.tribunaldelasaguas.org/en/ .
}

${ }^{128}$ Michael C. Meyer. Water in the Hispanic Southwest. Tucson: The University of Arizona Press, 1984. 179. 
Meyer's "holistic" view above of Spanish water law concurs

with mine precisely; no one could state it better. Equity and justice must be in place and protected in order for any society to not only flourish but simply to survive in the long term. Now that we have reviewed briefly Spain's traditions in water law in the distant past, a look at modern water policy is necessary.

Spain's leaders in the past thirty years have struggled to establish a variety of reforms in traditional public water policy even to point of the radical decision to take groundwater ownership out of private landowner's hands and place it in the public domain. ${ }^{129}$ The result of such a historically diametrically opposite revision of groundwater ownership130 has been received by the Spanish citizenry in what could best be described as general "civil disobedience". ${ }^{131}$ According to Spanish water rights experts Fornés, de la Hera, Llinas, and Martinez-Santos:

The 1985 reforms of Spain's Water Law put groundwater under public ownership. While this posed an evident change in groundwater rights, the practical implications

\footnotetext{
${ }^{129}$ Juan Maria Fornés, África de la Hera, Ramón Llinas, Pedro Martínez-Santos. "Legal Aspects of Groundwater Ownership In Spain.” Water International. Vol. 32, No. 4, December 2007: 676.

${ }^{130}$ Groundwater was owned by the surface landowner in Spain for centuries. See Charles Porter. Sharing the Common Pool: Water Rights in the Everyday Lives of Texans. College Station: Texas A \& M University Press, 2014. 135. See also Michael C. Meyer. Water in the Hispanic Southwest, 178, 179. Refer to Siete Partidas (Seven-Part Code) Partida 3, Titulo 28, Ley 1 (part 3, title 28, law 1).

${ }^{131}$ Fornés et al. 682.
} 
of the law have not been so significant. The 1985 Water Law did introduce significant changes for those wells drilled from 1986 onwards. However, these were only a very small share of the total. Therefore, the 1985 Water Law left things more or less as they were with regard to pre-existing wells, which are still the overwhelming majority (Moreu, 2002). This non-committed approach on the part of the legislator is sometimes interpreted as a way of escaping potential social and political unrest. ${ }^{132}$

In response to its citizens concerns, the Spanish government appears to me to have entered into a bidding war against itself for several years. ${ }^{133}$ Each new proposal relating to groundwater ownership in response to citizens' concerns resulted in continued failure of public acceptance in many regions. ${ }^{134}$ Since many Spanish citizens seem to be generally ignoring the proposed reforms in groundwater ownership, it appears to me that spain's groundwater policy is fragmented and inconsistent. Some spanish legal experts recently escalated the debate by making constitutional arguments against the reforms. ${ }^{135}$ One of the most important determinants of public water policy is the court system that interprets the law and enforces contracts between parties.

\footnotetext{
${ }^{132}$ Ibid. 677.
}

${ }^{133}$ Ibid. 676-684. The authors discuss the diligent efforts of legislators to respond to the disobedience with yet another offer of management ideas each rejected and virtually ignored rarely enforced due to lack of funding. The authors declare the situation as "very discouraging" and deem "hydrological insubordination" as the Spanish citizenry's continued response to groundwater management and ownership reforms.

${ }^{134}$ Ibid.

${ }^{135}$ Fornés et al. 680. 
These business contracts comprise the "steel reinforcing" inside one of the three pillars of society, the economy of any society. What have scholars who study Spain's judicial system today determined as the judicial system relates to the economy and contract enforcement?

Spain is ranked in the top 20\% of countries, 33rd from 2011-2015 up from 34th in 2006-2010, on the World Bank's "Ease of Doing Business Index", an ongoing index comparing 189 countries worldwide.136 In the 2011-2015 period, the United States ranked $7^{\text {th }} .{ }^{137}$ While Spain's ease of doing business is very good, likely a strong reason the state of Texas has pursued Spanish companies to operate there, according to one scholar, the Spanish judicial system generates high levels of "dissatisfaction" in reference to contract enforcement. ${ }^{138}$ Juan S. Mora-Sanguinetti of Banco de España-Eurosystem asserts,

This situation has not improved in the most recent years. In fact, since 2001 and for the specific case of executions of judgments, the average resolution rate of the first instance courts of Spain (taken as "Juzgados de Primera Instancia e Instrucción") has fallen by more than 25\%. At the same time, the congestion rate and the pendency cases rate of the same courts have increased by more than 33\%. These facts are certainly disturbing once we take into account that the judicial system is an

\footnotetext{
${ }^{136}$ http://data.worldbank.org/indicator/IC.BUS.EASE.XQ .

${ }^{137}$ Ibid.

${ }^{138}$ Juan S. Mora-Sanguinetti. "A Characterization of the Judicial System in Spain: analysis with formalism indices”. Economic Analysis Law Review. EALR, V. 1, nº 2, p. 213-240, Jul-Dez, 2010.
} 
essential instrument of contract enforcement in a developed economy and therefore an important determinant of competitiveness (see next section). At the same time, the spanish system is costly, requires a high public expenditure $(0.35 \%$ of GDP in Spain, 2003, 0.5\% if we also include prisons) and employs an important number of public workers (57000) for whom an appropriate system of incentives and productivity is needed.139

Mora-Sanguinetti concludes the Spanish Judicial system has slowed both by fewer cases reaching final resolution in the court of initial hearing and that the pending docket of these same courts has increased 33\% since 2001. His thoughts, of course, echo the opinion of the civil court system of the general public in spain and in Texas. The court process is too expensive, takes too long, and is a stumbling block to economic growth. How does Mora-Sanguinetti's statement compare to a similar comment made by a legal scholar in the United States? According to Bill Henderson, Professor of Law and Val Nolan Faculty Fellow of the Maurer School of Law at the University of Indiana, and Rachel Zahorsky,

Law touches on virtually every aspect of our [the United States] social, political and economic lives. As the world becomes more interconnected and complex, new legislation, regulation and treaties bind us all together in ways that promote safety, cooperation and prosperity. Not surprisingly, over the last 25 years data shows legal services constitute a slightly larger proportion of the nation's GDP-now nearly 2 percentwith no hint of decline. ${ }^{140}$

\footnotetext{
${ }^{139}$ Ibid. 214.
}

${ }^{140}$ William D. Henderson and Rachel M. Zahorsky. "Paradigm Shift". American Bar Association Journal, July 2011. 41. From 2009-2014, Henderson served as the director of Indiana Law's Center on the Global Legal Profession. http://www.law.indiana.edu/about/people/bio.php?name=henderson-william-d\#profile-biography . 
The GDP in the United States in 2011 was 15.518 trillion

dollars, hence the amount spent on legal fees at $2 \%$ was $\$ 310.360$ billion dollars. Assuming that Mora-Sanguinetti's .35\% included all "legal services" as Henderson and Zahorsky loosely define it, it is obvious that although MoraSanguinetti feels Spain's public expenditures are "high" they are nowhere near (or can be interchanged in this case with "not nearly") as high as in the United States.

\section{The Timeliness of Jurisprudence of Water in Texas}

Texas jurisprudence of water issues is sadly so bifurcated and so confusing that most major cases take over a decade, or even longer, to be resolved. Two critical court cases took almost 20 years to come to any conclusion and both have left the water policy making community in Texas disappointed and still seeking answers.

\section{Day vs. the Edward's Aquifer Authority - A Groundwater Case}

Suffice it to say, most landowners and legal experts in Texas for many years considered groundwater underneath their land to be their property; a bill, sB332 passed easily by a large margin in both houses of the $82^{\text {nd }}$ Texas Legislature in 2011 and for once and for all clarified in law that groundwater in Texas is owned by the surface landowner. Most Texans have also felt that any taking of that groundwater by 
eminent domain or other regulatory action should be compensated. In the first sentence of the ruling in the case of The Edwards Aquifer Authority and the State of Texas $v$. Burrell Day and Joel McDaniel, Justice Nathan Hecht wrote,

We decide in this case whether land ownership includes an interest in groundwater in place that cannot be taken for public use without adequate compensation guaranteed by article 1 , section 17 (a) of the Texas Constitution. We hold that it does. ${ }^{141}$

The dispute in the case arose in 1996 when landowners Day and McDaniel requested a permit to draw 700 acre-feet of groundwater per year from the Edwards Aquifer, regulated by the then recently formed Edwards Aquifer Authority (EAA), and were granted only 14 acre-feet by the EAA. ${ }^{142}$ The issue eventually considered by the Texas supreme Court was not about the EAA's authority; the court decided EAA's authority was clear, the EAA acted properly. ${ }^{143}$ The landmark issue that the Texas Supreme Court considered was whether Day had a constitutionally protected interest in the groundwater

\footnotetext{
${ }^{141}$ The Edwards Aquifer Authority and the State of Texas, Petitioners, v. Burrell Day and Joel McDaniel Respondents In the Supreme Court of Texas No. 08-904, page 1.

142 Ibid. 7.

${ }^{143}$ Ibid 11.
} 
beneath his property; they concluded that Day's interest was constitutionally protected. ${ }^{144}$

The Day case made it clear that groundwater is owned by the surface landowner and that the ownership interest is constitutionally protected by the state of Texas. The next big question, which further litigation in the Day case will determine is this: How much groundwater regulation is too much? The preferred method of management of groundwater in Texas is by locally managed Groundwater Conservation Districts. ${ }^{145}$ Since the EAA is a unique form of groundwater conservation district, every groundwater conservation district will watch the Day case closely as it progresses through the court system to determine their limitations in allocating their constituents' privately owned groundwater, especially in light of a significant entrepreneurial effort of those whose business goal is to "harvest, transport, and sell" groundwater to many of Texas' thirsty cities. The Texas Supreme Court issued a long awaited opinion in the case Day and McDaniel v. Edwards Aquifer Authority on February 24, 2012.146 Private landowners, groundwater

\footnotetext{
${ }^{144}$ Ibid 8.
}

${ }^{145}$ As confirmed over the last decade several times by the Texas Legislature. However, not all of Texas has chosen to be covered by a groundwater conservation district.

${ }^{146}$ Edwards Aquifer Authority v. Day, S.W. 3d, 2012. 
conservation districts, cities, and many other stakeholders, including key trade associations, followed this case for years as it passed through the court system. The case scared many entities involved in the regulation of groundwater since the potential compensation award could prove unaffordable when applied to the thousands of permits and denied permits across the state. Many viewed the ruling as the ultimate determining factor in the affordability, possibly even the existence, of our current groundwater management systems. The unanimous decision of the Texas Supreme Court in this case consisted of two legally significant rulings. The first ruling was that landowners in Texas own the groundwater "in place" beneath their property, which clarified for once and all the ownership of groundwater in place by the surface landowner. (How one can absolutely prove the amount of groundwater in place is problematic since water is "fugitive" and moves around at will all the time.) The second ruling was that landowners may have a valid claim for just compensation from a government entity if the regulations and or regulatory ruling went too far in limiting groundwater withdrawals, which opened the door to further litigation about "how much groundwater regulation is too much." If the evidence proves the government entity went too far in their regulatory 
efforts, those efforts could be a "taking" of the landowners"

private property. Justice Nathan Hecht wrote in the opinion:

We decide in this case whether land ownership includes an interest in groundwater in place and cannot be taken for public use without adequate compensation guaranteed by Article 1, section 17 (a) of the Texas Constitution.147 We hold that it does. We affirm the judgment of the court of appeals ${ }^{148}$ and remand the case to the district court for further proceedings. . . We begin by considering whether, under the EAAA, the Authority erred in limiting Day's IRP [Initial Regular Permit] to 14 acre-feet of water and conclude that it did not. Next, we turn to whether Day has a constitutionally protected interest in the groundwater underneath his property and conclude that he does. We then consider whether the Authority's denial of an IRP in the amount Day requested constitutes a taking and conclude that the issue must be remanded to the trial court for further proceedings. ${ }^{149}$

The court concluded, based upon the evidence presented, that it could not determine, as a matter of law, if the EAA did or did not take Day's property. According to Hecht, "A full development of the record may demonstrate that EAAA [The Edwards Aquifer Authority Act] regulation is too restrictive of Day's groundwater rights and without justification in the overall regulatory scheme."150 The court sent the case back to

\footnotetext{
${ }^{147}$ Texas Constitution Article 1, 17 (a). "No person's property shall be taken, damaged, or destroyed for or applied to public use without adequate compensation being made ...."

${ }^{148}$ Edwards Aquifer Authority v. Day, 274 S.W. 3d 742 (Tex. App.-San Antonio 2008).

149 "Ruling" page 1 and page 8.

150 "Ruling" page 45.
} 
the trial court in Atascosa county (Jourdanton) for further consideration.

As clear as the court was about groundwater ownership in place, its ruling leaves the question of how much groundwater regulation is too much before the regulation becomes a taking open for further review. According to authors Tom Mason and Robin Melvin:

As a practical matter, Day means it may take a number of landowner lawsuits that assert takings claims against groundwater districts - each based on unique facts and circumstances - before enough case law is developed to provide clearer guidance on how much groundwater regulation is too much. ${ }^{151}$

The case arose from the plaintiffs' disagreement on the amount of groundwater they could pump from the Edwards Aquifer. The Plaintiffs asked the EAA for a permit to pump 700 acre-feet per year from a water well on their 381.4 acre ranch. Day timely applied for the permit before the deadline of December 30, 1996. In November 2000, the EAA denied the application for 700 acre-feet. Day appealed and the matter was sent to the State Office of Administrative Hearings. The administrative law judge concluded that Day should be granted a permit for 14 acre-feet per year. The key aspect of this case for all landowners in the Edwards Aquifer Authority's

151 Thomas G. Mason and Robin A. Melvin. "New Developments in Texas Water Law, Planning and Management.” Presented to the Austin Bar Association Real Estate Section Meeting, March 6, 2012. 
jurisdiction is what evidence is acceptable to prove

"historical use" of groundwater.

The facts supporting the plaintiffs' request were complicated. The water well in question had not been in service since 1983 when landowners removed the pump; it still flowed under artesian pressure into a channel that led to a tank or reservoir on their land. Day offered eyewitness testimony from the period at the administrative hearing but under cross-examination, one witness admitted a lack of knowledge of key facts concerning the amount of water pumped historically. The volume of water drawn from the well was not measured by a water meter; the amount of water historically produced could not be accurately determined. Under the existing exemption for domestic and livestock use, the plaintiffs could pump 25,000 gallons per day equating to 28 acre-feet per year without a permit. But Day's purpose for this water was for irrigating his pasture.

The lack of documentary evidence to support historical use was fatal to Day's argument; the witnesses he called were of no help, either. Hecht wrote, "Day, having offered no other evidence of beneficial use during the historic period, 
the Authority's decision to issue an IRP for 14 acre-feet must be affirmed."152

The court summed up the remaining issue in the case at the end of Section III of their ruling. Addressing the EAA's warning that if its groundwater regulation can result in a compensable taking, the consequences will be nothing short of disastrous, Justice Hecht wrote, "Groundwater rights are property rights subject to constitutional protection, whatever difficulties may lie in determining adequate compensation for a taking."153

According to the Edwards Aquifer Authority Act, "The Legislature intends that just compensation be paid if implementation of this article causes a taking of private property or the impairment of a contract in contravention of the Texas or federal constitution."154 Justice Hecht wrote, "The requirement of compensation may make the regulatory scheme more expensive, but it does not affect the regulations themselves or their goals for groundwater production."155 Later he continued, "We cannot know, of course, the extent to which the Authority's fears will yet materialize, but the

\footnotetext{
152 "Ruling" page 11.

${ }^{153}$ Ibid. 28.

${ }^{154}$ Edwards Aquifer Authority Act, section 1.07.

155 "Ruling" 45.
} 
burden of the Takings clause on government is no reason to excuse its applicability."156

The Day case that began in 1996 took 16 years to the partial ruling by the Texas Supreme Court. Still, all water policy makers in Texas were pleased that after so long a time finally the original court had somewhat clearer directions. Sadly for us all, the family of Day and McDaniel decided to forego further court activity and settled for a meager $\$ 950,000$ in June 2012,157 an amount that surely did not cover their legal fees over 16 years.

\section{Bragg v. the Edwards Aquifer Authority - Another Groundwater Case}

The case known in Texas water law as Bragg, began with the filing of a lawsuit in 2006; actually, the dispute had begun in 1996 in a very similar way to the Day case. The irrigation wells for these farms required permits from the Edwards Aquifer Authority (EAA). When the Braggs requested more groundwater than the EAA granted, long years of litigation resulted in decisions generally in favor of the EAA. However, the Braggs persisted in the face of these unfavorable rulings and filed another lawsuit under a

\footnotetext{
${ }^{156}$ Ibid. 46-47.
}

${ }^{157}$ Announcement by the Edwards Aquifer Authority made public June 9, 2012. 
"takings"158 claim against the EAA after an appeals court

ruling in a similar and more famous case, Day and McDaniel $v$. the Edwards Aquifer Authority, 159 brought up the possibility that the EAA owed landowners just compensation for their regulatory actions. The Braggs' new lawsuit sought just compensation from the EAA for the amount of groundwater they were denied.

Finally on February 22, 2016, some 10 to 16 years later, dependent upon one's perspective, the courts made a final ruling in the case. According to the San Antonio Express News on February 22, 2016,

Glenn Bragg, a retired Texas A\&M University extension agent, used his retirement savings to first buy the 60acre property they call "Home Place." He planted more than 1,800 trees on the land.

In 1983, the couple bought another 40-acre orchard near D'Hanis and planted 1,500 trees. Both orchards relied on Edwards Aquifer wells drilled on the property.

After the EAA's regulations went into effect in 1996, the Braggs applied for two pumping permits based on historic use for those orchards. The EAA issued a permit for half the volume they asked for on one orchard and denied the permit other entirely. The Braggs then sued the authority in 2006 .

${ }^{158}$ Greg Ellis. "Regulatory Takings and Texas Groundwater" an article pending publication found at http://www.schreiner.edu/water/pdf/RegulatoryTakings\&TexasGroundwaterLaw.pdf; Also Black's Law Dictionary defines taking as "There is a 'taking' of property when government action directly interferes with or substantially disturbs the owner's use and enjoyment of the property. Grothers v. U.S., C.A.Or., 594 F.2d 740,741. To constitute a "taking, within constitutional limitation, it is not essential that there be physical seizure or appropriation, and any actual or material interference with private property rights constitutes a taking."

${ }^{159}$ Cause No. 08-0904 in the Texas Supreme Court. 
The government agency in charge of the Edwards Aquifer must pay two pecan farmers upwards of $\$ 2.5$ million for limiting their groundwater pumping, a jury decided Monday.

The verdict came as welcome news to Glenn and JoLynn Bragg. The couple has been in litigation with the Edwards Aquifer Authority for 10 years after suing the EAA for denying one of their groundwater applications and cutting the other in half. "We' re pleased to have it over," JoLynn Bragg said. "We can live with this." Including interest, the total owed to the Braggs is expected to be more than \$4 million, their attorney Paul Terrill said. "These two had something very valuable taken from them," Terrill said. "Today, they finally, finally after 10 years, got some measure of justice.160

The dispute had begun in 1996 when the Braggs filed their first lawsuit against the EAA, therefore the entire time of litigation took 20 years to reach a full conclusion as was also reported in the San Antonio Express News on May 12, 2015,

The Braggs had earlier sued the EAA in 1996, alleging its permitting process denied them water they needed for their orchards. That lawsuit reached the state supreme Court, which upheld the EAA's ability to regulate groundwater. ${ }^{161}$

Another delay in justice in the Texas jurisprudence and regulatory system is in the slow and at times duplicitous water project and water rights permitting system.

\footnotetext{
${ }^{160}$ Brenda Gibbons. "Edwards Aquifer Authority must shell out to pecan farmers". San Antonio Express News, February 22, 2016

${ }^{161}$ Scott Huddleston. "Key ruling stands in aquifer lawsuit”. San Antonio Express News, May 12, 2015
} 


\title{
Permit Process Timeliness in Texas Defeats Justice
}

\author{
A subject of one of the focus groups for this study was \\ the lack of a timely jurisprudence system in Texas from the \\ viewpoint of the private sector. On February 16, 2016 \\ Timothy L. Brown, past General Counsel for the Texas \\ Commission on Environmental Quality,162 and Jason Hill, water \\ law attorney named as one of Texas Super Lawyers, ${ }^{163}$ met with \\ me in a focus group format; the goal was to discuss the \\ permitting process in Texas only. ${ }^{164}$ Both shared their \\ frustrations with a cumbersome process both in groundwater \\ and surface water permitting. \\ Hill opined that once past the initial hearings at the \\ GCD level, if your client is not satisfied with the results, \\ the next step in the process is to go to the State Office of \\ Administrative Hearings (SOAH). If the client's result from \\ this hearing is not satisfactory, then the choice is a
}

\footnotetext{
162 Tim Brown has practiced water law in Texas for over 40 years. His early career was with the Texas Water Rights Commission as one of the first regulatory agency officers for promulgation of the 1967 Texas Water Rights Adjudication Act. As the Texas Water Rights Commission morphed into the Texas Commission on Environmental Quality, Tim became General Counsel for the agency. He also served as a Texas Assistant Attorney General, as Chief of the Environmental Protection Division of the Texas Attorney General's Office. He has entered private practice with Sledge Law in Austin, Texas.

${ }^{163}$ Jason T. Hill is a water law attorney in Austin, Texas. He has earned the ranking of Super Lawyer in Texas and Best Lawyers. He has extensive experience in representing clients in contested case hearings before the State Office of Administrative Hearings, the Railroad Commission of Texas, and many other political subdivisions.

${ }^{164}$ I say only in Texas since many water rights permits must not only be processed by Texas regulatory agencies but also by the US Army Corps of Engineers and the EPA among other federal agencies. The focus group was held at the Austin Club on February 16, 2016.
} 
lawsuit in district court. If the client decides to appeal an unfavorable ruling in district court, then the next step is the appeals court in Austin. All water permitting cases are supposed to be heard in Austin to provide some continuity and predictability in the administration of the law. However, the last few years the concept of "judicial equalization" has entered Texas law. Many times a permit case that should have been heard by a panel of appeals judges in Austin who have experience in the matter at hand was set in El Paso, Amarillo, or other far away appeals courts who simply do not see water permit cases often enough to gain expertise and present a consistent and predictable ruling. Brown discussed the surface water permitting process and expressed his frustration with the TCEQ legal staff. Even the simplest permits, such as allowing two clients with senior appropriative rights to use surface water to trade a portion of their water right to the other under an agreed contract inside the exact same region has taken up to three years to process. Brown observed that the TCEQ takes permits on a "first come, first serve" basis. Woe be unto the proposed permit, even if it is an obviously simple approval, if there is a more complicated case in front of it. The staff of the TCEQ will not triage the permits. Many of the simple uncontested permits could be processed all but immediately, 
but due to the process now, even the uncontested permits take inordinate periods of time to work through the system. Water projects and use are categorized as a "time is of the essence" type activity. In Brown's example, the probable reason the permit holders decided to trade their volume allowances were to support some change in the crops they were planning to grow, the new crop needing more water. The decision was made for economic reasons, but with the rapidly changing market for agricultural products, a several years long permitting process could cause the permit traders to miss the market. The permitting process must be timely or justice is denied.

There is another level of expense and delay when a permit is proposed that not only has to gain state approval but federal agency approval as well. From my service on the Texas Water Conservation Association (TWCA) Surface Water WARP/WAM and State Permitting subcommittee, I had the opportunity to discuss the nature of the state/federal permitting process with the stakeholders who daily deal with actual permits for water projects. The committee of 70 plus members met at the Lower Colorado River Authority board room in Austin, Texas on March 31, 2016. Denis W. Qualis, P.E., D.WRE, Senior Program Manager of the Dallas Water Utilities, City of Dallas, Texas, spoke at the podium and then later to 


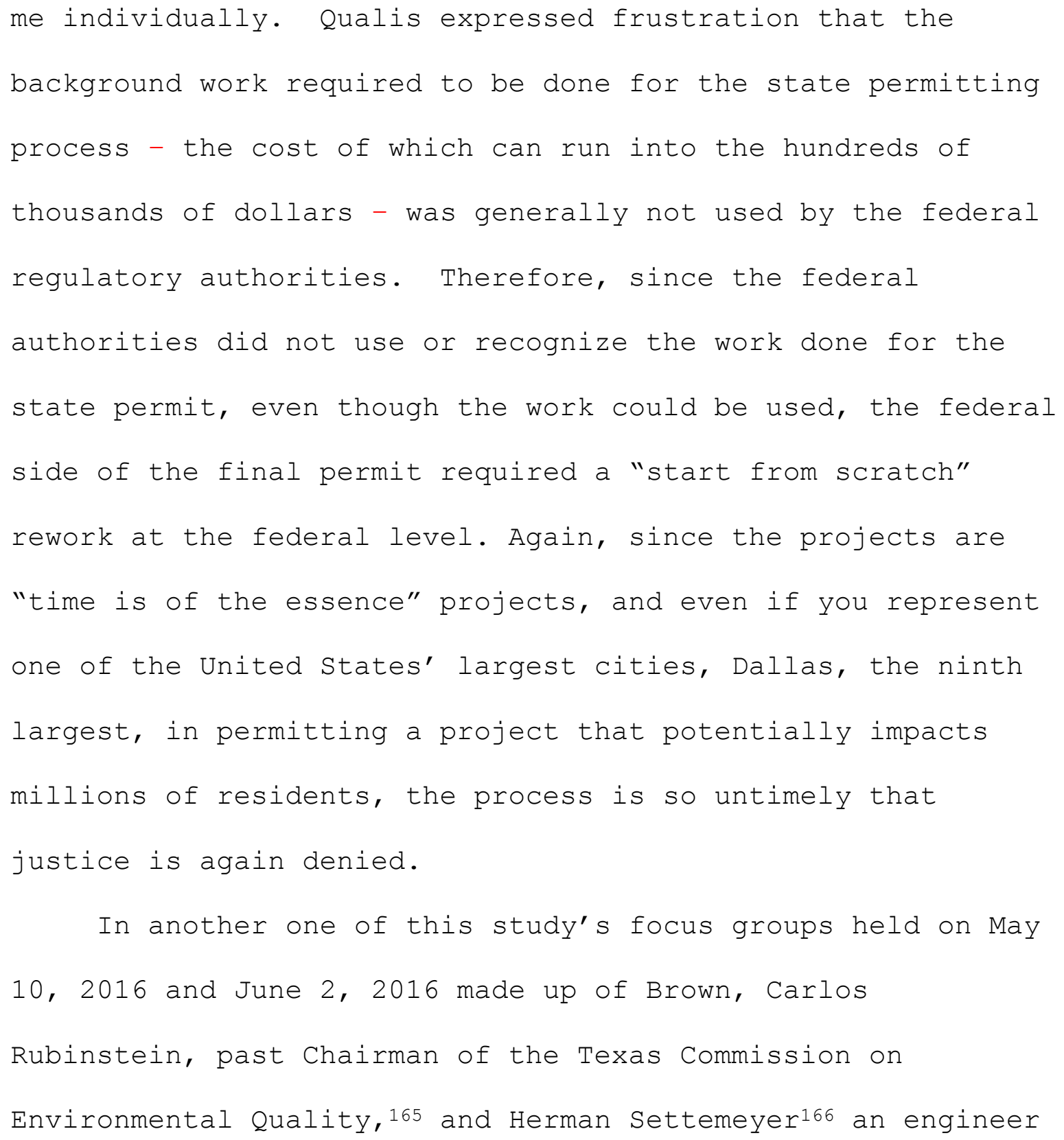

\footnotetext{
${ }^{165}$ Carlos Rubinstein is a licensed civil engineer, past Rio Grande Watermaster for the State of Texas, past Commissioner of the Texas Commission on Environmental Quality, past Chairman of the Texas Water Development Board and a leading expert in water law and permitting both at the state and federal levels. He is a partner in RSAH20 a consulting firm in Austin, Texas.

${ }^{166}$ Herman Settemeyer is a licensed professional engineer with 40 years of experience in water regulation in Texas working for the Texas Commission on Environmental Quality. He was the TCEQ representative in interstate rive compact administration, international treaty compliance officer, was involved in the adjudication of surface water rights in Texas under the 1967 Water Rights Adjudication Act, and permitted and enforced water rights and management policies in Texas. He is one of the foremost experts on Texas surface water permitting. He is a partner in RSAH20 a consulting firm in Austin, Texas.
} 
with over 40 years of experience in water permitting at both the federal and state levels, a discussion was held about the lack of timeliness in the surface water permitting process in Texas from the regulatory authority's viewpoint. This lack of timeliness is a contributing cause to the lack of interbasin water transfers from wetter areas of Texas to drier areas. All three experts had actively processed surface water permits at the state level, Rubinstein at the very highest level in his role as chairman. The consensus opinion was that the agency was short of staff, especially seasoned staff, and that the normal process of permitting could be improved, if only by triaging the permit applications and assigning the more basic undisputed permits to a separate group of staff so as to avoid a large disputed permit having a first come, first serve position that slowed the entire department's work to a crawl. We discussed the staff's legitimate concern about politics at the commissioner's level since commissioners have limited terms and are political appointees.

There is little dispute that the water permitting process at both the state and federal level in Texas is flawed and almost unworkable economically. What is the 
financial consequence? The answer is centered on what the true market value of water is. Yet, valuing water, the key to assessing damages in court cases involving water as the issue, is a challenge.

From extensive inquiry the next section of this study offers a model for water valuation using Texas as an example but the model can be adapted easily with unique inputs and characteristics of any region of the world. The model is an effective methodology for all water valuation.

\section{The Challenge of Fair Market Valuation of Water}

Many Texans, when asked, profess confusion about how to determine their water rights, what government entities regulate water, and of utmost importance, the market value of the water they own. Everyone feels as if their water right has value, but few have experienced the sale of that water. There is no Multiple Listing Service available as in residential property sales to instantly find true and reliable comparable sales in water transactions. There is no Blue Book for guidelines as to value as exists for automobiles. To begin the process of sale of a water right, first a buyer, seller, or lender must gain a fundamental understanding of who owns the water, what regulations apply, if any, to allow the transfer of that water to the purchaser or lessee, and what process is required to close a sale or 
lease of the water right. A thorough investigation must be undertaken to determine the credible and defendable fair market value of water. This is especially challenging no matter the methodology used. The commonly heard saying that "water is the next oil" is fundamentally flawed. Water is an all but real time renewable resource and is to be conserved and ideally allocated fairly; oil is a resource that is only renewable over millennia and is to be mined by the highest bidder. Certainly water has real value; it has been said "water renders the land its value,"167 nothing could be more true especially in most farm and ranch real estate transactions. To begin to discover an answer to credible and defendable valuation of water and water rights it is important to first understand some basics about water, ownership, and regulations.

\section{A Brief Texas Water Law Primer}

Water rights in Texas vary between water flowing on the surface and water underground, vary from regulatory agency to regulatory agency, vary from place to place, and vary from time to time. A good example of the "conventional wisdom" that water rights in Texas are convoluted and at times in the

\footnotetext{
${ }^{167}$ Letter from George W. Brackenridge to "Brother Tom" [his brother Thomas] recommending Thomas' land in Junction, Texas should only be sold if it included the section with water on it, "as water render the land its value." November 19, 1879. Austin History Center, Robert Thomas Brackenridge Papers, La PrelleBrackenridge Papers.
} 
recent past, incomprehensible, is found in a ruling in 1955

made by Federal Judge James V. Allred, a former attorney

general and governor of Texas. Allred wrote,

For years it has been a matter of common knowledge that the Texas water laws and decisions are in hopeless

confusion; that even if they are clear as some attorneys profess to believe them, their application and administration would be difficult ... . ${ }^{168}$

When a well-known jurist such as Judge Allred expresses confusion and frustration with our water laws and decisions, in a published decision no less, it is understandable why the general public may share his feelings. Still today, few Texans understand the wider view of the legal, social, and economic consequences of our water rights system. Water rights are the most fundamental "stick" in the "bundle of sticks"169 that determine all the "property rights" and much of the market value of any real property in Texas. Real estate adjacent to surface water, with surface water irrigation diversion rights, with groundwater irrigation rights, and with large amounts of fresh potable groundwater simply sells at higher prices, and at times, at many multiples higher than land without adequate water.

\footnotetext{
${ }^{168}$ Martinez v. Maverick County Water Control and Improvement District No. 1, 5th Cir.,1955, 219 F. 2d 666,670 .

169 Judon Fambrough of the Texas Real Estate Center uses the "bundle of sticks" phrase in his writings and teachings - very appropriately. "Real property" is defined as land and all the things that are attached to it.
} 
Why else is it important to know about water rights in Texas? In addition to the significant impact water rights have on the value of real property, statutory obligations have created a need to understand water rights because all known defects in real property must be disclosed to any potential purchaser during the time the purchasers are making their decision to buy. This duty to disclose any defect known, including a known defect in a water right, is shared by sellers, lessors, and their real estate agents. Buyers and lessees must know about the water rights to a property they are considering but first must have to know the questions to ask about water rights in general. The duty to disclose all known defects has become a part of our everyday real estate transactions in Texas and in most parts of the United States. As water becomes scarcer throughout our state due to population growth and our inevitably recurring droughts, the need for sellers, buyers, and real estate agents to fully understand the water situation associated with any property for sale has become critical.

Today, assessing the water characteristics of any particular property presents unique challenges to buyers, sellers, lessors, lessees, real estate agents, accountants, attorneys, and estate planners. The water scarcity predicted in our future requires potential buyers to consider a variety 
of heretofore less often considered assessment criteria. Likewise, the potential of future water scarcity requires sellers and their real estate agents to exercise extreme caution and prudence in their fiduciary duties to their clients and their duties to the public as a whole regarding the water rights situation of any property being offered for sale or one being considered for purchase.

To further complicate a sometimes confusing and seemingly contradictory myriad of state water regulations, Texans must keep one other very important consideration in mind - several United States government agencies may have supra-legal170 authority over Texas water policy either directly or indirectly. Agencies such as the Environmental Protection Agency and the United States Fish and Wildlife Service promulgate rules that can significantly affect water rights, the congress passes laws which affect water rights, and the federal courts issue rulings which historically have drastically modified water policies nationally and in Texas. Local, state, and federal regulations can and do impact any calculation of the fair market value of a water right. Most Texans' understanding of their water right goes only as far as their ability to read the monthly water bill; as long

${ }^{170}$ Superior authority. "Supra" means "above" in Latin. 


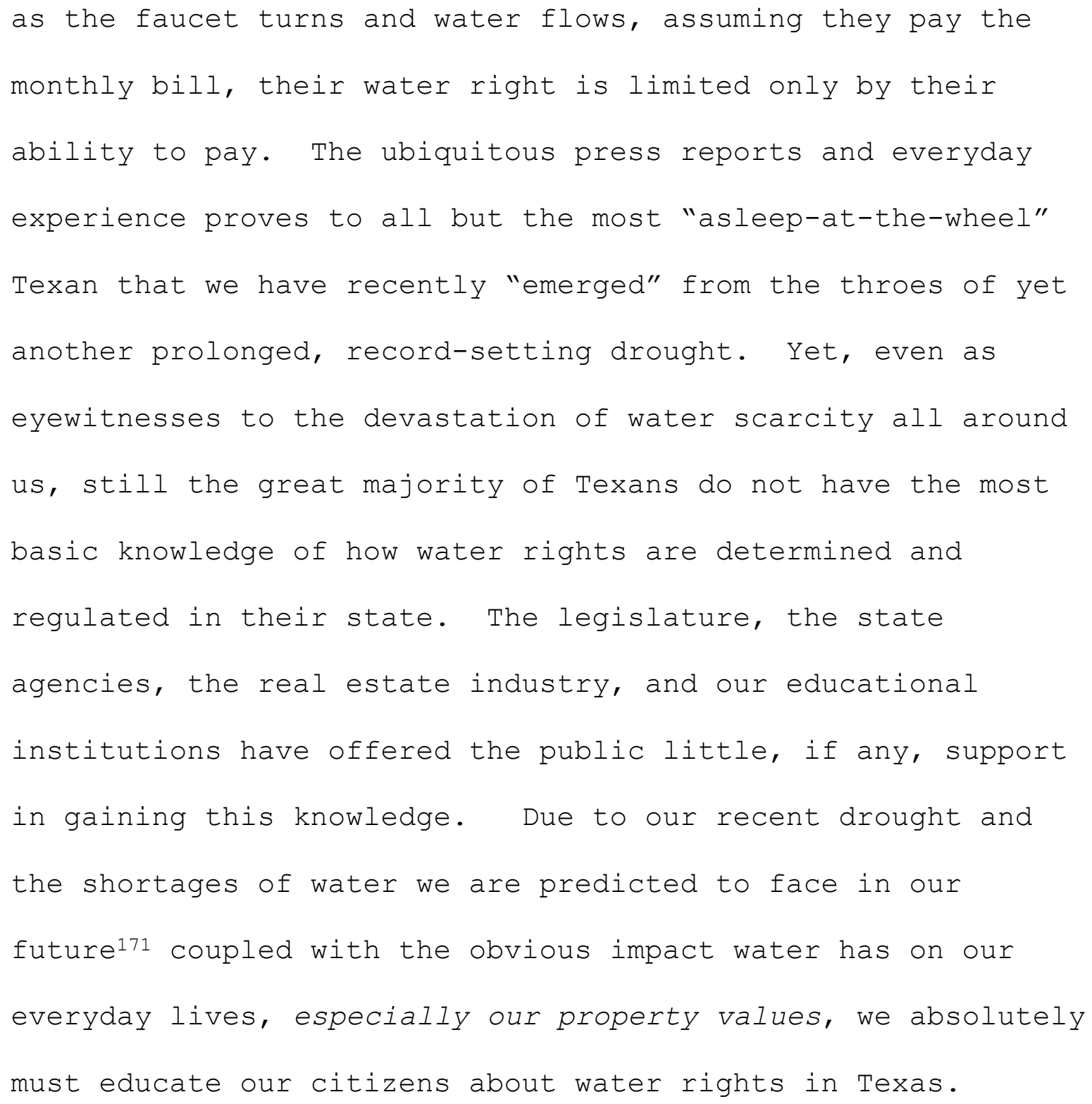

\footnotetext{
171 The Texas Water Development Board's (TWDB) State Water Plan for 2012 asked, "Do we have enough water for the future?" Their startling and unequivocal answer was: "We do not have enough existing water supplies today to meet the demand for water during times of drought. In the event of severe drought conditions, the state would face an immediate need for additional water supplies of 3.6 million acre-feet per year with 86 percent of that need in irrigation and about 9 percent associated directly with municipal water users. Total needs are projected to increase by 130 percent between 2010 and 2060 to 8.3 million acre-feet per year. In 2060, irrigation represents 45 percent of the total and municipal users account for 41 percent of needs."
} 


\title{
A Detailed Texas Water Rights Overview
}

\author{
Determining a water right in Texas depends on which of \\ three geological containers ${ }^{172}$ holds the water. The first \\ container is surface water or water that flows on the surface \\ of the ground in a watercourse. 173 The State of Texas owns the \\ water in a watercourse, held in trust for the citizens of the \\ state. The Texas Commission on Environmental Quality (TCEQ) \\ regulates use of surface water in Texas by a system of water \\ rights. ${ }^{174}$ The TCEQ, through its authority in allocating water \\ rights, essentially oversees the 17 statewide river \\ authorities and 4 Watermasters ${ }^{175}$ as well.
}

\begin{abstract}
${ }^{172}$ The term "geological container" to describe water types in Texas can generally be traced to the fine work of Dr. Ron Kaiser of Texas A \& M University.

173 "Watercourse" in Texas law is not found in the statutes but in the 1925 case Heofs v. Short, 273 S.W. 785 (Tex. 1925). "When it is said that a stream in order to be a natural water course to which water rights attach must have bed, banks, a current of water, and a permanent source of water supply, we have only described in detail such physiographic and meteorological characteristics as make the use of the stream for irrigation practicable. When it is once shown that the waters of a stream are so confined and persistent in their course, and flow with such frequency and volume that it is both practicable and valuable to irrigate therefrom, it is a stream to which such water rights attach."
\end{abstract}

With reference to the phrase 'definite and permanent source of supply of water", frequently used by the courts as describing a necessary requisite of an irrigable stream, all that is meant is that there must be sufficient water carried by the stream at such intervals as may make it practicable to irrigate from or use the stream. ... The authorities frequently say that a natural watercourse must have a permanent source of water supply. This however merely means that the stream must be such that similar conditions will produce a flow of water, and that these conditions recur with some degree of regularity, so that they establish and maintain a running stream for considerable periods of time. Farnham on Waters, Vol. 2, § 457; Ruling Case Law, Vol. 27, pp. 1065, 1066; Kinney on Irrigation, Vol. 1, §306.”

${ }^{174}$ There are 17 river authorities in Texas and a number of other special districts authorized by the legislature.

175 On April 21, 2014 TCEQ Chairman Bryan W. Shaw signed an order 2013-0174-WR that "partially granted" the Petition for the appointment of a watermaster in the Brazos River Basin. This will bring the number of watermasters to 4 the others being the Concho River Watermaster, the South Texas Watermaster, and the Rio Grande Watermaster. The Order states: "NOW, THEREFORE, BE IT ORDERED BY THE TEXAS COMMISSION ON ENVIRONMENTAL QUALITY THAT: 1. The Petition for the appointment of a watermaster in the Brazos River Basin is partially granted." (The Petition was "partially granted" because only 
The second geological container is known as diffused

surface water or rainwater that runs off your roof or over the surface of your land without flowing in a stream or channel. The water in this container is owned by the landowner. The TCEQ ostensibly oversees this geological container, but there is no record of any hearings or rulings in the archives.

The third container is groundwater or water held underground in aquifers and pools. Ownership of groundwater in Texas was debated for many decades, but in the fall of 2011 the debate about ownership of groundwater ended for all practical purposes: The Texas Legislature passed a bill (generally known as senate Bill 332 by Fraser) which states "The legislature recognizes that a landowner owns the groundwater below the surface of the landowner's land as real property." The bill was signed into law by Governor Perry, effective September 1, 2011. Groundwater is regulated by 100 Groundwater Conservation Districts (GCDs) with 100 different sets of rules and regulations. Not all of Texas is under the jurisdiction of a GCD either. Certain special groundwater districts have been created by the legislature, perhaps the

the Lower Brazos River Basin was included.) Section 2 of the Order states: "The ED shall appointment a watermaster with jurisdiction over the Lower Brazon River Basin, which will consist of all water rights holders in the Brazos River Basin including Possum Kingdom Lake and below that Lake in the Brazos River Basin.” 
best known is the Edwards Aquifer Authority, which regulates

the groundwater in the aquifer of the same name. Most

citizens in these jurisdictions are unaware of these

regulatory agencies.

According to water law expert, Edmond J. McCarthy, Jr.,

a fourth container to be considered is "developed" water:

Developed water is generally considered to be new water because it has been artificially introduced into the watercourse, i.e., it is water that would not be part of the normal flow of the watercourse but for the activities of the developer. Developed water can include drainage, return water, groundwater delivered to a watercourse, and surface water that is returned to a watercourse other than the originating watercourse or river basin. In the context of surface water owned by the state, so long as the owner of the developed water retains physical control over it, he has the right to its continued beneficial use for the purpose(s) authorized by his water right, e.g., permit, certificate of adjudication, or certified filing. Like diffused water, once physical control of the developed water is either lost or abandoned and it is allowed to flow into a watercourse and again become part of the ordinary flow, it loses its character as developed water and reverts to state owned surface water. Additionally, once the water right holder has beneficially used the surface water, it cannot be claimed as developed water if by the terms and conditions of the authorization it must be returned to a watercourse. ${ }^{176}$

Mr. McCarthy's developed water category recognizes the economic value of water projects and inserts another element of justice into the foundations of Texas water law. Once any

${ }^{176}$ Edmond J. McCarthy, Jr. “Mixing Oil and Gas with Texas Water Law.” Texas Tech Law Review, 2007. Vol. 44. 889. 
entity has followed the permitting process to earn a valid permit, once the entity has invested in the infrastructure of the water project, the water generated or "developed" from this project and investment which has varying degrees of financial risk, should be categorized and treated differently from the natural geological containers.

\section{Surface Water Regulators and Regulations}

The "buck-stops-here" surface water regulator in Texas is the TCEQ. Generally, a permit is required from TCEQ in order to use surface water in Texas. According to the TCEQ, ". . anyone who wants to use surface water in Texas must first get permission from the state unless they are using the water for one of several exempt uses. These exempt uses allow anyone to use surface water without getting permission."177 Domestic and livestock use, wildlife management use, and emergency use by fire departments and other similar public services comprise the bulk of these exemptions. Surface water rights in Texas are fully allocated and have been for years. It is likely that the surface water found any place west of IH 35 in Texas can be said to be over allocated, at least on paper, due to recurring droughts. The decades long implementation of the Water Rights

\footnotetext{
177 http://www.tceq.state.tx.us/publications/gi/gi-228.html/at_download/file - "Rights to Surface Water in Texas” Texas Commission on Environmental Quality, GI-228 (Rev. 3/09).
} 
Adjudication Act of 1967 clarified individual surface water rights for agricultural (generally irrigation), industrial, municipal, and other specific uses. The 17 river authorities promulgate regulations regarding surface water also under the broad purview of the TCEQ.

An example of the public's lack of knowledge about surface water regulations is found in the all but standard question asked about lake water use. Most often this question comes from Lake Travis property owners or potential purchasers of land there: "May I pump water from the lake to my home since I am adjacent to the water?" The answer is "no, you must obtain a permit from the Lower Colorado River Authority to do so." Many times upon hearing that answer, the questioner moves to a rather lengthy uniformed and incorrectly reasoned discussion of why he or she has "riparian" rights that overrule the LCRA's regulations, that they are going to take the water anyway, and they cannot wait to see the LCRA in court. Usually the questioner completes their comments with a rave about how the state needs to stay out of their business. The potential severity of the fines for violation of water use on a lake emphasizes the TCEQ's authority over the use of surface water or the river authorities' jurisdiction within their boundaries. There is another level of water regulation that even fewer Texans 
understand - the jurisdiction and duties of our 4 state Watermasters.

Texas water rights system and management is rooted in its Spanish heritage developed over the past 300 years. ${ }^{178}$ The role of the watermaster is one of the oldest regulatory and management of water in Texas. The first mayordomo ${ }^{179}$ in what would become later the state of Texas was appointed by the King of Spain in 1732 in Villa San Fernando, the predecessor village to modern San Antonio. The work of the mayordomo in Spanish Colonial Texas was very similar to the work of our modern watermasters. Today, according to the TCEQ，

Watermasters divide the water in their areas based on the adjudicated water rights, regulate as necessary the controlling works of reservoirs and diversion works, and monitor stream flows, reservoir levels, and water use. Watermaster programs ensure compliance with water rights by monitoring stream flows, reservoir levels, and water use. Watermasters also coordinate diversions and regulate reservoirs as needed to prevent the wasting of water or its being used in quantities beyond a user's right. Before diverting, a water right holder must notify the watermaster of the intent to divert at a specific time and the specific amount of water to be diverted. If the water is available and the water right holder will not exceed its annual authorized appropriation of water, the watermaster then authorizes the diversion and records this against the right. The watermaster programs include staff "deputies" who perform regular field inspections

${ }^{178}$ Charles Porter. Spanish Water/Anglo Water. 64. (Texas A \& M University Press, 2009); Charles Porter. Sharing the Common Pool: Water Rights in the Everyday Lives of Texans. 95-104. (Texas A \& M University Press, 2014).

${ }^{179}$ Generally known as "ditch boss" or in modern usage, a watermaster; Porter Spanish, 64. 
of authorized diversions to insure compliance with the water right. ${ }^{180}$

Decisions made by the four Texas watermasters can open the door for misunderstanding and at times, litigation. For example, in the Concho River Watermaster jurisdiction, those owning valid rights to divert water from the river have not been able to take their full appropriation of water for many years. Here is an example of the problems that can occur when the watermaster's regulations and practices are not disclosed to a potential purchaser of land. It is normal and quite acceptable for sellers of real property and their real estate agents to advertise the positive features of the property being offered for sale. Without doubt, a prior appropriative right, especially if the right is a senior diversion right, to take water from the Concho for irrigation purposes is a valuable feature of any property for sale. Yet, caution must be taken to fully and accurately disclose the details about the actual process and true volume of water the watermaster allowed to be taken.

Assume the seller has a senior appropriative right to divert 30 acre feet ${ }^{181}$ annually from the Concho, but the

\footnotetext{
${ }^{180} \mathrm{http}: / / w w w . t c e q . s t a t e . t x . u s /$ permitting/water_rights/wmaster/wmaster.html/\#about

${ }^{181}$ An acre foot of water equal 325,851 gallons.
} 
watermaster has only allowed diversions equaling to 10 acre feet annually in the past few years. The seller and real estate agents must modify their representations to inform the potential buyer that although the senior water right allows diversion of up to 30 acre feet a year, the amount diverted must not exceed 10 acre feet for the precise number of years. If not, especially since appropriative water rights are very valuable, the buyer may have claim for misrepresentation against the seller and real estate agent. This simple example is just one of many, and if surface water continues to grow scarcer hence more valuable, surely more opportunities for misunderstandings will occur. Groundwater regulations can be even more complicated across our state and just as unrealized by the general public.

\section{Groundwater Regulators and Regulations}

Groundwater Conservation Districts (GCDs) were first authorized by an act of the 1949 Texas Legislature; the first district formed in 1951. There are now 100 GCDs in Texas covering about $3 / 4$ ths of the state. 182 These districts are formed by local election but can be formed by the TCEQ or by direct actions of the legislature. Each district has its own set of rules and regulations, its own definition of terms

\footnotetext{
${ }^{182}$ The newest GCD is the Reeves County Groundwater Conservation District as of November 3, 2015.
} 


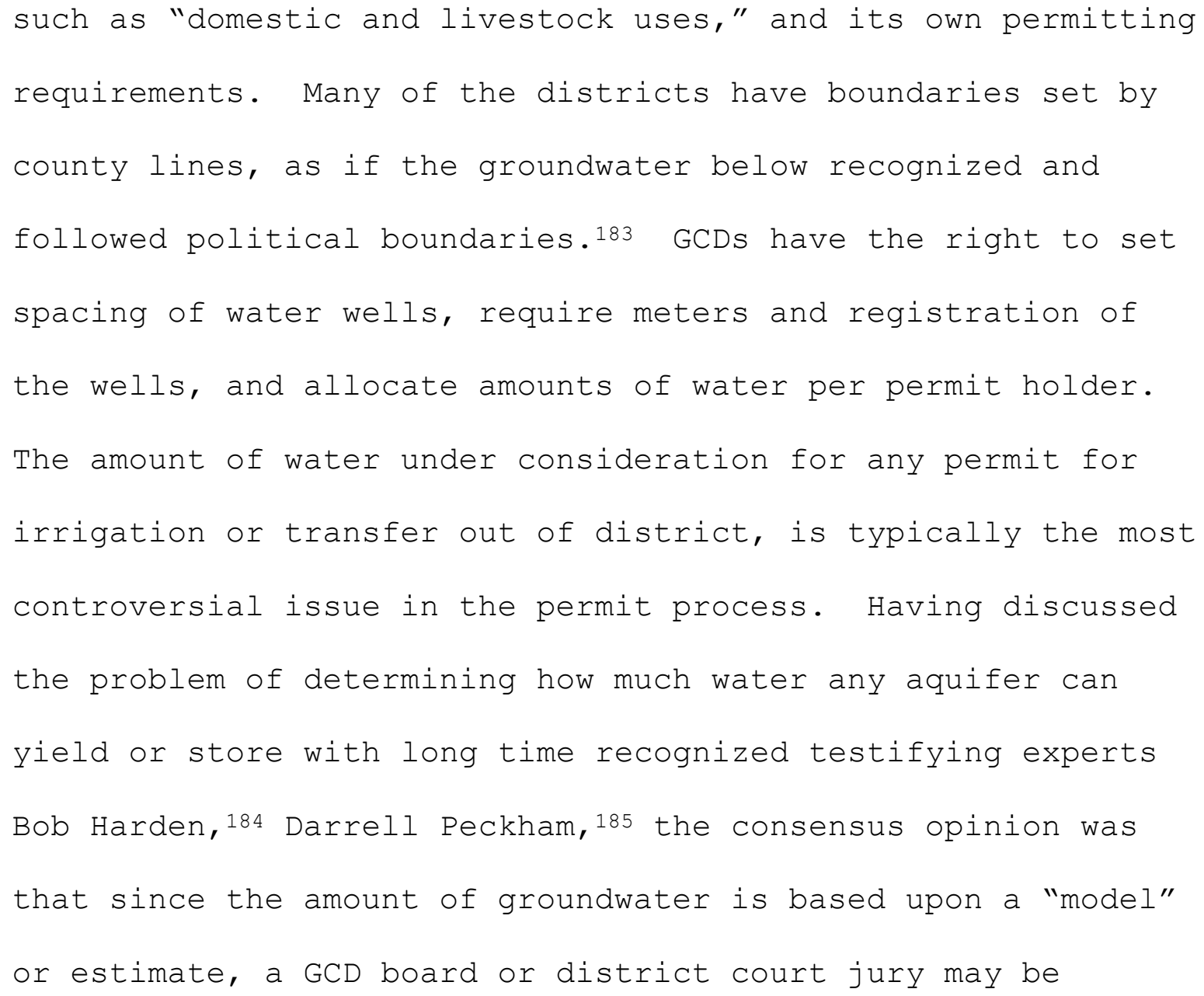

${ }^{183}$ Charles Porter. "Financing Groundwater Conservation Districts in Texas: Results of a Preliminary Study." Texas Water Journal 4, no. 1 (2013): 57-59.

${ }^{184}$ Bob Harden is Vice President of R.W. Harden \& Associates, Inc. Over the course of his career Bob has been involved in the discovery, acquisition, permitting, and development of new groundwater supplies for municipalities, water supply corporations, industry, and private landowners. Bob has a Master's Degree in Civil Engineering and is a professional engineer in Texas, Mississippi, and Indiana.

${ }^{185}$ Darrell Peckham, hydrogeologist, was formerly employed by the Texas Water Development Board (TWDB)/Texas Water Commission (TWC)/Texas Department of Water Resources (TDWR) with 15 years experience conducting ground-water studies in various aquifers across the state of Texas,including groundwater resources evaluations, ground-water protection recommendations, regional water management/conservation plans and recharge studies. Peckham has extensive background in computer modeling used to generate ground-water availability projection studies such as the Texas Water Plan. He designed, developed, implemented and supervised state-wide "Textural GIS" for the automation of determining the recommended depth of protection of useable-quality ground water in oil and gas wells. He is a member and leader of the Texas Water Information Network which included coauthoring the current process implemented by the Texas Department of Licensing and Registration which allows water well drillers to submit well reports via internet. He served on the State of Texas Governor's Division of Emergency Management Drought Monitoring and Response Committee's, Drought Monitoring Subcommittee chair. 
confronted with several qualified hydrological engineers sworn testimony that offers vastly different opinions on the amount of water available. Juries especially more often than not are confused about water modeling. Peckham mentioned that one of the most perplexing problems is the affect pressurization or depressurization of an aquifer has on its recharge and storage capacity. ${ }^{186}$

From the discussion with Harden and Peckham, another focus group was called and made up of attorney Tim Brown and arguably the most influential state of Texas regulatory agency water scientist, Robert Mace, Ph.D. ${ }^{187}$ The focus group was held on May 25, 2016. The goal of this focus group was to better understand a challenging element contributing to the lack of timeliness in groundwater permitting, the actual amount of groundwater available in any aquifer. Dr. Mace was asked particularly to discuss the effect of lowering of the artesian pressure in aquifers and how it can drastically impact the sustainable groundwater available for permit. He was asked to also discuss the complexities of this area of

\footnotetext{
${ }^{186}$ Both Bob and Darrell commented on the debate about water available complicated by the pressurization characteristics of individual aquifers.

${ }^{187}$ Dr. Robert E. Mace is the Deputy Executive Administrator of the Water Science and Conservation section of the Texas Water Development Board (TWDB). Dr. Mace leads a department of 70 scientists, engineers, and specialists dedicated to better understanding groundwater and surface water sources in Texas. He has been at the TWDB since 1999. Prior to working at the TWDB, Dr. Mace worked 9 years at the Bureau of Economic Geology at the University of Texas at Austin.
} 
water science. Dr. Mace's role as Deputy Executive Administrator of the Water Science and Conservation section of the Texas Water Development Board requires him to supervise 70 scientists and water experts in supporting water development in Texas. He is one of the most renowned national experts on groundwater. Dr. Mace said the artesian pressure in any aquifer has a direct relationship to the amount of water available for permitting. The effect of depressurization by new water wells varies from aquifer to aquifer across the state and is a scientific point of sometimes heated debate, rarely with any consensus among experts. All agree that the pressure inside an aquifer can change, sometimes fatally to the life of the aquifer, of the drainage of new water wells. The pressurization characteristics of all aquifers in Texas is a good place to try to hone in on streamlining the permitting process to avoid protracted debate in hearings.

The general public in Texas, unless they are very savvy or have discovered from their water well drilling contractor they had to apply for an irrigation permit from the GCD, has little or no knowledge that GCDs exist, even when they are in the jurisdiction of the few GCDs that have ad valorem 


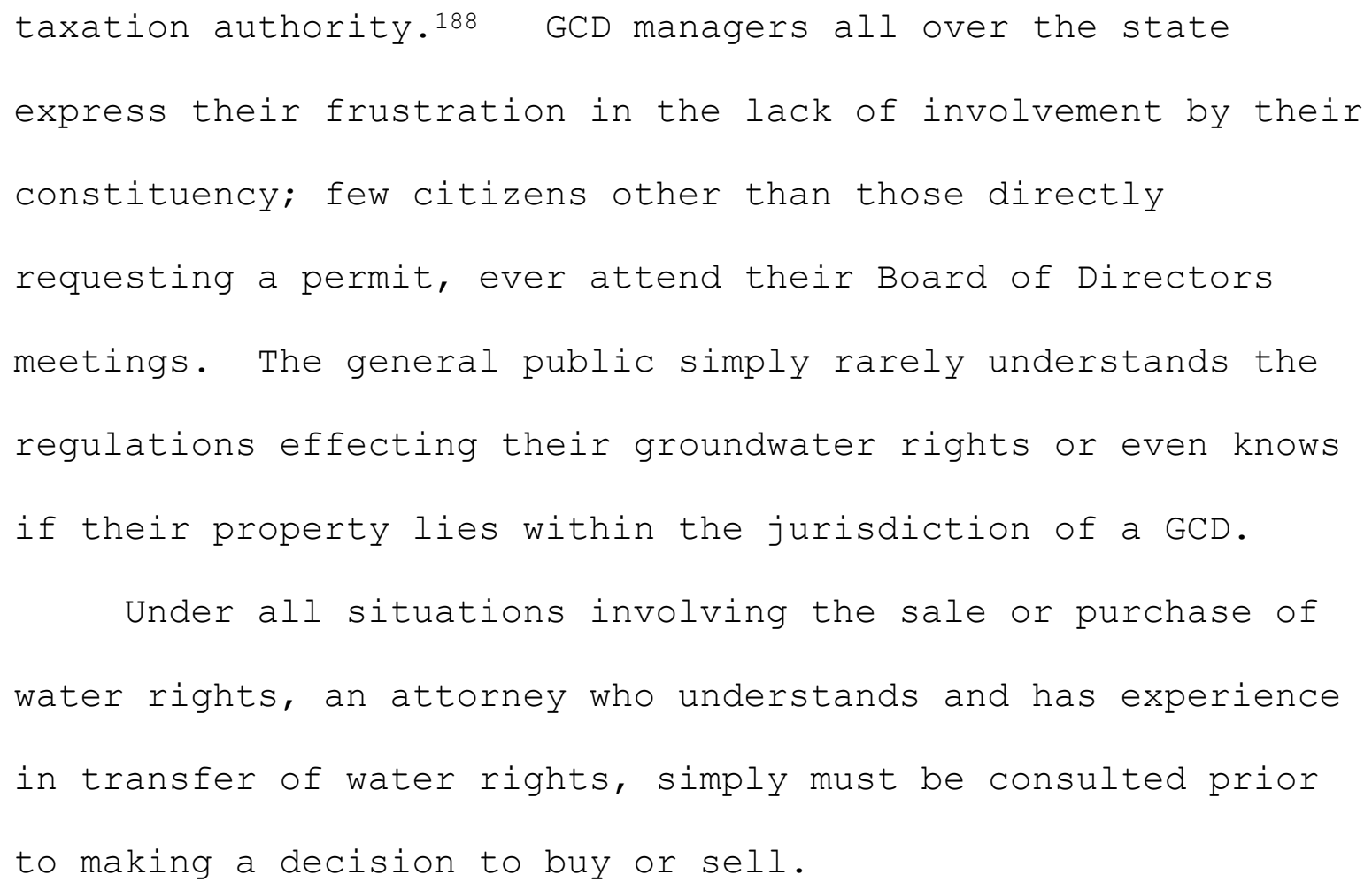

\footnotetext{
${ }^{188}$ The GCD taxing authority and tax rate is listed on all annual ad valorem tax invoices in Texas.

${ }^{189}$ Ed McCarthy joined the Law Firm of Jackson, Sjoberg, McCarthy \& Wilson, L.L.P. as a Partner in May 2003. After graduating from St. Mary's Law School in May 1981, Ed served as a Briefing Attorney on the Supreme Court of Texas. During his tenure with the Court, Ed was assigned to former Texas Supreme Court Justices James Denton (deceased) and Ruby Kless Sondock. Following his service on the Court, Ed served as a Captain in the Judge Advocate General's Corps, United States Army. During his tour of active duty, Ed was a member of the United States Army Government Appellate Division, and represented the United States in appellate matters before the United States Court of Military Appeals and the United States Army Court of Military Review. In 1985, Ed joined McGinnis, Lochridge \& Kilgore L.L.P., and became a Partner with the law firm in January 1989, where he practiced until 2003.
} 
state. On several occasions, he asked me and I accepted the opportunity to present my work to the attorneys at the continuing education conferences he chairs for the state bar. Each presentation required new research into heretofore unstudied areas of water rights, law, and policy. In the focus group, McCarthy discussed the lack of certainty and the complications of credible fair market valuation of water in Texas. He asked me to write a law journal article under his supervision on the subject which will be the first of its kind in Texas history. The following section of this study is the result of my research that stemmed directly from this request. This study breaks new ground in proposing a water valuation/marketing industry standard approach to comprehensive fair market water valuation. This market valuation model is designed so it can be adapted to any region or area on the globe.

There are traditionally three methods or approaches to determine the fair market value190 of real property,

\footnotetext{
190 "The price the property would bring when offered for sale by a seller desiring to sell, but not obliged to do so, and bought by a purchaser desiring to buy, but under no necessity of doing so as modified by evidence $\S$ 51.003(b) authorizes the trial court to consider in its discretion, to the extent such evidence is not subsumed [included or absorbed (something) in something else] in the historical definition."
}

Plains Capital Bank v. William Martin. No. 13-0337, _ S.W.3d_ (Tex. March 27, 2015) [emphasis added]; see Tex. Prop. Code §51.003., From Hirsch Westheimer, Michael D. Conner, April 9, 2015.

http://www.hirschwest.com/fair-market-value-under-texas-property-code-section-51-003/. Simply put the price a willing buyer and willing seller, neither being under any duress, will agree to in order to transfer title. 
replacement cost or cost approach, sales comparison approach, and the income capitalization approach or capitalization of the net operating income stream generated from operation of the property. One other significant method may prove very useful in the determination of credible water valuations, rulings of our courts. All four should be considered to determine the value of a water right.

The most thorough definition of fair market value is the most appropriate to use in estimating the value of water or a water right. According to William B. Bruggeman, Ph.D. and Jeffrey D. Fisher, Ph.D. ${ }^{191}$,

Market value is a key consideration when financing or investing [emphasis added] in income-producing properties. It is defined as follows:

The most probable price [emphasis added] which a property should bring in a competitive and open market under all conditions requisite to a fair sale, the buyer and seller acting prudently and knowledgably, and assuming the price is not affected by undue stimulus. Implicit in this definition is the consummation of a sale as of a specified date and the passing of title from seller to buyer under conditions whereby:

1. Buyer and seller are typically motivated;

2. Both parties are well-informed or well-advised, and acting in what they consider their best interests;

3. A reasonable time is allowed for exposure in the open market;

${ }^{191}$ William B. Bruggeman is the Corrigan Chair in Real Estate at the Edwin L. Cox School of Business at Southern Methodist University. Jeffrey D. Fisher is the Charles H. and Barbara F. Dunn Professor of Real Estate at the Kelley School of Business Indiana University. 
4. Payment is made in terms of cash in United States dollars or in terms of financial arrangements comparable thereto; and,

5. The price represents the normal consideration for the property sold unaffected by special or creative financing or sale concessions granted by anyone associated with the sale.192

This definition developed by Bruggeman and Fisher is the most appropriate for use in water valuation anywhere in the world. The following is an in depth analysis for the basis of my reasoning in opining that the Bruggeman and Fisher definition is the preferred definition of fair market value for credible water valuation.

First, the term "the most probable price" makes a very specific and realistic point to always keep in mind when offering a valuation of water; water valuation is not like traditional real property valuation as this valuation is so unique accompanied with so many variables that any price opined must be offered as "most probable." It must be kept in mind also that an integral part of a credible water valuation based upon our preferred definition is the old concept of "time is of the essence". 193 "Implicit in this

\footnotetext{
${ }^{192}$ Bruggeman and Fisher. Real Estate Finance and Investments, Fourteenth Edition. (New York: McGrawHill Irwin, 2011) 296.

193 "Time is of the essence" means that the specified times outlined and agreed upon in a sales or lease contract are vital and any delay, what constitutes a "delay" is usually determined at the buyer's or the lessee's sole discretion, could be grounds of cancellation of the contract. Buyers and lessors that need water will not and many times cannot wait for delivered acquisition of the water, hence as a seller or lessor typically has a limited
} 
definition is the consummation of a sale as of a specified date" in our preferred definition of fair market value inserts the "time is of the essence" concept.

Second, my preferred definition includes the idea that a buyer and seller is acting prudently and knowledgably. Water policies change often and are highly complicated by permitting processes, overlapping jurisdictions between federal and state agencies in surface water, and wide variance in rules of the GCDs. Added to the groundwater conservation district challenge the fact that the ways GCD boards grant permits for groundwater transfer can be quite inconsistent and unpredictable at times. Buyers and sellers of water rights today in Texas are faced with the arduous task of education into the intricacies and complexities of knowledge that is simply not readily available from any one source. For example, with 100 different GCDs each having a unique set of rules and regulations coupled with the widely variable nature of water resources around the state, acting "knowledgably" takes on a new urgency. Any water valuation must include a realistic assessment of the impact of any regulatory permitting process.

timeframe in which to prove their water being sold or leased is truly deliverable to the buyer or lessor legally and physically. 
Third, "undue stimulus" is a more appropriate way to include the impact of "duress" on either party. "Undue stimulus" takes into account not only the idea of parties being under duress but also ideas like an oil exploration company that must have water for hydraulic fracturing at the exact time it is needed. During the normality of drought west of a line just west of IH 35, duress and undue stimulus are much more likely to enter into a water valuation equation. Any valuation must be adjusted for the drought conditions at the time of the valuation in order to more credibly meet the "most probable price" goal.

Fourth, a reasonable time for the water right to be on the open market is another challenge in water valuation. This is because the market, especially in groundwater transfers, and what is a "reasonable time," can vary greatly from GCD to GCD, watermaster regions, and geographical regions.

Fifth, normal consideration without creative financing is highly germane to water valuation. The one element that would require an adjustment in the most probable price is any creative financing's impact on the agreed to price such as very short term loans without longer term loan take out commitments, seller or lessor financing, or other nontraditional underwriting criteria. Typical lenders in water rights acquisitions have enough trouble understanding the 
basics of water rights and how to properly underwrite any loan they offer to meet eventual audits from government agencies or other assessors of risk. It is very unlikely that any loan made to acquire a water right will be able to be sold into a secondary market or securitized as recent real estate loans have been.

The chemical and geological nature of water itself complicates each of these four methodologies. For example, in the traditional valuation of real estate, scientific investigation is usually limited to physical inspections of the land and improvements and defects thereto. However, valuation of water requires at the least a chemical analysis of the water quality and for commercially transferable water. The reliability, availability, and amount of the water to be sold must also be reasonably estimated based on scientific testing of the source of the water. All three geological containers of water are constantly in motion and are subject to drainage in many ways. Most groundwater does not lie in a "bath tub" like formation. Aquifers can be impacted by pressure changes that are difficult if not impossible to observe or predict.

Demand for water rights can be fickle dependent upon rainfall, the immediate needs of water buyers, and local politics. Most people forget that "demand" has two dependent 


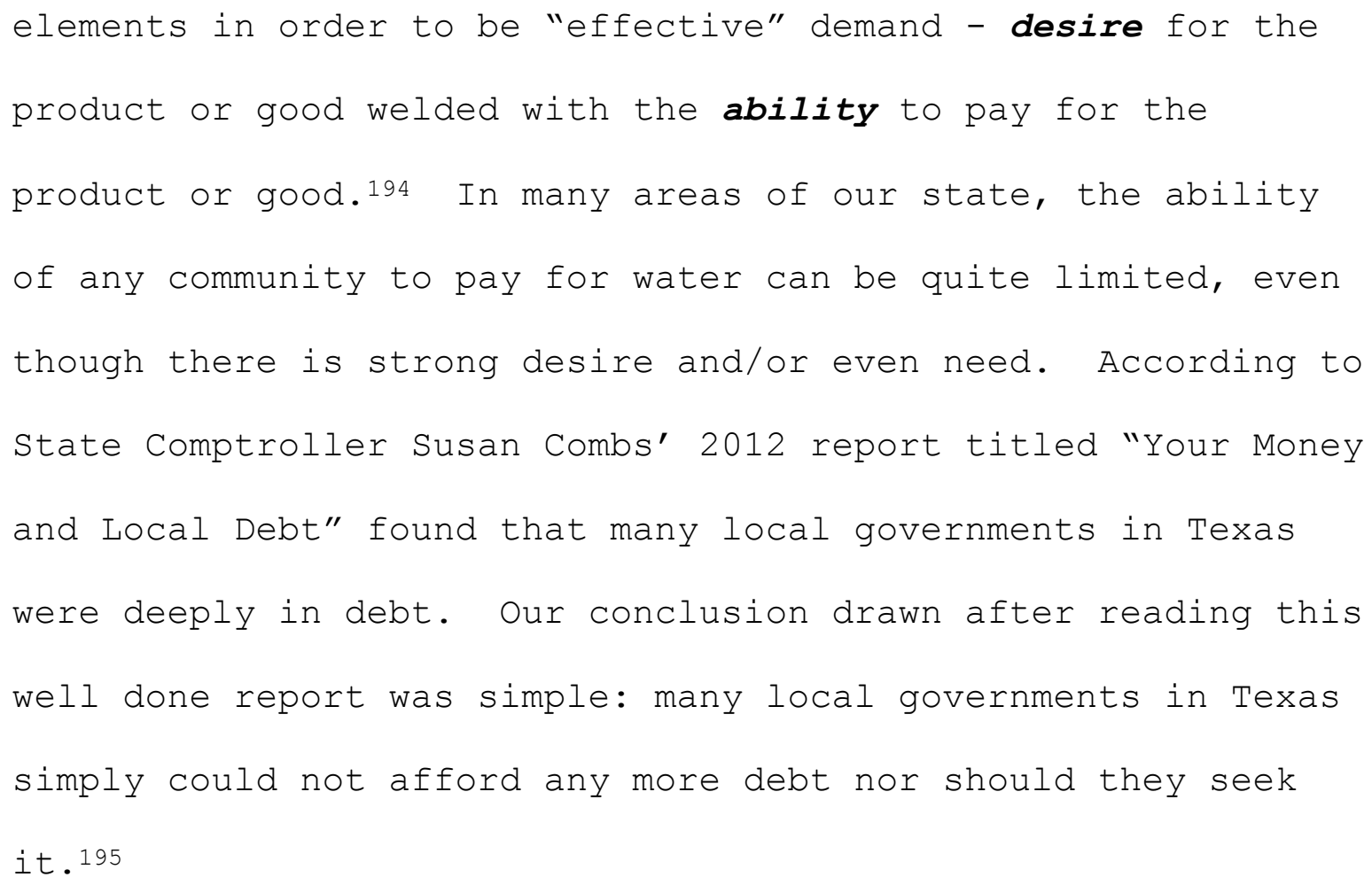

How Can It Be Determined if a Water Market Exists?

Of the most critical consideration, more so in water valuation than traditional real property valuation, 196 is if the water sold or leased is truly deliverable legally or politically. In order for a water transaction to be consummated, the water must be delivered to the buyer. Accordingly, the three groups of questions below offer a

\footnotetext{
${ }^{194}$ Sue Grant and Chris Vidler. Economics in Context.(Oxford: Heinemann Educational Providers, 2000) 28.

${ }^{195}$ www.TexasItsYourMoney.org. Susan Combs, 2012. "Local government debt has more than doubled from 2001 to 2011."

${ }^{196}$ Deliverability in traditional real estate valuation is the concept of planning and zoning regulations and processes including the impact of the political will of the people affected by any proposed real estate development.
} 
starting place to determine if a potential market for the water actually exists in any given area.

\section{Questions about transferability and deliverability.}

- Would the ability to transfer/deliver the water to the buyer from surface rights or groundwater rights be a factor in the "value" of that groundwater?

- Will the TCEQ rules allow the water right to be sold and delivered?

- Will the local GCD rules allow the groundwater to be sold or leased and transferred out of the district and in what quantity?

- Will the local people "revolt" against the transfer out of their district and cause expensive delays making the potential sale or lease infeasible and imprudent?

- Is acquisition of right of way able to be acquired in a timely manner to fulfill any sale or lease contract?

- Can a distribution system be installed including lift stations with ingress and egress from the well sites for maintenance and operations in a timely manner to fulfill the contract? 


\section{Questions about the use of the water.}

- What is the ultimate use of the water? Use of the water has a great impact on its market value. Use of the water for a corn crop or other agri-business uses surely influences the market value and generally indicates a lower value for the water. Of course, this varies from crop to crop and varies geographically. Use for bottled water or other industrial uses certainly influences the market value of the water and generally indicates a higher value for the water.

- Is the use "beneficial"?197

- Is the use of the type that will not cause subsidence?

\section{Questions about market demand, depth, and absorption.}

- Will the market be able to absorb the amount of water offered for sale or lease?

- Can the water be delivered in a timely manner to meet current demand?

\footnotetext{
${ }^{197}$ See Texas Water Code Chapter 11, Water Rights, Subchapter A. General Provisions, Sec. 11.002. Definitions. "In this chapter and in Chapter $\underline{12}$ of this code:

'Beneficial use' means use of the amount of water which is economically necessary for a purpose authorized by this chapter, when reasonable intelligence and reasonable diligence are used in applying the water to that purpose and shall include conserved water."
} 
- How "deep" is the demand, how many buyers are there?

- What factors must be considered if the water is being sold or leased to a municipality?

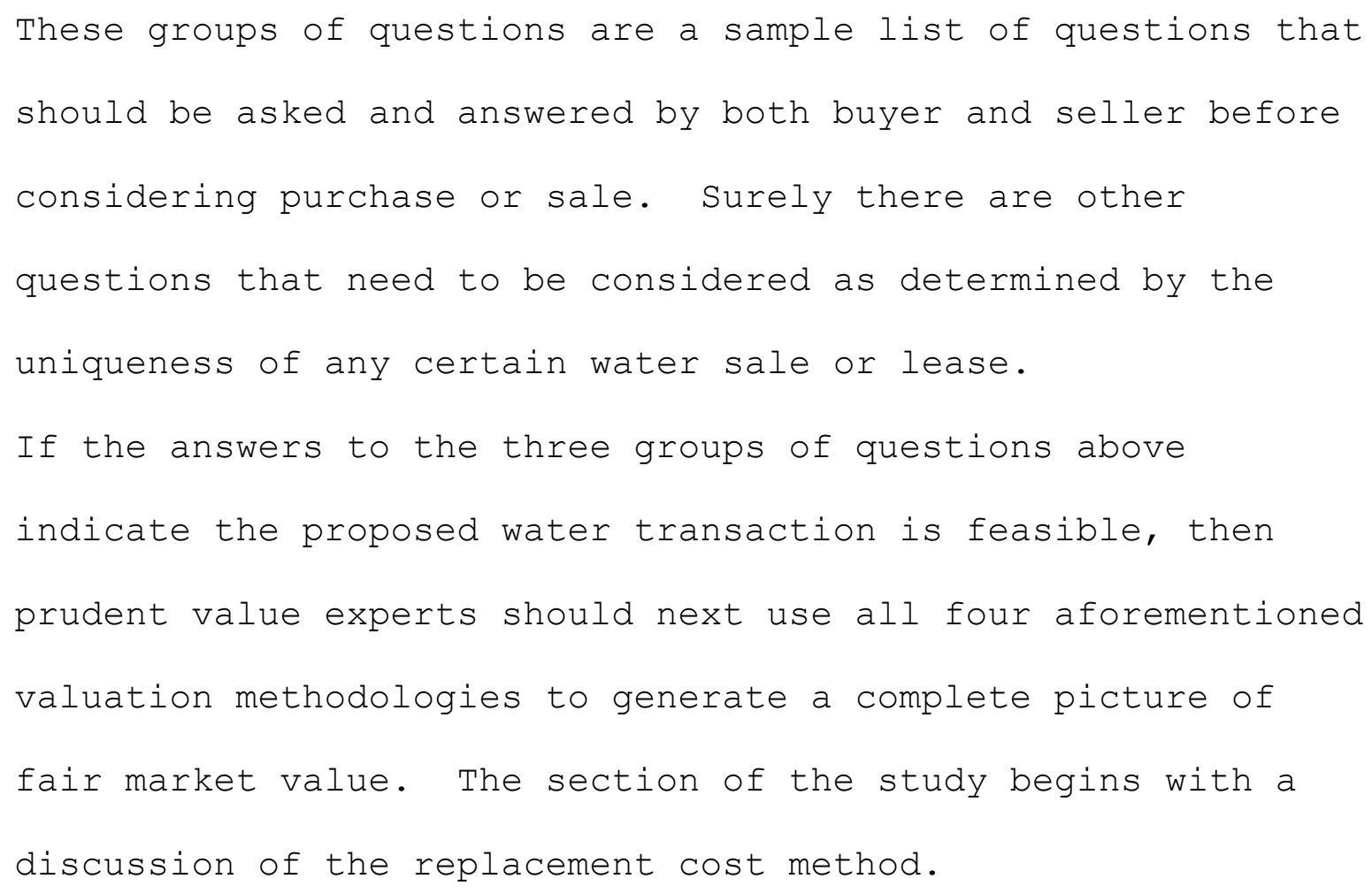

\section{The Replacement Cost Method}

How can the "replacement" cost198 of water be calculated? "Water" as a molecule cannot be rebuilt in the traditional way a real property improvement can be. But development of a

\footnotetext{
${ }^{198}$ Cost to replace an improvement assuming no reasonable person would pay more than it costs to buy the land and replace the improvement.
} 
surface or groundwater-sourced irrigation system is actually

"built" of definable parts whose the costs are readily

discernable and defendable. For example, a typical center

pivot groundwater irrigation system is comprised of these

three basic parts:

1. The groundwater well. Across the state, the cost of a well ranges from $\$ 10-\$ 35$ per linear foot in depth to the water source. This cost is highly variable dependent upon the depth of the groundwater, the geology of the strata that must be drilled through to reach the water, the cost to create ingress and egress to the drill site, the size of submersible pump required to pull the water up, and the cost of the casing to secure the drill hole. In recent years due to the strong market in scrap metals mostly purchased by China for dams and other needs, heavy steel casing has become very expensive. In fact, the largest portion of deeper groundwater wells likely will be the cost of the casing. 199

\footnotetext{
${ }^{199}$ On my ranch in Wilson, I drilled a new groundwater well in 2007. The easier and less expensive to reach groundwater on my place up to 300 feet has high levels of dissolved solids including sodium chloride (salt). It tastes bad, smells sulfurous, and while it does not kill the grass or plants, they take on a yellowish-brown tint for a good time after watering from the well. I asked my driller, Thomas Moy to quote the cost of drilling to the Carrizo-Wilcox aquifer some 1,400 feet deep on my place to reach fresher water. While the drilling cost would be around $\$ 10$ per linear foot or around $\$ 14,000$, the cost of the casing itself exceed $\$ 60,000$. I chose not to drill to that depth because I do not farm anymore. I converted my agricultural valuation to a wildlife
} 
2. The distribution system. Many modern day irrigation systems use center pivot sprinklers in lieu of canal or flood irrigation. This system pivots like a compass around a central point, usually the groundwater well itself. The cost of the equipment is based upon the length of the sprinkler arm and the type of nozzles attached.

3. The power source for the well pump. This could include a new electricity line to power the well pump or the purchase of a diesel engine.

The following is an estimate of the replacement cost of a center pivot irrigation system to provide water for an 80 acre corn field.

\section{Item}

600 foot deep well and casing

1,000 foot center pivot system

1,000 feet of electricity line

\section{Cost}

\$ 35 per foot

\$104 per foot

$\$ 5$ per foot
Total Cost

$\$ 21,000$

104,000

5,000

Total System Replacement Cost Estimate

$\$ 130,000$

valuation which has greatly improved my property and has been much more enjoyable though frankly much more difficult labor-wise than planting crops or raising livestock.

${ }^{200}$ Some sources indicate that drip irrigation systems can be built for as low as $\$ 500$ to $\$ 1,200$ per acre, if proven true, then the total amount of groundwater required would be significantly less. However, our research has found no 80 acre fields of feed corn that use drip irrigation at this time. 
How then can this cost be converted into a per-acre-foot

water valuation or replacement cost/acre-foot of water? This can be accomplished by estimating the amount of water needed to make a potentially profitable crop. According to the University of California adjusted in acre-feet instead of acre-inches, an 80 acre crop of corn requires 500,000 gallons of water per acre over the roughly six months from planting to harvesting. 201500,000 gallons per acre equates to 1.53 acre-feet per acre for this 80 acre corn crop. Assume in the example below that all the water required is provided by the irrigation system in lieu of any rainfall.

Conversion of Replacement Cost to Acre-foot Value of the Groundwater Required

Item

1.53 acre-feet of water per acre X 80 acres

Replacement cost of irrigation system

Indicated value of the water required

Indicated value adjusted for the ten year economic life = $\$ 106$ per acre foot.
Total

\author{
122.4 acre-feet water \\ $\$ 130,000$
}

$\$ 1,062$ per acre-foot 202

\footnotetext{
${ }^{201}$ University of California Drought Management adjusted for acre-feet by the authors. http://ucmanagedrought.ucdavis.edu/Agriculture/Crop_Irrigation_Strategies/Corn

202 The indicated replacement cost value in this example "expenses" the entire cost of the irrigation system in one year, likely not allowed under generally accepted accounting principles. The system could be required to be capitalized and would also be subject to depreciation. This model offers no tax considerations as the complications of any unique tax situation is incalculable.
} 
The calculations use highly conservative assumptions and indicate the water value to the $\$ 1,062$ per acre-foot. If the replacement cost of the irrigation was amortized over the very conservative 10 year estimated economic life of the system, then the indicated replacement cost value of the water is $\$ 106$ per acre-foot. An adjustment for the economic life of the water system yields a much more realistic value of the water. There are obvious and challenging adjustments that may need to be considered in the replacement cost methodology in water valuation. One adjustment to be considered is the way in which the United States Internal Revenue Service allows an individual farmer to amortize capital expenses. Another consideration is that different crops need different amounts of water. Still another consideration is the variable that some amount of rainfall during the corn crop's growing season coupled with the general moisture conditions of the land overall could require less water to be drawn from the irrigation system. The water holding ability of the soil type is another variable. Yet with all these challenges, with full disclosure by the valuation expert of all the assumptions made in a model similar to this one, a range of replacement cost values can be offered as reasonable and reliable methodology. In fact, the main point is not to make the assertion that the 
replacement cost value of the water needed to make all 80 acre field corn crops is always $\$ 1,062$ per acre-foot of $\$ 106$ per acre-foot. The model is designed to stimulate thought about the possible adjustments for the unique characteristics of any property and its water and water needs, including a reminder to consider particular farmers' individual choices such as the type of crop to be planted.

There are certain reliable resources available to hone down replacement cost to fit more exactly the unique characteristics of any given property. Agricultural extension agents around the United States are available to assist in finding any local area's cost to drill groundwater wells, purchase and install center pivot irrigation systems, and acquire electricity for irrigation systems. Public universities such as Texas Tech, the University of California, or Texas A\&M University are reliable sources for supporting data. Certainly a prudent valuation expert would also contact the local contractors and suppliers to hone down even further actual bid estimates of the cost of a local irrigation system. The seed suppliers and the implement dealers in the local area are another reliable source of data. The point made here is that any fair market valuation of water should be the result of exhaustive research into every conceivable permutation of water use. Yet another 
challenge is just that - there are an almost infinite number of permutations. However each property will be greatly influenced by local open market conditions and it is realistic that the likely number of permutations and variables could be narrowed. In any region of the world, replacement costs of a water system could be determined in a like way. This leads to the next methodology, comparable sales data.

\section{The Comparable Sales Method}

A very reliable method of fair market valuation of water is the comparable sales method.203 Finding and confirming actual closed water sales or leases in any given location or region is possible but likely will require a great deal of personal labor and a little bit of luck. Why? Water transactions typically are held highly confidential by the parties involved and there is no requirement to report to the public any details about the transaction. While the transaction is most always recorded in the real property records, rarely is the actual consideration paid stated in the transfer instrument; most transfer instruments mention the consideration not in actual dollars paid but usually described as "for $\$ 10$ and other valuable consideration."

\footnotetext{
${ }^{203}$ The sales comparison method is based on closed sales of comparable properties in our case, water rights.
} 


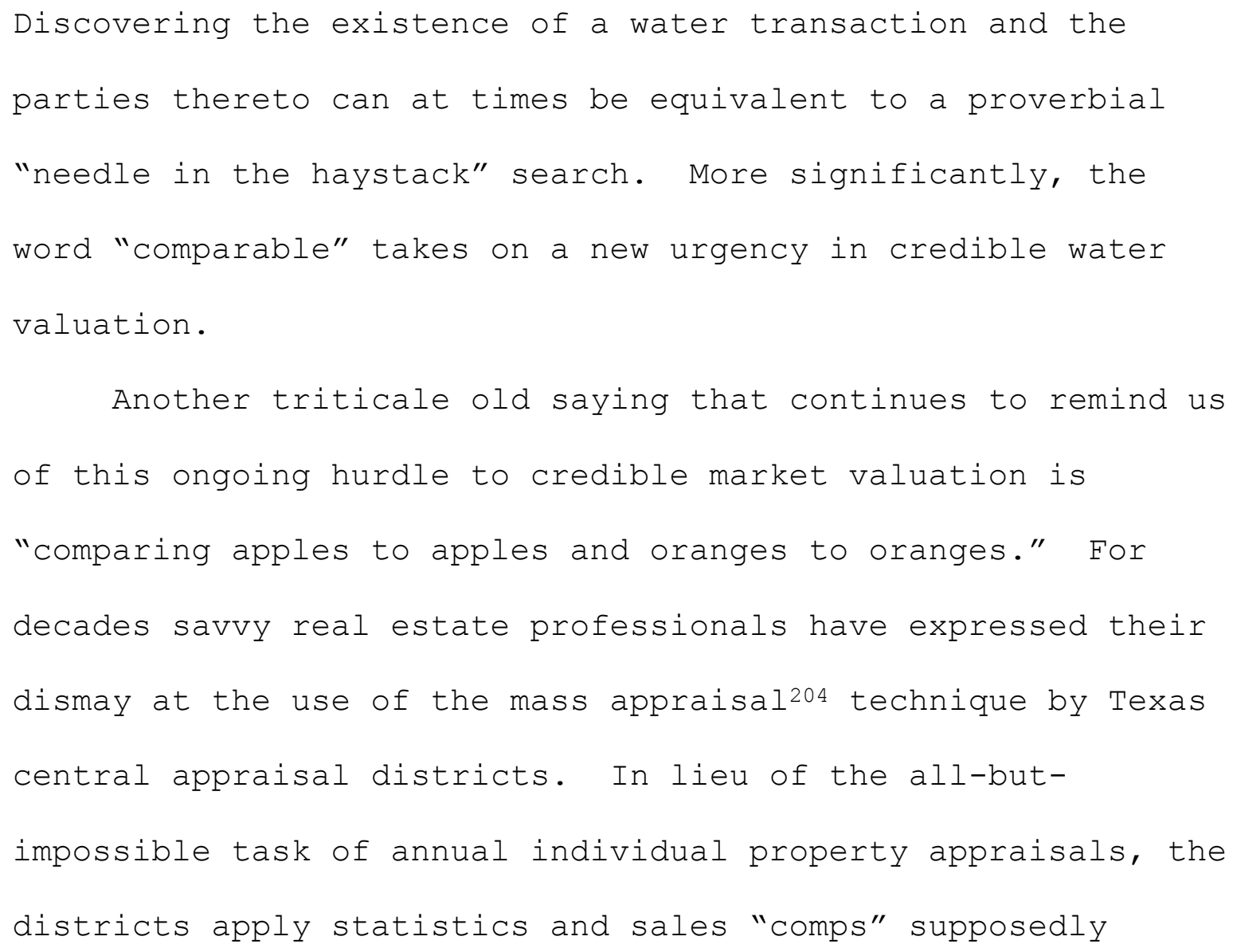

${ }^{204}$ According to "Property Tax Basics" by the Texas State Comptroller's office, "The Tax Code authorizes appraisal districts to use a method called mass appraisal to calculate the value of a large number of properties. In a mass appraisal, the appraisal district classifies categories of properties according to a variety of factors.

Using data from recent property sales, appraisal districts determine the value of properties in each class. They consider differences such as age, location and use to appraise all the properties in each class. The market value of a residence homestead must be determined solely on the basis of its current use regardless of its highest and best use. This means that your homestead must be appraised as such, even if it is located where its best use might be as the site for an office building or a parking lot for a mall. In addition, individual characteristics of property must be considered in developing appraisal models and schedules, as well as adjusting values as a result of taxpayer protests."

One of the best and most understandable definitions of mass appraisal is offered by the City of Fargo, North Dakota. Found at http://www.cityoffargo.com/CityInfo/Departments/Assessor/AssessmentProcess/MassAppraisal/ "Mass appraisal is the systematic appraisal of groups of properties as of a given date using standardized procedures and statistical testing. This differs from single-property appraisal, commonly referred to as "fee" or "bank" appraisal, which normally deals with only a particular property as of a given date.

Mass appraisal includes the application of single-property appraisals, as well as the development of appraisal formulas and statistical models, that can be applied uniformly to a number of properties at a time." 


\begin{abstract}
"uniformly" to a number of properties in an area. Mass appraisal has no place in a credible market valuation for water rights. The application of "comps" in the manner in which is allowed by the mass appraisal methodology simply could not reasonably assess the value of water. The chemical composition of the water is infinitely variable across the state. The ability for a seller to deliver to a buyer in another district or area is uniquely limited to the local rules and regulations and of course, the right of way and distribution system required to consummate the transaction. Therefore, a reliable water valuation must be made on an individual basis. Here is a brief list of basic factors in determining comparability in water valuation:
\end{abstract}

1. The chemical composition of the water;

2. The amount of water available to sell (or amount owned) and its probability of maintaining the amount purchased over the time required by the contract to purchase;

3. The rules and regulatory process required for any permit at all levels including required permits from the local GCD (if one exists), the county, the state, and 
the United States government via the Environmental Protection Agency and/or the Army Corps of Engineers;

4. The distribution system available or required to be built in order to deliver the water to the buyer which could require years of expensive right of way acquisition to build pipelines or other transfer vehicles;

5. The intended use for the water - oil and gas, agricultural, municipal, and industrial intended uses are rarely comparable; and,

6. The resistance (or support) of the local community from which the water is drawn has great impact on the ultimate valuation of the water being sold or leased.

Each of these six basic factors require diligent investigation and at times, costly professional advice and scientific testing. There are other factors that may need to be considered dependent upon the unique characteristics of any region.

To be defendable and absolutely credible, closed water transactions must first be found, then the sale or lease 
price and terms of these found transactions must be confirmed by both parties ideally or with evidentiary documentation from one party. This work requires personal interviews and determined research and investigation. Confirming comps is more about patience, politeness, and perseverance than specialized technique skills. In this regard, petroleum landmen could prove to be a very useful resource as their daily work is face-to-face negotiations with individuals after rigorous research in county real property records. How many confirmed comps are required for a credible valuation? As many as possible.

In that regard, certain recent well-publicized water transfer transactions offer a possible starting point for comparable sales and leases. One in particular is more readily available than others, the Vista Ridge water project transaction in which 3,400 water rights holders in Burleson and Lee counties agreed to lease or sell their water rights for eventually delivery to the San Antonio Water System (SAWS). The SAWS website publishes the entire contract. The transfer pipeline will travel some 142 miles to San Antonio roughly on a northeast to southwest line across central Texas. For comparable transactions in 2015, 2016, and maybe even into 2017 this water project has the potential to 
provide highly credible comps to enhance the reliability of any water valuation in a vast area of central Texas.

Another source is the San Antonio Water System or SAWS. SAWS

periodically offers the public the opportunity to offer their transferable Edwards Aquifer water rights for lease to SAWS. 205 Below are the results of a SAWS water solicitation in 2015 .

\begin{tabular}{|c|c|c|c|c|c|}
\hline \multicolumn{6}{|c|}{$\begin{array}{l}\text { SOLICITATION NO: } M-15-015-G C \\
\text { RESPONSES TO REQUEST FOR LEASE BIDS }\end{array}$} \\
\hline $\begin{array}{l}\text { Acre-feet per } \\
\text { annum offered }\end{array}$ & $\begin{array}{l}\text { First Year } \\
\text { of Lease }\end{array}$ & $\begin{array}{l}\text { Term of } \\
\text { Lease }\end{array}$ & $\begin{array}{l}\text { Price Per } \\
\text { acre-foot } \\
\text { (PPA) }\end{array}$ & $\begin{array}{c}\text { Total Lease } \\
\text { Cost }\end{array}$ & Status \\
\hline 50 & 2016 & 2 Years & $\$ 130$ & $\$ 13,000.00$ & Accept \\
\hline 8 & 2016 & 2 Years & $\$ 130$ & $\$ 2,080.00$ & Accept \\
\hline 27 & 2016 & 5 Years & $\$ 125$ & $\$ 16.875 .00$ & Accept \\
\hline 590 & 2016 & 5 Years & $\$ 170$ & $\$ 501.500 .00$ & Reject \\
\hline 40 & 2016 & 2 Years & $\$ 223$ & $\$ 17,840.00$ & Reject \\
\hline 63.148 & 2016 & 2 Years & $\$ 223$ & $\$ 28,164.00$ & Reject \\
\hline 50 & 2016 & 2 Years & $\$ 120$ & $\$ 12,000.00$ & Accept \\
\hline 150 & 2016 & 5 Years & $\$ 179$ & $\$ 134,250.00$ & Reject \\
\hline 414 & 2016 & 2 Years & $\$ 147$ & $\$ 121,716.00$ & Reject \\
\hline 268.196 & 2016 & 2 Years & $\$ 147$ & $\$ 78,849.62$ & Reject \\
\hline 414 & 2016 & 5 Years & $\$ 173$ & $\$ 358,110.00$ & Reject \\
\hline 268.196 & 2016 & 5 Years & $\$ 173$ & $\$ 231,989.54$ & Reject \\
\hline 150 & 2016 & 2 Years & 197.50 & $\$ 59.250 .00$ & Reject \\
\hline
\end{tabular}

\begin{tabular}{|c|c|c|c|c|c|}
\hline $\begin{array}{c}\text { Acre-feet per } \\
\text { annum offered }\end{array}$ & $\begin{array}{c}\text { First Year } \\
\text { of Lease }\end{array}$ & $\begin{array}{c}\text { Term of } \\
\text { Lease }\end{array}$ & $\begin{array}{c}\text { Price Per } \\
\text { acre-foot } \\
\text { (PPA) }\end{array}$ & $\begin{array}{c}\text { Total Lease } \\
\text { Cost }\end{array}$ & Status \\
\hline 414 & 2016 & 2 Years & $\$ 147$ & $\$ 121,716$ & Reject \\
\hline 268.196 & 2016 & 2 Years & $\$ 147$ & $\$ 78849.62$ & Reject \\
\hline 414 & 2016 & 5 Years & $\$ 173$ & $\$ 358,110$ & Reject \\
\hline 268.196 & 2016 & 5 Years & $\$ 173$ & $\$ 231,989.55$ & Reject \\
\hline $721 / 2$ & 2016 & 2 Years & $\$ 125$ & $\$ 18,125$ & Accept \\
\hline 150 & 2016 & 2 Years & $\$ 130$ & $\$ 39,000$ & Accept \\
\hline 40 & 2016 & 2 Years & $\$ 195$ & $\$ 15,600$ & Reject \\
\hline 320 & 2017 & 5 Years & $\$ 135$ & $\$ 216,000$ & Accept \\
\hline 440 & 2016 & 5 Years & $\$ 130$ & $\$ 286,000$ & Non- \\
\hline
\end{tabular}

${ }^{205}$ http://www.saws.org/business center/ContractSol/Drill.cfm?id=1577\&View=Yes

206

http://www.saws.org/business_center/ContractSol/IFB/1577/Table\%20of\%20EAA\%20Bids_040116\%20.pdf 
Notice the detail SAWS provides, but keep in mind the water is Edwards Aquifer Authority (EAA) water and pre-determined transferable Edwards rights under their established and accepted rules. It is interesting to note however, that the price of $\$ 125$ to $\$ 130$ per acre-foot is very close to the $\$ 106$ per acre-foot most probable price in our replacement cost method sample.

Other possible sources for comparable sales are real property record searches, title companies, county agents (Texas Agri-life Extension Agents), Farm Service Administration offices across the counties, area central appraisal districts not so much for details of water transactions but for leads from the appraisers who keep up with all real property transactions in their areas, the TCEQ, the 100 groundwater conservation districts, attorneys, accountants, hydrologists, well drillers, local newspapers, implement dealers, irrigation equipment dealers, and fertilizer and seed distributors. There certainly are many other possible sources for comparable sales. Time staking on-the-ground personal research is the key to developing a proper matrix of comparable sales or leases of water or water rights.

The recent oil boom based on hydraulic fracturing technology offered readily obtainable and confirmable water 
sale and lease comparables. For example, in the crockett County area close to Ozona, one rancher confirmed to me that he had sold his groundwater on short term contracts to oil explorers at $\$ .80$ per 42 gallon barrel of water. The sales were quick and not subject to any waiting period for permitting as oil and gas exploration activities are exempt from local permitting. The $\$ .80$ per 42 gallon barrel of water equates to a $\$ 6,207$ per acre-foot. The rancher told me that one oil company said they were willing to go upwards of \$1.00 per 42 gallon barrel in the future dependent upon the success of their drilling activities. This discussion took place in 2013 during the heyday of the shale/frack boom. Today, the boom is all but over. At best, a comparable such as this one would have a limited credible life, but in its time, no better comparable could be found. Due to the urgent demand for water and the amount needed to frack a well, in many cases, confirmation by both parties proved easier during the oil boom period. Again, the comparable sales portion of the model could be adapted to any region's facts.

\section{The Income Capitalization Method}

One of the most relied upon methods of real property valuation is the income capitalization method207 or

\footnotetext{
${ }^{207}$ According to Bruggeman and Fisher, "The income approach [method] is based on the principle that the value of money is related on its ability to produce cash flow.
} 
capitalization of the net operating income generated from the property. It is a rather simple calculation but full of its own difficulties. Once the net operating income (NOI) from a property is determined, the valuation expert simply selects a suitable market capitalization rate, commonly known as "cap rate" and divides the NOI by that rate. If the NOI is $\$ 100,000$ and the capitalization rate chosen is $10 \%$, the income capitalization method indicates a value of $\$ 1,000,000$ $(\$ 100,000 / .10)$. Like a bond, the higher the cap rate, the lower the value. The income capitalization method is based on an assessment of the risk of the investment and has its own comparables. The risk-free rate in the United States is generally recognized to be the 10 year United States Treasury Note or "bill." This risk-free rate has hovered around 2\% for the past few years. In other words, why would anyone invest in any risky project or purchase unless they are able to receive in return some multiple of the risk-free rate? Investment has opportunity costs; once capital is invested it has used up its opportunity to be inserted into another investment. Another tool in assessing investment risk is the present value of the net operating income stream, based upon discounting annual income streams based on the "time value of money". The "time value of the money" is considered in present value analysis based upon the traditional idea that 
money received now is worth more than money received later. All investors hope their money investment grows over time at some rate of return. Savvy and experienced investors seek first return of their investment and then return on their investment. Since today's risk-free rate of return is 2\%, then over time an investor, based solely upon his or her own criteria, will surely require a higher return on the money invested to adjust for the risk of any investment alternative to the 10 year US Treasury Bond. Municipal and industrial uses will likely have very specific contract terms such as price or lease rates and the net operating income can be readily determined from the duties and obligations (if any) of the seller or lessor. The rate of return required or the discount rate selected is at the sole discretion of the investor and can vary greatly. Water sales or leases have risk and that risk must be assessed in the light of the riskfree investment.

More problematic is determining the net operating income to use in the income capitalization of an agri-business product. We will use our 80 acre crop of corn example that requires groundwater irrigation to demonstrate a way the value of water can be determined using the income capitalization method. The figure below is a corn yield calculator provided by Pioneer seeds. The expected yield in 
Texas for feed corn in 2015 was around 143 bushels per acre and the expected market price was approximately $\$ 4$ per bushel.208 Inserting our 80 acre corn crop with $\$ 4$ per bushel and 143 bushels per acre, the Pioneer seed calculator indicates a net operating income of $\$ 5,159.20$, assuming the irrigation well and center pivot as well as the land is owned outright - no debt amortization costs are included! The calculator does include a machinery cost item, but keep in mind the cost of all the equipment needed includes a John Deere or equal tractor, cultivator, disk harrow, and planter. This equipment can easily cost $\$ 150,000$ or more new. For our example, we assume the equipment is owned by the producer outright and the Pioneer calculator machinery cost item equals depreciation and maintenance on all equipment used.

${ }^{208}$ Source from Texas A \& M University. 


\begin{tabular}{|c|c|c|}
\hline \multirow{2}{*}{1 Expected Market Prices } & Oorn & \multirow[b]{2}{*}{ bou } \\
\hline & 54 & \\
\hline \multirow[b]{2}{*}{2 Planted Acres } & \multicolumn{2}{|c|}{ Corn after Com } \\
\hline & 80 & acres \\
\hline 3 Expected Yleids & 143 & bulacre \\
\hline \multirow[t]{3}{*}{4 Varlable Costa } & \multirow{2}{*}{\multicolumn{2}{|c|}{$\begin{array}{l}\text { Use predetermined Varia } \\
\text { Allow me to enter my ow }\end{array}$}} \\
\hline & & \\
\hline & \multicolumn{2}{|c|}{ Com after Com } \\
\hline Fertlizer and Lime: & 153.50 & Calouinto Cocts \\
\hline Herbiclde: & 35.50 & \\
\hline Insecticide: & 23.00 & \\
\hline Seed": & 134.90 & Calouisto Cocts \\
\hline Drying & 35.52 & \\
\hline Grain Hauling: & 7.06 & \\
\hline $\begin{array}{l}\text { Prehanvest \& } \\
\text { Harvest Machinery. }\end{array}$ & 42.16 & \\
\hline Labor: & 37.05 & \\
\hline Crop insurance: & 14.60 & \\
\hline $\begin{array}{l}\text { Imigation: } \\
\text { Univ. of Neb - } 5125 / A \text { ( } 10^{2} \text { of water) }\end{array}$ & 0.00 & \\
\hline Other (interest, etc) ${ }^{-1-}$ & 24.22 & \\
\hline Total Expenees: & $\$ 507.51$ & \\
\hline \multicolumn{3}{|l|}{ Results } \\
\hline & \multicolumn{2}{|c|}{ Com after Com } \\
\hline Total Income: & \multicolumn{2}{|l|}{$\$ 572.00$} \\
\hline Market income & \multicolumn{2}{|l|}{$\$ 572.00$} \\
\hline LDP: & \multicolumn{2}{|l|}{50} \\
\hline CCP: & \multicolumn{2}{|l|}{$\$ 0$} \\
\hline $\begin{array}{l}\text { Net Income per } \\
\text { Planted Acre: }\end{array}$ & \multicolumn{2}{|l|}{$\$ 64.49$} \\
\hline Net Income: & \multicolumn{2}{|c|}{$\$ 5,159.20$} \\
\hline Total Farm Income: & \multicolumn{2}{|c|}{$\$ 5.159 .20$} \\
\hline
\end{tabular}

\section{Figure . 80 Acre Corn Crop Calculation ${ }^{209}$ \\ Courtesy Dupont Pioneer}

${ }^{209} \mathrm{https} / / / \mathrm{www}$. pioneer.com/home/site/us/agronomy/tools/production-cost-calculator 
Using the Pioneer calculator the following calculations emerge:

Net Operating Income of an 80 Arce Feed Corn Crop

at $\$ 4$ per Bushel in Price:

\begin{abstract}
$\$ 4$ per bushel $\times 143$ bu per acre $\times 80$ acres $=\$ 45,760$.
$\$ 507.51$ per acre $\times 80$ acres planting cost* $=40,601$.

Net Operating Income

$\$ \quad 5,159$.
\end{abstract}

* Out of pocket to plant corn, not including land, or the irrigation well including center pivot.

What therefore is the indicated groundwater value on the 80 acres at a 10\% cap rate? The calculation divides the NOI of $\$ 5,159$ by $10 \%$ to result in an indicated capitalized value of the crop of $\$ 51,590$. What then is the per acre-foot indicated value of the groundwater? Recall that our example assumes an 80 acre crop of corn needs 1.5 acre-feet per acre therefore, the water need is 120 acre-feet. To determine the value of the groundwater per acre-foot based upon a capitalized value of $\$ 51,590$ for the corn crop, divide the $\$ 51,590$ by 120 acre-feet of water. The result is the indicated value of the groundwater in our example is $\$ 430$ per acre-foot. 
A 10\% capitalization rate is 5 times the current riskfree rate, a conservative estimate to adjust for the risk in any corn crop. Even with irrigation, crops are subject to deluges or rain at the wrong time, insect infestations, feral hog destruction, early or late freezes, equipment breakdowns, and of course, widely variable market fluctuations which in today's globalized economy are more out of control of the American farmer than ever in history. A more conservative capitalization rate more indicative of the typical risk in a corn crop in Texas likely would be 16\%. Therefore the capitalized net operating income drops to $\$ 32,244$ (NOI of $\$ 5,159$ divided by 16\%). The value of the water needed then falls to $\$ 269$ per acre-foot $(\$ 32,244$ divided by 120 acrefeet) .

If the corn market in our example was at its peak of $\$ 7$ a bushel as in recent years, the net operating income could increase to $\$ 39,479$. Capitalizing the $\$ 39,479$ net operating income at $10 \%$ results in an indicated value of $\$ 394,790$ or $\$ 3,287$ per acre-foot of groundwater. Capitalizing the $\$ 39,479$ net operating income at $16 \%$ results in an indicated value of $\$ 246,744$ or $\$ 2,056$ per acre-foot of groundwater. A reasonable range therefore for our use of the 120 acre-feet of groundwater is from $\$ 269$ per acre-foot to $\$ 3,287$ per acrefoot. This is quite a wide range, but the calculation 
offers a model to use to determine the value of water using the income capitalization method. It also demonstrates the astounding leverage that the market price paid for the final corn product grown has on any given year's value of groundwater. Again keep in mind that a prudent valuation must be completely transparent to the audience, with all variables and assumptions clearly and concisely made available.

A key question that must be answered in our feed corn model is whether the farmer had in place at least a 120 acrefoot permit from the GCD, if the property was under the jurisdiction of a GCD. A use that emerges from our income capitalization model can be to offer an indication of the potential value of an irrigation permit for farming. Certainly, different crops use different amounts of water, but the estimates of the amount of water needed can be easily found from irrigation equipment suppliers, the fine agricultural colleges and universities in our country, the county agents, the feed/seed suppliers, and the implement equipment dealers. 
At this point the market values of water per acre-foot from the valuation models are:

1. Using the replacement cost method - \$1,062 per acre-foot of water for an 80 acre crop of feed corn adjusted for the ten year economic life of the irrigation system or \$106 per acre-foot.

\section{Using the sales comparison method - From $\$ 130$ per acre-} foot based on the SAWS leases in 2015 to a high of $\$ 6,207$ per acre-foot of water in 2013 using the water for fracking new oil wells; and,

\section{Using the income capitalization method - our 80 acre feed} corn crop indicates a range at $\$ 4$ per bushel price for the crop $\$ 269$ per acre-foot of water to $\$ 3,287$ per acre-foot of water if the farmer enjoys $\$ 7$ per bushel price for the crop.

These three methods demonstrate a wide variation in value estimates, but collectively they offer a thorough range of potential values based upon uses and market variables. The method not recognized as a traditional method is valuation based on a court ruling, but for water, this source cannot and should not be overlooked. It is safe to assume that any 
court ruling is based upon testimony from many sources and valuation experts. Therefore, it is yet another credible source of localized and very specific water value.

\section{Court Rulings and the Water Market Valuation}

There are a number of ongoing lawsuits in which the value of water is in issue, usually in the calculation of damages. Of course, the trial court's ruling on value can be appealed up the chain to the Texas Supreme Court based on the circumstances of the individual case. One advantage to using court rulings in valuation estimates is that the entire case file is available to the public and the opinion of the court is public information as well. Without a doubt, these rulings can be highly controversial, and in most cases, any valuation information may only be applicable to the locality and uniqueness of the facts of the case. However, since court rulings in our legal system set precedents, these rulings on water value have a germane and significant impact. For example, take the case mentioned previously in this study that was resolved recently, Bragg v. the Edward's Aquifer Authority (EAA). At this time the public has not been given access to the details of how the $\$ 2,500,000$ in damages were calculated, however as an indication of the use of a court ruling to color a water valuation, following is an in depth discussion of the 2010 trial court award of damages to 


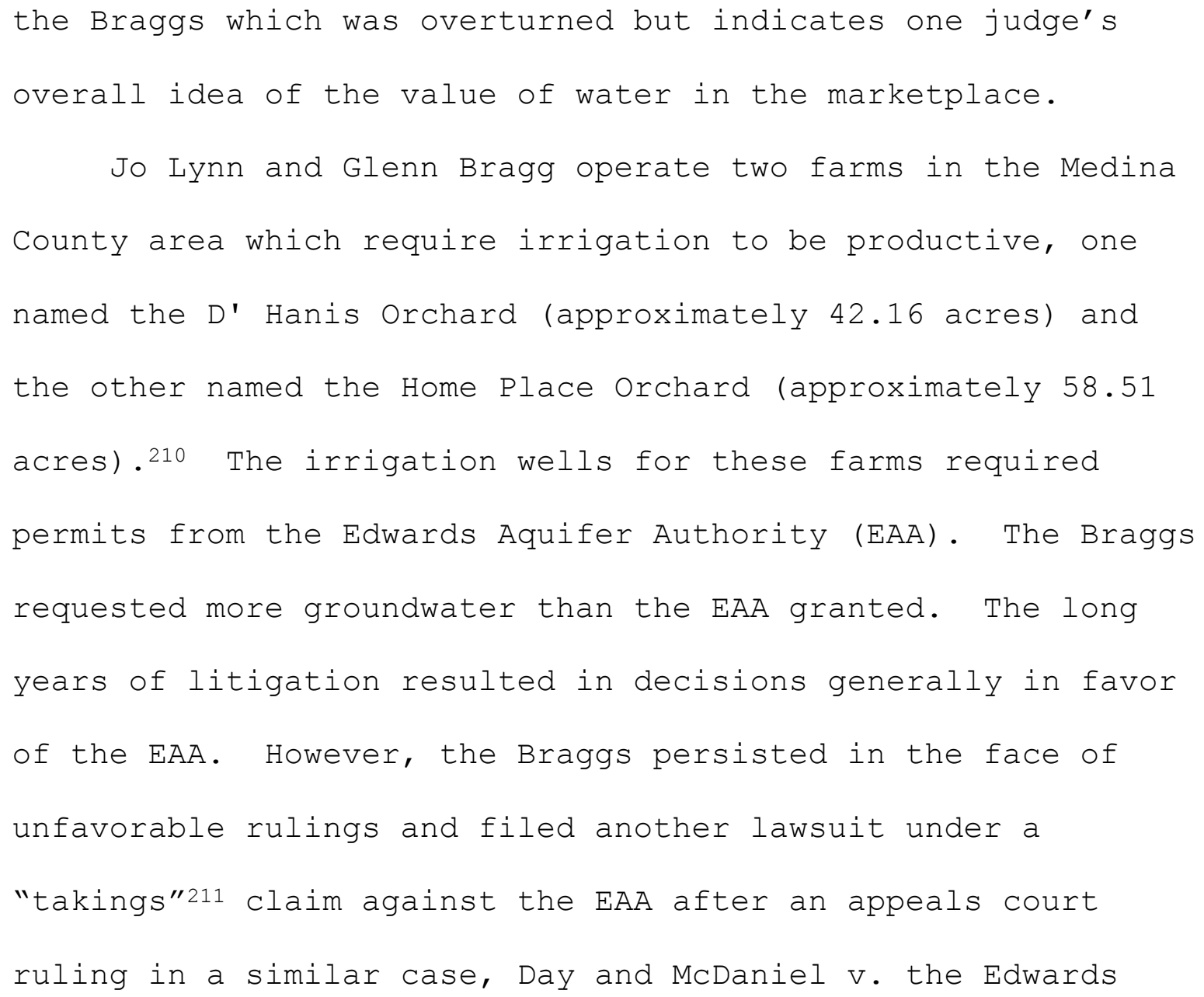

\footnotetext{
${ }^{210}$ Exact size of the farms from the Medina County Appraisal District Office. Also, see Texas Supreme Court Justice Deborah G. Hankinson's description of the farms in No. 00-0436, in the Supreme Court of Texas, Glenn and JoLynn Bragg, Petitioners v. Edwards Aquifer Authority and Gregory Ellis, General Manager of the Edwards Aquifer Authority, Respondents, On Petition for Review for the Court of Appeals for the Fourth District of Texas, Argued on October 2, 2001: "The Braggs own two commercial pecan orchards in Medina County. The first orchard is located on approximately sixty acres of land, along with the Braggs' residence and pecan processing facility. That orchard is known as the "Home Place Orchard." The scond orchard, known as the "D'Hanis Orchard," is located on approximately forty-two acres. The Braggs drilled a well into the Edwards Aquifer on the Home Place Orchard in 1979. They began drilling a well on the D'Hanis Orchard in December 1994, and completed it in February 1995." Also see Judge Thomas Lee's findings letter of May 7 , 2010 in Glenn and JoLynn Bragg v. Edwards Aquifer Authority; Cause No. 06-11-118170-CV in the 38th District Court of Medina County, Texas.

${ }^{211}$ Greg Ellis. "Regulatory Takings and Texas Groundwater" an article pending publication found at http://www.schreiner.edu/water/pdf/RegulatoryTakings\&TexasGroundwaterLaw.pdf; Also Black's Law Dictionary defines taking as "There is a 'taking' of property when government action directly interferes with or substantially disturbs the owner's use and enjoyment of the property. Grothers v. U.S., C.A.Or., 594 F.2d 740,741. To constitute a "taking, within constitutional limitation, it is not essential that there be physical seizure or appropriation, and any actual or material interference with private property rights constitutes a taking."
} 
Aquifer Authority, 212 brought up the possibility that the EAA owed just compensation for their regulatory actions. The Braggs' sought just compensation from the EAA for the amount of groundwater they were denied. Judge Thomas Lee of Hondo ruled favorably for the Braggs on May 7, 2010, with language that should awaken everyone concerned about groundwater in Texas. ${ }^{213}$

Judge Lee, a retired District Judge living in Hondo reviewed the evidence and testimony. In Judge Lee's words:

The implementation of the Edwards Aquifer Act, and the denial of an Initial Regular Permit (IRP) on February 8, 2005, for an amount less than requested or needed by the Plaintiffs to operate their Home Place Orchard, unreasonably impeded the Plaintiffs' use of the Home Place Orchard as a pecan farm, causing them severe economic impact; interfered with their investment-backed expectations, and constituted a regulatory taking of the Plaintiffs' property . . . the Plaintiffs are entitled to be compensated for their loss.214

The difference in the amount requested by the Braggs and the amount the EAA granted them was 108.65 acre-feet of water. The Plaintiffs requested that their compensation for this water would be based upon $\$ 7,500$ per acre-foot for a total of $\$ 814,875.215$ Judge Lee determined that the water was worth

\footnotetext{
${ }^{212}$ Cause No. 08-0904 in the Texas Supreme Court.

213 Judge Thomas Lee's findings letter of May 7, 2010 in Glenn and JoLynn Bragg v. Edwards Aquifer Authority; Cause No. 06-11-118170-CV in the 38th District Court of Medina County, Texas
}

${ }^{214}$ Ibid. 2.

${ }^{215}$ Ibid. 
$\$ 5,500$ per acre-foot for a total award on this portion of the damage claim of $\$ 597,575.216$ The further language he chose on page 2 and 3 seems to be written to meet the requirements that the actions of the EAA constituted a "taking." Many water rights attorneys and experts took close notice of this section of Judge Lee's ruling:

I believe this is as much about the taking away of a lifestyle as it is about the decrease in the value of land. The Braggs invested their lives, labor and money in a good family farm that could be passed on to their heirs. That life plan has been undermined, and their investment severely damaged.217

Judge Lee assigned additional damages to one tract of land, the D'Hanis Orchard, caused by the actions of the EAA. The denial of the water for this orchard no longer allowed it to be considered an "irrigated" farm. He determined that the difference between a dry land farm and an irrigated farm was $\$ 134,918.40$ or $\$ 3,200$ per acre.218 Judge Lee's total compensation award to the Braggs for both elements of damage was $\$ 732,493.40 .219$ The total acreage of the two orchards is 100.67 acres making this award $\$ 7,276$ per acre. This ruling is one cornerstone that can be used in determining the market

\footnotetext{
${ }^{216}$ Ibid. 3.

${ }^{217}$ Ibid. 2-3.

${ }^{218}$ Ibid. 3.

${ }^{219}$ Ibid.
} 


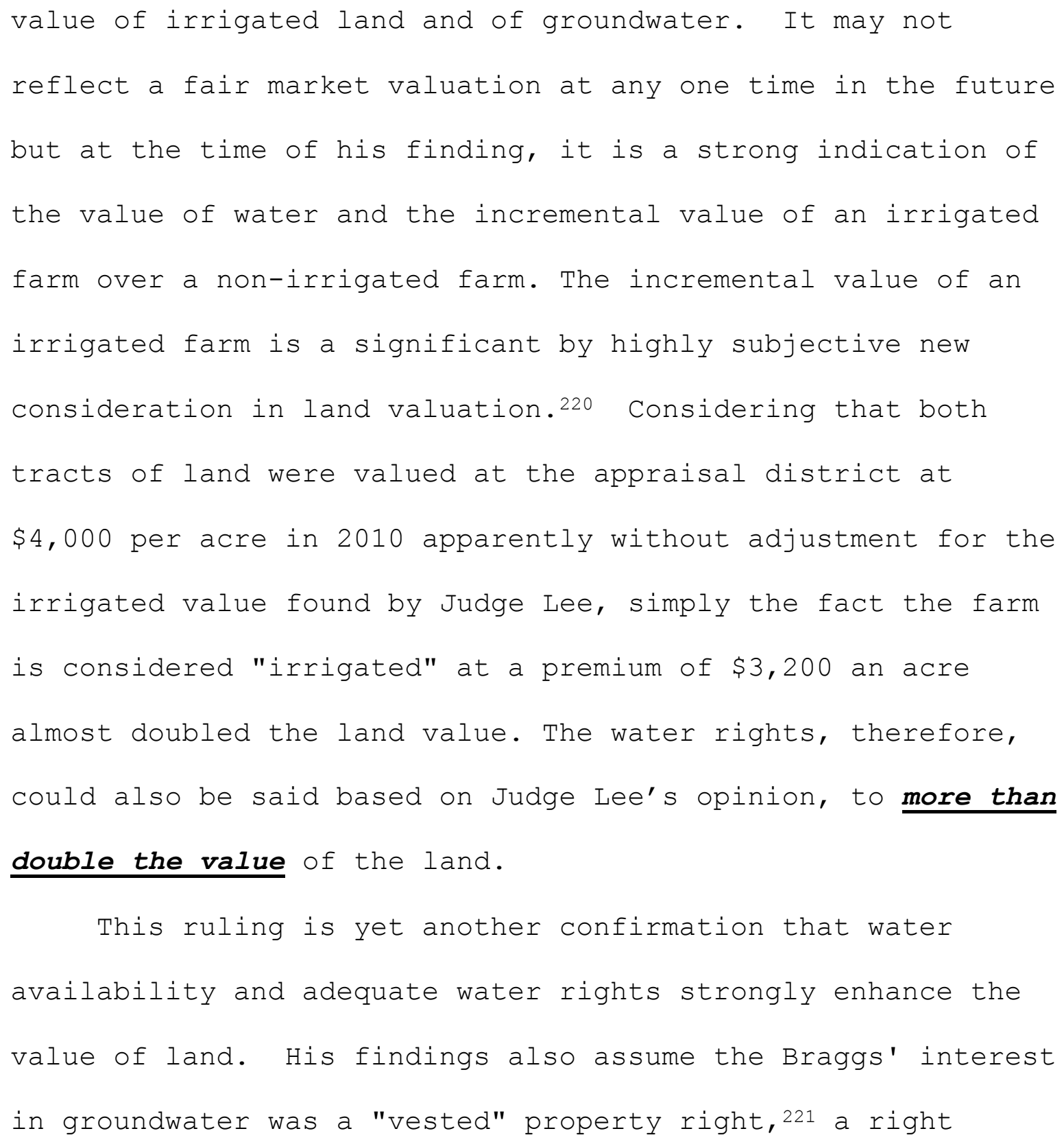

\footnotetext{
${ }^{220}$ It is highly subjective because different crops may require differing amounts of water, irrigation techniques and equipment use differing amounts of water and so on. What level of water constitutes an "irrigated farm" may be ultimately only in the mind of each individual buyer.

${ }^{221}$ Black's Law Dictionary defines "vested rights" - "In constitutional law, rights which have so completely and definitely accrued to or settled in a person that they are not subject to be defeated or canceled by the act of any other private person, and which is right and equitable that the government should recognize and protect, as being lawful in themselves, and settled according to the then current rules of law, and of which the individual could not be deprived arbitrarily without injustice, or of which he could not justly be deprived otherwise than by the established methods of procedure and for the public welfare." 1564.
} 
government has a primary duty to protect. Since water rights or the lack thereof so significantly affect land values, the characteristics and especially any defects in those rights are material and significant considerations that must be disclosed by sellers and their real estate agents to any potential purchaser of property during their decision to purchase.

Judge Lee's ruling is an indicator of the value of groundwater in 2010 in the Medina Valley/Castroville area of Texas. While his additional award adding damage to the value of the land that now could not be called an "irrigated farm" has many flaws such as a definition of an "irrigated" farm, no doubt there is some increase in value for land with an irrigation permit and irrigation system. Court rulings can be researched and can provide yet another reliable and credible source of information to value water and water rights in Texas.

The valuation of water and water rights in Texas, as well as elsewhere in the world, are beset with challenges due to the wide variability of the chemical nature of all water, the regulations affecting water including allocation and transfer, uses of the water, and the depth of the demand for water at any given time. Simple rules of thumb such as water being more valuable during drought are obvious. Not so 
obvious are the complicated sets of rules and regulations that ultimately hold the key to water sales and leases. Texas is especially challenged in groundwater sales and leases since there are 100 individual groundwater conservation districts across the state with 100 different sets of rules and regulations. Couple the variations of regulations across the groundwater conservation districts with the fact that some $25 \%$ of the state has no groundwater regulation at all since the people in those areas have chosen not to create a district, the valuation of groundwater becomes very much a distinctly local issue. Valuing surface water, allocated by the TCEQ based on first in time, first in right appropriative permits and rights, has its own challenges in quality, quantity, and transferability, but at least there is only one regulatory agency in the state overseeing its management. The federal supra-legal authority via the Clean Water Act of 1972 and the controversial and pending Waters of the United States ruling along with the various long time environmental regulations such as the Endangered Species Act of 1973 have to be considered also in water rights valuations as would EU regulations impact water's fair market value in Europe. Here are some of the sources to assist in developing a credible and reliable valuation of a water right: 
- Real estate appraisers;

- Existing sales or lease contracts - willing individuals or demands of public agencies under the "Public Information Act;"

- Real property records in the counties for recorded transfers or leases;

- Pending lawsuits and testimony from review of district court files;

- County Ag Agent and Implement/Seed Dealers;

- Court rulings such as Bragg V. EAA by Judge Tom Lee in 2010

- Petroleum landmen;

- Central Appraisal Districts;

- Individual GCDs, EAA, River Authorities, and the San Antonio Water system (SAWS) - some have "marketplace" opportunities to put buyers and sellers in touch;

- Real estate agents, attorneys, and accountants;

- Water well drillers;

- Local FSA, Farm Bureau; and,

- Open advertising by parties seeking sale or lease of water. 
Remember that there is no Multiple Listing System (MLS) for water transactions as in traditional real estate transactions, therefore difficult and time-consuming research is required into what has traditionally been the most highly confidential information, water sales and leases. But with due diligence, hard work, and a keen eye for a rapidly changing water marketplace, timely and credible valuations of water rights can be made and used appropriately.

This same fair market valuation model is germane to every society on the globe. Adjustments for currencies, crop choices, water uses, and any other appropriate adjustment for the unique aspects of any independent society must be made, but following the model's principles and formulas, the model would be an effective tool for fair market valuation of water, particularly in spain due to its similarities with Texas.

My second hypothesis, the three pillars of society can be controlled by the length of time it takes courts to resolve conflicts in public water policy, is true and correct. Justice delayed is without a doubt justice denied. The fairness and success of society with conjunctively-related three pillars depend on timely permitting, rule interpretation, and rule enforcement. "Time is of the essence" in any water project prevails. The economics of a 
water project to a large degree depend upon timely actions. The environment, especially when confronted with the danger of human folly, cannot afford to wait for unreasonable lengths of time for repair and protection. Human relationships exist within time frames and are dependent upon opportunities that come and go but rarely are fixed. The timeliness of public water policy has a tremendous impact on the three pillars of society. "Due process" social control is the manner in which any society promulgates its rules and regulations, but a key element in due process is the word "due." Due dates are part of all life as we live in a dynamic and ever-changing world, especially where water policies are concerned. 


\section{Chapter Six}

\section{"Deceptive" and "Destructive" Social Control: Water Policy Used as the Ultimate Weapon}

The third hypothesis of this study is that the three pillars of society can be controlled by promulgating formal and informal water policies as weapons to control dissident behavior or to protest other government policies. This control takes the form of "deceptive" social control as in the case of Austin, Texas or in the case of Israel's water policies towards the Palestinians and vice versa and the recent Jat caste's closing and destruction of part of the water canal delivering water to New Delhi in India, the control becomes "destructive" social control. How do these groups use public water policy or actions as weapons of social control?

Using water as a weapon of social control can be accomplished indirectly or "deceptively" as in Austin, Texas, directly or "destructively" as in the village of Beit soreek, West Bank, Israel, and recently by the Jat caste in New 
Delhi, India. The three pillars of society are dramatically affected by either approach; significant consequences for the environment, the economy, and human relationships result from both approaches. The indirect use of water as a weapon has had significant consequences for Austin, Texas since 1992.

\section{"Deceptive" Social Control in Austin, Texas}

Political groups in Texas often attempt to use water policy as a "weapon" to promote their social control agendas. Texas experiences regular droughts in varying degrees of intensity across the entire state especially west of a north south line from Dallas to Brownsville.222 The most recent severe drought in Texas began in earnest statewide in 2010.223 Texas makes an ideal example of groups using water policy as a weapon for social control because even in the midst of the latest, well-publicized, long-term severe drought, Texas continued to enjoy an enormous population increase. Demographers predict and have done so accurately for over a

\footnotetext{
${ }^{222}$ Charles Porter. Sharing the Common Pool: Water Rights in the Everyday Lives of Texans. College Station: Texas A\&M University Press, 2014.

${ }^{223}$ Charles Porter. Speech to attendees at South Texas Law School's 29th Annual Real Estate Law Conference, June 24, 2014, Houston, Texas.
} 
decade that the state's population will double over the next

50 years. 224

A central Texas group recently attempted to use water as a weapon of social control in a dispute between local

citizens and a private company seeking permits to move

privately owned groundwater out of one groundwater

conservation or regulatory district to another. ${ }^{225}$ Homemade

signs prepared and held proudly and emphatically by a local

group used an alleged statewide water "shortage" as their

weapon of social control. The signs held by this group were

seen nationwide. The group's signs proclaimed this blunt and

dire message - "Don't Come to Texas, Ain't No Water."226 It

was not a statement supported by science or true conditions

but an emotional message to discourage people considering a

\footnotetext{
${ }^{224}$ Austin Area Research Organization Luncheon December 4, 2015, attended by the author. Speaker Tom Meredith and a panel of demographers including past State of Texas demographer, Steve Murdock, agreed that the population of Texas should double by 2050. Also, see "Water for Texas: the 2012 State Water Plan." There is general consensus among all demographers that the population of Texas will grow drastically by 2050 putting tremendous pressures on all its natural resources, especially groundwater. Meredith actually predicted that the population of Austin alone would reach 8,000,000 by 2050, which is currently the population of Manhattan Island in New York.

${ }^{225}$ The tactic was used by people in Bastrop, Giddings and Lee Counties in 2014 and 2015 in an attempt to block transfer of groundwater out of district by Forestar Corporation (Bastrop) and Vista Ridge Partners, Ltd. (Giddings and Lee). Texas groundwater is partially regulated by local option groundwater conservation districts. There are 99 of these districts with 99 differing sets of regulations scattered around the state covering about $65 \%$ of the land area. Transfer out of district has been very controversial over the past decade with some lawsuits still pending after waiting years for the local courts to rule.

${ }^{226}$ Austin American Statesman. February 25, 2014. Members of the group I met in various speeches I made around Texas argue strongly that they are not really anti-growth, but only concerned citizens trying to protect their local water resources. I disagree that this is their simple and only motive; I stand by my opinion that their real motive was an anti-growth one - they want to stop new people from moving to Texas. I also stand by their right to voice that opinion.
} 


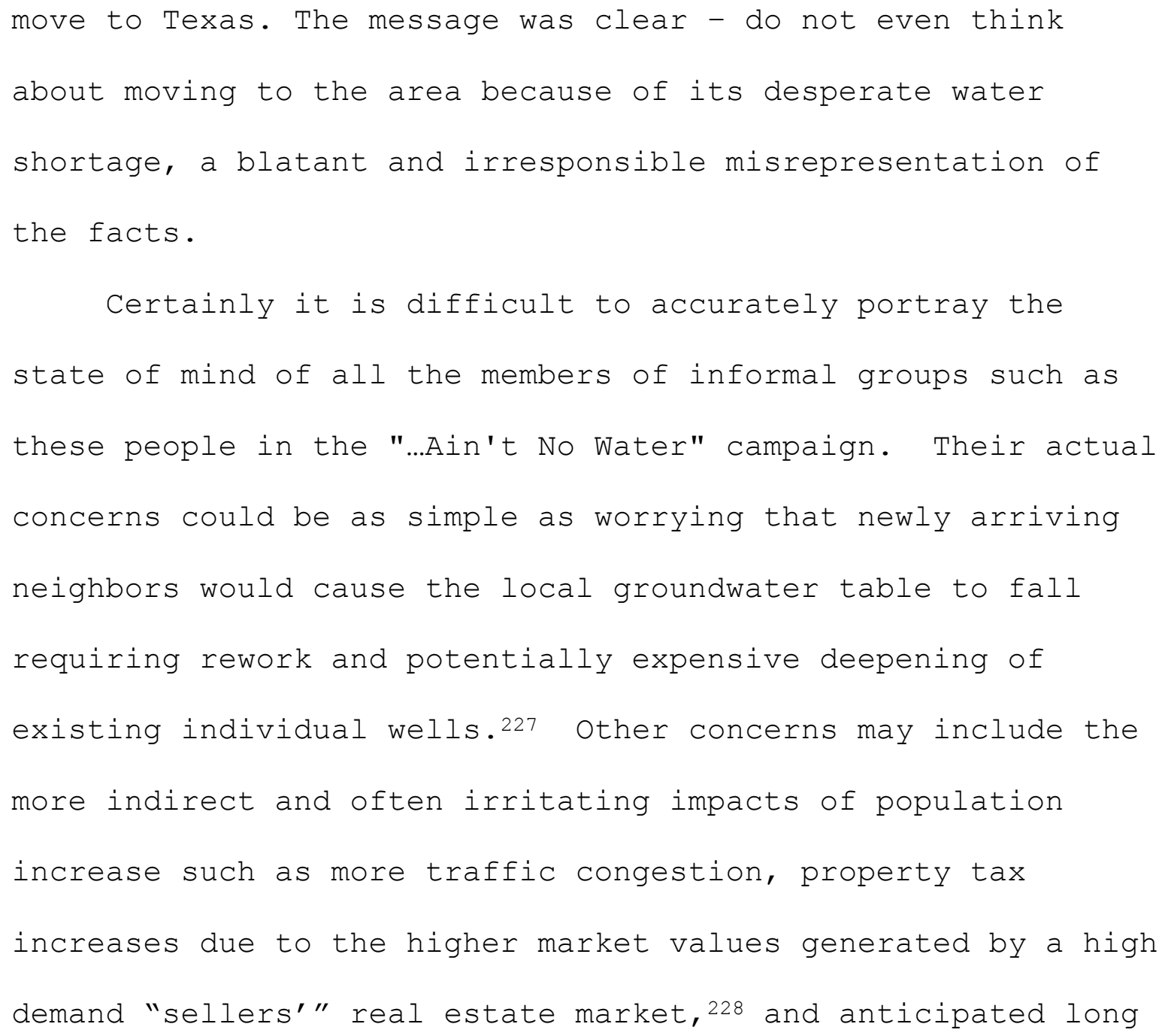

\begin{abstract}
${ }^{227}$ A rule of thumb for the cost of drilling a water well in Texas is $\$ 10$ per linear foot for the drilling and pipe casing only. This applies to wells drilled to depths of up to 500 feet. The casing cost can go up astronomically as the well depth increases due to pressures and geologic conditions. When I drilled a well on my farm, I wanted to go to 1,400 feet in depth; the drilling bid for $\$ 14,000$ but the casing that must be made of the strongest steel due to depth pressures, was a hard to believe additional $\$ 60,000$. My bid was from Moy Drilling, a 50 year old drilling company in Hobson, Texas. Why is the casing so expensive? For the past decade the international market demand for steel, mostly due to China's dam construction and other building activities, has pushed the cost of steel upwards. The smaller towns of Texas typically have a scrap metal yard. The days of the week these yards buy scrap metal usually are the most heavily trafficked days of the week in the town.

${ }^{228}$ Texas' most cherished social value since 1840 and even before, is a free education for children through the 12th grade financed mostly by ad valorem taxes based upon mass appraisals to render "fair market values" of real estate annually. The huge increase in population Texas has experienced in the past 5 years, a trend that shows no indication of ending soon, has increased the closed sales prices of residential properties as much as $8 \%$ annually - some regions such as Austin enjoyed an $11 \%$ increase in 2015 . Until Texas citizens reach the age of 65 , their property values float with the market value based on these appraisal-generated renditions annually. Traffic in some areas of Texas has become nightmarish, especially along the IH-35 corridor in
\end{abstract}




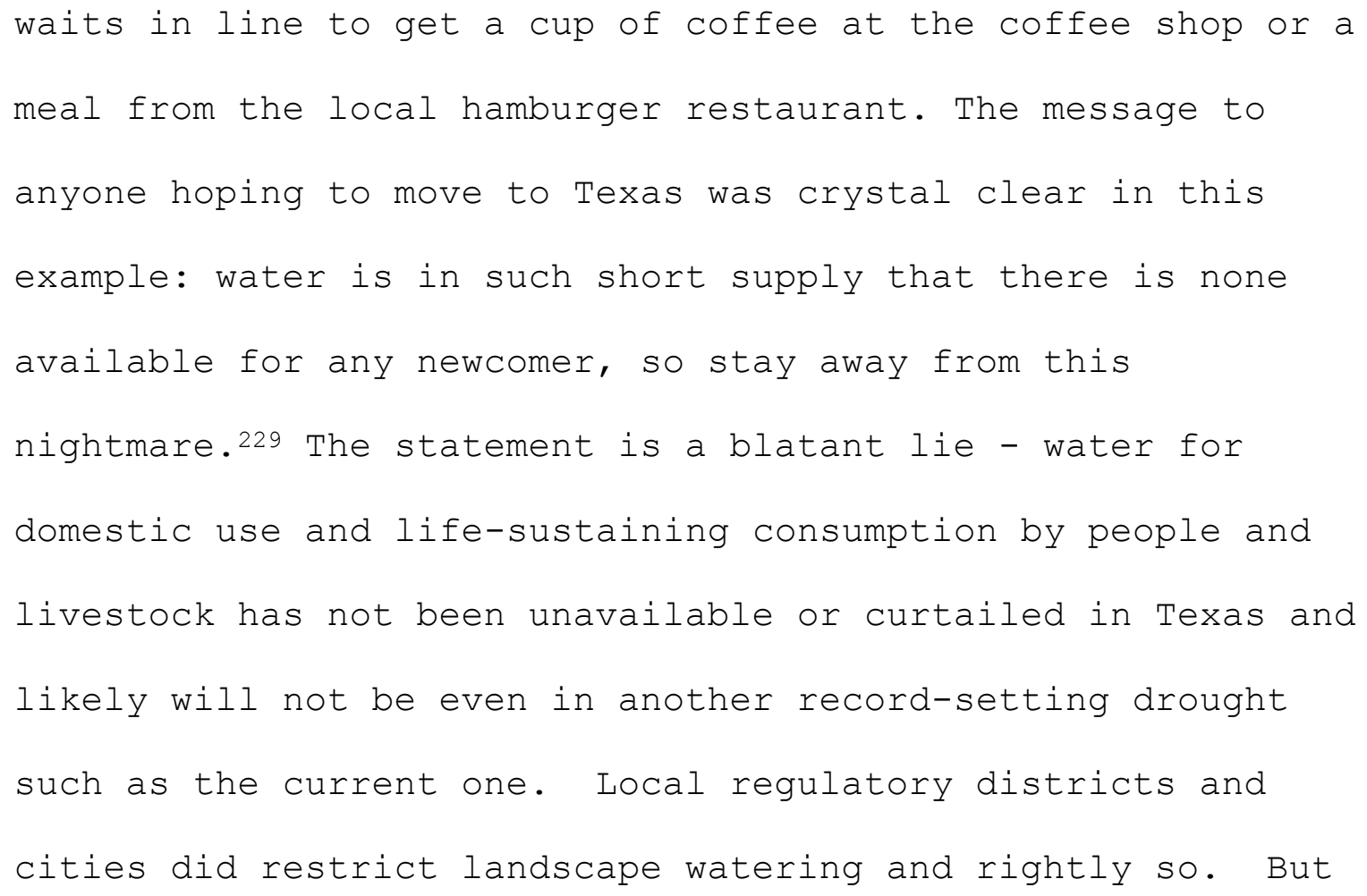

central Texas. All typically available local services can be heavily impacted from time to time, from season to season severely by expanded population resulting in long lines and delays.

${ }^{229}$ The earliest record of a group using water as a weapon of social control in Texas history occurred in December, 1731 in Villa San Fernando, Spanish Colonial village that would become the $7^{\text {th }}$ largest city in the United States, San Antonio. By 1731, missionary Franciscans had established two missions on the San Antonio River, Valero (commonly known as the Alamo) in 1718 and San Jose in 1720. Upon notice of the pending arrival of three new missions and settlers from the Canary Islands, the President of the missions, Father Vergara wrote the Viceroy Juan Acuña in Mexico City that there was simply not enough water for the any of the new missionaries and their Native Americans and especially not enough for the Canary Island immigrants. On December 25, 1731, the Viceroy responded with the first written water policy in what would eventually become the state of Texas. Viceroy Acuña wrote that not only was there adequate water supplies available to the people already living there, but also for all the newly arriving settlers. He decreed that if any water shortage would happen to occur in the future, the water in the river would be shared by all, irrigation waters would be taken in turn, and the water would be conserved by all. This is the first time in Texas history that anyone tried to use water as a weapon of social control. Viceroy Acuña was correct and stood on the many eyewitness reports made from the area in the late $17^{\text {th }}$ and early $18^{\text {th }}$ centuries that there was an amazing amount of fresh water in the river fed from the prolific springs. One report in particular, written in 1709 after a personal visit to the area by the then President of all the Queréteran missions, Franciscan Father Isidro Felix Espinosa, said there was not only enough water for a villa on the San Antonio River, but enough for a ciudad (city). See Spanish Water/Anglo Water by Charles Porter, (College Station: Texas A \& M University Press, 2009) and "Querétaro in Focus: the Franciscan Missionary Colleges and the Texas Missions" by Charles Porter in Catholic Southwest, A Journal of History and Culture, 2008, Vol. 19, pp. 9-51. 


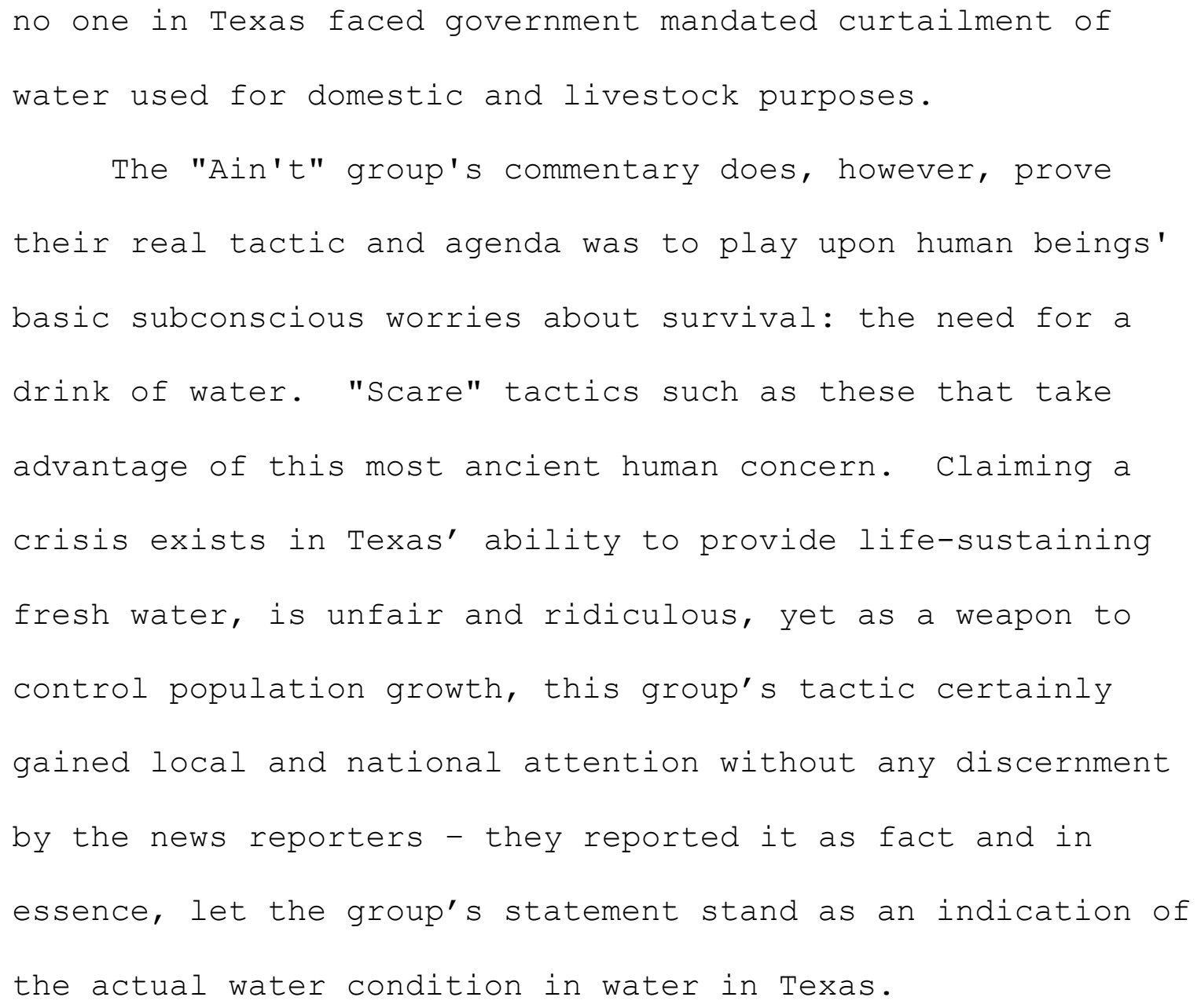

\section{A Subtle Example at a Local Water Forum}

Another more subtle example of an attempt to use water as a tool for social control statewide occurred at the 4 th Annual Lone Star Water Forum in Brenham, Texas in October, 2012.230 Well known central Texas attorney Bill Bunch, Executive Director of the Save Our Springs Alliance in Austin

\footnotetext{
${ }^{230}$ The Lone Star Water Water Forum is a water inquiry forum organized by Brenham, Texas citizens and supported by Texas A \& M University's Agri-Life Extension Office, numerous local citizen and environmental groups, the City of Brenham, St. Edward's University, and the Texas Wildlife Association. The 8th Forum will be held in 2016. I was a speaker at four of the forums from 2012 to 2015. I also serve on the Board of Directors. I spoke that day in 2012 immediately after Bunch as he and I shared the podium. My work here is based upon my notes during his speech.
} 


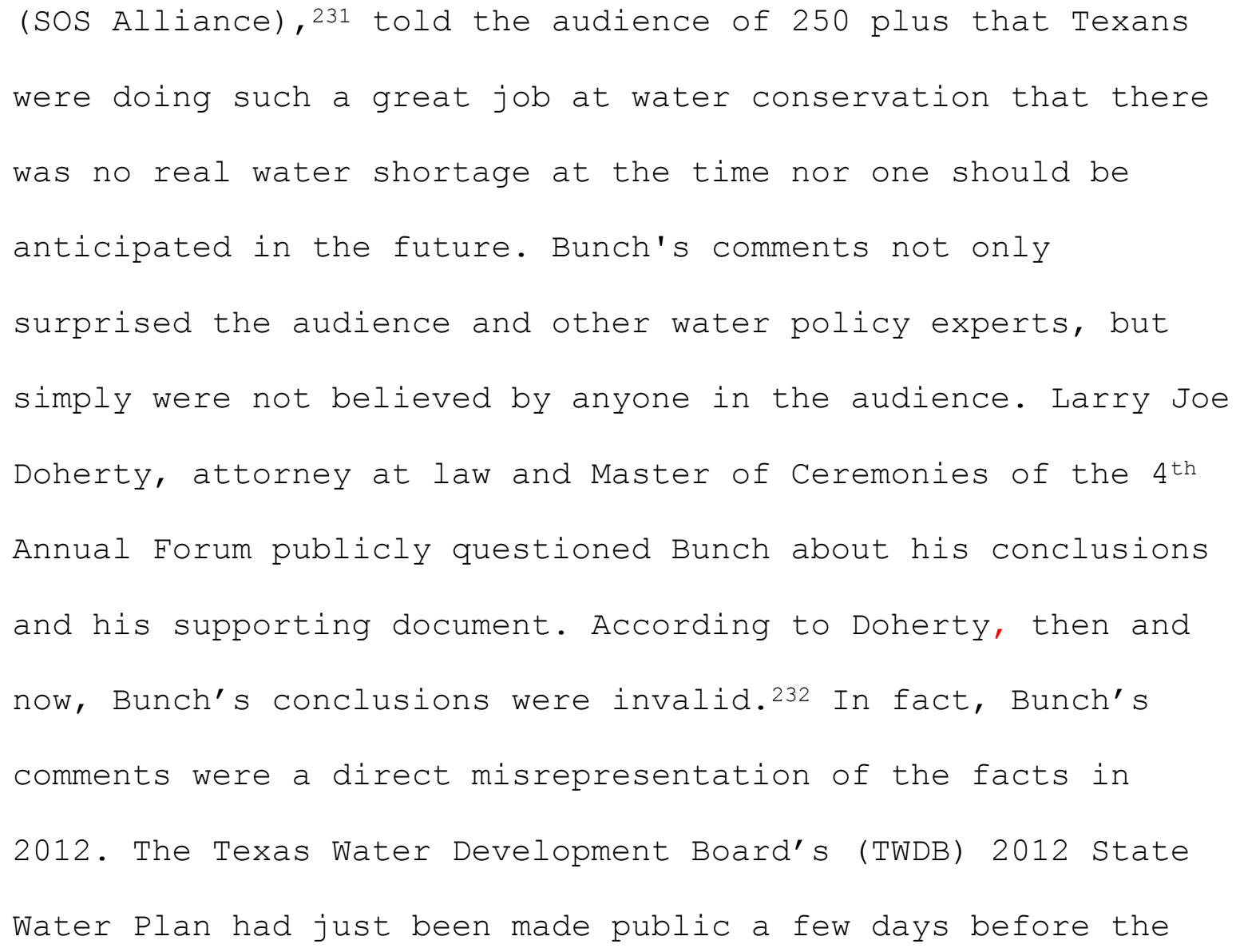

231 From their website, "The Save Our Springs Alliance works to protect the Edwards Aquifer, its springs and contributing streams, and the natural and cultural heritage of the Hill Country region and its watersheds, with special emphasis on Barton Springs. The Save Our Springs Alliance sprung to life in 1990 as a loose coalition of citizens fighting a massive development proposal for the Barton Creek watershed. On June 7, 1990, more than 1000 citizens signed up to speak to Austin city council in opposition to the planned 4,000-acre Barton Creek PUD. After an all-night meeting, council unanimously rejected the PUD, and a movement began to strengthen the 1986 Comprehensive Watersheds ordinance under the acronym SOS: "Save Our Springs". Organized in 1992 as the Save Our Springs Coalition, we wrote and petitioned for the Save Our Springs Ordinance to protect the quality of water coming off of development in the fragile Barton Springs watershed. With the voter approval of the SOS Ordinance, developers went on the attack at the court house and the Texas Capitol. We incorporated as the Save Our Springs Legal Defense Fund in 1993 to defend developers' attacks on the SOS Ordinance. Expanding our scope to include building awareness and alliances throughout the Austin area, we became the Save Our Springs Alliance in 1997. We routinely work with local conservation groups to advocate for the protection of Barton Springs and the Edwards Aquifer."

See http://www.sosalliance.org/community/about-s-o-s-alliance.html .

${ }^{232}$ I was an eyewitness to Doherty's questions, Bunch's answers, and the audience's non-acceptance of Bunch's conclusions. In fact, I shared the podium with Bunch that day having made my presentation immediately before Bunch offered his. I discussed Bunch's comments then many times with Larry Joe over the past few years, most recently on June 27, 2016 and arrive at the same conclusion. Well- known attorney John Muegge attended the forum that day and agreed with Larry Joe and me about the weakness of Bunch's presentation. 
forum. The cover letter written by TWDB Chairman Ed Vaughn

could not have been clearer - in drought conditions, there

was not enough water available to meet the needs of Texans in

the near future and beyond. ${ }^{23}$ The 2012 official state report

mentioned several times that there was not enough water

available in Texas to meet the state's anticipated growth

over the next 50 years supported by professional expert

opinions and science.

Bunch's dedicated work as a steward for water

conservation in central Texas was then and still is

unsurpassed by few and he deserves praise and thanks. Yet his

speech that fall day in Brenham centered on only one thought,

surprisingly based on an out of date comment made in a past

Texas Water Development Board ${ }^{34}$ report. Bunch held up a

single copied page from an unspecified report showing a small

line graph allegedly claiming that the state agency's

official opinion was that water conservation was being

accomplished so well by Texans that there was no need for the

\footnotetext{
${ }^{233}$ Bunch mentioned 2007 in his speech as the date of the graph. However, the Texas Water Development Board's 2012 State Water Plan had just been made public. The cover letter written by TWDB Chairman Ed Vaughn could not have been clearer - in drought conditions, there was not enough water available to meet the needs of Texans. The 2012 official state report mentioned several times that there was not enough water available in Texas to meet the state's anticipated growth over the next 50 years. The TWDB by state law must write an updated State Water Plan every five years.

${ }^{234}$ From their website, "The Texas Water Development Board's (TWDB) mission is: To provide leadership, information, education, and support for planning, financial assistance, and outreach for the conservation and responsible development of water for Texas." See http://www.twdb.texas.gov/about/index.asp\#twdb-history .
} 
state to focus on finding new water resources for the future. To put it simply, Bunch's message was that Texans were conserving themselves out of any future water worries Texans had plenty of water for the state's future. Again, a message using water as a weapon for social control. Why did he take this approach? Bunch not only works to protect water resources for over two decades in central Texas, but also works less openly to control population growth by restricting new development in watersheds and aquifer recharge zones. His opinion that day was not based upon credible science - he offered no scientific support for his opinion.

Bunch's remarks contained a hidden agenda for his ongoing anti-growth position - try to limit growth in Texas by persuading the people there was no real shortage of water in the state therefore no new water resources for the future were needed to be considered or put into place by Texas government. His remarks were a feeble attempt to begin to change the public discourse to discourage future population growth in the state with his full knowledge and hope that future water shortages would be made worse by poor planning by the state government. If the state did not develop a plan for new water resources then population growth would doubtlessly have to slow statewide. What responsible person or company would move to a Texas without water? What 
institution would invest in state of municipal bonds in

Texas?

\title{
Local Ordinances and Regulatory Proposals to Limit Growth Using Water Policy as a Weapon
}

\author{
Bunch's Save Our Springs Alliance group was originally \\ formed in 1990. It is another local example of a grassroots \\ movement to attempt to exert social control using water as \\ the main weapon. The group authored and promoted Austin's \\ Save Our Springs Ordinance (SOS Ordinance) of 1992. The city \\ held an election in August 1992 and the sos initiative, as \\ the future ordinance was originally called, passed \\ overwhelmingly with $64 \%$ of the voters approving the idea.235 \\ The ordinance promulgated stringent low-density controls on \\ almost 100 square miles of the near downtown southern and the \\ western areas of the city. The ordinance accomplished this
}

\footnotetext{
${ }^{235}$ Texas Water Resources Institute - New Waves - The Research Newsletter, Volume 5, Number 3, October 1992. See also http://www.austinchronicle.com/news/2002-08-09/99632/:"The Barton Creek watershed is the 120-square-mile area within which surface water drains into the creek. Any rain that falls in this area makes its way to the creek, unless it soaks into the ground and goes down to the aquifer, and any pollution or impervious cover development in this area will degrade the water quality in the creek.
}

Aug.: In Aug. 8 [1992] election, Austin voters overwhelmingly approve the Save Our Springs ordinance, as well as bonds for the BCCP and Barton Creek Wilderness park. SOS ordinance is applicable to Barton Springs Zone of the Edwards Aquifer, a small part of the overall watershed southwest of the city, limiting development in that zone to a maximum of $15 \%$ to $25 \%$ impervious cover, and mandating that stormwater runoff be as clean after development as before.

City records reflect that 277 development applications have been filed covering 12,000 acres in the Barton Springs Zone -- all but 38 of them after the time council delayed SOS initiative election from May 2 to Aug. 8 , and almost half on behalf of two developers: Jim Bob Moffett and Gary Bradley. Developers contend that plans are governed by earlier, less restrictive regulation." 


\begin{abstract}
by limiting allowable "impervious cover"236 for any new
development to only 15\% of the total land area in the

recharge zone, 20\% in the contributing zone for Barton Creek, and $25 \%$ for the remaining portion of the contributing zone. ${ }^{237}$

The impervious cover restriction ostensibly was to protect

the recharge zone of the source aquifer of Austin's landmark

Barton springs thereby protecting the springs themselves.238

The impervious cover restriction in the ordinance effectively

limited growth to such an extent that most new and proposed

development in the sos jurisdictional area basically stopped

- few new homes were built and new commercial properties were

all but eliminated. The typical new residential subdivisions

that were built post-SOS had such low-density that the homes

were unaffordable to all but the wealthiest of Austinites.

An unintended consequence of the sos Ordinance was to

reduce the ad valorem tax base by millions of dollars across
\end{abstract}

\footnotetext{
${ }^{236}$ According to the City of Austin Municipal Code 25-8-1-10, "IMPERVIOUS COVER means the total area of any surface that prevents the infiltration of water into the ground, such as roads, parking areas, concrete, and buildings."

${ }^{237}$ This is the generally accepted maximum for research, but based on set backs, compatibility requirements, and other conditions, the impervious cover limitation may drop to less than the posted percentages of allowable impervious cover.

${ }^{238}$ Barton Springs is a natural set of springs just south of the Colorado River in downtown Austin. There are four springs that create the "springs" and has been a favorite swimming area for time eternal. It is the centerpiece of the 358 acre Zilker Park now the venue for Austin City Limits, a worldwide festival of live music. Barton Springs Swimming Pool is 3 acres in size and has a natural limestone and gravel bottom filled with very cold spring water. It is home to the endangered Barton Springs Salamander. In the 1920s the city dammed Barton Creek just below the springs to create the famous swimming pool. In the 1940s the city built the bathhouses that remain in use today.
} 
the ordinance's boundaries resulting in, 24 years later, tens of millions of fewer dollars for schools, hospitals, and other public services. ${ }^{239}$

Beginning with the Republic of Texas (1836-1845), when Texas was briefly an independent nation, and continuing to this day, a free public school education through high school has been one of Texans' most accepted social values. When large areas of land are so limited by impervious cover restrictions such as those set by the sos Ordinance that they cannot be normally developed, the general revenue available to fund education creates a social value conflict that must be debated including consideration of financial consequences. The debate must examine issues based on scientific fact, not emotions and coercion.

\footnotetext{
${ }^{239}$ Austin's combined ad valorem tax rate has remained at $\$ 2.43$ per $\$ 100$ valuation for several years. The Austin Independent School District tax makes up about $\$ 1.25$ of this overall rate. The remaining tax rate is made up of special district taxes, hospital taxes, and other voter approved public service taxes.
} 


\section{$\underline{\text { Impervious Cover Limitation }}$}

Tract Size -6 acres $=$

Allowable impervious cover

Rentable square footage of building (37.5\% of allowable impervious cover)

Annual Net Operating Income at \$20/sq. ft.

Indicated Market Value of Development

(Capitalize Net Operating Income at 8\%) $\underline{65 \%}$

261,360 sq. ft.

169,884 sq. ft.

63,707 sq. ft.

$\$ 1,274,140$

$\$ 15,926,750$ $\underline{15 \%}$

261,360 sq. ft.

39,204 sq. ft.

14,702 sq. ft.

\$294,040

$\$ 3,675,500$

Difference in Indicated Market Value

$\$ 12,251,250$ or $\$ 2,041,875$ per acre.

Loss of Ad Valorem Tax Revenue at the Tax Rate of \$2.43 per \$100 Valuation

\section{$\$ 297,705$ annually or $\$ 49,618$ per acre.}

Loss of Ad Valorem Tax Revenue over 20 years (Assuming No Increase in Market Value)

\section{$\$ 5,954,100$ or $\$ 992,350$ per acre.}

Assume the potential acreage in commercial sites inside the $15 \%$ impervious cover allowable SOS Ordinance Area is 600 acres. The SOS 15\% area comprises approximately 25 square miles or 16,000 acres; 600 acres is only $3.75 \%$, a conservative estimate of potential development area for a population of almost $1,000,000$ in a city such as Austin.

Total Potential Lost Ad Valorem Tax Revenue

$\$ 29,770,500$ per year or

$\$ 595,410,000$ over 20 years.

Figure 5. Ad Valorem Tax Revenue Loss of SOS Ordinance ${ }^{240}$

\footnotetext{
${ }^{240}$ Please see Appendix 3 for proof of the sole originality of this study's research; no one has published any academic peer-reviewed articles other than the author, Charles Porter in the Research in Business and Economics Journal, article 162390, of the Academic and Business Research Institute.
} 
Figure 5 above is an analysis of the impact of impervious cover limitations on the after-development value a small typical commercial property (either retail or office) on only a six acre tract and over 600 acres of potential commercial developments in the sos Ordinance area. ${ }^{241}$ Over the first 20 years, $\$ 1,225,125,000$ in total market tax base valuation was lost due to impervious cover limitations of the ordinance. At the combined tax rate, the amount of tax revenue lost annually equals $\$ 29,770,500$. Considered over a 20 year period, the total minimum estimated ad valorem tax revenue loss is $\$ 595,410,000$. An average net operating income of $\$ 20$ is reasonable and realistic considering the location of the original 25 square miles of sos jurisdiction. The following figure demonstrates the loss of ad valorem tax revenue from the worst to the best case scenario.

\footnotetext{
${ }^{241}$ The assumption of 600 acres is very conservative and equals a retail or commercial corridor or only 5 miles in length on both sides of the thoroughfare.
} 


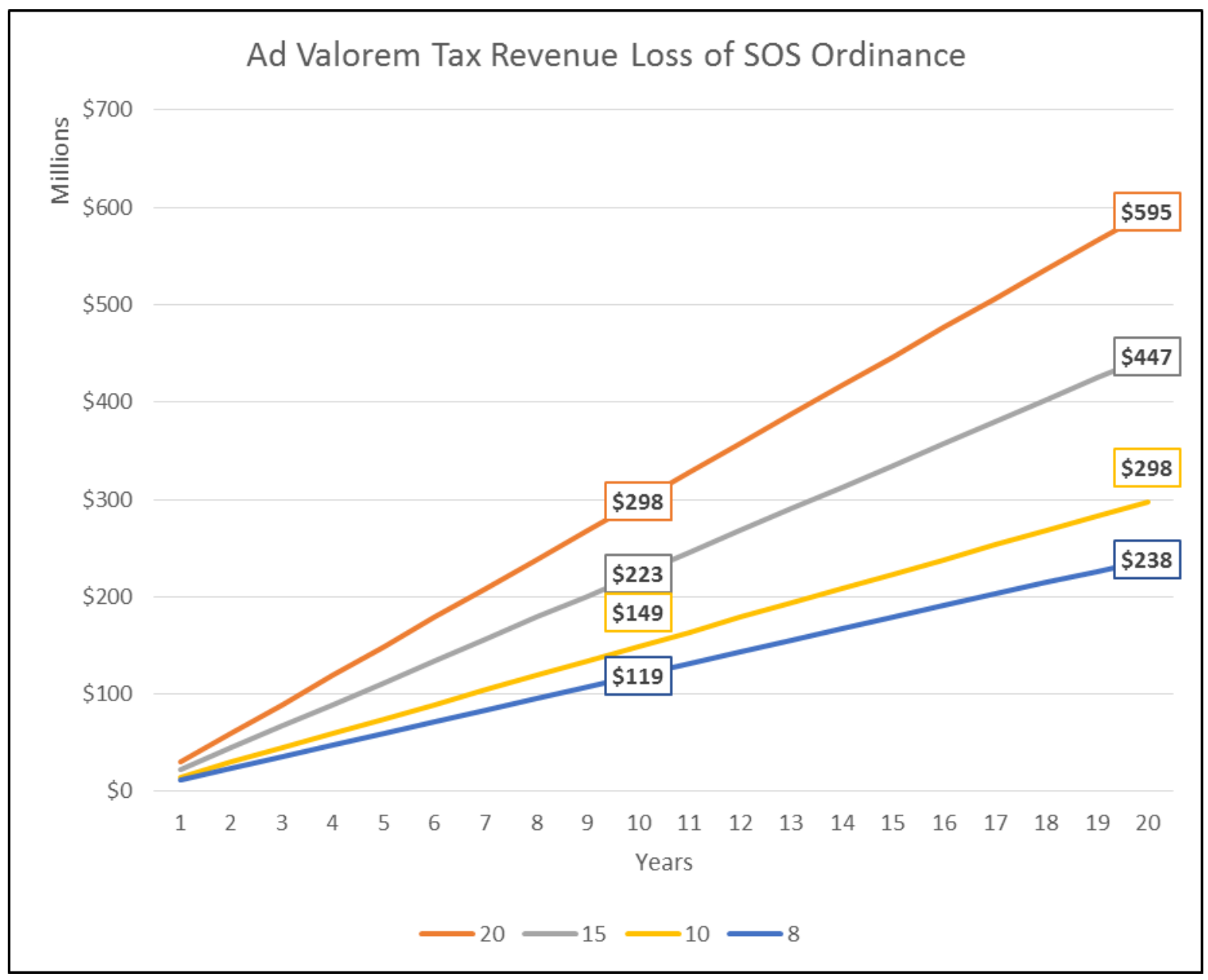

\section{Figure 6. Ad Valorem Tax Revenue Loss at Various Levels of Average Net Operating Income per Square Foot}

Figure 6 demonstrates the ad valorem tax revenue loss at varying levels of average net operating income per square levels ranging from an average of $\$ 8$ per square foot to $\$ 20$ per square foot. The $\$ 20$ per square foot average net operating income in Figure 5 is a best case scenario however, it is important to consider a range of scenarios that includes the worst case of average net operating income of \$8 per square foot. The result of these calculations provides a range of ad valorem tax revenue loss from $\$ 238,000,000$ to 
$\$ 595,000,000$. Even the worst case scenario results in a

substantial ad valorem tax revenue loss over 20 years.

The community and city council supported sos and had every right to decide to choose that course. Sadly, the record shows that few Austinites fully realized the long term impact on tax revenue of this ordinance over a 20 year period. With today's technology, science could prove the effectiveness of the ordinance in protecting the springs and the community could have chosen the loss of ad valorem tax revenue as a reasonable price to pay for protection of the springs. The ordinance certainly has not helped the creeks and streams in the 15\% ordinance area. The water class I wrote and have taught for 7 years at St. Edward's University (CULF 3331 - Global Water Challenges) has been shocked each semester when the students test water drawn from the area creeks. The results have been consistent - the water contains unacceptable coliform bacteria levels from leaking sewage lines and other pollutant sources. Many people questioned then and still do today whether Barton Springs and its recharge zones were actually enhanced and protected by the ordinance. ${ }^{242}$ In fact, in an August 3,

${ }^{242}$ Mayor Thom Farrell of the City of Rollingwood, a city surrounded by Austin and potentially impacted by Austin's extra territorial jurisdiction, told me Rollingwood ran tests into their SOS boundaries by inserting dye into the underground Karst-type aquifer recharge locations. The dye did not eventually emerge in Barton Springs, but in Deep Eddy, a spring across the Colorado River. Other groups fought the ordinance to no avail. Since under Texas law guaranteeing the police power of municipalities, zoning ordinances and zoning overlays 


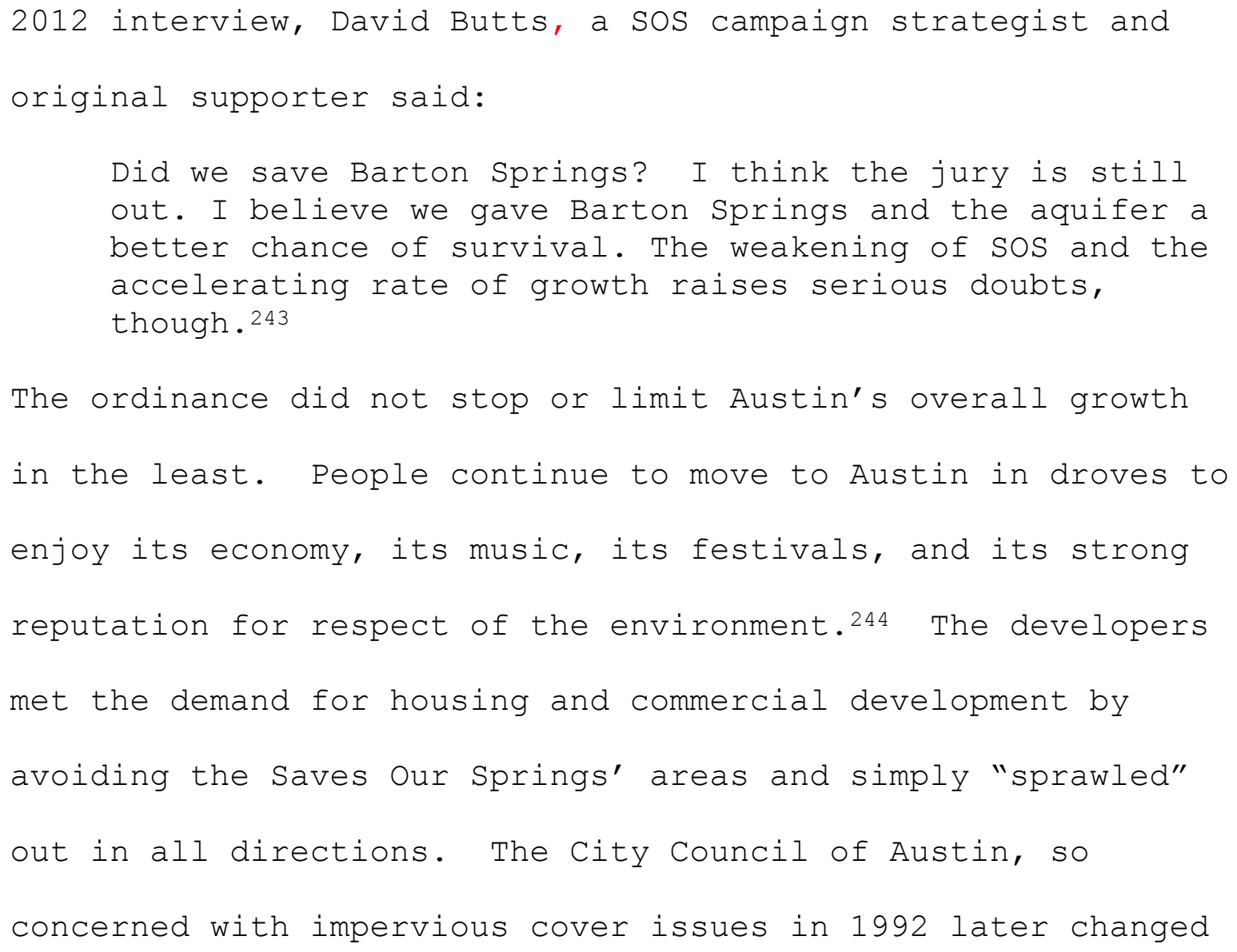

are not considered "takings" by government in which "just compensation" would be due affected landowners. According to UT Law School Researchers Thomas McGarity, Sanford Levinson, Douglas Laycock, and Jordan Steiker interviewed at the time of the ordinance's birth for the Texas Water Research Institute's October 1992 newsletter, "... the SOS Ordinance is not a taking because it allows single family homes and other projects to be developed."

243 "Memoirs of a Movement". The Austin Chronicle, August 3, 2012. His comments on the "weakening" are highly prejudicial. I can testify to the consequences on property I owned on SH 71 in Oak Hill. One property in the SOS zone, 6 acres, which was zoned commercial, due to the SOS impervious limitation, was not large enough to even develop a badly needed emergency clinic of only 4,000 square feet. For a scholarly analysis of the SOS movement in Austin see William Scott Swearingen, Jr.'s Environmental City: People, Place, Politics, and the Meaning of Modern Austin. Austin: University of Texas Press, 2010. Scott is a friend of mine and faculty colleague at St. Edward's University. Greg McLauchlan reviewed his book for the "American Journal of Sociology, Vol. 116, No. 5, March 2011. McLauchlan said of Scott's conclusions "...largely absent are metrics or data that would allow readers to judge Austin's success as an "environmental" city." Again, I offer in this study and my previous published article the first and only research into the ad valorem tax revenue consequences of the Save Our Springs Ordinance. For a discussion of urban sustainability see Steven A. Moore's Alternate Routes to the Sustainable City: Austin, Curitiba, and Frankfurt. Lanham: Lexington Books, 2007.

${ }^{244}$ Another unintended consequence of Austin's aggressive environmental positions is to actually have the opposite effect on population growth - it increased growth as much by reputation of a "special green" city. 
its mind and decided a marked increase in new development downtown was desirable.

In 2007, the city council, in order to increase downtown development, took a position in the exact opposite direction of impervious cover limitations by increasing the impervious cover allowable to $100 \%$ by creating a new downtown geographical area zoning category, "Downtown Multi-Use" or DMU zoning. ${ }^{245}$ To say the least, the elected leaders succeeded in directing huge volumes of growth downtown, ${ }^{246}$ but along with it came the thorny issue of gentrification ${ }^{247}$ of neartown neighborhoods, especially those just east of downtown, traditionally African American and Latino/Mexican neighborhoods. ${ }^{248}$ The city used re-zoning to expand downtown because it was less expensive for the city to tie new developments into existing storm and sanitary sewage, electricity trunk lines, and other already in-place

\footnotetext{
${ }^{245}$ Austin City Council C14-2015-0093 - November 12, 2015, "The DMU Zoning District allows 100\% impervious cover."

${ }^{246}$ Austin has had an explosion of multi-family high rise condominiums and apartment properties built downtown since the DMU zoning has been in place. Hotels, office buildings, retail - all accompany the millions of square feet of new development.

${ }^{247}$ Webster defines gentrification as "the process of renewal and rebuilding accompanying the influx of middle-class or affluent people into deteriorating areas that often displaces poorer residents." Many inner city neighborhoods in Austin would strongly argue their neighborhood was not "deteriorating" and I agree.

${ }^{248}$ See 2010 census of Austin, Texas.
} 
infrastructure. ${ }^{249}$ Millions of square feet of mostly high rise condominium units have been built and sold in downtown Austin in the past 8 years thanks in a large degree to the change in the opposite direction about impervious cover restrictions downtown taken by city leaders 25 years after the sos Ordinance.

Bunch's position during the time of the Save Our Springs debate was clear and exactly the opposite of his position in Brenham in 2012. Conservation then, at least in the proposed Sos area of Austin, would not be enough to protect the aquifer, hence the group's proposal to restrict growth. It was a very effective way to limit development, the sos group's basic goal. 250

Bunch and the sos Alliance are not alone in this local approach of using water as a weapon of social control. Sos ideas likely influenced another central Texas group to use water as a weapon to control growth. For several years, various environmental groups proposed that the Edwards Aquifer Authority (EAA) limit all impervious cover across their jurisdictional boundaries to less than 20\%; some even

\footnotetext{
${ }^{249}$ I served as Chairman of the Board of the Austin Board of Realtors in 2007. City officials and professionals such as architects and engineers made it clear to me this was a major reason for the new DMU zoning.

250 "The SOS Ordinance Turns 20". The Austin Chronicle, August 3, 2012. "... green activists who crafted the SOS ordinance to limit the amount of development allowed within the Edwards Aquifer recharge and contributing zones."
} 
to limit impervious to $15 \% .251$ The EAA is a special

groundwater regulatory district whose jurisdiction covers

8,800 square miles 252 or 5,632,000 acres of the Edward's

aquifer footprint in south central Texas. The EAA allocates

groundwater withdrawals, requires meters on irrigation wells

and registration of all wells including those classified as

commercial or as domestic/livestock. According to an

environmental group, the Greater Edwards Aquifer Alliance,

their "Edwards Aquifer Protection Plan" included this

exhibit, "Recommended Minimum Water Quality Regulations":

Impervious cover limitations are essential to preserve the natural quality, quantity, and timing of flow into streams and springs. We recommend an impervious cover limit of $10 \%$ of net site area in the recharge zone and $15 \%$ in the contributing zone. ${ }^{253}$

The vast majority of Texans agree that protecting groundwater sources in the state is desirable. However blanket limitations on growth and real estate development over 8,800 square miles without scientific support, thereby consciously ignoring the vast diversity of conditions in the aquifer recharge and contributing zones in the area, is unfair to

\footnotetext{
251 "Reforms for Aquifer Protection". Aquifer Guardians in Urban Areas, San Antonio, Texas, August 7, 2005.

${ }^{252}$ www.edwardsaquifer.org. See Aquifer Education tab.

253 "Edwards Aquifer Protection Plan". The Greater Edwards Aquifer Alliance. Exhibit B. No date was shown on the document, but it is currently an active proposal. See aquiferguardians.org. Basically all of the 8,800 square miles of EAA jurisdiction are recharge or contributing zones.
} 
existing landowners and unwise as public policy. A blanket approach such as this would have dramatic unintended consequences for generations of future Texans, negatively impacting public school education's general revenue for the mostly rural population living inside the EAA boundaries. Yet, no one seems to take the tax-based impact seriously, not even the impacted public school superintendents.

Bunch's unsupported misrepresentations at the Lone Star Water Forum, the SOS Ordinance in Austin, and the proposals of the groups attempting to protect the Edwards Aquifer, are examples of patterns of pressure through which society attempts to maintain social order and cohesion. The groups supporting the impervious cover limitations use persuasion through the normal political process in Texas and it is their right to do so.

However, they also used shame, coercion, force and restraint in the promotion of their position. Their overall message of shame is obviously clear as an underlying theme of all their rhetoric; shame on the development of "pristine" nature by "evil corporate developers."

This message of "shame on you" was directed to Jim Bob Moffett's Freeport-McMoRan Corporation in its proposed Barton Creek area 4,000 acre development in 1990. Beginning that year and lasting for the years after the sos ordinance passed 
into law, Moffett was personally vilified in the local, state, and national press and attacked continuously due to his development plans for the land his corporation owned.254 The groups such as the sos Alliance and other citizens against the Barton Creek proposal used coercion and force as evidenced no more clearly than the day they trapped Moffett in a construction trailer on site. In the summer of 1992, the protesters physically tried to push the trailer off its foundation with Moffett inside.255 A comment typical of the attitude of many in the group supporting the sos ordinance then was made by Nicolo Festa, a neighbor in the area: "Let Moffett and his like go peddle their poisoned wares elsewhere."256 The site plan of the proposed 4,000 acre Barton Creek Estates development included a golf course, clubhouse, and single family residential building sites of low-density (under 3 homes per acre) and the homes were planned to be offered for sale in the upper ranges of market prices at the time. Is it true and fair to characterize a golf course accompanying a low-density single family home development as "poisoned wares"?

\footnotetext{
254 "The SOS Ordinance Turns 20". The Austin Chronicle, August 3, 2012. A June 7, 1990 all-night City Council meeting in Austin included 900 people speaking against the development.

${ }^{255}$ I personally witnessed the protest and physical attack on the construction trailer.

${ }^{256}$ Jenny Rice. Distant Publics: Rhetoric and the Subject of Development Crisis. (Pittsburgh: University of Pittsburgh Press, 2012) 76.
} 
Water as a weapon of "deceptive" social control is exemplified by the sos Ordinance, a weapon based not upon on credible science but on speculation, emotion, and stereotypical attitudes. When one of the sos' own original spokespersons some 20 years later declares "... the jury's still out" on whether his group saved Barton Springs, the true tactic of the SOS supporters was made clear - to use water as a weapon of social control to stop population growth. According to Robert F. Williams, Distinguished Professor of Law at Rutgers University Law School:

The motives of each of the actors in the Barton Springs affair are easily explained by the rapid growth Austin has undergone in the last ten years. Until the 1990's, Austin was a quiet town of approximately 500,000 citizens. The town's most prominent characteristics were its status as the home of the state capitol and the University of Texas. Many of the residents of Austin lived there because of the city's tranquil setting. The high technology boom of the 1990's changed Austin significantly. Austin became home to a large number of software companies, one of which was Dell Computer, and consequently saw a staggering amount of growth within a very short time. The original residents of Austin responded to the rapid growth negatively, and sought to obstruct it. City regulations became increasingly complex, reflecting an attitude among many in local government that "no development is good development."257

Professor Williams from far away Camden, New Jersey, only eight short years after the sos Ordinance was passed in

${ }^{257}$ Robert F. Williams. DEVELOPMENT IN STATE CONSTITUTIONAL LAW: 2000. Rutgers Law Journal, Summer, 2001, 32 Rutgers L. J. 1499-1500. 
Austin, clearly supports the position of this study: that water was used as a weapon of social control in Austin to "obstruct" growth.

An even more direct use of water as a weapon of social control which I refer to as "destructive" social control has happened in Israel for decades and most recently in India.

\section{"Destructive" Social Control in Israel and India}

Perhaps the ultimate example of water policy as a means of "destructive" social control is the well-publicized longterm Israeli-Palestinian argument over access to water. More recently in February 2016, a major crisis in water occurred in India when the Jats closed the main canal providing water to Delhi putting ten million people without water resulting in riots and many deaths. A look at the situation in these countries exemplifies the concept of "destructive" social control. Please keep in mind that the intent of this book is not to propose a solution to these multi-faceted problems nor is it attempt to determine the true motivations by the parties involved. The message here is simple: water is the ultimate weapon of social control.

\section{Long Term Israeli-Palestinian Water Policy}

Over the past twenty years, volumes have been written about the hydropolitics between Israel and Palestine. The control of Palestinian water supplies by Israel is a long- 
term example of "destructive" social control. Recall that the concise definition of hydropolitics I mentioned earlier in this book is "the authoritative allocation of values in society with respect to water." The authoritative allocation of water can be accomplished by the due process of governments or their agencies or in the case of Israel and Palestine, by national policy determined not by diplomacy but by military control or force. It is common and accepted knowledge worldwide that Israel holds control and power over Palestinian access to water in the Gaza Strip and even more so in the West Bank, especially since the 1967 Israeli occupation. Yet an unbiased look at the facts show that both

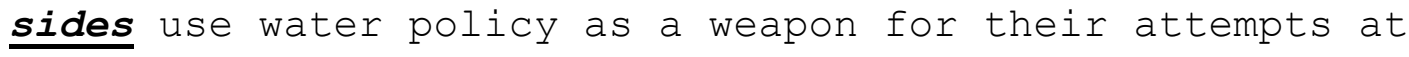
social control. The debate between them is so polarized it is difficult to discern the truth of the situation. Faced with this challenge, an eyewitness report proves helpful. To attempt to determine a better view of the actual water relationship between Israel and Palestine, Amani Mousa, 258 a visiting West Bank Palestinian graduate student attending st. Edward's University in Austin, was interviewed. During the interview, Amani did not display any vindictive or angry attitude about the water situation with the Israelis at

\footnotetext{
${ }^{258}$ Live interview between the author and Amani Mousa on Sunday, November 8, 2015 in Austin, Texas.
} 
her home in the West Bank. She approaches the difficulties with water at home with disappointment of course, but with an admirable degree of acceptance as well. She realizes fully that she lives in an occupied land. Her only real frustration was with the process it takes to accomplish routine tasks at home without oddly occurring delays or obstacles placed in the way of what we in America would consider everyday normal life. For example, Amani said there are reasons to enter into Jerusalem from time to time and sometimes she waits hours at one gate only to then enter and arrive at another gate that has closed for the day without any notice to the earlier gatekeepers.259 Each day seems to offer a new challenge to living a "normal" life. Her passport lists her as a person without any nationality, causing her delays and headaches in travel.

Amani has an inquiring mind, is dedicated to her education, and has exhibited servant leadership as a student in Austin's st. Edward's University community. Amani is a peer-reviewed academically published author writing in both her native language and in English. Her comments in the interview were credible and unbiased. Overall as to water availability, she anticipates little will change at her home

\footnotetext{
${ }^{259}$ Ibid.
} 
and that her family will continue to have limited access to water. 260

Amani said her neighbors are all but entirely dependent on Israel's Mekorot 261 national water company for their daily water. There is little reliability for water deliveries some days at home she had access to water, others none at all. In fact, sometimes water was not available to her for several days. She said her father manages the extended family cistern which he tries to keep full when he can when the Israeli provider makes water available. (Interestingly, her family shares the cistern with her uncles and cousins without a written agreement as to use or amount used. All users agree to follow her father as allocator of water to the families without dispute.) Responding to a question about new water wells as a potential source of water, Amani said permits to dig any water wells had to be obtained from both Palestinian and Israeli authorities. She indicated that it was almost impossible to gain both regulatory group's approval, a comment supported strongly by this author's research from other sources. Asked about the quality of the water her

\footnotetext{
${ }^{260}$ Ibid.

${ }^{261}$ Per Wikipedia, Mekorot (Hebrew: מקורות, lit. "Sources") is the national water company of Israel and the country's top agency for water management.[1] Founded in 1937, it supplies Israel with 90\% of its drinking water and operates a cross-country water supply network known as the National Water Carrier. Mekorot and its subsidiaries have partnered with numerous countries around the world in areas including desalination and water management.
} 
family receives when they do get it, Amani said it varies; at times the water appears clean and pure and at other times it is a brownish liquid that they drink and use anyway. Her father pays the water bills so she was not sure of the cost and has no frame of reference for the price except that her father considers the price too high, yet he rarely complains. Amani's family lands were confiscated by the Israelis without compensation years ago - they had been farmers for as long as anyone could remember in her family history, farming their family owned lands. ${ }^{262}$ Amani's comments are congruent with the literature of the Palestinians and many third party outside observers. Her comments were in diametric opposition to the water literature of the Israelis; the Israeli side as a whole praises and promotes the fine job Israel has done in providing pure water to the Palestinians reliably, on time, and in adequate quantities.

To seek the Israeli viewpoint from everyday life, a focus group was held with three PhD candidates in Engineering at the University of Texas at Austin. All three students are of the Jewish faith, two were born in Israel, the other, while born in Texas, had traveled extensively in Israel and studied the water situation there for years. Yuval Edrey was

\footnotetext{
${ }^{262}$ Ibid.
} 
born in Haifa which is still his home. Yael Glazer was born in Israel but only lived there until she was three years old. Both of their perspectives help illuminate the Israeli side of the issue of water.

All three students made it clear that fresh water is above all else, precious to all Israelis. From elementary school onwards, all Israeli students are taught why water is important, how to conserve water, and to always remember water is to be respected and shared in common. All water is public property in Israel. Children are taught simple ideas about conservation such as, during the wait time for shower water to warm up, to place a bucket under the shower head to save the cold water for other use. They are taught not to allow the faucet to run while they are brushing their teeth. According to Yael, they are taught by cartoons that show not only techniques, but the one who wastes water is portrayed as a "villain" with a long curly moustache and an evil look on his face. Even though with desalination today most of Israel has no water shortage, since water conservation is a normal way of life, the preciousness of the water is still dear to everyone's heart.

Some of Amani's comments that can summed up as an expression of "water insecurity" were shared with the group. "Water security" is, according to the UN Water the United 
Nations inter-agency mechanism on all freshwater related issues, including sanitation,

... defined as the capacity of a population to safeguard sustainable access to adequate quantities of acceptable quality water for sustaining livelihoods, human wellbeing, and socio-economic development, for ensuring protection against water-borne pollution and waterrelated disasters, and for preserving ecosystems in a climate of peace and political stability. ${ }^{263}$

Water insecurity would be the antithesis to this definition.

A key to understanding the reasons why the extreme viewpoints of some Israelis and Palestinians on water as a weapon of social control can be found in the very word "security". As explained by the Israeli focus group, until recently, especially from Yuval's viewpoint, daily life even in his home in Haifa was simply not "secure" - a life lived never knowing if (or when) another random violent event would happen in your very neighborhood. The feeling of the focus group was that as young people, just like Amani, all they wanted was peace and to live a normal life.

The opinion of the focus group was that the extreme factions in Israel would likely use and have used water as a weapon of "destructive" social control, but on the other hand, they suspect the extreme Palestinian political control groups would just as soon continue to have water security not

\footnotetext{
${ }^{263}$ http://www.unwater.org/topics/water-security/en/ .
} 
enter the normal lives of those living in the West Bank or Gaza and in this manner, these groups are equally as guilty of using water as a weapon of "destructive" social control. Any possibility of "due process" social control was discussed, even having a chance someday to enter into the relationship between Israelis and Palestinians. Yuval opined that Palestinians were given the opportunity to become Israeli citizens and gain access to "due process" of law but chose not to do so. Until violence is no longer a part of the relationship between Israelis and Palestinians, "diplomatic" social control as a solution simply will not have a chance. Their comments were very enlightening as to the inquiry about a planned effort by Israel to make daily life so miserable that the Palestinians would move away. The group said, sadly, there was no place for the Palestinians to go; no one wanted them. The group discussed that life in the West Bank and in Gaza for the Palestinians was like living in a "little prison;" very restricted and uncomfortable. One member of the focus group even offered an understanding of the willingness of young extremists to commit suicide for the Palestinian cause because the focus group member would likely consider it if they had to live in Gaza. The focus group was unable to offer any workable solution to the many problems, but did say they felt more secure in Israel today. Yuval had 
served his mandatory military tour before coming to the

United States; he expressed how difficult it was, and

discussed the arms and support the extremists in Palestine

get from other countries like Lebanon and Syria as one of his

frustrations with neighboring countries.

The consensus of the focus group was that the Israeli

water company exerts social control over their water supply

by pricing, but availability is no longer an issue. The group

felt that the lack of a reliable water source Amani and her

family faces may not only be blamed on Israeli policy or the

Israeli water company, but they speculated there was a

Palestinian group who acted as a "middleman" that could be

equally culpable as well. Their opinion was that politics

made the entire situation with water for the Palestinians

what it is today, not the physical availability of water

considering the new technologies.

\section{Views of the Stakeholders and Experts}

The geological containers of water in Israel and the

occupied Palestinian territories are not only shared between

them, but are also shared with Jordan. ${ }^{264}$ According to a

United States-based non-profit, The Water Resources Action

Project (WRAP) :

\footnotetext{
${ }^{264}$ The Jordan River is the main surface watercourse shared but there are also several shared aquifers as well. Israel claims ownership of the surface and groundwater much to the dismay of Palestine.
} 
The primary sources of water in Israel, West Bank, and Jordan are a combination of surface water rivers and seas, groundwater reservoirs, and desalinization plants. Surface water accounts for 30\% of Israel's supply, totaling 550 million m3/year (MCM/yr) [million cubic meters per year]. Major sources of surface water include the Sea of Galilee and the Jordan River. However, the Jordan River has become polluted and has lost 90\% of its normal flow (Belt). Israel also sits on a series of major aquifers, which yield 850 MCM/yr. Furthermore, Israel has initiated a major project to develop several large desalination plants with the capacity to supply approximately $500 \mathrm{MCM} / \mathrm{yr}$ by 2015.265

Adding to that is the undeniable fact that worldwide humans damage water not only with fertilizer and herbicide runoff from agribusiness activities, storm water runoff from streets and pavement, and industrial pollution, but also with human waste, commonly referred to as "sanitary"266 sewage. The disposal of human waste is a serious point of contention between Israel and Palestine.

Israel's technological achievements in water earn and deserve worldwide praise. The Israelis consider water precious, exhibiting a starkly different attitude to water than many or maybe even most Americans do. The Israelis have maximized the use of both surface and groundwater, making the "desert bloom" for decades. A new book written by Seth M. Siegel, Israel's Solution for a Water-starved World: Let

\footnotetext{
${ }^{265}$ WRAP. "A Comparative Study of Water Data Across Israel, West Bank and Jordan." December 2013. 266 "Sanitary" sewage - an English language oxymoron.
} 
There Be Water, is a fine source for the history of Israel's

water development from 1937 to 2015. In recent years

according to Siegel,

In about ten years, beginning shortly after the new century, Israel went from scarcity of water and fear of drought to abundance and independence from climate conditions. This dramatic change was made possible by the seventy years that preceded it in which a cadre of often brilliant engineers, scientists, and policy makers developed Israel's water-related expertise, technology, and infrastructure. 267

Israel's water programs succeed through the never ending pursuit of new ideas, use of up-to-date technologies, and establishment of water management and allocation policies that have enhanced Israeli citizens' access to water so successfully that Israel was able to declare itself, according to siegel, "water independent from weather" in October 2013.268 The Palestinian view is that the only people whose water resource was enhanced were the Israelis.

Does Israel use water as a weapon of social control over the Palestinians? Absolutely, but a fairer answer gleaned from review of the myriad of articles written about the subject over the past 20 years is that both the Israelis and Palestinians consider water to be one of their most potent

\footnotetext{
${ }^{267}$ Seth M. Siegel. Israel's Solution for a Water-starved World: Let There Be Water. (New York: St. Marten's Press, 2015) 235.

${ }^{268}$ Ibid. ix-x. So far I have been unable to find the person or organization or agency in Israel that specifically made this declaration.
} 
weapons in their attempts at social control. Israel holds the upper hand as far as the physical supply of water to Palestine at this time and has for decades. The two sides of the debate are diametrically opposed in their viewpoints of the water situation. Most of the arguments in this debate are conducted by truly credible experts of all disciplines from each side making it very difficult to determine the "whole truth, and nothing but the truth" in the Israeli-Palestinian water conflict.

Siegel, on the one hand, opines that, One major impediment to resolving water issues between Israel and the Palestinians is that - after many years the Palestinian Authority (PA) has decided to make use of water as a tool to reinforce political claims against Israel, rather than working with Israel to find pragmatic solutions to Palestinian water needs. ${ }^{269}$

Siegel thinks the rivalry between the Palestinian Authority, supposedly the governing body of the West Bank and Gaza Strip, and Hamas exacerbate the situation for all sides and may be a basic cause of the politicization of the water issue. 270 Siegel's views coincide with the opinions of the Israeli focus group mentioned above.

\footnotetext{
${ }^{269}$ Ibid. $175-176$.

${ }^{270}$ Ibid. Does Hamas' stance that Israel should not exist cause the PA to be confrontational with Israel over water? Do internal pressures between the PA and Hamas result in deliberate non-cooperation with Israel over water? Siegel asks very germane questions and opines that it is "a key area" of the PA's choice to not cooperate.
} 
The viewpoint of Professor Haim Gvirtzman of the Hebrew

of Jerusalem aligns with Siegel also. His executive summary

in a paper he wrote published by the Begin-Sadat Center for

Strategic studies represents an accurate summary of the basic

Israeli position on the water dispute:

Water shortages in the Palestinian Authority are the result of Palestinian policies that deliberately waste water and destroy the regional water ecology. The Palestinians refuse to develop their own significant underground water resources, build a seawater desalination plant, fix massive leakage from their municipal water pipes, build sewage treatment plants, irrigate land with treated sewage effluents or modern water-saving devices, or bill their own citizens for consumer water usage, leading to enormous waste. At the same time, they drill illegally into Israel's water resources, and send their sewage flowing into the valleys and streams of central Israel. In short, the Palestinian Authority is using water as a weapon against the State of Israel [emphasis added]. It is not interested in practical solutions to solve the Palestinian people's water shortages, but rather perpetuation of the shortages and the besmirching of Israel.271

Further in his report, Prof. Gvirtzman writes, "The Palestinians live in the shadow of the State of Israel, a world superpower in terms of water technologies. Consequently, the Palestinians enjoy a relative Garden of Eden [emphasis added]."272 Amani gave no indication

\footnotetext{
${ }^{271}$ Prof. Haimi Gvirtzman. "The Truth Behind the Palestinian Water Libels". BESA Center Perspectives Paper No. 238, February 24, 2014. Published by the Begin-Sadat Center for Strategic Studies and found at http://besacenter.org/perspectives-papers/truth-behind-palestinian-water-libels/ .

272 Ibid. 5.
} 
whatsoever that she would at all agree that the West Bank was a Garden of Eden due to Israel's fair water policies.

On the other hand, according to the Palestine Liberation Organization Negotiations Affairs Department (PLONAD) in direct disagreement with Siegel and Prof. Gvirtzman:

Since its 1967 occupation of the opt [occupied Palestinian territories], Israel has completely controlled our water resources and deprived us of access to a sufficient share of water, in violation of international law. Instead, Israel has used our water resources for its illegal settlements and its own population, forcing our communities to purchase water from Israeli companies at high commercial prices. ${ }^{273}$

The PLONAD claims the Israelis use 86\% of the available fresh water resources and keep the Palestinians from developing water resources in their own territories which results in only 60 liters per capita per day for a Palestinian, well under the 100 liters per capita per day recommended by the World Health Organization. ${ }^{274}$ Keep in mind that Israel occupies the Palestinian territories, and as occupiers, have all the power.

According to Mark Zeitoun of the University of East Anglia in his book Power and Water in the Middle East: The Hidden Politics of the Palestinian-Israel Water Conflict,

\footnotetext{
${ }^{273}$ http://nad-plo.org/etemplate.php?id=179\&more=1\#1.

${ }^{274}$ Ibid.
} 
power is the key to control of water between the parties. Of

Israeli control, Zeitoun concludes:

... while their [Israel's] control was contested in the decades following 1948, it was essentially beyond contention after 1967. It evolved following the 1995 Oslo II Agreement into a pervasive and hegemonic form that endures today, with distinct forms of power enabling each stage in the evolution of Israel's dominance. ${ }^{275}$

Zeitoun's and PLONAD's opinions do coincide exactly with Amani's eyewitness experience at her home in the West Bank. One expert outsider's viewpoint helps further illuminate the situation.

Elisabeth Koek author of "Water for One People Only: Discriminatory Access and 'Water Apartheid' in the OPT' provides this opinion:

Since 1967, Isreal has exerted considerable military and political efforts, including the establishment of settlements, to illegally exercise sovereign rights over Palestinian water resources... This integration was significantly advanced in 1982 by the transfer of ownership of Palestinian water infrastructure in the West Bank to Israel's national water company 'Mekorot' which has forced Palestinians to rely on the company to meet their annual water needs... 'Mekorot' routinely reduces Palestinian supply - sometimes by as much as 50 per cent - during the summer months in order to meet consumption needs in the [Israeli] settlements. ${ }^{276}$

\footnotetext{
${ }^{275}$ Mark Zeitoun. Power and Water in the Middle East: The Hidden Politics of the Palestinian-Israel Water Conflict. (London: I.B. Tauris \& Co Ltd, 2012). 2.

${ }^{276}$ Elisabeth Koek. "Water for One People Only: Discriminatory Access and 'Water Apartheid' in the OPT". (Ramallah - West Bank - Palestine: Al-Haq) 2013. 16-17. Elisabeth Koek is a Legal Researcher with Al-Haq and holds an LLM in Public International Law from King's College London and an LLM in Corporate Law from the University of Leiden.
} 
Ms. Koek's paper supports Amani's eyewitness report to me as well.

As to the future of the conflict, Koek sees hope for a fair conclusion only if the parties follow international legal norms since Israel will continue to dominate Palestine at the negotiating table. ${ }^{277}$ Zeitoun sums up his book with the opinion that the only hope for Palestinians, especially in the West Bank, is to rely on privately owned desalination units for reliable water. Yet, how can any Palestinian owned company find financing for the project, assuming it could gain the needed permits to build and operate a desalination plant? Equally as difficult as finding financing would be thought not impossible, this question arises. Could the Palestinian people afford the cost of the infrastructure and the ongoing operation and maintenance of a desalination system? They would face the same problem as the Israelis in that as important as environmental sustainability is to any new water system, especially a desalination plant with its headaches of disposing of the briny by product of filtering out salts, a new water system must be financially sustainable as well. The users of the water system must be able to pay for installation, maintenance, and operation of the system.

${ }^{277}$ Ibid. 20. 
Zeitoun's dire prediction is that the Palestinian agricultural sector will "dry up slowly, as whatever good water remaining is devoted to the cities. The intensity of the water conflict will increase along with the inequity... ."278 The power imbalance will probably remain in favor of Israel.

As a certified and experienced mediator in Texas real estate and family law disputes for over 25 years, it is my opinion that unless the power imbalance between the Israelis and the Palestinians is somehow mitigated, a mediated settlement (any treaty is basically a mediated or negotiated settlement, a settlement in which the disputants own and make the decisions) is all but impossible to reach. Since there is no applicable and effective supra-legal authority other than that of Israel with jurisdiction over the dispute, unless the parties agree and appoint an outside authority that has the courage, power, and will to enforce any such agreement, it appears that the parties are hopelessly deadlocked. Yet with the many publicized predictions that the Palestinian population will grow at a faster rate than the Israeli population, a serious and terrible collision filled with more

\footnotetext{
${ }^{278}$ Zeitoun. 164.
} 


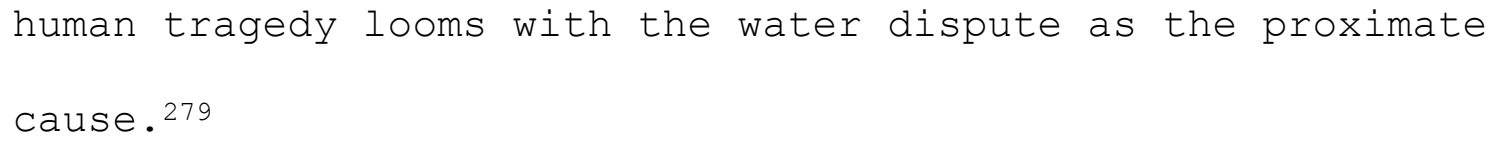

\title{
A Recent Event in India
}

\author{
Recently, a new example of "destructive" social control \\ using water as the weapon occurred in India, in and around \\ the city of Delhi. Delhi - whose current population in 2016 \\ is $18,686,902^{280}$ - is the fifth most populous city in the \\ world. Almost 60\% of the water supply for Delhi is drawn \\ from a surface water canal, the Munak, diverting water from \\ the Yamuna River. According to several news reports, on the \\ weekend of February 13th, a group of local upstreamers, known \\ as the Jats, a rural caste of northern India and Pakistan, \\ closed the sluice gate to stop water flow into the Munak \\ canal. In addition, they deliberately damaged a portion of
}

\begin{abstract}
${ }^{279} \mathrm{http}: / / w w w . i b t i m e s . c o . u k / w i l l-p a l e s t i n i a n s-o u t n u m b e r-i s r a e l i-j e w s-b y-2016-1481628$. Quoting from this article, "Professor Arnon Soffer from the geography department at the University of Haifa told the Jerusalem Post that 'today the percentage of Jews is 52\% and in 2024 it will be just 48\%'. Another academic, Professor Sergio DellaPergola of Hebrew University, said that 'the unquestionably documented fact is that the Arab population in our area is growing and will continue to grow for several years at a pace faster than the Jewish population'. In 2011, DellaPergola argued that the Jewish population would no longer be a majority around 2015." Earlier in the article, the authors opined, "The worst nightmare for Zionists and nationalists - that of an Israeli state where an ethnic minority rules over a majority, raising echoes of Apartheid-like system - seems to be approaching at an unrelenting pace." Even the demographics are in dispute as other sources disagree as to the rate of growth. Even if the rate of population growth is as one-sided in favor of the Palestinians as some claim, by 2050 I find no projection that does not keep the Israelis in at least the majority even though the gap would be closed to 55\% Israeli and 45\% Palestinian. "Proximate cause" is defined by the State Bar of Texas as: 1 . A proximate cause is a substantial factor, that [in a natural and continuous sequence,] brings about an event and without which the event would not have occurred; and 2. A proximate cause is foreseeable. "Foreseeable" means that a person using ordinary care would have reasonably anticipated that his acts or failure to act would have caused the event or some similar event. There may be more than one proximate cause of an event.
\end{abstract}

${ }^{280} \mathrm{http}: / /$ www.indiaonlinepages.com/population/delhi-population.html 
the canal itself.281 This action caused over 10,000,000 people in Delhi to lose access to water. In the aftermath of the resulting riots, nineteen (19) people lost their lives.282 With the deaths and rioting, the Jats' actions clearly demonstrate their use of water as a weapon of "destructive" social control; people lost their lives, and the lives of 10,000,000 people in Delhi were disrupted. Among the many reasons for the drastic action of the Jats, Delhi's geography and water resources coupled with the caste system still present in Indian politics are the most significant. Delhi's water resources come from the upper Yamuna River via the Munak Canal, 60\%, from the city's ancient appurtenance to the Yamuna River now badly polluted, 12\%, and the balance of which comes from groundwater. In centuries past, a now-polluted 13th century water storage tank, the Hauz Khas, or "royal lake or tank", which was at one time 123.6 acres in size, also contributed to Delhi's water supply. Hauz Khas was dug in order to catch stormwater runoff during the annual monsoons. As Delhi grew in the 1960s and 1970s, development moved westward away from the city's original adjacency to the Yamuna River. The Munak Canal stemmed from

\footnotetext{
${ }^{281} \mathrm{http}: / / \mathrm{www} . b b c . c o m / n e w s /$ world/asia/india . The photographs show massive damage to a portion of the concrete-lined section of the canal.

${ }^{282}$ Different news reports proclaimed sixteen (16) people were killed in the riots.
} 


\begin{abstract}
a 1996 agreement with the Haryana. The canal construction
project began in 2003, at first designed as only dirt-

bottomed. Later, the canal was lined with concrete due to seepage losses that some claimed to be up to 80 million

gallons per day. ${ }^{283}$ For over a decade, the states of Delhi

and Haryana have disputed the amount of flow Haryana

committed to provide Delhi in the original 1996 agreement.

Notwithstanding the ongoing dispute over flow, the Jats of

Haryana used water as a weapon to enact their anger over new

job caste rulings by the Indian central government.

The Jat is a rural caste of four million people in

Pakistan; the Jat in India include six million people.284 Some

of the Jats live in the once-Indian state of Punjab, the area

aforementioned in this book of the Indus River dispute of

1948-1960 and beyond. The Jats came into existence as a

political group in the $1^{\text {th }}$ century and established a military

kingdom in Punjab and its surrounds. Haryana's Jats are a
\end{abstract}

\footnotetext{
${ }^{283}$ https://www.kent.co.in/pdf/news/Annexure-1.pdf. Also, A similar condition occurred in the United States in the 1930's era All America Canal, the lifeblood for Imperial Valley farming in Southern California. In a 1944 treaty agreement with Mexico, the shared waters of the Colorado River fed the canal which began as a dirtbottomed canal. Seepage losses up to 67,000 acre-feet of water per year caused the United States to line 23 miles of the canal. The unintended consequences of this seemingly proper conservation project was to eliminate much of the seepage into the Mexi-Cali Aquifer that Mexican farmers relied upon for over 60 years. The United States always provided the 1.5 million acre-feet of water to Mexico per the treaty, hence the seepage was over and above the agreed upon amount to Mexico, hence the United States opined they had every right to line the canal no matter the consequence to the MexiCali farmers. The United States did not agree or disagree, but passed on the lawsuit under a lack of jurisdiction ruling, a ruling clearly that stated treaties and only treaties ruled in disputes among nations.

${ }^{284}$ http://www.cnn.com/2016/02/22/asia/india-unrest-water-crisis/
} 
"rural but relatively well-off caste"285 What is the caste system? According to Cable News Network,

For centuries, India's complex caste system has dictated a Hindu's lot in life, elevating some to positions as priests and labeling others as "untouchables." But caste discrimination was legally abolished in India's 1949 constitution, and the state later introduced a national quota system of government jobs and a university system as a kind of affirmative action for former lower caste. By 1990, 49\% of quota-related jobs and admissions had been set aside for people from tribes and lower social groups. ${ }^{286}$

The Jats in Haryana are upset over job quotas that do not recognize their caste as "economically disadvantaged" which they claim denies them access to many jobs. Since February 2016 negotiations have been underway to discover a remedy for the Jats' concerns.

The violent actions of the Jats in closing the canal and other protests such as blocking highways and railroad tracks are a prime example of "destructive" social control. Rather than rely upon the "due process" type of social control via the Indian Parliament, the Jats chose to use water as a weapon to promote their political agenda over job subsidies. Their use of water as a weapon gained immediate, almost instantaneous reactions; their "voice" in politics was heard

\footnotetext{
${ }^{285}$ Ibid.

${ }^{286}$ Ibid.
} 
within a few hours by ten million residents of Delhi. The issue was not about water or water rights at all; there was no argument about the long term agreement to divert water into the canal from their area. But the Jats used the most effective weapon at hand, the blocking of the major source of water to one of the largest cities on the globe.

The Israelis' control over the water supply of the Palestinian territories and the recent Jat "rebellion" demonstrate the power of water as a weapon of "destructive" social control. These examples hopefully will not be noticed by other powerful groups desiring social control over some other group. The dire predictions daily in worldwide news reports and scientific studies foretell disasters in nature's allocation of water due to climate change; the displacement of millions could result. As water resources become more stressed worldwide, it is doubtless but unfortunate that some groups will use water as their most immediate weapon of social control.

The third hypothesis, that the three pillars of society can be controlled by promulgating formal and informal water policies as weapons to control dissident behavior or to protest other government policies proves true as well. From the "deceptive" social control examples as outlined here that have occurred in Austin, Texas, to the "destructive" social 
control of Israelis over Palestinian water and the Jats

protest over unrelated public policy decisions, indicate that few more powerful and ultimate weapons of social control can be contemplated than that of public water policies. 


\section{Chapter Seven \\ Conclusion}

Defining social control briefly as the study of patterns of pressure through which society maintains order and cohesion, water proves to be one of the most effective, and possibly dastardly, weapons of social control worldwide. From Austin, Texas to Israel to New Delhi, water policy used as an emotional tool to accomplish other veiled agendas or direct actions are quite often the ultimate weapon to control societal behavior. At times, the emotional power of the issue creates unrealized basic value conflicts as illustrated in Austin's SOS Ordinance. No reasonably thinking person wants water to be short in quantity, bad in quality, or its marvelous attributes such as natural springs, creeks, and rivers to be contaminated by human growth or activity. However, emotions must be eliminated and hidden agendas must be made transparent and forthrightly debated so as to avoid unintended terrible consequences. Deliberate efforts by any dominant group to suppress a people, using water policy as a weapon, are not only inhumane but in the long term, likely detrimental to the dominant society - if in no other way than 
to earn them a reputation worldwide as unfair and even despicable in the eyes of the reasonably thinking and behaving world. In a globalized economy, interconnected today and apparently in our foreseeable future as never before in history, no nation can hope to thrive or maybe even survive with that kind of reputation.

Public water policies are absolutely the ultimate weapons of social control. Public water policies absolutely form the foundation for the three pillars of any society, the environment, the economy, and human relationships. 


\section{Bibliography}

Primary Sources

Arricivita, Juan Domingo. Tr. Hammond, George P. and Rey, Agapito. Cronica serfica y apostolica del colegio de propaganda fide de la Santa Cruz de Querétaro (Apolistic Chronicle of Juan Domingo Arricivita: The Franciscan Mission Frontier in the Eighteenth Century in Arizona, Texas, and the Californias). Berkeley: Academy of American Franciscan History, 1992 and 1996. (Original—Mexico: Don Felipe de Zuniga y Ontiveros, 1792.)

Bexar Archives Translations at the Center for American History. The University of Texas at Austin.

Bexar County Appraisal District. San Antonio, Texas.

Bexar County Real Property Records and Archived Records. County Clerk. San Antonio, Texas.

Bexar County District Clerk Archives. Court Journals, Indices, and Archived Pleadings. San Antonio, Texas.

Black, Henry Campbell. Black's Law Dictionary Sixth Edition, (Saint Paul: West Publishing Company, 1990) 302.

Brackenridge Book Collection. The University of the Incarnate Word Library Special Collections. San Antonio, Texas.

Brackenridge (John Thomas) and (George W.) Papers. Center for American History. The University of Texas at Austin. Austin, Texas.

Brackenridge (John Thomas) Papers. The State of Texas Archives. Austin, Texas.

The Chamber of Commerce of San Antonio, Texas.

City Map of San Antonio. Southwell Map Company, 1946. 
The City of San Antonio, Archives of City Council Minutes, City Clerk, Leticia M. Vacek. San Antonio, Texas.

Corner, William, Editor. San Antonio de Baxar. San Antonio: Bainbridge \& Corner, 1890.

Cortina Letters, ed. tr. Jerry D. Thompson. Juan Cortina and the Texas-Mexico Frontier, 1859-1877. E1 Paso: Texas Western Press, 1994.

Cutter, Donald C., ed., tr. Hugo Oconnor Informe sobre los Presidios del Norte de Nueva Espana dado alVcry Marques de Croix 1777 (named by translator Hugo O'Conor's Report to Teodoro de Croix, July 22, 1777). Dallas: Southern Methodist University Press, 1994.

Davis, Chester B. . Report Upon A Valuation of the Plant of the Water Works Company of San Antonio, Texas. San Antonio: Private Press, June, 1902.

Edrey, Yuval. Israeli. Live interview June 7, 2016. Austin Club, Austin, Texas.

European Union.

"Environment: Commission urges Spain to adopt river basin management plans."

Brussels, 2011. http://ec.europa.eu/. Accessed 8/22/15.

- "Spain: Commission pursues legal action over breaches in environmental law."

Brussels, 2008. http://ec.europa.eu/. Accessed 8/22/15.

--------- "Commission refers Spain to Court over illegal landfills.” Brussels. Press release.

16 July, 2015. http://ec.europa.eu/. Accessed 8/22/15.

--------- "Environment: commission takes Spain to Court over urban waste water and river basin plans.” Brussels. Press release. 16 June, 2015. http://ec.europa.eu/. Accessed $8 / 22 / 15$.

“- Infringements: Frequently Asked Questions.” Strasbourg. 17 January 2012. http://ec.europa.eu/. Accessed 8/22/15. 
Official Journal of the European Union. "Directive 2008/98/EC of the European

Parliament and of the Council of 19 November 2008 on waste and repealing certain

Directives. 22.11.2008. L 312/3.

Official Journal of the European Communities. "Council Directive of 21 May 1991

concerning urban waste water treatment (91/27/EEC).

Erwin, Frank C., Jr. . Letter to the Members of the Board of Regents, July 10, 1973. From the University of Texas Board of Regents. Austin, Texas.

Espinosa, Fray Felix de Espinosa, O.F.M. . Cronica de los Colegios de Propaganda Fide de la Nueva Espana. Mexico: 1746.

Glazer, Yael. Israeli. Live interview June 7, 2016. Austin Club, Austin, Texas.

Guadalupe County District Clerk Archives. Court Journals, Indices, and Archived Pleadings. Seguin, Texas.

Herff, Peter Ferdinand, M.D., ed. Laura L. Barber. The Doctors Herff: A Three Generation Memoir. San Antonio: Trinity University Press, 1973.

The Institute for Texan Culture Vertical Files and Library. The University of Texas. San Antonio, Texas.

Lacoste Papers. Center for American History. The University of Texas at Austin. Austin, Texas.

LaPrelle-Brackenridge Papers. Austin History Center. Austin, Texas.

Leutenegger, Fr. Benedict, tr. Instruccion para el Ministro de la Mision de la Purissima Concepcion de la Provincia de Texas, 1787 (Instruction for the Minister of the Mission Purissima Concepcion of the Province of Texas, 1787). San Antonio: Our Lady of the Lake University, 1994. 
The San Jose Papers. Translated from original documents with unknown publisher, unbound, copied from the Institute of Texan Cultures, The University of Texas at San Antonio, loose files.

The Zacatecan Missionaries in Texas, 1716-1834. Texas Historical Survey Committee, Office of the State Archeologist Reports, Number 23. Austin: Office of the State Archeologist, 1973.

Inventory of the Mission San Antonio de Valero: 1772. Austin: Texas Historical Commission, 1977.

Journal of a Texas Missionary: The Diario Historico of Fr. Cosme Lozano Narvais, pen name Fr. Mariano Antonio de Vasconcelos. Transcript of the Spanish Original. Matson, Daniel S. and Fontana, Bernard L., Ed. Tr. . Father Bringas Reports to the King, Methods of Indoctrination on the Frontier of New Spain, 1796-97. Tucson: The University of Arizona Press, 1977.

McLean, Bert J. The Romance of San Antonio's Water Supply and Distribution. San Antonio: for the Water Company Shareholders, 1924.

Montoya, Juan de. Tr. Hammond, George P. and Rey, Agapito. New Mexico in 1602. Albuquerque: The Quivera Society, 1938.

Morrison, Andrew. San Antonio: Her Prosperity and Prospects. San Antonio: Private, 1897. Mousa, Amani. Palestinian, live interview Sunday, November 8, 2015 in Austin, Texas. Nixon, Pat Ireland, M.D. A Century of Medicine in San Antonio. San Antonio: Private, 1936.

Olmsted, Frederick Law. A Journey through Texas. Lincoln: The University of Nebraska Press, 2004.

Period Post Card and Map Collection of the Author. Austin: Private. 
Rodriquez, Jose Maria. Memoirs of Early Texas.

http://www.tamu.edu/ccbn/dewitt/rodmemoirs.htm accessed 6/21/2007

San Antonio National Bank. San Antonio and Your First National Bank Through the Years.

San Antonio: Claude Aniol \& Associates, 1953.

Sanborn Maps, July 1885 and 1892 San Antonio, Texas. New York: Sanborn Map and Publishing Co., 1885 and 1892.

Siete Partidas (Seven-Part Code) Partida 3, Titulo 28, Ley 1 (part 3, title 28, law 1).

State of Texas Laws of the State of Texas. Austin: The State of Texas, 1862.

State of Texas, Chapter 36, Texas Water Code.

Stillman, Chauncey Devereux. Charles Stillman. New York: Private, 1956.

Terrell (A.W.) Papers. Center for American History. The University of Texas at Austin. Austin, Texas.

Travis Central Appraisal District. Austin, Texas.

United States Geographical Survey Maps.

\section{Newspapers}

Dallas Morning News, 2006-2016

Fredericksburg Standard-Radio Post, 1986

Recorder-Times, 1983

San Antonio Daily Express, 1872-1896

San Antonio Evening Paper, 1850-1890

San Antonio Express, 1890-2007

San Antonio Herald, 1872-1890

The Semi-Weekly News, 1862-1880

Texas Democrat, 1849 
The New York Times 2006-2016

The Washington Post 2006-2016

The Chicago Tribune 2006-2016

The Wall Street Journal 2006-2016

\section{Special Research Sources:}

\section{Recent Reports on the Jat v. Delhi (City) water riots.}

http://www.indiaonlinepages.com/population/delhi-population.html .

https://www.kent.co.in/pdf/news/Annexure-1.pdf.

http://www.cnn.com/2016/02/22/asia/india-unrest-water-crisis/.

https://news.vice.com/contributor/vice-news-and-reuters .

http://www.hindustantimes.com/india/traffic-restored-on-nh-1-khattar-says-action-againstrioters-who-set-fire-to-shops/story-xoOMOlhubgE08gMMK53byI.html.

http://www.bbc.com/news/world/asia/india .

Bhattacharya, Suryatapa. “Why Is Delhi’s Water Supply So Vulnerable?” New York. Wall Street Journal. 22 February 2016.

\section{Court Cases}

Adjudication of Water Rights of the Lower Guadalupe River Segment, 730 S.W.2d 64, 67

(Tex. App.-Corpus Christi 1987, writ ref'd n.r.e.

City of Del Rio, Petitioner, vs. Clayton Sam Colt Hamilton Trust, by and through its

Trustee, J. R. Hamilton, Respondent, 08-755.

Chronological Documents in the Texas Supreme Court Case File:

Petition for Review—Filed: 10/30/2008 [119 KB]

Response to Petition [1.14 MB] | Appendix [8.11 MB]—Filed: 02/05/2009

Amicus Brief—San Antonio Water System—Received: 02/19/2009 [625 KB] 
Amicus Brief-Mesa Water-Received: 02/27/2009 [910 KB]

Amended Reply to Response to Petition-Filed: 03/25/2009 [111 KB]

Amicus Brief-Texas Farm Bureau—Received: 03/25/2009 [87 KB]

Petitioner's Brief on the Merits-Filed: 05/27/2009 [2.28 MB]

Respondent's Brief on the Merits [213 KB] | Appendix [9.17 MB]—Filed:

$06 / 30 / 2009$

Amicus Brief-CRMWA-Received: 06/30/2009 [1.10 MB]

Amicus Brief — City of Amarillo—Received: 06/30/2009 [397 KB]

Reply Brief-Filed: 07/20/2009 [1.48 MB]

Amicus Brief—Stewart Title Guaranty Company_Received: 08/05/2009 [105 KB]

Petitioner's Response to Post-Briefing Article and Amicus Brief-Filed: 08/11/2009 [479 KB]

Amicus Brief—San Antonio Water System—Received: 08/12/2009 [561 KB]

Petitioner's Response to Amicus Brief-Filed: 08/20/2009

Court of Justice, European Commission.

Curia documents, statistics, pleadings, judgments. http://curia.europa.eu/juris/ .

Accessed daily/weekly from 01/02/2015 - 06/09/2016.

- "Notes for the Guidance of Counsel." Notes for the guidance of Counsel in written and oral proceedings before the Court of Justice of the European Communities, February, 2008. http://www.curia.europa.eu .

Edwards Aquifer Authority and The State Of Texas Petitioners, v. Burrell Day and Joel McDaniel, Respondents, 08-0964.

(For the February 24, 2010 ruling in full, visit www.supreme.courts.state.tx.us/historical/2012/feb/080964.pdf) 
Chronological Documents in the Texas Supreme Court Case File:

Day_Petition for Review 01/30/2009

State—Petition for Review—02/02/2009

EAA—Petition for Review— 02/02/2009

Amicus Brief—Medina County Irrigators Alliance — 03/03/2009

EAA—Response to Petition—03/04/2009

Amicus Brief—Angela Garcia—03/06/2009

Amicus Brief-City of Victoria-03/30/2009

Amended Amicus Brief—Medina County Irrigators Alliance—04/08/2009

Amicus Brief—Texas Farm Bureau—Received: 04/29/200 [0.99 MB]

Amicus Brief—HGSD—Received: 05/01/2009 [941 KB]

Day—Response to State's Petition—Filed: 05/05/2009 [875 KB]

Day—Response to EAA's Petition—Filed: 05/05/2009 [931 KB]

Amicus Brief-Texas and Southwestern Cattle Raisers Association—Received: 05/05/2009 [494 KB]

State—Response to Petition—Filed: 05/06/2009 [441 KB]

State—Reply in Support of Petition—Filed: 05/20/2009 [298 KB]

EAA — Reply to Response to Petition—Filed: 05/20/2009 [1.76 MB]

Amicus Brief-The Alliance of EAA Permit Holders—Filed: 06/08/2009 [221 KB]

Supplement to Amicus Brief—The Alliance of EAA Permit Holders—Received: 06/09/2009 [121 KB]

Supplement to Amicus Brief—-The Alliance of EAA Permit Holders-Received: 06/18/2009 [76.9 KB]

EAA—Petitioner's Brief on the Merits—Filed: 09/18/2009 [2.53 MB] 
State-Petitioner's Brief on the Merits-Filed: 09/18/2009 [1.47 MB]

Day_Petitioners' Brief on the Merits_Filed: 09/18/2009 [5.35 MB]

Amicus Brief_Canadian River Municipal Water Authority_Received: 10/27/2009 $[2.52 \mathrm{MB}]$

Day—Respondent's Brief to State's Brief—Filed: 10/30/2009 [931 KB]

Day_Respondent's Brief to EAA's Brief—Filed: 10/30/2009 [1.73 MB]

EAA-Respondent's Brief on the Merits-Filed: 11/02/200 [6.34 MB]

Joint Amicus Brief-Texas Farm Bureau \& Texas Cattle Feeders AssociationReceived: 11/02/2009 [1.14 MB]

State-Respondent's Brief on the Merits_Filed: 11/02/2009 [920 KB]

Amicus Letter-Texas Comptroller of Public Accounts—Received: 12/15/2009

$[1.72 \mathrm{MB}]$

EAA—Reply Brief—Filed: 12/17/2009 [1.10 MB]

State_Reply Brief_Filed: 12/17/2009 [1.53 MB]

Day_Reply Brief to State's Response Brief_Filed: 12/17/2009 [705 KB]

Day_Reply Brief to EAA's Response Brief_Filed: 12/17/2009 [3.32 MB]

Amicus Brief-Texas Wildlife Association-Received: 01/12/2010 [173 KB]

Amicus Brief-Angela Garcia-Received: 01/26/2010 [1.23 MB]

Amicus Brief-Harris-Galveston Subsidence District—Received: 02/01/2010 [213

$\mathrm{KB}]$

Amicus Brief-Mesa Water-Received: 02/10/2010 [127 KB]

Amicus Brief—Texas Landowners Council—Received: 02/12/2010 [211 KB]

Amicus Brief_Pacific Legal Foundation-Received: 02/12/2010 [135 KB]

Amicus Brief_Bragg-Received: 02/16/2010 [7.54 MB] 
Amicus Letter Brief — City of Amarillo—Received: 02/16/2010 [393 KB]

Amicus Letter Brief—City of El Paso—Received: 02/16/2010 [3.84 MB]

EAA—Petition for Writ of Mandamus—Filed: 03/05/2010 [176 KB]

Day—Response to Post-Submission Letter Brief—Filed: 03/18/2010 [18 KB]

Amicus Post-Submission Letter-Bragg—Received: 05/10/2010 [21 KB]

Amicus Letter Brief-Bragg—Received: 05/25/2010 [30 KB]

Post-Submission Amicus Brief-Texas Alliance of Groundwater Districts-

Received: 05/28/2010 [142 KB]

Amicus Letter-Duncan—Received: 06/03/2010 [74 KB]

State-Post-Submission Brief—Filed: 06/10/2010 [78 KB]

Day—Response to Amicus Brief—Filed: 06/10/2010 [233 KB]

Day—Response to Post-Submission Brief—Filed: 06/28/2010 [432 KB]

Amicus Letter-Texas Farm Bureau—Received: 07/09/2010

Edwards Aquifer Authority—Response to Amicus Letter, August 30, 2010

Amicus Curiae Brief- The Texas Farm Bureau, Texas Wildlife Association and

Texas and Southwestern Cattle Raisers Association, July 11, 2011

Amicus Curiae Brief of The City of San Antonio by and Through The San Antonio

Water System in Support of Petitioner San Antonio Water System,

November 3, 2011

Day/McDaniel Response to the Amicus Curiae Brief of The City of San Antonio by and Through The San Antonio Water System In Support of the Edwards Aquifer Authority, November 14, 2011

Edwards Aquifer Authority and The State of Texas Petitioners, v. Burrell Day and Joel McDaniel, Respondents Amended Day/McDaniel Response to the Amicus Curiae 
Brief of The City of San Antonio by and Through The San Antonio Water System In Support of the Edwards Aquifer Authority, December 20, 2011

Glenn and Jo Lynn Bragg, Petitioners v. Edwards Aquifer Authority and Gregory Ellis,

General Manager of the Edwards Aquifer Authority, Respondents, 01-0436.

Edwards Aquifer Authority v. Chemical Lime, Ltd., 06-0911

Petition for Review-Filed: 01/29/2006 [663 KB]

Petitioners' Brief on the Merits-Filed: 07/06/2007 [2.22 MB]

Petitioners' Reply Brief_Filed: 10/05/2007 [1 MB]

Amicus Brief_-State of Texas—Received: 12/27/2006 [132 KB]

Amicus Brief on the Merits-State of Texas-Received: 08/08/2007

Respondent's Brief on the Merits-Filed: 08/24/2007 [2 MB]

The Adjudication of Water Rights in the Medina River Watershed of the San Antonio River

Basin v Alamo National Bank Independent Executor, 645 S.W.2d 596; 1982 Tex

App. LEXIS 5610 (1982).

Barshop et al.v. Medina County Underground Water Conservation District et al., 95-0881 .

Bart Sipriano v Great Spring Waters of America, No. 98-0247, Supreme Court of Texas (1998-1999).

Charles C. Motl et al. v R.W. Boyd et al. 116 Tex. 82; 286 S.W. 458; 1926 Tex. LEXIS 96, Supreme Court of Texas (1926).

City of Aspermont v Rolling Plains Groundwater Conservation District, 2008 Tex. App.

LEXIS 3274, Court of Appeals of Texas, Eleventh District, Eastland (2008).

City of Del Rio v Clayton Sam Colt Hamilton Trust, Supreme Court of Texas Court Case

LEXIS 723 (2009). 
Court of Justice of the European Union. December 2010 edition.

http://curia.europa.eu/jcms/upload/docs/application/pdf/2012-05/cjue en.pdf.

Court of Justice. Luxembourg, January 1, 2015. “COURT OF JUSTICE OF THE

EUROPEAN UNION ANNUAL REPORT 2014 Synopsis of the work of the Court

of Justice, the General Court and the Civil Service Tribunal”. Luxembourg, 2015. www.curia.europa.eu.

Edwards Aquifer Authority v Burrel Day and Joel McDaniel. Court of Appeals of Texas, Fourth District, San Antonio. LEXIS 9777 (2008).

Friendswood Development Company, et al.v Smith-Southwest Industries, 576 S.W.2d 21;

1978 Tex. LEXIS 404; 22 Tex. Sup. J. 107; 5 A.L.R.4 ${ }^{\text {th }}$ 591; 62 Oil \& Gas Rep. 218;

9 ELR 20452, Supreme Court of Texas (1978).

Guitar Holding Company, L.P., Hudspeth County Underground Water Conservation

District NO.I v CL Machinery Company and Cimarron Agricultural, LTD. Court of Appeals of Texas, Eighth District, El Paso. LEXIS 7869 (2006).

Heofs v. Short, 273 S.W. 785 (Tex. 1925).

Hugh Coates, et al.v Charles Hall, 2007 U.S. Dist. LEXIS 26294, United States District

Court for the Western District of Texas, San Antonio Division (2007).

In Re the Contests of the City of Laredo, et al., To the Adjudication of Water Rights in the Middle Rio Grande Basin and Contributing Texas Tributaries, 675 S.W.2d 257; 1984 Tex. App. LEXIS 5687, Court of Appeals of Texas, Third District, Austin (1984).

InfoCuria - Case-law of the Court of Justice, List of results. http://curia.europa.eu/juris/documents . 
Lee, Thomas F. "Re: Glenn and JoLynn Bragg v Edwards Aquifer Authority; Cause No.

06-11-18170-CV in the 38 ${ }^{\text {th }}$ District Court of Medina County, Texas." (May 2010).

Lupe Alonzo, Jim Alonzo, Joe Alonzo and Valentino Alonzo v United States of America, 249

F.2d 189, United States Court of Appeals Tenth Circuit (1957).

Oscar C. Gordon v San Antonio Water System, 2007 Tex. App. LEXIS 1932, Court of Appeals of Texas, Fourth District, San Antonio (2007).

Pecos County Water Control and Improvement District No. 1 v Clayton W. Williams et al. Court of Civil Appeals of Texas, El Paso, LEXIS 2113 (1954).

San Antonio River Authority, Petitioner v. G. Garrett Lewis, et al., Respondents, No. !-8304, The Supreme Court of Texas, 363 S.W. 2d 444. Austin: The Supreme Court of Texas, 1962.

San Antonio River Authority v G. Garrett Lewis, 363 S.W.2d 444; 1962 Tex. LEXIS 699; 6

Tex. Sup. J. 137, Supreme Court of Texas (1962).

South Plains Lamesa Railroad, LTD. and Kitten Family Living Trust v High Plains

Underground Water Conservation District N0.1, 52 S.W.3d 770; 2001 Tex. App.

LEXIS 2497, Court of Appeals of Texas, Seventh District, Amarillo (2001).

State et al. v Heard et al., 146 Tex 139, 204 SW 2d 344, Court of Civil Appeals of Texas, Austin (1946).

State of New Mexico ex rel. Eluid L. Martinez, State Engineer v City of Las Vegas, 118

N.M. 257, 880 P.2d 868, Court of Appeals of New Mexico (1994).

State of Texas et al., Appellants, v. Valmont Plantations et al., Appellees, No. 13583, Civil

Court of Appeals of Texas, San Antonio, 346 S.W.2d 853; 1961 Tex. App. . San Antonio: Civil Court of Appeals, 1961. 
State of Texas v Valmont Plantations, 346 S.W.2d 853; 1961 Tex App. LEXIS 2336 (1961).

The Texas Company v Joe Burkett. Supreme Court of Texas. LEXIS 138 (1927).

Texas Commission on Environmental Quality. "Rights to Surface Water in Texas”, GI-228

(Rev. 3/09). http://www.tceq.state.tx.us/publications/gi/gi-

228.html/at download/file.

United States of America in Behalf of the Pueblo of San Ildefonso v Harley Brewer and Mrs.

Harley Brewer, 184 F.Supp. 377, United States District Court D. New Mexico (1960).

United States of America v Jose I. Abeyta, 632 F.Supp. 1301, United States District Court, D. New Mexico (1986).

United States v Candelaria et al. 271 U.S. 432, 46 S.Ct. 561, Unites States Circuit Court of Appeals for the Eighth Circuit (1925-1926).

UNITED STATES ARMY CORPS OF ENGINEERS, Petitioner, v. HAWKES CO., INC., et al. Respondents On Writ Of Certiorari To The United States Court Of Appeals For The Eighth Circuit BRIEF FOR CALIFORNIA

FARM BUREAU FEDERATION, CALIFORNIA CATTLEMEN'S ASSOCIATION, CALIFORNIA BUILDING INDUSTRY ASSOCIATION, BUILDING INDUSTRY LEGAL DEFENSE FOUNDATION, \& CALIFORNIA BUSINESS PROPERTIES ASSOCIATION AS AMICI CURIAE IN SUPPORT OF RESPONDENTS — PETER PROWS Counsel of Record BRISCOE IVESTER \& BAZEL LLP 155 Sansome Street Seventh Floor San Francisco, CA 94104 (415) 402-2700 pprows@briscoelaw.net. March 2016. 


\section{Books and Journal Articles}

The Alcalde. 1912-1922, Austin: The University of Texas.

Almaráz, Felix D., Jr. . “San Antonio’s Franciscan Missions” the Americas. Vol. XLIV, July 1987.

Anonymous, ed. Muir, Andrew Forest. Austin: The University of Texas Press, 1958.

Armstrong, Ellis L., ed. . History of Public Works in the United States 1776-1976. Chicago: American Public Works Association, 1976.

Arneson, Edward P. . “Early Irrigation in Texas," Volume 25, Number 2, Southwestern Historical Quarterly Online. http://www.tsha.utexas.edu/publications/journals/shq/online/v025/n2/contrib_DIVL1 538 print.html.

Austin, Mattie Alice. "The Municipal Government of San Fernando de Bexar, 1730- 1800." Volume 8, Number 4, Southwestern Historical Quarterly Online. Page 277-352 http://www.tsha.utexas.edu/publications/journals/shq/online/v008/n4/article_1_print .html

Bannon, John Francis. The Spanish Borderlands Frontier, 1513-1821. Albuquerque: The University of New Mexico Press, 1970.

Baxter, John O. Spanish Irrigation in the Taos Valley. Santa Fe: New Mexico State Engineer Office, 1990. (Gift from the New Mexico State Engineer.)

Benoist, Dr. Howard and Flores, Sr. Maria Carolina, C.P. The Spanish Missionary Heritage of the United States. San Antonio: United States Department of the Interior/National Park Service and Los Compadres de San Antonio Missions National Historical Park, 1990.

Blake, Nelson M. . Water for the Cities. Syracuse: Syracuse University Press, 1956. 
Bolton, Herbert E. .

"The Mission as a Frontier Institution in the Spanish-American Colonies." Vol. 23,

No. 1. The American Historical Review (Oct., 1917) 42-61.

- Texas in the Middle Eighteenth Century. Austin: The University of Texas Press, 1970.

Brooks, David B. and Trottier, Julie. "An Agreement to Share Water Between Israelis and Palestinians: the FoEME Proposal.” Czech Republic Development Cooperation with support of the European Union. Amman, Friends of the Middle East, 2012.

Brookings Institution. "Water in the Israel-Palestinian Peace Process: Sharing Resources to Share the Future.” Washington, Brookings Institution, 2013.

Bruggeman and Fisher. Real Estate Finance and Investments, Fourteenth Edition. New York: McGraw-Hill Irwin, 2011.

Burkholder, Mary V. . Down the Acequia Madre. San Antonio: Private, 1976.

The King William Area: A History and Guide to the Houses. San Antonio: Private, 1973. Burns, Robert Ignatius. "Irrigation Taxes in Early Mudjar Valencia: The Problem of the Alfarda." Speculum, Vol. 44, No. 4 (Oct., 1969).

Cabré, Alexander. "Human Right to Environment and Its Effective Protection in Catalonia, Spain and Europe.” International Journal of Legal Information. Spring, 2014. 42 Int'1 J. Legal Info. 121

Casado-Perez, Vanesa. "Missing Water Markets: A Cautionary Tale of Governmental Failure.” New York University Environmental Law Journal. 23 N.Y.U. Envtl. L. J. 157.

Castañeda, Carlos E. . Our Catholic Heritage in Texas, 1519-1936, Vol. I-VII. . Austin: Von Boeckmann-Jones Co., 1938. 
Chabot, Frederick C. With the Makers of San Antonio. San Antonio: Private, 1937.

Chipman, Donald E. . Spanish Texas 1519-1821. Austin: The University of Texas Press, 1992.

Clopper, J. C. . “J.C.Clopper's Journal and Book of Memoranda for 1828.1 Province of Texas," Volume 013, Number 1, Southwestern Historical Quarterly Online, Page $44-80$. http://www.tsha.utexas.edu/publications/journals/shq/online/v013.n1/article_4_print.html Coplin, William D. and O’Leary, Michael K. Public Policy Skills. Croton-on-Hudson (NY), Public Policy Associates, 1988.

Coppini, Pompeo. From Dawn to Sunset. San Antonio: The Naylor Company, 1949.

Cox, I. J. “TheEarly Settlers of San Fernando," Volume 5, Number 2, Southwestern Historical Quarterly Online http://www.tsha.utexas.edu/publications/journals/shq/online/v005/n2/article_6_print html

Cox, I. Waynne. The Spanish Acequias of San Antonio. San Antonio: Maverick Publishing, 2005.

Cresswell, John W.. Research Design: Qualitative, Quantitative, and Mixed Methods Approaches. Los Angeles: Sage Publications, 2014.

Cronon, William. Nature's Metropolis: Chicago and the Great West. New York: W.W. Norton, 1991.

Cuevas, P. Mariano, S.J. . Historia de la Iglesia en Mexico, Tomo IV, 1700-1800. El Paso: Editorial "Revista Catolica," 1928.

Cutter, Charles R. . "Community and the Law in Northern New Spain."the Americas. Vol. L, April 1994. 
De la Teja, Jesús F., ed. . Preparing the Way, Preliminary Studies of the Texas Catholic Historical Society, Number 1. Austin: Texas Catholic Historical Society, 1997.

—. San Antonio de Bexar A Community on New Spain's Northern Frontier.

Albuquerque: University of New Mexico Press, 1995.

De Leon, Arnoldo. The Tejano Community, 1836-1900. Dallas: SMU Press, 1982.

De Stefano, Lucia and Llamas, M. Ramón, ed. Water, Agriculture and the Environment in Spain: can we square the circle? Taylor \& Francis Group, London, UK, 2013.

Department of the Interior. Water Supply and Irrigation Papers of the United States Geological Survey No. 13. Washington: U. S. Government Printing Office, 1896.

Dobbins, Betty Eakle. The Spanish Element in Texas Water Law. Austin: The University of Texas Press, 1959.

Doolittle, William E. . "Agriculture in North America on the Eve of Contact: A Reassessment." Vol. 82, No. 3, Annals of the Association of American Geographers. (Sept., 1992) 386-401.

Elliott, Mark. “If European Union Law is supreme, can Parliament be sovereign?” Public Law for Everyone blog. http://publiclawforeveryone.com/2016/02/21/1000-words-ifeuropean-union-is-supreme-can-parliament-be-sovereign/ . Accessed 04/03/2016.

Everett, Donald E. San Antonio The Flavor of Its Past, 1845-1898. San Antonio: Trinity University Press, 1959.

Fernandez, Gilad. "Economics aspects in Water Management in Israel.” Jerusalem, Water Authority, State of Israel, 2000.

Fireman, Janet R. . The Spanish Royal Corps of Engineers in the Western Borderlands Glendale: The Arthur H. Clark Company, 1977. 
Fisher, Lewis F. Crown Jewel of Texas: The Story of San Antonio's River. San Antonio: Maverick Publishing Company, 1997.

Fornés, Juan Maria. de la Hera, África, Llinas, Ramón, Martínez-Santos, Pedro.

“Legal Aspects of Groundwater Ownership In Spain.” Paris, International Water Resources Association. Vol. 32, No. 4, December 2007.

Foster, William C. . Spanish Expeditions into Texas 1689-1768. Austin: The University of Texas Press, 1995.

Foundation for Middle East Peace. "The Socio-economic Impact of Settlements on Land, Water, and the Palestinian Economy.” Washington. FMEP, 1998.

Friends of the Earth Middle East Priority Initiatives Team. "Cross Border 'Priority Initiatives' of the Good Water Neighbors Project.” Amman, FoEME, 2013.

Gesick, E. John, Jr. Under the Live Oak Tree, A History of Seguin. Seguin: Seguin Bank \& Trust Company, 1988.

Glick, Thomas F. . Islamic and Christian Spain in the Early Middle Ages. Princeton: Princeton University Press, 1979.

Gómez-Limón, J. A., and L. Riesgo. "Water pricing: Analysis of differential impacts on heterogeneous farmers." Water Resources. 20004. Res., 40, W07S05, doi:10.1029/2003WR002205.

Graham, Don. Kings of Texas. Hoboken: John Wiley \& Sons, 2003.

Grant, Sue and Vidler, Chris. Economics in Context. Oxford: Heinemann Educational Providers, 2000.

Green, Christine. "The Tribunal de las Aquas 
Greenhill, Joe R. and Gee, Thomas Gibbs. "Ownership of Ground Water in Texas; The East Case Reconsidered. Texas Law Review, Vol. 33, 1955.

Habig, Marion A. . The Alamo Chain of Missions. Chicago: Franciscan Herald Press, 1968.

—. San Antonio’s Mission San Jose. Chicago: Franciscan Herald Press, 1968.

Hall, Molly Elizabeth. "Environmental Law in the European Union: A New Approach to Enforcement". Tulane Environmental Law Journal. Summer, 2007. 20 Tul.Envtl.L.J. 278.

Handy, Mary Olivia. History of Fort Sam Houston. San Antonio: The Naylor Press, 1951. James M. Henslin. Social Problems: A Down-To-Earth Approach. Boston: Pearson, 2011. Highsmith, Richard M., Jr. . "Irrigated Lands of the World,” Vol. 55, No. 3, Geographical Review. (Jul., 1965) 382-389.

Hildebrand, Ira P. "The Rights of Riparian Owners at Common Law in Texas, ” Texas Law Review, 6 (1927-1928)

House, Boyce. San Antonio City of Flaming Adventure. San Antonio: The Naylor Company, 1949.

Hundley, Jr. Norris. The Great Thirst: Californians and Water-A History. Revised Ed. Berkeley: University of California Press, 2001.

Hunt, Robert C. and Hunt, Eva. "Canal Irrigation and Local Social Organization.” Vol. 17, No. 3. Current Anthropology (Sept., 1976) 389-411.

Hutchins, Wells A. "The Community Acequia: Its Origin and Development," Volume 031, Number 3, Southwestern Historical Quarterly Online, Page 281-284. http://www.tsha.utexas.edu/publications/journals/shq/online/v031/n3/article_5_print.html Hutchins, Wells A. The Texas Law of Water Rights. Austin: The Texas Legislature and Texas Board of Water Engineers, 1961. 
Isaac, Jad. “Core Issues of the Palestinian-Israeli Water Dispute.” Jerusalem, Applied Research Institute, 1994.

Jackson, Jack. Los Mesteños. College Station: Texas A \& M Press, 1986.

Jackson, Robert H. and Castillo, Eduardo. Indians, Franciscans, and Spanish Colonization. Albuquerque: University of New Mexico Press, 1995.

Jackson, Robert H. . Missions and the Frontiers of Spanish America. Scottsdale: Pentacle Press, 2005.

Keinan, Tamar. "Water Justice: Water as a Human Right in Israel." Amman: Friends of the Middle East, 2005.

Kelly, William W. . "Concepts in the Anthropological Study of Irrigation,” Vol. 85, No. 4, American Anthropologist, New Series (Dec. 1983) 880-886.

Koek, Elizabeth. "Water for One People Only: Discriminatory Access and 'Water Apartheid' in the OPT". Ramallah - West Bank - Palestine: Al-Haq, 2013.

Kwasniak, Arlene J. "Inflating and Deflating: Courts and State/Crown Ownership and Management of Water.” Public Land \& Resources Law Review. 33 Pub. Land \& Resources L. Rev. 95. 2012.

Lea, Tom. The King Ranch, I and II. Boston: Little, Brown \& Co., 1957.

Leal, John Odgen, Bexar County Archivist. After the Secularization of the Mission San Antonio de Valero, Known as the Alamo, 1792. San Antonio: Bexar County, 1991. Leutenegger, Benedict tr. with intro. and notes by Habig, Marion A., O.F.M., and Diekemper, Barnabas, O.F.M. . "Memorial of Father Benito Fernández Concerning the Canary Islanders, 1741." Southwest Historical Quarterly. Vol. 82, No. 3.

Lin, Albert C. "Fracking and Federalism: A Comparative Approach to Reconciling National 
and Subnational Interests in the United States and Spain." Environmental Law. 44 Envtl. L. 1039.

Louka, Elli. Water Law and Policy. (New York, Oxford University Press, 2008)

Maas, Arthur and Anderson, Raymond L. and the Desert Shall Rejoice-Conflict, Growth, and Justice in Arid Environments. Cambridge: MIT Press, 1978.

Mahoney, James. "Revisiting General Theory in Historical Sociology." Social Forces 83:2 (2004): 459-489.

Margat, Jean and van der Gun, Jac. Groundwater Around the World. Taylor and Francis CRC Press. London, 2013.

Marks, Paula Mitchell. Turn Your Eyes to Texas. College Station: Texas A \& M Press, 1989.

Matovina, Timothy M. Tejano Religion and Ethnicity San Antonio, 1821-1860. Austin: University of Texas Press, 1995.

—. Guadalupe and Her Faithful. Baltimore: The Johns Hopkins University Press, 2005.

Matson, Daniel S. and Fontana, Bernard L., ed. tr. . Father Bringas Reports to the King, Methods of Indoctrination on the Frontier of New Spain, 1796-97. Tucson: The University of Arizona Press, 1977.

Mauldin, Raymond P. Exploring Drought in the San Antonio Area Between 1700 and 1979. Center for Archaeological Research. The University of Texas at San Antonio, 2003.

Mesa-Jurado, M. A, J. Berbel, and F. Orgaz. "Estimating marginal value of water for irrigated olive grove with the production function method." Spanish Journal of Agricultural Research 2010 8(S2), S197-S206. 
Meyer, Michael C. . Water in the Hispanic Southwest. Tucson: The University of Arizona Press, 1984.

Miller, Char, Editor. On the Border: An Environmental History of San Antonio. San Antonio: Trinity University Press, 2005.

Montejano, David. Anglos and Mexicans in the Making of Texas, 1836-1986. Austin: The University of Texas Press, 1987.

Moore,Steven A.. Alternate Routes to the Sustainable City: Austin, Curitiba, and Frankfurt. Lanham: Lexington Books, 2007.

Morales, Francisco, O.F.M. . "Mexican Society and the Franciscan Order." The Americas. Vol. LIV, Jan 1998.

Morfi, Fray Father Juan Agustin. The History of Texas 1673-1779, a manuscript written in 1782-1783. Castañeda, Carlos, ed. . Albuquerque: The Quivera Society, 1935.

Newcomb, W.W. The Indians of Texas. Austin: The University of Texas Press, 1961. Escrig-Olmedo, Elena and Muñoz-Torres, María Jesús and Fernández-Izquierdo, María Ángeles. "Sustainable Development and the Financial System: Society’s Perceptions About Socially Responsible Investing”. Business Strategy and the Environment. Bus. Strat. Env. 22, 410-428 (2013).

O'Rourke, Thomas P. . The Franciscan Missions in Texas (1690-1793). unknown publisher, 1927.

Ostrom, Elinor and Gardner, Roy. "Coping with Asymmetries in the Commons: SelfGoverning Irrigation Systems Can Work." Vol. 7, No. 4, The Journal of Economics Perspectives. (Autumn, 1993) 93-112.

Parsons, James J. . "The Migration of Canary Islanders to the Americas: An Unbroken Current Since Columbus.” the Americas. Vol. XXXIX, (April 1983) 447-469. 
Patton, Michael Quinn. Qualitative Evaluation and Research Methods, 2nd Edition.

Newbury Park: Sage Publications, 1990.

Perko, Anthony. "Case Note: Watershed Management: A Comparison Between Efforts in the United States and the European Union." University of Denver Law Review. 16 U. Denv. Water. L. Rev. 166. Fall, 2012.

Phelan, Richard. Texas Wild. New York: E. P. Dutton \& Co. Inc., 1976.

Porter, Charles R., Jr.

------- Bakken, Gordon Morris, ed. “The Hydraulic West: The History of Irrigation.”

Chapter 11, pages 308-335 by Charles Porter. The World of the American West. New York: Routledge, 2011.

- Maker of Modern Texas, George W. Brackenridge. Austin: Publisher pending, 2013.

--------- "Financing Groundwater Conservation Districts in Texas: Results of a Preliminary

Study.” Texas Water Journal. Vol. 4, No. 1, (2013).

"Of Urgent Concern: What Prompted House Bill 162, the Groundwater

Conservation Act of 1949." Published in the papers of the Texas Water Law

Conference, Austin, Texas 2015.

-------- Spanish Water/Anglo Water. College Station: Texas A \& M University Press, 2009.

-------- “Texas Out of Water?” Houston Chronicle, Guest Editorial, October 23, 2011.

------- “The History of W. A. East v. Houston and Texas Central Railway Company, 1904:

Establishment of the Rule of Capture in Texas Water Law or 'He Who Has the Biggest

Pump Gets the Water." East Texas Historical Journal. Vol. 50, No. 2, (Fall 2012): 107-119.

------- "Querétaro in Focus: The Franciscan Missionary Colleges and the Texas Missions."

Catholic Southwest: A Journal of History and Culture 19 (2008). 
------- "Farm and Ranch for Texas Agents.” Accredited continuing education course. Texas Real Estate Commission, Austin, Texas, 2008.

------- "Water Rights for Texas Agents.” Accredited continuing education course. Texas Real Estate Commission, Austin, Texas, 2008.

Poyo, Gerald E. and Hinojosa, Gilberto. Tejano Origins in Eighteenth-Century San Antonio. Austin: The University of Texas Press, 1991.

Queen, Stuart A. ."What is as Community?.” Vol. 1, No. 4, Journal of Social Forces. (May, 1972) 375-382.

Rae, Stephen R. and Minor, Joseph E. . "Early Engineering in the American Southwest," Vol. 99, No. 2, American Society of Civil Engineers Proceedings. (Apr., 1973) 142157.

Ramsdell, Charles W. San Antonio: A Historical and Pictorial Guide. Austin: The University of Texas Press, 1959.

Raup, H. F. . "Transformation of Southern California to a Cultivated Land” Vol. 49, No. 3, Annals of the Association of American Geographers. (Sept., 1959) 58-78.

Rawson, Michael. "The Nature of Water: Reform and the Antebellum Crusade for Municipal Water in Boston.” Environmental History 9:3 (2004): 60 pars. 8 May 2007 http://www.historycooperative.org/journals/eh/9.3/rawson.html.

Reisner, Marc. Cadillac Desert. New York: Viking, 1986.

Ricard, Robert. The Spiritual Conquest of Mexico. Berkeley and Los Angeles: The University of California Press, 1966. Original Title-Conquete Spirituelle du Mexique. Paris: University of Paris, 1933.

Riddell, John Leonard, ed. Breeden, James O. . A Long Ride in Texas, 1855. College Station: Texas A \& M Press, 1994. 
Rivera, Jose A. Acequia Culture. Albuquerque: The University of New Mexico Press, 1988. Rodriquez, Sylvia. Acequia: Water Sharing, Sanctity, and Place. Santa Fe: School for Advanced Research Press, 2006.

Roemer, Dr. Ferdinand, tr. Mueller, Oswald. Roemer's Texas 1845-1847. San Antonio: Standard Printing Company, 1935.

Sanchez, Jose Maria “A Trip to Texas in 1828" Volume 029, Number 4, Southwestern Historical Quarterly Online, 249-288. http://www.tsha.utexas.edu/publications/journals/shq/v029/n4/article_3_print.html

Schuetz, Mardith. "Professional Artisans in the Hispanic Southwest." The Americas. Vol. XL, July 1983.

Shuttleworth, Kate. "How Israel’s war has left Gaza dry.” Unknown, The National, 2015. www.thenational.ae/world/middle-east/how-israels-war-has-left-Gaza-dry,html . Sibley, Marilyn McAdams. George W. Brackenridge, Maverick Philanthropist. Austin: The University of Texas Press, 1973.

Siegel, Seth M. Israel's Solution for a Water-starved World: Let There Be Water. New York: St. Marten's Press, 2015.

Skocpol, Theda (Ed.), Vision and Method in Historical Sociology. London: Cambridge University Press, 1984.

Sneddon, Chris, Usa Leila Harris, Radoslav Dimitrov, Uygar Ozesmi. "Contested Waters: Conflict, Scale, and Sustainability in Aquatic Socioecological Systems." Society and Natural Resources, 15:66 (2002): 663-675.

Stratfor.

-- “The Sea Is a Relief for Spain.” $10^{\text {th }}$ Occasional Water Scarcity Issues Report. Austin, 2015. 
---------- “Industrial Expansion Will Strain Mexico’s Water Resources.” $8^{\text {th }}$ Occasional Water Scarcity Issues Report. Austin, 2015.

Swearingen, Jr., William Scott. Environmental City: People, Place, Politics, and the Meaning of Modern Austin. Austin: University of Texas Press, 2010.

Tal-Spiro, Ori. "Israeli-Palestinian Cooperation on Water Issues". Jersulaem, Center for Research and Information, 2011.

Taleb, Yana Abu. et al.. "Why Cooperate Over Water: Shared Waters of Palestine, Israel and Jordan: Cross-border crises and the need for trans-national solutions." Amman, Friends of the Middle East, 2010.

Taylor, Virginia H. . The Spanish Archives of the General Land Office of Texas. Austin: The Lone Star Press, 1955.

Taylor, William B. . Magistrates of the Sacred. Stanford: Stanford University Press, 1996.

Terán, Manual de, ed. Jackson, Jack, tr. Wheat, John. Texas by Terán: The Diary Kept by General Manual de Terán on His 1828 Inspection of Texas. Austin: The University of Texas at Austin, 2000.

Texas Comptroller of Public Accounts, Forces of Change: Shaping the Future of Texas, Volume II, Part 1(Austin: TCPA, November 1993)

Texas Water Development Board. “A Texan’s Guide to Water and Water Rights Marketing,” Austin: Texas Water Development Board: 2003.

Tijerina, Andrés. Tejanos \& Texas under the Mexican Flag, 1821-1836. College Station: Texas A \& M University Press, 1994.

Torres, Luis. Voices from the San Antonio Missions. Lubbock: Texas Tech University Press, 1997. 
The Water Resources Center at Texas Tech University. The Acequias of San Antonio, Historic American Engineering Record TX-1. Washington: The National Parks Service 1973.

Turton, Anthony and Henwood, Roland (editors). Hydropolitics in the Development World: A South African Perspective. Pretoria: University of Pretoria, 2002.

University of California Drought Management adjusted for acre-feet by the author. http://ucmanagedrought.ucdavis.edu/Agriculture/Crop_Irrigation_Strategies/Corn.

Valenzuela-Bock, Catherina. "Court of Justice of the European Union Orders Greece to Pay Fine for Delay in Implementing Waste Water Directive. 15 Oct. 2015. Brussels. http://ec.europa.eu/. Accessed 22/Oct. 2015.

Water Authority, State of Israel. "The Water Issue Between Israel and the Palestinians.” A powerpoint presentation, 2012.

Weber, David J. The Spanish Frontier in North America. New Haven: Yale University Press, 1992.

- Barbaros: Spaniards and Their Savages in the Age of Enlightment. New Haven: Yale University Press, 2005.

—. The Mexican Frontier 1821-1846 The American Southwest Under Mexico. Albuquerque: University of New Mexico Press, 1982.

—, ed. New Spain's Far Northern Frontier. Dallas: Southern Methodist University Press, 1979.

Weber, David J. and Arnoldo De León, eds. Foreigners in Their Native Land: Historical Roots of the Mexican Americans. Albuquerque: University of New Mexico Press, 1982.

Website of the Edwards Aquifer. www.edwardsaquifer.net. 
Website of the San Antonio Water System (SAWS). www.saws.org.

Weddle, Robert S. . San Juan Bautista—Gateway to Spanish Texas. Austin: The University of Texas Press, 1968.

Wegener, Elaine Hoffman, Editor. George C. Vaughan, Early Entrepreneur. San Antonio: The Watercress Press, 1984. (gift from the Vaughan family and Tom Monroe.)

Weniger, Del. The Explorer's Texas the Land and Waters. Austin: Eakin Press, 1984.

Wheeler, Kenneth W. To Wear A City's Crown: The Beginnings of Urban Growth in Texas, 1836-1865. Cambridge: Harvard University Press, 1968.

White, A. A. and Wilson, Will. "The Flow and Underflow of Motl v. Boyd: The Problem,” Southwestern Law Journal, 9 (1) (1955).

Wood, Alexander. "Watering Down Federal Court Jurisdiction: What Role Do Federal Courts Play in Deciding Water Rights?” Journal of Environmental Law and Litigation. 23 J. Envtl. L. \& Litig. 241. 2008.

Worster, Donald. Rivers of Empire: Water, Aridity, and the Growth of the American West. New York: Pantheon Books, 1985.

Xie, Oliver Hong. "Water: the Real Perpetrator of the Israeli-Palestinian Conflict? 2007. Conference Paper.

Zeitoun, Mark. Power and Water in the Middle East: The Hidden Politics of the Palestinian-Israel Water Conflict. London: I.B. Tauris \& Co Ltd., 2012.

\section{Monographs}

Almaráz, Felix D. . Crossroad of Empire, The Church and State on the Rio Grande Frontier of Coahuila and Texas, 1700-1821, Report No. 1. San Antonio: The University of Texas at San Antonio Center for Archaeological Research, 1979. 
Cox, I. Waynne and Houk, Brett A. Archaeological Monitoring of the HEB-GSA Parking Lot: Impacts to the San Pedro Acequia, Report No. 279. San Antonio: The University of Texas at San Antonio Center for Archaeological Research, 1998.

Cox, Patrick. "Our Water and the Threat to the Heart of Our Existence." Policy: Water, Government, and the People. February 3, 2015. https://texaswaterpolicy.org/2015/02/ .

Cox, I. Waynne. Archaeological Montioring at Espada Road Acequia Crossing, Report No. 221. San Antonio: The University of Texas at San Antonio Center for Archaeological Research, 1993.

- $10^{\text {th }}$ Street Substation Excavation of the Acquia Madre (41 BX 8), Report No. 153. San Antonio: The University of Texas at San Antonio Center for Archaeological Research, 1985.

- Excavations of Portions of the San Pedro Acequia (41 BX 337) and a Search for the Arocha Acequia, Report No. 161. San Antonio: The University of Texas at San Antonio Center for Archaeological Research, 1986.

Frkuska, Augustine. Archaeological Investigations at the San Pedro Acequia, Report No. 103. San Antonio: The University of Texas at San Antonio Center for Archaeological Research, 1981.

Glick, Thomas F. . Southwestern Studies, Monograph No. 35, The Old World Background of The Irrigation System of San Antonio Texas. El Paso: Texas Western Press, 1972. Ivey, Jake. Mission Land Use in the San Antonio River Valley. unknown location and publisher, 1991. Acquired from the Center for Archaeological Research at the University of Texas at San Antonio Library. 
Nickels, David L., Cox, I. Waynne, and Gibson, Connie. Excavation of the San Pedro Acequia on the Grounds of the San Antonio Housing Authority, Report No. 243. San Antonio: The University of Texas at San Antonio Center for Archaeological Research, 1996.

\section{Other Sources}

Aiken, Rob and Lamm, Freddie. "Managing Deficit Sprinkler Irrigation of Sunflower." The Sunflower (February 2011).

Ankrum, Nora. "Water Fall: Between Austin Water's Conservation Goals and its Execution .. Lies a Shadow.” The Austin Chronicle (June 2011). Texas Water Conservation Association. Confluence. Texas Water Conservation Association, 2011.

Aquifer and the Panhandle." Texas Tech Journal of Texas Administrative Law 173 (Summer 2003).

Baade, Hans W. "The Historical Background of Texas Water Law-A Tribute to Jack Pope.”St. Mary’s Law Journal (1986).

Benson, Reed D. "Deflating the Deference Myth: National Interests vs. State Authority under Federal Laws Affecting Water Use.” Utah Law Review 241 (2006).

Bhatia R. and Falkenmark M. "Over Exploitation of Groundwater and its Adverse Effects." ICWE, Dublin, Ireland (1992).

Blankenship, Grant. "Drought Spreads Pain From Florida to Arizona." The New York Times (July 2011).

Bogener, Stephen. Ditches Across the Desert: Irrigation in the Lower Pecos Valley. Texas Tech University Press, 2003.

Booth, F.R. “Adjudication on Water.” North Texas Bar Association (1967).

Brody, Jane E. "Water Holds Pleasures, And Menaces That Lurk.” The New York Times (July 2011). 
Bullock, Bob and Hubert, Martin. "Senate Bill 1, The First Big and Bold Step Toward Meeting Texas's Future Water Needs.” 30 Texas Tech Law Review 53 (1999).

Campbell, Augustus L. "Texas Watermasters: A Legal History and Analysis of Surface Water Rights Enforcement.” Texas Tech Administrative Law Journal 143 (Spring 2006).

Campoy, Ana and Gold, Russell. "Oil's Growing Thirst for Water.” The Wall Street Journal (December 2011).

Canseco, Susana Elena. 'Landowner's Rights in Texas Groundwater: How and Why Texas Courts Should Determine Landowners Do Not Own Groundwater in Place.” Baylor Law Review (Spring 2008).

Caroom, Doug and Elliot, Paul. "Water Rights Adjudication-Texas Style.” Texas Bar Journal (November 1981).

Caroom, Douglas G. and Maxwell, Susan M. "Overview of Texas Water Rights and Water Development." The University of Texas School of Law (2008).

Caughey, John and Mares, Jose Fuentes. "Adjudication of the Water Rights in the Middle Rio Grande River and its Contributing Tributaries." Library of Sherry L. Peel Attorney at Law Austin, Texas (1979).

Caughey, John. “The Pueblo Water Right of Laredo." Library of Sherry L. Peel Attorney at Law Austin, Texas (July 1979).

Chahin, Dinniah M. "Is the Once Mighty River not so Mighty?: How the Distribution of Water Rights and Water Planning Along the Texas Portion of the Rio Grande River Affects Future Texans." 6 Texas Tech Journal of Texas Administrative Law 115 (Spring 2005). 
Clayton, Jeffrey J. "Here is a Land Where Life is Written in Water": Re-Writing Western Water Law in the $21^{\text {st }}$ Century." 5 University of Denver Water Law Review 525 (Spring 2002).

Combs, Susan. 'Liquid Assets: The State of Texas' Water Resources.” Austin: Texas Comptroller of Public Accounts (Winter 2009).

Davis, Jeff J. and McElroy Scott B. "Revisiting Colorado River Water Conservation District v. United States_-There Must be a Better Way.” 27 Arizona State Law Journal 597 (Summer 1995).

De la Teja, Jesús F. "Land and Society in $18^{\text {th }}$ Century San Antonio de Bexar A Community on New Spain’s Northern Frontier.” Dissertation. Austin: University of Texas at Austin, 1988.

Dean, Lyn E. and Johnson, Russell S. "The Changing Face of Water Rights in Texas 2003." State Bar of Texas (2003).

Drummond, Dylan O. “Groundwater Ownership in Place: Fact or Fiction?” The University of Texas Law School (December 2008).

Drummond, Dylan O. “Texas Groundwater Law in the Twenty-First Century: A Compendium of Historical Approaches, Current Problems, and Future Solutions Focusing on the High Plains

Drummond, Dylan O. "Texas Groundwater Rights and Immunities: From East to Sipriano and Beyond." (2011).

Dumars, Charles T. “Changing Interpretations of New Mexico's Constitutional Provisions Allocating Water Resources: Integrating Private Property Rights and Public Values.” 26 New Mexico Law Review 367 (Summer 1996). 
Dumars, Charles T., O'Leary, Marilyn, Utton, Albert E. Pueblo Indian Water Rights: Struggle for a Precious Resource. The University of Arizona Press, 1984.

Duncan, Robert. “Amicus Brief for The Edwards Aquifer Authority and the State of Texas v. Burrell Day and Joel McDaniel, Cause No. 08-0964.” (Letter sent to Mr. Blake A. Hawthorne). Robert Duncan: Texas Senate District 28 (June 2010).

Dunlap, Philip. "Border Wars: Analyzing the Dispute over Groundwater Between Texas and Mexico." Law and Business Review of the Americans (Spring 2006).

Eckstein, Gabriel. “Application of International Water Law to Transboundary Groundwater Resources, and the Slovak-Hungarian Dispute Over Gabcikovo-Nagymaros.” International Water Law Project (2010).

Eckstein, Gabriel. "Precious, Worthless, or Immeasurable: The Value and Ethic of Water." 38 Texas Tech Law Review 963 (Summer 2006).

Elder, Robert Jr. "Water wars in Texas.” Cox News Service (2003).

Ellis, Gregory M. and Houston, Jace A. "Overview of Regulatory Methods Available to Groundwater Conservation Districts.” (May 2004).

Ellis, Gregory M. "Regulatory Takings and Texas Groundwater.” Unpublished.

Flannery, Tim. The Eternal Frontier: An Ecological History of North America and its Peoples. New York: Atlantic Monthly Press, 2001.

Fox, Nicole. "Should Groundwater Be Owned by the State of Texas?" Charles Porter (August 2011).

Galant, Carl R. and Johnson, Russell S. "Exempt Uses of Groundwater and Surface Water." State Bar of Texas Volume 33, Number 3 (March 2009).

Galbraith, Kate. “Texas' Water Rights System Gets Tested in Drought." The Texas Tribune (2012). 
Glennon, Robert. Water Follies: Groundwater Pumping and the Fate of America's Fresh Waters. Island Press, 2002.

Green, Donald E. Land of the Underground Rain: Irrigation on the Texas High Plains, 1910-1970. Austin and London: University of Texas Press, 1973.

Greenhill, Joe R. and Gee, Thomas Gibbs. "Ownership of Ground Water in Texas; The East Case Reconsidered.” Texas Law Review (1955).

Gvirtzman, Haimi. “The Truth Behind the Palestinian Water Libels”. BESA Center Perspectives Paper No. 238, February 24, 2014. Published by the Begin-Sadat Center for Strategic Studies and found at http://besacenter.org/perspectivespapers/truth-behind-palestinian-water-libels/

Gutierrez, Tony. "When the Water Runs Out.” Austin American-Statesman (August 2011). Hall, Katy. "Dry Fire Hydrants Helping Counter Rural Wildfires.” http://www.texasfire.com (March 1995).

Hardberger, Amy. "What Lies Beneath: Determining the Necessity of International Groundwater Policy Along the United States-Mexico Border and a Roadmap to an Agreement.” 35 Texas Tech Law Review 1211 (Summer 2004).

Harrison, Sylvia. "The Historical Development of Nevada Water Law." 5 University of Denver Water Law Review 148 (Fall 2001).

Hassan, Mohammad Masud. “GAM Run 10-050 MAG Version 2.” Texas Water Development Board (February 2011).

Hays Trinity Conservation District. "Hays Trinity Groundwater Conservation District Rules.” State of Texas (June 2007).

Hildebrand, Ira P. "The Rights of Riparian Owners at Common Law in Texas." Texas Law Review (1927-1928). 
Horton, Alex W. "Where'd All the (Ground) Water Go? Three Approaches to Balancing Resource Efficiency with Rural Sustainability in Texas." South Texas Law Review 691 (Spring 2008).

House Research Organization. "Behind the US-Mexico Water Treaty Dispute." Texas House of Representative: Interim News (April 2002).

Howell, Emily. "Is the TCEQ "Hearing” Impaired?: The Impact of City of Marshall v. City of Uncertain on the Availability of Contested-Case Hearings for Water Use Permit Amendments." Texas Tech Administrative Law Journal 299 (Summer 2007).

Hutchins, Wells A. The Texas Law of Water Rights. The State of Texas, Board of Water Engineers, 1961.

Janner, Jay. "Rising Bills Tapping Central Texans Dry.” Austin American-Statesman (December 2011).

Johnson, Russell S. "Water Market Transfer and Value Issues.” (2002)

Kaiser, Ronald. "Deep Trouble: Options for Managing the Hidden Threat of Aquifer Depletion in Texas." 32 Texas Tech Law Review 249 (2001).

Kaiser, Ronald. "Water Marketing in Texas.” Texas A\&M University (2001).

Kelton, Elmer. The Time It Never Rained. Fort Worth: TCU Press, 1984.

Kunkel, Eric B. "The Spanish Law of Waters in the United States: From Alfonso the Wise to the Present Day." McGeorge School of Law (2001).

MacKinnon, Anne. "Historic and Future Challenges in Western Water Law: The Case of Wyoming." 6 Wyoming Law Review 291 (2006).

Mason, Thomas G. and Melvin, Robin A. . 'New Developments in Texas Water Law, Planning and Management." Presented to the Austin Bar Association Real Estate Section Meeting, March 6, 2012. 
Marin, Carlos. "Bi-National Border Water Supply Issues from the Perspective of the IBWC.” 11 United States-Mexico Law Journal 35 (Spring 2003).

Mashhood, Farzad. "Legislator Draws up Water Plan.” Austin American-Statesman (January 2012).

McCleskey, Robert A. "Maybe Oil and Water Should Mix_At Least in Texas Law: An Analysis of Current Problems with Texas Ground Water Law and How Established Oil and Gas Law Could Provide Appropriate Solutions.” Texas Wesleyan Law Review 207 (Spring 1994).

Menger, Johnowene Brackenridge Crutcher. "M. Eleanor Brackenridge, 1837-1924, A Third Generation Advocate of Education.” Masters’ Thesis. San Antonio: Trinity University, 1964.

Morgan, Bobbie Whitten. “George W. Brackenridge and His Control of San Antonio’s Water Supply, 1869-1905.” Master's Thesis. San Antonio: Trinity University, 1961.

Motal, Becky. "LCRA Setting Up for Long Drought.” Austin American-Statesman (January 2012).

National Research Council. A New Era for Irrigation. National Academy Press, 1996.

Neal, Basil Young. “George W. Brackenridge: Citizen and Philanthropist.” Master's Thesis. Austin: The University of Texas at Austin, 1939.

Neuman, Janet C. "The Good, The Bad, and The Ugly: The First Ten Years of the Oregon Water Trust.” 83 Nebraska Law Review 432 (2004).

Pisani, Donald J. From the Family Farm to Agribusiness: The Irrigation Crusade in California and the West, 1850-1931. University of California Press, 1984.

Pisani, Donald J. To Reclaim a Divided West: Water, Law and Public Policy, 1848-1902. Albuquerque: University of New Mexico Press, 1992. 
Pisani, Donald J. Water, Land and Law in the West: The Limits of Public Policy, 18501920. University Press of Kansas, 1996.

Pleven, Liam. "Betting on a Water Boom.” The Wall Street Journal (December 2011).

Reich, Peter L. "The "Hispanic" Roots of Prior Appropriation in Arizona." 27 Arizona State Law Journal 649 (Summer 1995).

Rice, Jenny. Distant Publics: Rhetoric and the Subject of Development Crisis. Pittsburgh: University of Pittsburgh Press, 2012.

Rodriguez, Sylvia. Acequia: Water Sharing, Sanctity, and Place. A School for Advanced Research Resident Scholar Book, 2006.

Sahs, Mary K. “Groundwater Regulation in Texas.” State Bar of Texas (2005).

Sansom, Andrew. Water in Texas. University of Texas Press, 2008.

Schorr, David B. "Appropriation as Agrarianism: Distributive Justice in the Creation of Property Rights.” Ecology Law Quarterly (2005).

Smith, Garland F. "The Valley Water Suit and it's Impact on Texas Water Policy: Some Practical Advice for the Future.” Texas Tech Law Review (1977).

Smith, Tiziana. "Overcoming Challenges in Wastewater Reuse: A Case Study of San Antonio, Texas.” Cambridge, Massachusetts: Harvard College (March 2011).

Texas Alliance of Groundwater Districts. "Legislative Wrap-Up: Groundwater-Related Bills.” (2011).

Texas Alliance of Groundwater Districts. "Position Paper for the $82^{\text {nd }}$ Legislature." (July 2010).

Texas Farm Bureau. "Joint Position Statement on Groundwater Ownership.”

Texas Natural Resource Conservation Commission. "Rights to Surface Water in Texas." (2002). 
Texas Water Code. Water Rights, Chapter 11. Texas Natural Resource Conservative Commision (1977).

Texas Water Development Board. 100 Years of Rule of Capture: From East to Groundwater Management. Report 361. Texas Water Development Board, June 2004.

Texas Water Development Board. The Texas Manual on Rainwater Harvesting. Texas Water Development Board, Third Edition, 2005.

Texas Water Development Board. Water for Texas 2007. Texas Water Development Board (January 2007).

Underwood, Laura. "Better Late than Never: States Regain the Right to Regulate Stream Flows Under the Clean Water Act: Pud N0.1 of Jefferson County v. Washington Department of Ecology.” 26 Texas Tech Law Review 187 (1995).

United Nations Conference on Trade and Development. "Report on UNCTAD assistance to the Palestinian People: Developments in the economy of the Occupied Palestinian Territory.” New York, United Nations, 2015.

United States Environmental Protection Agency. "Drinking Water From Household Wells." (January 2002).

Votteler, Todd H. "The Little Fish That Roared: The Endangered Species Act, State Groundwater Law, and Private Property Rights Collide Over the Texas Edwards Aquifer." Lewis \& Clark Law School Environment Law 845 (Winter 1998).

Vattaman, Dan. "The Court of Justice of the European Union After the Reform Established by the Lisbon Treaty." International Journal of Law and Jurisprudence Online Semiannually. Romania. Union of Jurists of Romania and Universul Jurdic Publishing House. Vol. V, Issue 2, July-December, posted at $4^{\text {th }}$ December 2015. 
Votteler, Todd H. Texas Water Journal. Texas Water Resources Institute (September 2010). WRAP. "A Comparative Study of Water Data Across Israel, West Bank and Jordan." 2013. Walker, Andrew. "Mexican Law and the Texas Courts." Baylor Law Review (Winter 2003). White, A. A. and Wilson, Will. "The Flow and Underflow of Motl v. Boyd the Problem." Southern Methodist University: Southwestern Law Journal (Winter 1955).

Williams, Michael L. "Can Oil and Water Mix? The Impact of Water Law on Oil, Gas, and Mineral Production.” 68 Texas Bar Journal 816 (October 2005).

Wolf, Aaron T. and Newton, Joshua T.. Case Study of Transboundary Dispute Resolution: The Indus Water Treaty. http://www.transboundarywaters.orst.edu/research/case_studies/Indus_New.htm, accessed March 3, 2016. 
Speeches and Presentations of Charles Porter on Water Issues from 2007-Spring 2016

2016 Presenter at Spain's Encounter with the New World Symposium by the Bexar County Inaugural Symposium of San Antonio's Tricentennial Celebration on May 7, 2016. The Bexar County Historical Commission and Dr. Felix D. Almaraz, Jr., PhD, Knight of Spain, Tricentennial Chair to write and speak at the. My paper and presentation is titled "The Expansive Geography of Texas: Liabilities and Assets." I am one of only 5 academics asked to present at this $300^{\text {th }}$ anniversary of the founding of the $7^{\text {th }}$ largest city in the United States.

2016 Presenter at the $26^{\text {th }}$ Annual Land Conference, Texas A\&M University, San Antonio, April 28. "Texas Water Law: A Historical Perspective."

2016 Presenter at the Kozmetsky Center's Migration and Displacement Symposium, Austin, Texas, "A Perspective of Displacement on the Texas Border with Mexico."

2016 Presenter at an international academic conference, the Academic and Business Research Institute conference in San Antonio, March, 2016. My topic title was "Water as the Ultimate Weapon of International Social Control." The Chairman of the Conference in Florida asked me for an encore presentation in San Antonio as their guest lecturer.

2016 Presenter at an international academic conference, the Academic and Business Research Institute conference in Orlando, Florida January $7-9,2016$. My topic title is "Water as the Ultimate Weapon of International Social Control."

2016 Presented at the Texas State Historical Association's Annual Conference in Irving, Texas on March 3, 2016 by invitation. My presentation is "Chaos, Change, Yet Triumph: Mexican-American Community Formation in 19th Century Texas."

2016 Presenter and panel organizer at The University of Texas Energy Week, 2016. My topic is "The Nexus of Water Policy and Energy in Texas."

2015 Keynote speaker at the October 16 New Braunfels Chamber of Commerce Natural Resources Committee Water Strategies \#2. My presentation is titled "Water Policy for Texas: Past and Present Strategies.”

2015 Featured speaker at the Texas Water Law Conference in Austin on October 6. I am a member of the faculty of this conference which provides continuing education credit for attorneys. We expect 400 attendees. My peer-reviewed and published paper is titled: " $\boldsymbol{O} \boldsymbol{f}$ Urgent Concern” - What Prompted House Bill 162, the Groundwater Conservation Act of 1949.

2015 Organizer and moderator/presenter at the Lone Star Water Forum in Brenham, Texas October 3. I selected the topic question: "Deslination in Texas: The Ultimate Solution?" 
2015 Presenter at the East Texas Historical Association's Annual Conference in Nacogdoches, Texas on October 8. I will present my paper, “A Want-to-be General in a Fog: Drought and Sibley's New Mexico Campaign."

2015 Special Presentation for Independence Title Buda, Texas, my presentation was titled “Water Policy Issues in Texas: What Real Estate Agents Need to Know."

2015 Featured speaker and moderator at the Austin Board of Realtors Water Forum in Austin on May 27, attended by 400 people.

2015 Keynote speaker at Blinn College in Brenham, Texas on June 17, “Water Challenges in Central Texas," attended by 127 people.

2015 Keynote speaker at a luncheon held by the Texas Rural Water Association in Austin on June 24, “Water Policies in Texas.”

2015 Keynote speaker at the Texas Economic Development Council's Legislative Update in Austin, title of my presentation was “Water Implications in Drought-Ridden Rapidly Growing Texas."

2015 Featured speaker at the International Right of Way Association 2015 Seminar in Grapevine, Texas, the title of my presentation was “An Update on Water Rights in the 84 Texas Legislative Session."

2015 Keynote speaker for international extremism experts at the Kozmetsky Center for Excellence in Global Finance, title of my presentation was "Ongoing and Continuing Violent "Extremism" in Texas: Not Promulgated by Texan Militias or other Groups, but ...Mexico-based Drug “Cartels” and/or Gangs.”

2015 Keynote speaker at the World History Association of Texas Academic Conference, title of my presentation was "Protecting the Borders of the Past: UNESCO World Heritage and the San Antonio Franciscan Mission: by Charles Porter Member of the National Parks Service World Heritage International Experts Committee for the United States of America Nomination of the San Antonio Missions to the UNESCO World Heritage List."

2015 Keynote speaker at the South Central Texas Board of Realtor's luncheon, title of my presentation was “Agents' Duties in Texas Water Policy."

2015 Keynote speaker at the luncheon at Blinn College, title of my presentation was "Enduring Women for Lifetime L E A R N I N G in Brenham, Texas."

2015 Keynote speaker at the San Marcos Rotary Club luncheons (2) and South Austin Rotary Club luncheon, title of my presentation was "Updates on Water Policy Issues of the $84^{\text {th }}$ Texas Legislature." 
2015 Featured speaker at the 2015 Texas Master Gardner Conference in Belton, Texas attended by 600, title of my presentation was "Sharing the Common Pool: Water Rights in the Everyday Lives of Texans."

2015 Featured speaker at the $16^{\text {th }}$ Annual Changing Face of Water Rights

State Bar of Texas San Antonio, February 26-27, 2015, title of my presentation was "What You Think You Know About the History of Texas Water . . But Don't."

2015 Kickoff and keynote speaker at the Texas A \& M University Center for Heritage Conservation Symposium on Preservation of the Alamo, my presentation was titled "180 Years of Heritage Preservation: The Contribution of Blas Herrera and His Descendants to the Story of the Alamo and $19^{\text {th }}$ Century Tejano Architecture And A Tribute to the San Antonio Conservation Society, The SACS Historic Farm and Ranch Complexes Committee Kay Hindes, Pat Ezell, Patsy Castanon, Joanne Parrish, Fran Gale and Evie Herrera Patton."

2014 Keynote Speaker at the First Texas Hill Country Water Summit, title of my presentation was "Strategies for Short and Long Term Challenges."

2014 "A Perspective on Realistic and Sustainable Water Policy: Workable Solutions for a Bright Future" presented at the $6^{\text {th }}$ Annual Lone Star Water Forum. October 4. Brenham.

2014 Organizer and moderator at the $6^{\text {th }}$ Annual Lone Star Water Conference in Brenham, Texas attended by 200 sponsored by Texas A\&M University, Texas Parks and Wildlife, Texas AgriLife Center Texas A\&M University, the City of Brenham - topic a 6 hour presentation and community debate "What is Water Worth to You? Solutions." October. Porter organized and solicited the speakers: Senator Craig Estes, House of Representative Member Doug Miller, Former Mayor of Houston Bill White, and James Murphy Counsel and Operating Manager of the Bexar-Brazos River Authority.

2014 “65 Years of Groundwater Conservation Districts in Texas: Still Undisclosed in Section

5.008 of the Texas Property Code" published and presented at the $24^{\text {th }}$ Annual Superconference Texas Water Law. CLE Water Law Institute. September 22. Austin.

2014 “Moot Mediations in Global Transboundary Water Disputes: Teaching Peaceful Problem-Solving in International Water Relations" presented at the World Council for Curriculum and Instruction 16th World Conference on Education Integrating Education for a Lasting Culture of Peace and Care of Planet Earth. August 22. San Diego.

2014 “Texas Out of Water” Summer Scholar Series, St. Edward's University. Austin.

2014 "Sharing the Common Pool: Water Rights in the Everyday Lives of Texans" webinar for the Texas Land Title Association. Austin.

2014 Texas Alliance of Groundwater Districts Quarterly Meeting, opening speaker, “Unrealized and Undisclosed: Groundwater Conservation Districts in Texas." Austin. 
2014 “Water Rights 101: Unrealized and Undisclosed" published and presented at the South Texas College of Law $29^{\text {th }}$ Annual Real Estate Law Conference June 6, Houston.

2014 Invited panel member for presentation of the Texas A \& M University Bush School graduate students Capstone Report on Water Uses in the Eagleford Shale to Railroad Commissioner Christie Craddick and representatives of the Texas Water Development Board, the Texas Commission on Environmental Quality, the Attorney General's Office and other state officials in Craddick's office April.

2014 Panel Chair and Presenter at the World History Association of Texas Conference, March 1. Paper presented - “Barbed Wire in War: Physical and Social Enclosure in World War I."

2014 Interview by the Austin Chamber of Commerce official Drew Scheberle, Senior Vice President Federal/State Advocacy \& Education/Talent Development on water issues in Austin.

2014 'General Information on Groundwater Districts for ABOR's Risk Reduction Committee"

published by the Austin Board of Realtors and also the Texas Association of Realtors Public Policy Infrastructure and Utilities Subcommittee. June, 2014. Austin.

2014 “Water Rights in Texas” lecturer at University of Texas School of Law for the Edward

Clark Centennial Professor Jane Cohen's class titled WATER LAW AND POLICY: THE INTRODUCTORY COURSE. Austin.

2014 “Who Owns the Water: Sharing the Common Pool-Water Rights in the Everyday Lives of Texans." Webinar for the Texas Wildlife Association. Austin.

2014 Presentation to State Senator Craig Estes - "A Summary of the Lone Star Water Conference" held in Brenham, Texas October, 2013, January.

2014 Organizer and Chair of the Water Rights Roundtable made up of a dozen active water rights attorneys and personnel of Groundwater Conservation Districts to determine legislative agendas for the upcoming $84^{\text {th }}$ Session of the Texas Legislature, February.

2013 Keynote speaker at the Bosque County Hay Show in Meridian, Texas - title "Urban vs. Rural: Which lifestyle do Texans choose?” October.

2013 Organizer and moderator at the $5^{\text {th }}$ Annual Lone Star Water Conference in Brenham, Texas attended by 200 sponsored by Texas A\&M University, Texas Parks and Wildlife, Texas AgriLife Center Texas A\&M University, the City of Brenham - topic a 6 hour presentation and community debate "Should Washington County Have a Groundwater Conservation District" October. Porter selected the presenting attorneys and hydrogeologist and reviewed/edited their presentations. Porter also presented "A History of 
Groundwater Conservation Districts in Texas."

2013 “Prelude to Community: Water Development in Spanish Colonial Texas” for Dr. William Doolittle at the Collegium of the University of Texas Geography Department.

\section{3 "Sharing the Common Pool: Water Rights in the Everyday Lives of Texans"} webinar for the Texas Association of Realtors. Austin.

2013 Moderator of the Panel - "Financing the Solution" at the Texas Capitol Auditorium, a panel discussion of the new bills to finance the State Water Plan of 2012 with Senator Troy Fraser, Chair of the Senate Natural Resources Committee, Representative Allan Ritter, Chair of the House Natural Resources Committee, and Lewis McMahan, Board Member of the Texas Water Development Board. January.

2013 Quest Lectures - University of Texas Division of Continuing and Innovative Education at the Thompson Conference Center - Series "Texas Water: It's Past, Present, and Future" - Porter's lecture: "The History of Texas Water Law, Policy, and Management" October 3.

2013 Sage Lectures CE 140001I- University of Texas Division of Continuing and Innovative Education at the Thompson Conference Center - Series "Water in Texas: Good to the Last Drop"- Porter taught 2 of the 6 lectures to an audience of 150. Porter's topic CE 14001 Ia - "Water in Texas: The Common Denominator of Life" and Porter's topic CE 14001 Ic - "Sharing the Common Pool: Water Rights in the Everyday Lives of Texans" September 16 and September 30.

2013 Moderator of the Legal Update Panel for The Texas Groundwater Summit attended by 500 at the San Marcos Convention Center, August.

2013 City of Sunset Valley City Council invited guest speaker on groundwater permits versus the existing City of Austin water contract, July.

2013 Presenter and Emcee of the opening of the Enduring Women exhibit at the Bullock Texas State History Museum. The exhibit is the product of a class Porter created with Dr. Mary Brantl and co-taught at St. Edward's University to fulfill the collaborative contract between St. Edward's University and the Bullock Texas State History Museum. February.

2013 Moderator of the Panel - "Groundwater Management and Allocation:

Groundwater Allocation after Guitar and Day" Charles Porter, Presenter and Moderator, J.D. Head presenter, Tim Brown presenter, and Ed McCarthy presenter. At the Texas Water Law Conference "Water for the Future: Texas at the Crossroads" a conference sponsored by the Texas Rural Water Association and the Texas Water Conservation Association. January.

2012 Sole Lecturer - Austin Board of Realtors Managing Broker Forum on Ethical Practices "The Fiduciary Duties of Texas Real Estate Licensees: An Explanation of the License Act and the Rules of the Texas Real Estate Commission including Texas Common Law Duties” December. 
2012 Lone Star Water Law Conference. Brenham. Lecturer. "Water Rights Primer" October.

2012 “The Big Read” - Brenham - Adult Education - Emcee and presenter for a community read of Elmer Kelton and his famous book The Time It Never Rained. The event was attended by 250 people. October.

2012 Guest lecturer at Blinn College, Brenham, 2 classes "Water Rights and Agribusiness in Texas" October.

2012 National Parks Service. San Antonio. Guest Editor/Reviewer."Application by the National Parks Service San Antonio River Missions for World Heritage Nomination by UNESCO: for ICOMOS United States and International" as a member of the International Expert's Committee of the National Parks Service. October

2012 Texas Turfgrass Association Convention. San Antonio. Presenter “300 Years of Water Management in Texas: How Regulations and Drought Will Impact the Business of Golf”' October.

2012 Sons of the Texas Revolution. Austin. Presenter. "Sharing the Common Pool: The History of Water Rights in Texas" October.

2012 Austin Executives Association Wednesday Luncheon Speaker's Series. Guest Speaker. “Water Rights in Texas Today” October.

2012 Bell County Water Symposium. Belton, Texas. Presenter. “From Viceroys to GCDs: 300 Years of Groundwater Management” October.

2012 Austin Board of Realtors. "New Member Orientation" - Lecturer. "The National Association of Realtors Code of Ethics: Relationships to Texas Law" October.

2012 Faculty Member and Presenter at the Texas Water Law Superconference, "Water Rights and Everyday Real Estate Transactions" for continuing education credit for attorneys. September.

2012 Keynote Speaker for the Texas Groundwater Summit, "300 Years of Water Management

in Texas: From Viceroys to GCDs" Austin, Texas A conference sponsored by the Texas Alliance of Groundwater Districts. August.

2012 World History Association Annual National Convention. Albuquerque.Presenter. “Bells and Belfries: Control or Comfort for the Indians of the San Antonio Missions" June. 
2012 Webinar, Austin Board of Realtors attended by up to 10,000 people over the past 6 months. "Groundwater in the $21^{\text {st }}$ Century: A Discussion with Charles Porter and Kirk Holland" August.

2012 Webinar, Texas Association of Realtors attended by 700+ people. Expert and sole presenter. "Water Rights in Texas" July.

2012 Oak Hill Professional Business Club Luncheon Speaker Series. Guest Speaker. "Update on Water Rights in Texas" June.

2012 Sons of the American Revolution. Austin. Presenter. "Sharing the Common Pool: The History of Water Rights in Texas" - September.

2012 Panelist and Guest Speaker for Senator Kirk Watson's and the Austin Board of Realtors' "Water for Central Texas: Solving the Problem." Panelists include: Texas House of Representative Member Paul Workman, Dr. Robert Mace, Deputy Executive Administrator of the Texas Water Development Board, Becky Motal, General Manager of the Lower Colorado River Authority, Laura Huffman, Director of The Nature Conservancy of Texas, Charles Porter Author and St. Edward's University Assistant Professor and Texas Water Rights Expert. March.

2012 Guest Speaker, International Right of Way Association, Arlington, Texas, “Right of Way for Interbasin Water Lines. "April.

2012 Invited expert and attendee at the International Expert's Meeting of the National Parks Service in San Antonio to discuss the draft of the application of San Antonio's Franciscan Missions as a UNESCO World Heritage site. March.

2012 Texas State Historical Association Convention, Commentator, "Private Libraries and Collections," Houston, March.

2012 Guest Speaker, Querencia Study Group, Austin, Texas "Sharing the Common Pool" March.

2012 Guest Speaker in the Speaker Seriest of the State of Texas Archives Library "The Next Texas Water War." March.

2012 Attendee and participant in the Austin Bar Association's Real Estate Committee Breakfast - “Water in Texas After Day McDaniel. ”March.

2012 Guest Lecturer at Fran Gale's University of Texas Graduate Architectural Materials Lab class in the field at the Blas Hererra Historic Home in Bexar County, Texas. " $A \boldsymbol{n}$ Overview of Land Classifications, Irrigation, and Land Transfer in Spanish Colonial Texas." February.

2012 Presenter at the World History Association Conference, "The Marriage of Interdependent Irrigation Technologies in New Spain: Prelude to Formation of a Spanish 
Community, Villa San Fernando,” February.

2012 Guest Speaker at the University of Texas LAMP (Learning Activities for Mature People) Series, "How Texas Water Law and Water Rights Shaped Texas and the Perception of Texas Today," January and April.

2011 Expert Lecturer, Co-Designer, and Co-Organizer of 7 Water Workshops for CULF 3330 and CULF 3331, St. Edward's University, overseer of 110 moot mediations of international river basin disputes, teaching 16 student intern mediation techniques along with over 600 student participants. Fall.

2011 Organizer, Water Workshops Texas Water Policy Panel, with, Amy Hardberger, Texas Tech Law School, November.

2011 Co-Host of Joseph Treaster, Woodrow Wilson Visiting Fellow with St. Edward's University Kozmetsky Center for Excellence in Global Finance.

2011 Co-Host of Dr. Diana Liverman, Oxford and University of Arizona with St. Edward's University Kozmetsky Center For Excellence in Global Finance.

2011 El Camino Real de los Tejas, Past \& Present, Austin Opening, "Hard Bottomed Fords on the La Bahia Road: Connecting the Dots," or “Early Development in Texas." St. Edward's University Kozmetsky Center for Excellence in Global Finance, Sponsored by the Consulate General of Spain, the National Parks Service Historic Trails Association, and The Texas Historical Commission. September 20.

2011 Guest Speaker for the San Marcos Board of Realtors at Water Rights Update Luncheon in conjunction with Karl Dreher, GM of the Edwards Aquifer Authority

2011 San Antonio Conservation Society, “Analysis of Daub Sample from Blas Herrera Colonial Period Jacal,” with Fran Gale, Director of the University of Texas Architectural Department Conservation Lab, September 17.

2011 Luncheon host and Emcee on Climate Change and Water in Texas with Dr. Diana Liverman of Oxford University including participants Mark Strama, Member of the Texas House of Representatives, Paul Workman, Member of the Texas House of Representatives, Dr. Patrick Cox, Board Member of the Pedernales Electric Co-Op in conjunction with the Kozmetsky Center for Excellence in Global Finance of St. Edward's University.

2011 International Right of Way Association, San Marcos, "The Impact of Private Water Pipelines on Right of Way Acquisition,” September 9.

2011 United States Geological Society Texas Water Science Center, San Antonio, “The Pivot Point for Texas Water Rights: San Antonio,” June 24.

2011 San Antonio Conservation Society, "Eyewitness Perspectives of a Village in Transition on the Far Frontier, San Antonio, 1810-1855, ’ June 4. 
2011 Lecturer at the Sons of the American Revolution, Austin Chapter, topic, “A Biographical Sketch of General Nathaniel Greene, George Washington's Favorite General (and my Great, Great, Great, Great, Great Grandfather)," April 16.

2011 Sole Lecturer - Austin Board of Realtors Managing Broker's Forum - “Negligence and Civil Liability: How the TREC Code of Ethics and the Occupations Code Link to Damages,” April.

2011 Water policy discussion with the Lt. Governor's General Counsel, Carmen Cernosek. March 27.

2011 Sole lecturer at Texas House of Representatives Member Paul Workman's “Water Rights and Texas (featuring water rights expert, Charles R. Porter, Jr.)" Invited guests - the Freshmen Members of the Texas House of Representatives, held March 9, 2011

2011 Acceptance Speech for Book Award, San Antonio Conservation Society, "The Financial Impact of the Work of the San Antonio Conservation Society,” March 25.

2011 Speaker at the Professional Tour Guides of San Antonio Spring Education series, topic, “The History of San Antonio Water Rights,” March 23.

2011 Speaker at the International Right of Way Association's luncheon speaker series in Austin, Texas, topic, "Right of Way in Texas Water and Real Estate: Perspectives from an Expert Witness,” March 8.

2011 Presenter at the World History Association of Texas Conference: Innovations in Teaching and Research, topic, “A Class Mediation Exercise for Understanding Global Water Disputes,” held February 19, 2011.

2011 Lecturer and organizer (with Texas House Representative Mark Strama) of a Primer of Water Rights for Representatives Miller, Lucio, Workman, and Strama, breakfast hosted by Charles Porter and held at the Austin Club February 16, 2011.

2011 Organizer/lecturer at the Historic Research Training Workshop, San Antonio Conservation Society, at the San Antonio Public Library, January 22, 2011 in San Antonio, Texas

2011 Keynote speaker at the Groundwater District Manager's Association (national trade association), held January 13, 2011 in San Antonio, Texas. The conference was named “Unintended Consequences” for Porter's presentation.

2011 Organizer/lecturer at the Oral History Training Workshop, San Antonio Conservation Society, at the River House, November 13, 2010, in San Antonio, Texas. 
2010 “Negligence and Civil Damages Risks for Broker Managers,” Realty Round Up, Austin, October.

2010 Poster presentation at the Teaching Excellence Showcase, St. Edward's University, "The World's First Ever 100 Word History Conference," August.

2010 Lecturer by invitation at the Edwards Aquifer Authority lunch speaker series in San Antonio, in the boardroom, topic, "Tales from the Common Pool: Unintended Consequences," August.

2010 Lecturer by invitation at the United States Geological Service lunch speaker series in Austin webcast statewide, topic, "Decisions and Consequences in the Common Pool," May.

2010 Lecturer by invitation at the Texas Alliance of Groundwater Districts' Quarterly Meeting in Austin, Texas, topic, "Unintended Consequences: A Trilogy of Tales From the Common Pool," March.

2010 Presenter at the MLA Symposium, MLA Alumni Meeting, topic, "Tales from the Common Pool: Values, Obligations, and Consequences,” April.

2010 Presenter at the World History Association of Texas Conference - "The Convergence and Divergence of Agricultural Ideas Between Spaniards and Jumano Indians Along the Rio Grande," February.

2010 Presenter and organizer of the panel at the Texas State Historical Association's Convention in Dallas, Texas, topic “The Beginnings of Spanish Settlement in the El Paso District Revisited," March.

2010 Presenter, by invitation, at the Adjunct Orientation for the Spring semester, St. Edward's University, January.

2010 Lecturer, by invitation, for all sections of American Experience, CULF 1320, St. Edward's University, University Programs, early-semester focus on colonizers to the New World, topic, "The First Missionaries in the New World: Saviors or Agents of Directed Cultural Change?” January.

2010 Lecturer for all American Experience students, St. Edward's University, "The First Missionaries in the New World: Saviors or Agents of Directed Cultural Change."

2010 Guest Lecturer in Freshman Studies, St. Edward's University, “Water: Unintended Consequences: Values, Obligations, and Consequences."

2010 Lecturer St. Edward's University Graduate School, Master of Liberal Arts, "Perspectives of Time," also in 2006, 2007, 2008, 2009, 2010, 2011,2012. 
2010 Lecturer St. Edward's University Graduate School, Master of Liberal Arts, “Americans, A Sense of Place," also in 2007, 2009.

2010 Lecturer in Ann Strong's “American Dilemmas," St. Edward's University, additionally in 2009, "Water: The Common Denominator."

2009 Lecturer in Steve Rodenborn's Religious Studies Class, St. Edward's University,

“The History of the First Missionary College in the New World, Querétaro."

2009 Lecturer at Blinn University, Undergraduate School of History, "Water in 19th Century Texas: Spanish Roots in Law and Practice.”

2009 Lecturer at six Water Workshops at St. Edward's University attended by $700+$ students and faculty over 4 months, fall 2009. The water workshops were required for all students to meet the requirements of Cultural Foundations in University Programs.

2009 Presenter at the World History Association of Texas Conference - "Spanish Roots in Texas Water Law: Three Hundred Years of Connections and Consequences.”

2009 Panelist and lecturer at the Austin Board of Realtors/Austin Home Builders Association Economic Forecast, 1,100 attendees

2008 Presenter at St. Edward's University MLA Symposium - “From Acequias to the San Antonio Water Company: Sharing and Managing Water in San Antonio from Colonial Bexar to the Gilded Age."

2007 Lecturer at Concordia University Undergraduate School for the "Ethical Dilemmas and Decisions in Criminal Justice."

2007 Lecturer St. Edward's University Business Graduate School, Master of Arts in Human Services, "My Experiences as a Chairman of the Board of Directors with Board Governance Policy Concepts.”

2007 Presenter and organizer at the Texas State Historical Association's convention session titled “Water Rights in Texas From the Gilded Age to Ike”, Dr. Paula Mitchell Marks, Chairman, along with Texas State Representative Mark Strama, presenter, and Dr. Thomas Glick, Boston University, presenter.

2007 Presenter and Emcee of the Most Worthy Citizen Award to Coach Jody Conradt of the University of Texas Women's Basketball Team. 


\section{Appendix 1}

\section{Focus Groups Held by Charles Porter (2016 only)}

$\begin{array}{lll}\text { Date } & \text { Participants } & \text { Topic } \\ \text { Feb. 16, } 2016 & \text { Jason T. Hill287 } & \text { Jurisprudence in Texas timeliness } \\ & \text { Timothy L. Brown }{ }^{28} & \text { Jurisprudence in Texas timeliness } \\ \text { May 10, } 2016 & \text { Carlos Rubinstein } 289 & \text { Interbasin water transfer } \\ & \text { Herman Settemeyer } 290 & \text { Interbasin water transfer } \\ \text { May 20, } 2016 & \text { Timothy L. Brown } & \text { Interbasin water transfer } \\ & \text { Edmond J. McCarthy, Jr.291 } & \text { Water fair market value }\end{array}$

${ }^{287}$ Jason T. Hill is a water law attorney in Austin, Texas. He has earned the ranking of Super Lawyer in Texas and Best Lawyers. He has extensive experience in representing clients in contested case hearings before the State Office of Administrative Hearings, the Railroad Commission of Texas, and many other political subdivisions.

${ }^{288}$ Tim Brown has practiced water law in Texas for over 40 years. His early career was with the Texas Water Rights Commission as one of the first regulatory agency officers for promulgation of the 1967 Texas Water Rights Adjudication Act. As the Texas Water Rights Commission morphed into the Texas Commission on Environmental Quality, Tim became General Counsel for the agency. He also served as a Texas Assistant Attorney General, as Chief of the Environmental Protection Division of the Texas Attorney General's Office. He has entered private practice with Sledge Law in Austin, Texas.

${ }^{289}$ Carlos Rubinstein is a licensed civil engineer, past Rio Grande Watermaster for the State of Texas, past Commissioner of the Texas Commission on Environmental Quality, past Chairman of the Texas Water Development Board and a leading expert in water law and permitting both at the state and federal levels. He is a partner in RSAH20 a consulting firm in Austin, Texas.

${ }^{290}$ Herman Settemeyer is a licensed professional engineer with 40 years of experience in water regulation in Texas working for the Texas Commission on Environmental Quality. He was the TCEQ representative in interstate rive compact administration, international treaty compliance officer, was involved in the adjudication of surface water rights in Texas under the 1967 Water Rights Adjudication Act, and permitted and enforced water rights and management policies in Texas. He is one of the foremost experts on Texas surface water permitting. He is a partner in RSAH20 a consulting firm in Austin, Texas.

${ }^{291}$ Ed McCarthy joined the Law Firm of Jackson, Sjoberg, McCarthy \& Wilson, L.L.P. as a Partner in May 2003. After graduating from St. Mary's Law School in May 1981, Ed served as a Briefing Attorney on the Supreme Court of Texas. During his tenure with the Court, Ed was assigned to former Texas Supreme Court Justices James Denton (deceased) and Ruby Kless Sondock. Following his service on the Court, Ed served as a Captain in the Judge Advocate General's Corps, United States Army. During his tour of active duty, Ed was a 


$\begin{array}{lll}\text { May 25, 2016 } & \text { Robert Mace } 292 & \text { Artesian pressure aquifers } \\ & \text { Timothy L. Brown } & \text { Artesian pressure aquifers } \\ \text { June 2, 2016 } & \text { Carlos Rubinstein } & \text { Water permits Texas } \\ & \text { Herman Settemeyer } & \text { Water permits Texas } \\ & \text { Timothy L. Brown } & \text { Water permits Texas } \\ \text { June 7, 2016 } & \text { Yuval Edrey }{ }^{293} & \\ & \text { Yael Glazer } & \\ & \text { Andrew Reimers } & \\ & & \text { Israel Palestine water }\end{array}$

member of the United States Army Government Appellate Division, and represented the United States in appellate matters before the United States Court of Military Appeals and the United States Army Court of Military Review. In 1985, Ed joined McGinnis, Lochridge \& Kilgore L.L.P., and became a Partner with the law firm in January 1989, where he practiced until 2003.

292 Dr. Robert E. Mace is the Deputy Executive Administrator of the Water Science and Conservation section of the Texas Water Development Board (TWDB). Dr. Mace leads a department of 70 scientists, engineers, and specialists dedicated to better understanding groundwater and surface water sources in Texas. He has been at the TWDB since 1999. Prior to working at the TWDB, Dr. Mace worked 9 years at the Bureau of Economic Geology at the University of Texas at Austin.

${ }^{293}$ Yuval Edrey is from Israel and a PhD candidate at the University of Texas at Austin College of Engineering.

${ }^{294}$ Yael Glazer is from Israel and a PhD candidate at the University of Texas at Austin College of Engineering.

295 Andrew Reimers is a Texan and a PhD candidate at the University of Texas at Austin College of Engineering. Andrew has been a coordinator for three years of the University of Texas Energy Week, a seminar about energy in Texas sponsored by the UT College of Engineering. He has special expertise in the water/energy nexus. 


\section{Appendix 2}

\section{A Brief Glossary of Other Water Related Terms}

Agriculture means any of the following activities:

(A) cultivating the soil to produce crops for human food, animal feed, or planting seed or for the production of fibers;

(B) the practice of floriculture, viticulture, silviculture, and horticulture, including the cultivation of plants in containers or non-soil media, by a nursery grower;

(C) raising, feeding, or keeping animals for breeding purposes or for the production of food or fiber, leather, pelts, or other tangible products having a commercial value;

(D) raising or keeping equine animals;

(E) wildlife management; and

(F) planting cover crops, including cover crops cultivated for transplantation, or leaving land idle for the purpose of participating in any governmental program or normal crop or livestock rotation procedure.

Agricultural use means any use or activity involving agriculture, including irrigation. 
Appropriator means a person who has made beneficial use of any water in a lawful manner under the provisions of any act of the legislature before the enactment of Chapter 171, General Laws, Acts of the 33rd Legislature, 1913, as amended, and who has filed with the state Board of Water Engineers a record of his appropriation as required by the 1913 Act, as amended, or a person who makes or has made beneficial use of any water within the limitations of a permit lawfully issued by the commission or one of its predecessors.

Appurtenant means belonging to; accessing or incident to; adjunct, appended, or annexed to.

Beneficial use means use of the amount of water that is economically necessary for a purpose authorized in Chapter 11 of the Texas Water Code, when reasonable intelligence and reasonable diligence are used in applying the water to that purpose and shall include conserved water. In Chapter 36 , "Use for a beneficial purpose" means use for (A) agricultural, gardening, domestic, stock raising, municipal, mining, manufacturing, industrial, commercial, recreational, or pleasure purposes; (B) exploring for, producing, handling, or treating oil, gas, sulphur, or other minerals; or 
(C) any other purpose that is useful and beneficial to the user.

Best management practices means those voluntary efficiency measures developed by the commission [TCEQ] that save a quantifiable amount of water, either directly or indirectly, and that can be implemented within a specified time frame.

Conjunctive means joined together, combined so that changes in one directly results in changes to the other.

Conjunctive use means the combined use of groundwater and surface water sources that optimizes the beneficial characteristics of each source.

Conservation means:

(A) the development of water resources; and

(B) those practices, techniques, and technologies that will reduce the consumption of water, reduce the loss or waste of water, improve the efficiency in the use of water, or increase the recycling and reuse of water so that a water supply is made available for future or alternative uses. 
Conserved water means that amount of water saved by a holder of an existing permit, certified filing, or certificate of adjudication through practices, techniques, and technologies that would otherwise be irretrievably lost to all consumptive beneficial uses arising from storage, transportation, distribution, or application.

Correlative means having a reciprocal relationship in that the existence of one relationship normally implies the existence of the other. In the law governing water rights in many western states but not Texas, the correlative rights doctrine gives the individual owners of land overlying a strata of percolating waters limited rights to use the water reasonably when there is not enough water to meet the needs of everyone in the area.

Evidence of historic or existing use means evidence that is material and relevant to a determination of the amount of groundwater beneficially used without waste by a permit applicant during the relevant time period set by district rule that regulates groundwater based on historic use. Evidence in the form of oral or written testimony shall be subject to cross-examination. The Texas Rules of Evidence govern the admissibility and introduction of evidence of 
historic or existing use, except that evidence not admissible under the Texas Rules of Evidence may be admitted if it is of the type commonly relied upon by reasonably prudent persons in the conduct of their affairs.

Groundwater means water percolating below the surface of the earth.

Groundwater reservoir means a specific subsurface waterbearing reservoir having ascertainable boundaries containing groundwater.

Managed or modeled available groundwater means the amount of water that may be permitted by a district for beneficial use in accordance with the desired future condition of the aquifer as determined under Section 36.108 of the Texas Water Code.

Priority groundwater management area means an area designated and delineated by the commission [TCEQ] under Chapter 35 of the Texas Water code as an area experiencing or expected to experience critical groundwater problems. 
Public water supply well means, for purposes of a district governed by Chapter 36, Texas Water Code, a well that produces the majority of its water for use by a public water system

Recharge means the amount of water that infiltrates to the water table of an aquifer.

Riparian means adjacency of land to a river, stream, or creek.

River basin means a river or coastal basin designated as a river basin under Section 16.051 of the Texas Water Code. The term does not include waters originating in the bays or arms of the Gulf of Mexico.

Subsidence means the lowering in elevation of the land surface caused by withdrawal of groundwater.

Total aquifer storage means the total calculated volume of groundwater that an aquifer is capable of producing. 
Waste means any one or more of the following:

(A) withdrawal of groundwater from a groundwater reservoir at a rate and in an amount that causes or threatens to cause intrusion into the reservoir of water unsuitable for agricultural, gardening, domestic, or stock raising purposes;

(B) the flowing or producing of wells from a groundwater reservoir if the water produced is not used for a beneficial purpose;

(C) escape of groundwater from a groundwater reservoir to any other reservoir or geologic strata that does not contain groundwater;

(D) pollution or harmful alteration of groundwater in a groundwater reservoir by saltwater or by other deleterious matter admitted from another stratum or from the surface of the ground;

(E) willully or negligently causing, suffering, or allowing groundwater to escape into any river, creek, natural watercourse, depression, lake, reservoir, drain, sewer, street, highway, road, or road ditch, or onto any land other than that of the owner of the well unless such discharge is authorized by permit, rule, or order issued by the commission under Chapter 26;

(F) groundwater pumped for irrigation that escapes as irrigation tailwater onto land other than that of the 
owner of the well unless permission has been granted by the occupant of the land receiving the discharge; or

(G) for water produced from an artesian well, "waste" has the meaning assigned by Section 11.205.

Water right means a right acquired under the laws of this state to impound, divert, or use state water. A more thorough definition of a "water right" is a right or group of rights designed to protect the use, enjoyment, and in some cases, ownership of water that travels in streams, rivers, lakes, and ponds, gathers on the surface of the earth, or collects underground 


\section{Appendix 3}

\section{Proof of the Originality Porter's Conclusions on the Consequences of the Save Our Springs Ordinance for Ad Valorem Tax Revenues}

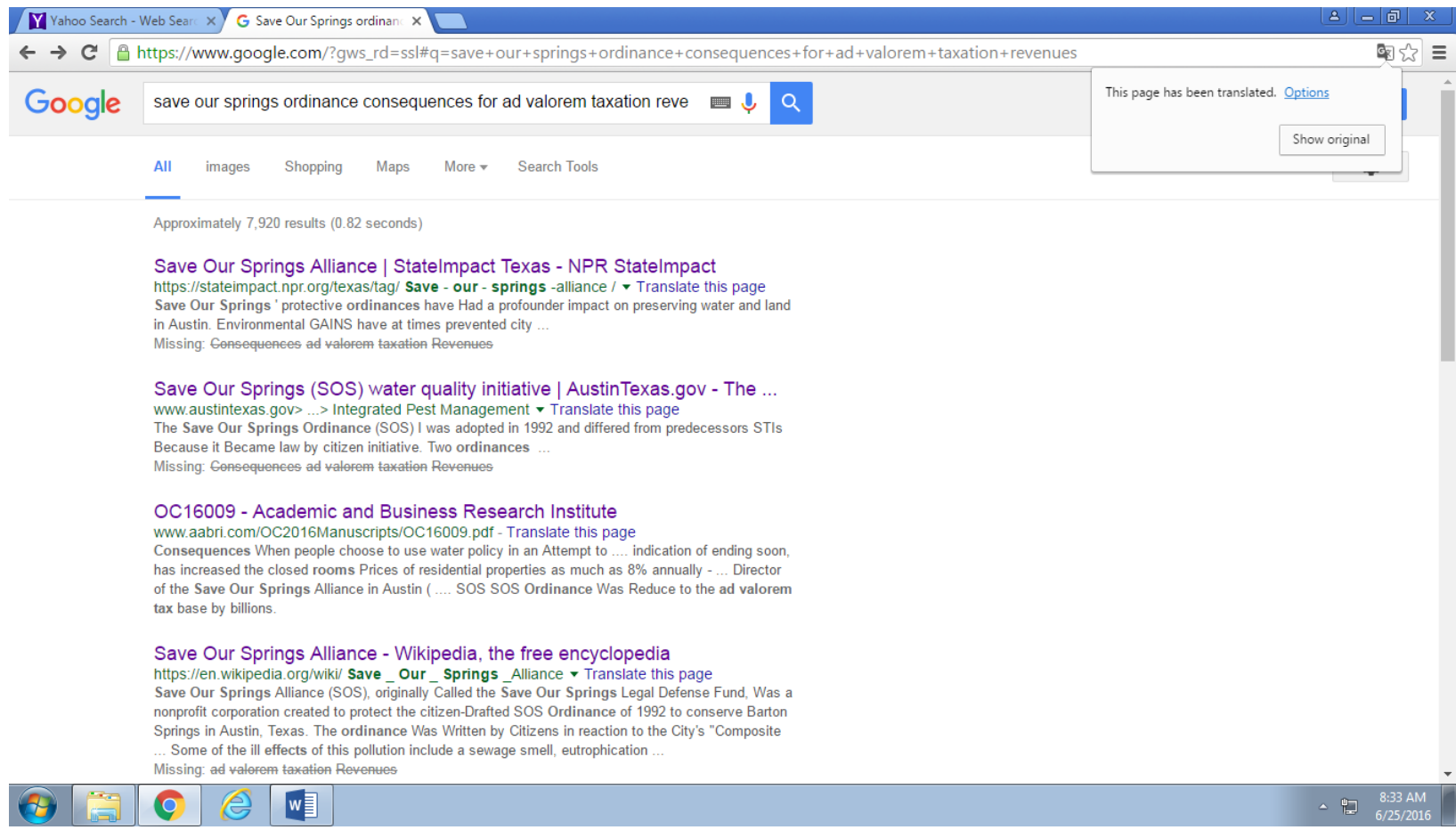

Google only search for consequences of Save Our Springs Ordinance - see the only academic article ever written is mine Oc16009 in the Academic and Business Research Institute Orlando Conference Papers 


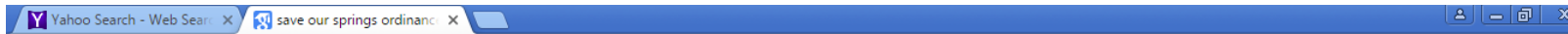

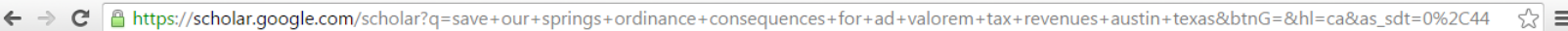
Web Imatges Més... Entra

Google save our springs ordinance consequences for ad valorem tax revenues aust $-\quad$ a

Acadèmic $\quad$ Aproximadament 186 resultats $(0,09 \mathrm{~s})$

Les meves cites

Articles Consell: Cerca només resultats en català . Podeu especificar lídioma de cerca a Configuració de Google Acadèmic

La meva biblioteca Preserving biodiversity: challenges for planners

T Beatley - Journal of the American Planning Association, 2000 - Taylor \& Francis

... black-tailed prairie dog. currently under consideration for federal listing as a consequence of

En qualsevol moment precipitous ... that it's hurting not only the salmon but the health of our whole region.... areas oth- erwise

Des de 2016 protected (ie, areas off limits under the City's comprehensive watersheds ordinance)....

Citat per 142 Articles relacionats Cita Desa Més

Des de 2012 On empire's shore: free and unfree workers in Galveston, Texas, 1840-1860

... he became trapped in a sunken vessel despite the efforts of several slaves and other white men

a.lso wocking the salvage to save him. ... Many of our most prominent .... Refine results with the filtering
Ordena per rellevància options on the left side of the Advanced Search page or on your search results page ...

Ordena per data

Aer 2 Articles relacionats Totes les 11 versions Cita Desa

Potential barriers to affordable housing for immigration of lower-income residents in land use $\quad$ [PDF] de utexas.edu

$\checkmark$ patents incloses plans of suburban towns in the Austin MSA

$\checkmark$ inclou cites JA Carrillo - 2015 - repositories lib. utexas edu

... matching rental supply and demand, and also states that "the old axiom in the rental business

is if you've hit 95 percent you should be raising your rents" (Austin American-... land use regulation

$\begin{array}{ll}\square \text { Crea una alerta } & \text { and its negative effects on housing, "Not in My Back Y } \\ \text { Articles relacionats Totes les } 3 \text { versions Cita Desa }\end{array}$

[LLIBRE] A Financial History of Texas

ET Miller - 1916 - books google.com

[HTML] de google.com

In theision of the customs law was done primarily to safeguard the col- 'Ordinances and Decrees ...

ordinance was entitled an 'Ordinance and decree for the better accommodation of the ...

Citat per 51 Articles relacionats Totes les 6 versions Cita Desa Més

[PDF] de csuohio edu

Google Scholar - none.

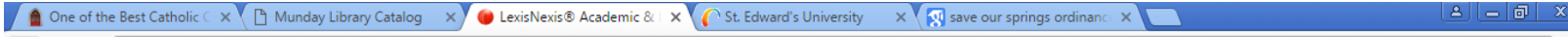

$\leftarrow \rightarrow C$ Cww.lexisnexis.com.ezproxy.stedwards.edu/hottopics/nacademic/

Use of this service is subject to Terms and Conditions

Source Directory: Find or Browse | Create Permanent Link | Help

Results List | Edit Search | New Search | Home

LexisNexis ${ }^{\circledR}$ Academic

Results Web News

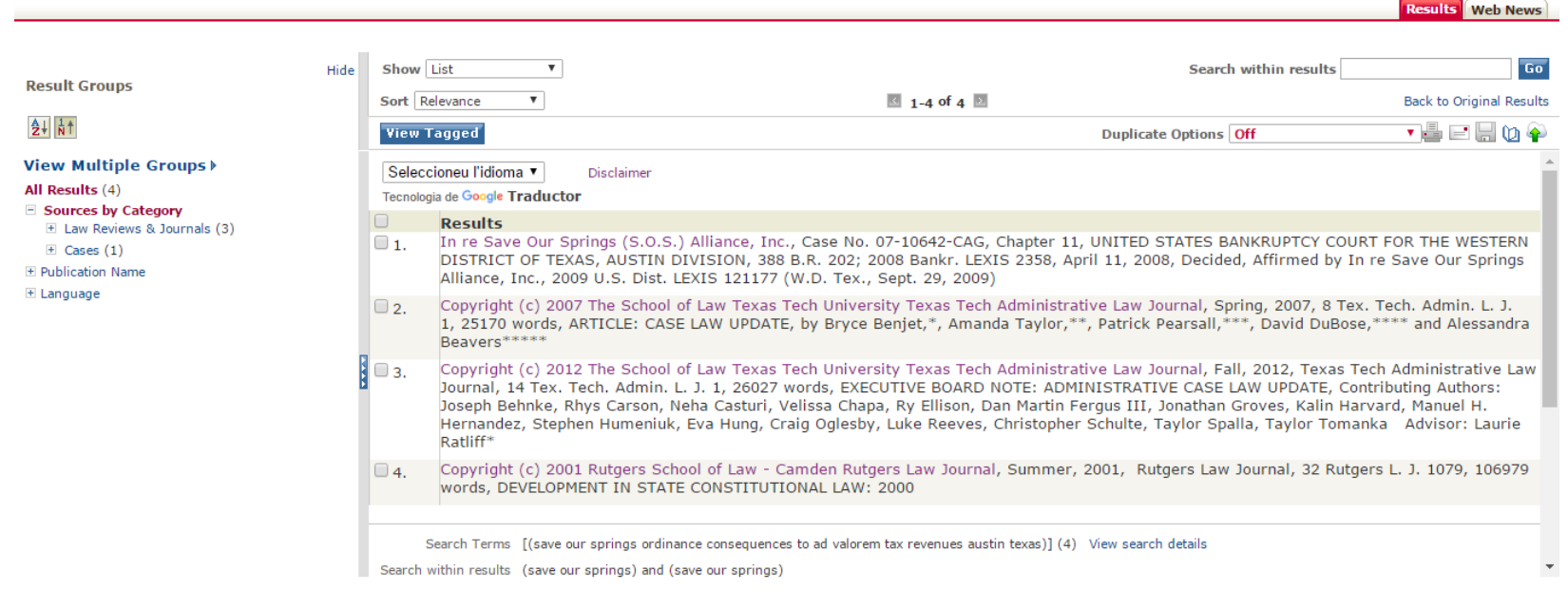




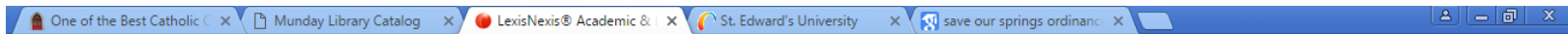

$\leftarrow \rightarrow \mathrm{C} \square$ www.lexisnexis.com.ezproxy.stedwards.edu/hottopics/Inacademic/

Use of this service is subject to Terms and Conditions

Source Directory: Find or Browse | Create Permanent Link | Help

LexisNexis ${ }^{\circledast}$ Academic

Academic Searcl

Search by Subject or Topic $\nabla$

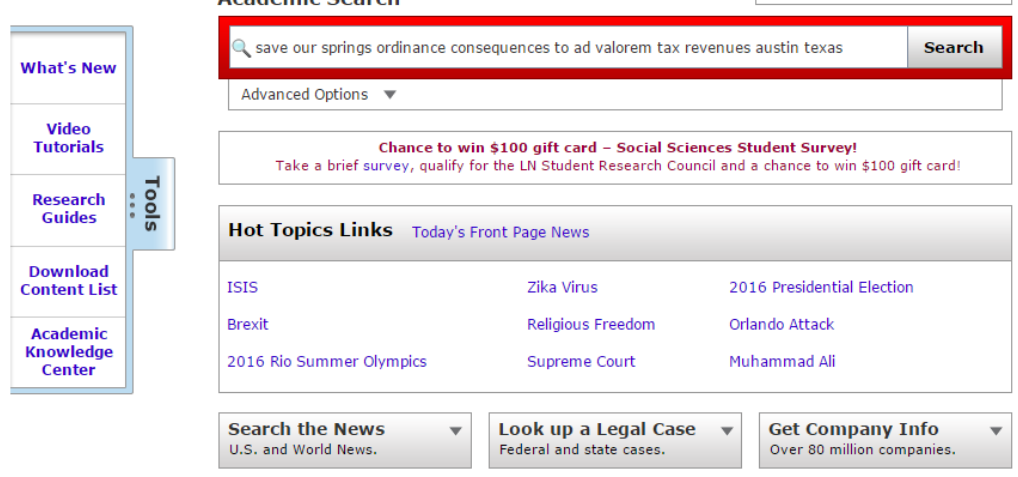

(2)

Lexis Nexis Search yielded 4 articles, none of which have any financial analysis of the save Our springs ordinance. 


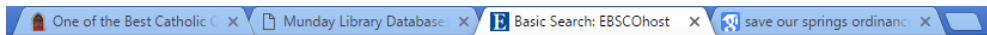

$\leftarrow \rightarrow \mathrm{C}$ [ web.a.ebscohost.com.ezproxy.stedwards.edu/ehost/search/basic?sid=29b8caf0-7c1f-4827-866d-ee72d9da3486\%40sessionmgr4005\&vid=2\&hid=4107

EBSCO Academic Search Complete yielded no articles at all about the Save Our Springs Ordinance.

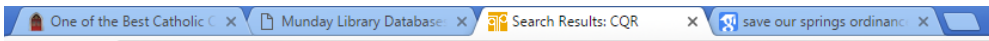

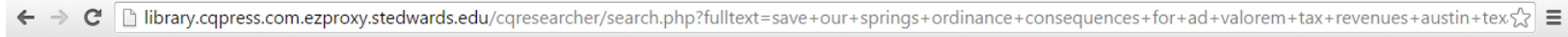

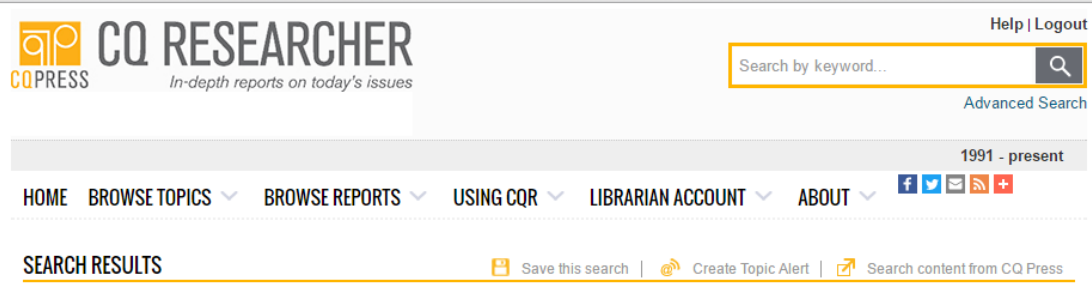

Results for save our springs ordinance consequences for ad valorem tax revenues austin texas

We're sorry, no documents were found to match your criteria.

Feedback | Suggest a Topic | Voluntary Product Accessibiity Template @ | General Terms of Service | Copyright Notice and Takedown Policy | Masthead | Privacy Polic

(92016, CQ Press, An Imprint of SAGE Publications. All Rights Reserved. CQ Press is a registered trademark of Congressional Quarterly Inc.

(4)

CQ Researcher yielded no articles at all about the Save Our Springs Ordinance. 


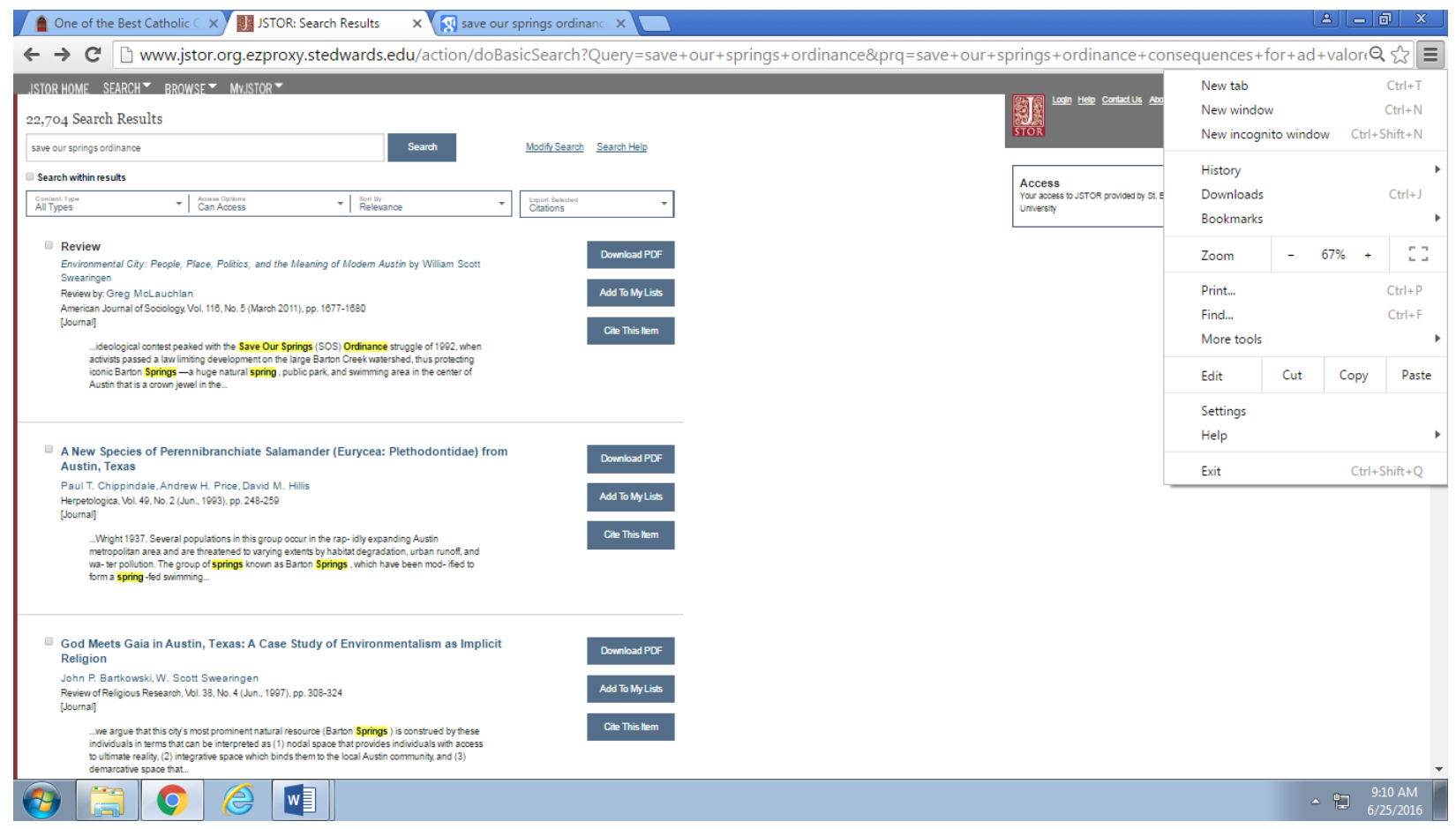

JSTOR yielded 3 articles, none of which have any financial analysis of the Save Our Springs Ordinance. 
国 Basic Search: EBSCOhost $\times \square$

$\leftarrow \rightarrow$ C [web.b.ebscohost.com.ezproxy.stedwards.edu/ehost/search/basic?sid=e660591b-cd8c-4885-9e03-1dbcba8fa1bc\%40sessionmgr120\&vid =3\&hid=107

Searching: ERIC | Choose Databases

save our springs austin $\quad \times$ Search

EBSCOhost Search Options • Basic Search Advanced Search Search History

No results were found.

EBSCO ERIC yielded no articles at all about the save our Springs Ordinance. 


\section{Academic and Business Research Institute}

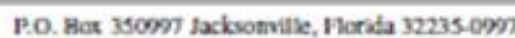

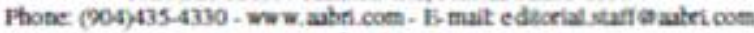

De. Rusvell Raher, Execulive Difocticr

May 23, 2016

Charks Ponet

St Edwand's University

Re: Manuseript 162390

Dear Dr. Ponter,

Congratulations, baxed ce peer review and editorial review to verify complianoe with submission requirements, your manuscript entitled "Public Wave Policies The Ultimate Weapons of Social Control" has been acoepted for publication in the Research in Bwiness and Economics Journal.

Throagh submission of the manuscript for nview you grant the Academic and Buxiness Research Institule (AABRD) permission to publist the manuscript and place it on cur website. Submission of your manascript also centifies that the document is your (and your coauthors") original work and has not boen peviously copyrighted (a clating cived quotations) or, if copyrighved, the submitter has penmission to mpublish. As a condition of acoeptance of a submission in contideration for poblication in an AABRI journal, all submitting athors agree to become reviewen on two manuscripts submitted by other authors for publicatice consideration. Please complete and submit the Reviewer Information Form if you have not

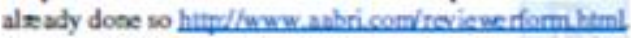

Congratalations again on the scoeptance of your manuscript for publicrion. Receipt of this letter indicanes that the manuscript has been pablished ce our website ww wabri com. Please eamine your manuscript. Feel free to notify your colleagues and friends of your successful publication.

Thank you for selecting the Academic and Business Rexearch hatituke and the Reseurch in Busines and Economics Joornal as publishing partnen for your nexarch endeavor.

Regands,

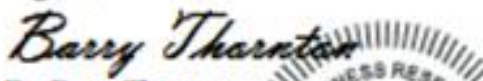

Dr. Barry Thomton

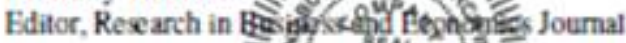

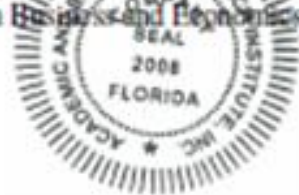

Approval letter for publication of the only peer-reviewed academic journal article, written by the author of this study that includes the analysis of the consequences of the sos 
Ordinance on ad valorem tax revenues. The article appeared in the journal on June 1, 2016. 